\title{
Tectonic Studies of the Berkshire Massif, Western Massachusetts, Connecticut, and Vermont
}
A. Blastomylonites Associated With Recumbent Folds and Overthrusts at the Western Edge of the Berkshire Massif, Connecticut and Massachusetts-A Preliminary Report
B. Chronology of Paleozoic Tectonic and Thermal Metamorphic Events in Ordovician, Cambrian, and Precambrian Rocks at the North End of the Berkshire Massif
C. Tectonic and Metamorphic Chronology of the Devonian and Silurian Rocks in the Guilford Dome Area, Southeastern Vermont
D. Tectonic, Metamorphic, and Intrusive History of Part of the East Side of the Berkshire Massif, Massachusetts
E. Recumbent Folding of the Goshen and Waits River Formations, Western Massachusetts
F. Time and Space Relationships of Structures Associated With the Domes of Southwestern Massachusetts and Western Connecticut
G. Minor Folds and Derived Orientations of Strain in the East Flank of the Berkshire Massif, Massachusetts

GEOLOGICAL SURVEY PROFESSIONAL PAPER 888

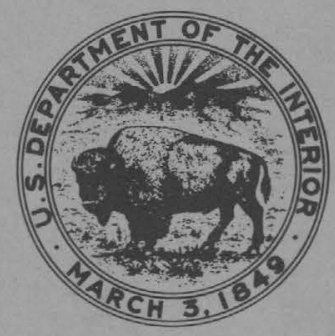





\section{Tectonic Studies of the Berkshire Massif, Western Massachusetts, Connecticut, and Vermont}

A. Blastomylonites Associated With Recumbent Folds and Overthrusts at the Western Edge of the Berkshire Massif, Connecticut and Massachusetts-A Preliminary Report, by Nicholas M. Ratcliffe and David S. Harwood

B. Chronology of Paleozoic Tectonic and Thermal Metamorphic Events in Ordovician, Cambrian, and Precambrian Rocks at the North End of the Berkshire Massif, Massachusetts, by Stephen A. Norton

C. Tectonic and Metamorphic Chronology of the Devonian and Silurian Rocks in the Guilford Dome Area, Southeastern Vermont, by J. Christopher Hepburn

D. Tectonic, Metamorphic, and Intrusive History of Part of the East Side of the Berkshire Massif, Massachusetts, by Norman L. Hatch, Jr.

E. Recumbent Folding of the Goshen and Waits River Formations, Western Massachusetts, by Philip H. Osberg

F. Time and Space Relationships of Structures Associated with the Domes of Southwestern Massachusetts and Western Connecticut, by Rolfe S. Stanley

G. Minor Folds and Derived Orientations of Strain in the East Flank of the Berkshire Massif, Massachusetts, by Philip S. Osberg

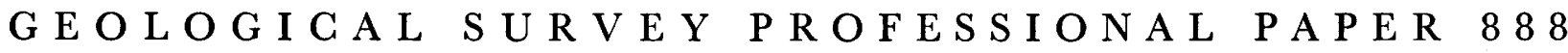




\title{
UNITED STATES DEPARTMENT OF THE INTERIOR \\ STANLEY K. HATHAWAY, Secretary
}

\author{
GEOLOGICAL SURVEY
}

\author{
V. E. McKelvey, Director
}

Library of Congress Cataloging in Publication Data

Main entry under title:

Tectonic studies of the Berkshire massif, western Massachusetts, Connecticut, and Vermont.

(Geological Survey professional paper ; 888) CONTENTS: Ratcliffe, N. M. and Harwood, D. S. Blastomylonites associated with recumbent folds and overthrusts at the western edge of the Berkshire massif, Connecticut and Massachusetts.-Norton, S. A. Chronology of Paleozoic tectonic and thermal metamorphic events in Ordovician, Cambrian, and Precambrian rocks at the north end of the Berkshire massif, Massachusetts. [etc.]

Includes bibliographies and index.

Supt. of Docs. no.: I 19.16:888

1. Geology-New England. 2. Berkshire Hills, Mass. I. Series: United States. Geological Survey. Professional paper ; 888 .

QE78.3.T4 $\quad 551.8^{\prime} 09744^{\prime} 1 \quad 74-23837$

For sale by the Superintendent of Documents, U.S. Government Printing Office

Washington, D.C. 20402

Stock Number 024-001-02695-3 


\section{CONTENTS}

(A) Blastomylonites associated with recumbent folds and overthrusts at the western edge of the Berkshire massif, Connecticut and Massachusetts-a preliminary report, by Nicholas M. Ratcliffe and David S. Harwood

Chronology of Paleozoic tectonic and thermal metamorphic events in Ordovician, Cambrian, and Precambrian rocks at the north end of the Berkshire massif, Massachusetts, by Stephen A. Norton

(C) Tectonic and metamorphic chronology of the Devonian and Silurian rocks in the Guilford dome area, southeastern Vermont, by J. Christopher Hepburn--

(D) Tectonic, metamorphic, and intrusive history of part of the east side of the Berkshire massif, Massachusetts, by Norman L. Hatch, Jr.

(E) Recumbent folding of the Goshen and Waits River Formations, western Massachusetts, by Philip H. Osberg

(F) Time and space relationships of structures associated with the domes of southwestern Massachusetts and western Connecticut, by Rolfe S. Stanley --

(G) Minor folds and derived orientations of strain in the east flank of the Berk shire massif, Massachusetts, by Philip H. Osberg -

Index -1-1- 



\section{Blastomylonites Associated with Recumbent Folds and Overthrusts at the Western Edge of the Berkshire Massif, Connecticut and Massachusetts- a Preliminary Report}

By NICHOLAS M. RATCLIFFE and DAVID S. HARWOOD

TECTONIC STUDIES OF THE BERKSHIRE MASSIF, WESTERN MASSACHUSETTS, CONNECTICUT, AND VERMONT

GEOLOGICAL S URVEY PROFESSIONAL PAPER $888-$ A

Prepared in cooperation with the Commonwealth of Massachusetts

Department of Public Works and the State of Connecticut

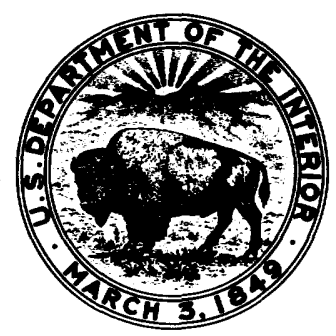

Geological and Natural History Survey 



\section{CONTENTS}

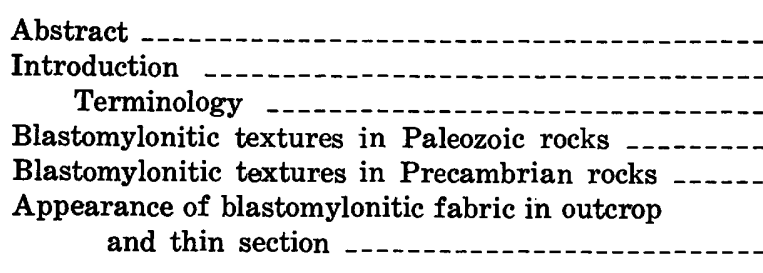
Page
Spatial relationship of cataclastic structures, recumbent folds, and major faults

\section{ILLUSTRATIONS}

1. Generalized geologic map of west edge of the Berkshire massif, southwestern Massachusetts and northwestern Connecticut

2. Major tectonic features and deformational events in the Berkshire massif

3. Classification of cataclastic rocks

4-6. Photographs showing:

4. Blastomylonitic foliation in Dalton Formation.

5. Highly folded and sheared Dalton Formation

6. Fine-grained mylonite schist of the Dalton Formation

7-12. Photomicrographs showing:

7. Mylonite schist of figure 6

8. Mylonite schist of the Walloomsac Formation

9. Single muscovite button in mylonite schist of Walloomsac Formation

10. Bent and sheared muscovite in Dalton Formation

11. Walloomsac Formation at leading edge of Lake Buel slice

12. Garnet of figure 11 rotated in blastomylonitic foliation

13-19. Photographs showing:

13. Biotite-ferrohastingsite granite gneiss above Beartown Mountain thrust

14. Cataclastically deformed granite gneiss _.

15. Mylonite gneiss with porphyroclasts of granite gneiss from low-angle fault zone -.......-

16. Blastomylonite seams in deformed Precambrian gneiss

17. Highly sheared mylonite gneiss from Beartown Mountain slice -

18. Recumbent antiform outlined by Precambrian gneissosity in biotite-ferrohastingsite granite gneiss -

19. Tightly appressed isoclines in Precambrian foliation

20. Geologic map and cross section showing the northwestern part of the South Sandisfield quadrangle --

21. Photographs of Tyringham Gneiss above thrust fault.

22. Photographs of blastomylonite with prophyroclastic augen of partly recrystallized Tyringham Gneiss --

5 



\title{
BLASTOMYLONITES ASSOCIATED WITH RECUMBENT FOLDS AND OVERTHRUSTS AT THE WESTERN EDGE OF THE BERKSHIRE MASSIF, CONNECTICUT AND MASSACHUSETTS- A PRELIMINARY REPORT
}

\author{
By Nicholas M. Ratcliffe ${ }^{1}$ and David S. Harwood
}

\begin{abstract}
The western edge of the Berkshire massif in western Massachusetts consists of imbricate thrust slices of recumbently folded Precambrian gneiss and unconformable Lower Cambrian and upper Precambrian(?) metasedimentary cover rocks, which were thrust southwestward over relatively autochthonous metasedimentary Upper(?) and Middle Ordovician to Lower Cambrian rocks. Deformation associated with thrust faulting produced distinct zones of cataclasis and recrystallization adjacent to the thrusts. Recumbent folds, spatially related to the thrust faults and ranging in wavelength from centimetres to hundreds of metres, formed contemporaneously with the thrust faulting and the cataclasis.

Rocks from fault zones are mylonite gneiss and mylonite schist that contain crosscutting seams of blastomylonite a few millimetres to tens of metres thick oriented subparallel to the axial planes of minor folds and to the faults.

On the basis of the superposition of minor structural features, the thrust-related fabric postdated a period of metamorphism and at least two and possibly three folding events in the early Paleozoic but preceded high-grade Barrovian metamorphism of probable Middle to Late Devonian age. Preliminary isotopic age studies of zircon from a granite stock that crosscuts one of the basement faults and the blastomylonitic fault fabric indicate the granite is Late Ordovician in age. These data indicate that the basement thrusting and preceding deformational events may be largely results of Taconic deformation.
\end{abstract}

\section{INTRODUCTION}

The western edge of the Berkshire massif in western Massachusetts consists of imbricate thrust slices of recumbently folded Precambrian gneiss and unconformable Lower Cambrian and Upper Precambrian metasedimentary cover rocks, the Dalton Formation and Cheshire Quartzite. Upper(?) and Middle Ordivician to Lower Cambrian miogeosyn-

\footnotetext{
${ }^{1}$ City College of New York, New York, N.Y.
}

clinal metasedimentary rocks that crop out in the Stockbridge Valley were metamorphosed and deformed prior to overthrusting of the basement rocks (Ratcliffe, 1969a). The contact between the overriding Berkshire massif and the underlying "autochthonous" metasedimentary rocks is a zone of imbricate faulting and concentrated recumbent folding; within the area of figure 1 approximately nine major thrusts sheets are now recognized. The thrust slices overlap one another towards the northeast; thus higher tectonic levels are exposed to the north than to the south.

This compilation is based on completed detailed mapping at $1: 24,000$ by Harwood in the South Sandisfield quadrangle and by Ratcliffe in the East Lee, Monterey, Ashley Falls, Great Barrington, and Stockbridge quadrangles. Preliminary data were reported previously by Ratcliffe (1969a), Ratcliffe and Harwood (1971), and Harwood (1971, 1972).

Harwood $(1971,1972)$ has shown the basement gneisses of the South Sandisfield quadrangle are recumbently folded in southwest-facing folds that are sheared out along their limbs to produce imbricated fault slices (see fig. 20). Similar structures are reported from the Windsor quadrangle (Norton, 1969) and from the Pittsfield East quadrangle (Alavi, 1971). In the Stockbridge, Great Barrington, Monterey, and Ashley Falls quadrangles (Ratcliffe, 1969a, and 1975a and b), the Beartown Mountain slice and the outliers of Monument and East Mountains form a large west-facing nappe cored by Precambrian gneiss. The brow region of this nappe, exposed in Monument and East Mountains, contains recumbently folded Dalto Formation and Cheshire 


\section{EXPLANATION}

$$
\approx 8
$$

Post-thrust granite

$$
\longrightarrow^{a}
$$

Pods of alaskite in faults

Rock has weakly developed blastomylonitic foliation. Occurrences north of Massachusetts

Turnpike contain crosscutting seams of magnetite and magnetite-rich alaskite

\section{ROCKS FOUND BENEATH THRUST FAULTS OF BERKSHIRE MASSIF}

Rocks of the Dalton Formation, Cheshire Quartzite, Stockbridge and Walloomsac Formations, as parautochthonous slices or "autochthonous" rock beneath Berkshire massif. Unit contains allochthonous rocks of the Everett Formation in the northwest

\section{ROCKS OF BERKSHIRE MASSIF}

Muscovite, biotite, staurolite, quartz or muscovite, biotite, sillimanite schists of June Mountain and Canaan Mountain in thrust contact with other rocks

\section{EpEdc}

Dalton Formation and Cheshire Quartzite (unconformable cover rocks of the Berkshire massif)

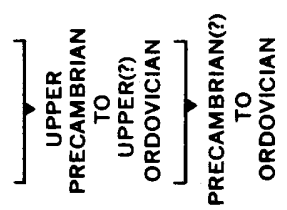

\section{UNCONFORMITY}

$$
\text { pes }
$$

Biotite, hornblende, quartz paragneiss, granitic gneiss, calc-silicate rocks, and amphibolite composing the crystalline rocks of the Berkshire massif

\section{Contact}

$$
\longrightarrow
$$

Synmetamorphic thrust fault formed during thrusting of Berkshire massif. Sawteeth on upper plate

Low-angle synmetamorphic thrust fault of metamorphic "eugeosynclinal" rocks thrust westward during emplacement of the Berkshire massif. Sawteeth on upper plate

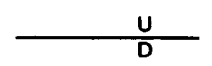

Postmetamorphic high-angle fault; U, upthrown side, D, downthrown side

Approximate location of isograd in Barrovian zonation, probably Acadian, postdating emplacement of Berkshire massif

$$
25-70
$$

Strike and dip of folded blastomylonitic foliation in zone where particularly well developed.

Formed during overthrusting of Berkshire massif, inclined, overturned. Symbol is

diagrammatic and applies to rocks above as well as beneath thrusts
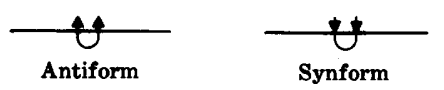

Axial trace and direction of plunge of overturned fold formed during thrusting of Berkshire massif $F_{3}$ folds of figure 2
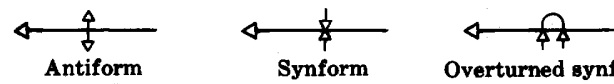

Overturned synform

Axial trace and direction of plunge of first major postthrust folds, with axial surface slip or crenulation cleavage. $\mathrm{F}_{4}$ folds of figare 2

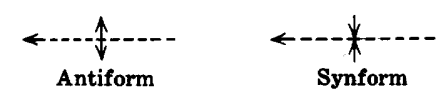

Axial trace and direction of plunge of second major postthrust fold, with axial planar slip or crenulation cleavage. $F_{5}$ folds of figure 2

$$
\times 5 A, B
$$

Collection

Locality of specimen figured in text 


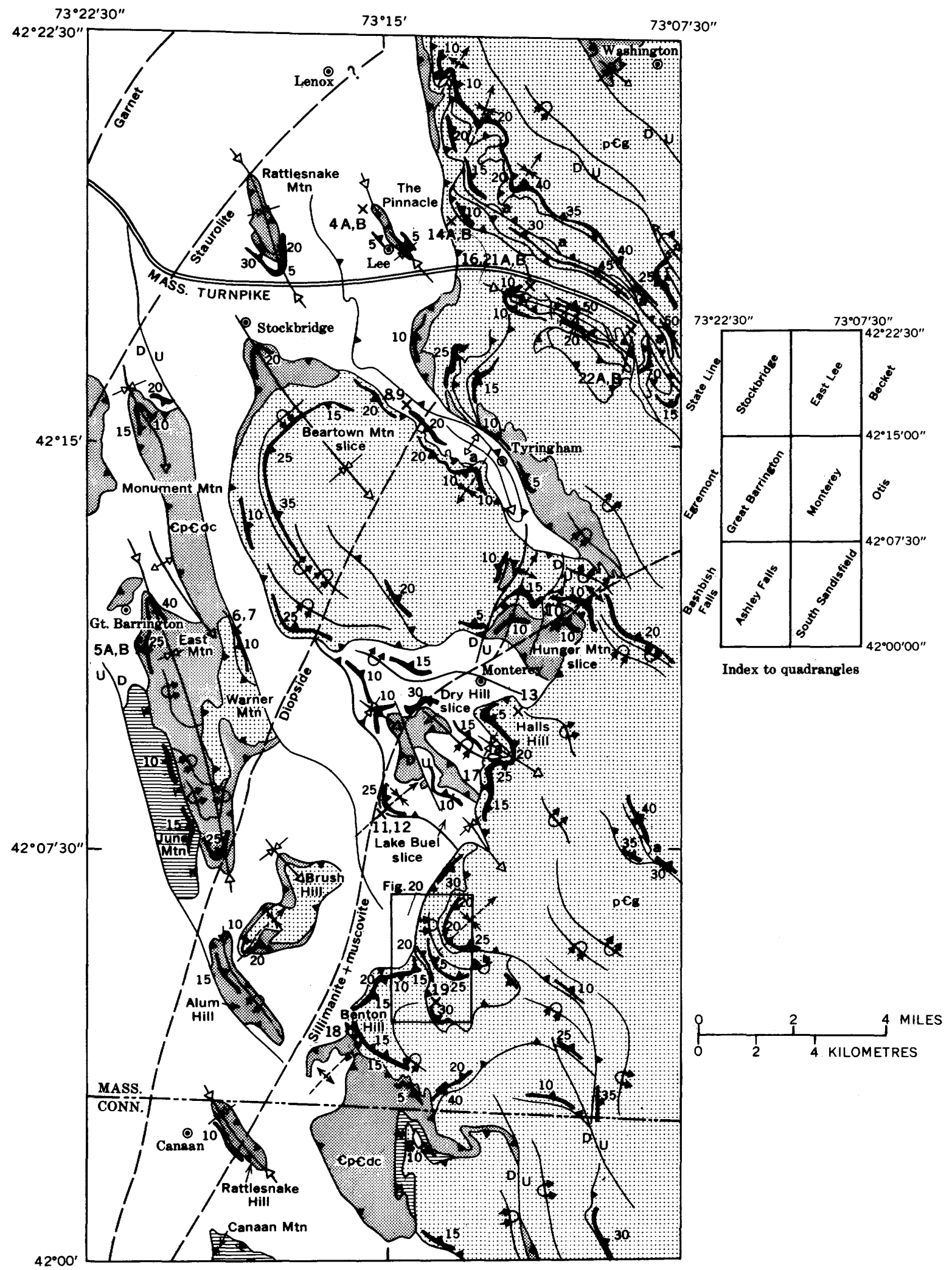

FIGURE 1.-Generalized geologic map of the west edge of the Berkshire massif, southwestern Massachusetts and northwestern Connecticut, showing major features associated with thrust faulting of the Berkshire massif. 
Quartzite in digitations of 2,200-m (7,000-ft) amplitude (Ratcliffe, 1975a and b). The Beartown Mountain slice, including the Monument Mountain and East Mountain outliers, rests discordantly on highly folded rocks of the Stockbridge Formation (Lower Ordovician to Lower Cambrian) and Walloomsac Formation (Upper(?) and Middle Ordovician) and overlaps these rocks for a distance of $21 \mathrm{~km}$ (13 miles) in an east-west direction.

On the basis of recent mapping, it seems likely that the overthrusts at the western edge of the Berkshire massif formed during a period of basement remobilization in which recumbent folds in the upwelling basement failed by shearing along the limbs of these folds to produce the fault slices. This tectonic style is characteristic of the entire area shown in figure 1; the traces and dip directions of the axial surfaces of overturned to recumbent folds believed to be associated with the overthrusting event are identified on figure 1. A majority of these fold traces trend northwest and dip to the northeast. Although the direction of overthrusting is not known at present, the sense of overturning and the observed overlapping of thrust slices northeastward suggests thrusting toward the southwest (Ratcliffe, 1969a).

Along the sole of the Beartown Mountain slice, and other slices as well, a distinctive fault fabric is developed. Both Precambrian and Paleozoic rocks within about $150 \mathrm{~m} \mathrm{(500} \mathrm{ft)} \mathrm{of} \mathrm{the} \mathrm{thrusts} \mathrm{contain}$ isoclinal intrafolial strain-slip folds whose axial surfaces are marked by a penetrative cataclastic metamorphic foliation and minor shear zones subparallel to the soles of the observed thrusts. The intensity of both the folding and shearing increases nearer faults.

In Precambrian rocks this fabric overprints the Precambrian gneissic layering (gneissosity) and a well-developed $b$ (fold axis) lineation. Paleozoic rocks, both in the thrust slices and beneath them, also exhibit the same cataclastic-metamorphic foliation and isoclinal folding as the Precambrian gneisses, but, importantly, the thrust fabric is superposed on preexisting Paleozoic axial-plane foliation.

The fault fabric, first recognized in 1968 in the excellent exposures at Benton Hill, Ashley Falls quadrangle, has been mapped throughout the area of figure 1. The fabric is uniquely associated with the boundaries of fault slices that are recognizable in most cases by independent criteria such as truncation of units against the thrusts.

The purpose of this chapter is to present descriptions of the fabrics associated with these overthrusts and to establish the position of these features in the sequence of tectonic events now recognized in the area of the Berkshire massif (fig. 2). As can be seen from figure 1 , the thrusts have been folded and locally the faults are overturned. The postthrust deformation coincided approximately with high-grade regional metamporphism of sillimanite grade.

The geologic history of this area is extremely complex, and the map (fig. 1) is grossly oversimplified in order to emphasize the faults and their associated features.

\section{TERMINOLOGY}

The terminology for the cataclastic rocks follows that of Higgins (1971) (fig. 3). Most rocks associated with the overthrusts described here belong to the series mylonite schist, mylonite gneiss, or blastomylonite.

Mylonite gneiss (mylonite schist) is defined by Higgins (1971, p. 75) as: "A coherent rock intermediate between a protomylonite or coarse mylonite and a crystalline gneiss or schist because its texture is the result of combined cataclastic [granulation] and crystalloblastic processes [recrystallization and (or) neomineralization]."

Both mylonite gneiss and mylonite schist contain greater than 30 percent porphyroclasts (fig. 3), and most of these porphyroclasts are greater than 0.2 $\mathrm{mm}$ in size. Blastomylonite, however, contains less than 30 percent porphyroclasts, and these are less than $0.5 \mathrm{~mm}$ in size.

The grain size of the recrystallized minerals does not enter into this classification. Thus a blastomylonite could range from a phyllite to a coarsely schistose rock. Where coarsely schistose rock is the final product, neomineralization or recrystallization was more important than and outlasted or postdated the cataclastic processes (Higgins, 1971, p. 13, fig. 13). These rocks can simply be termed coarsely schistose blastomylonites.

The "cataclastic-mylonitic" rocks associated with the overthrusts described here rarely are wholly blastomylonite according to the definition above. Instead, zones affected by cataclasis and recrystallization are spaced through the rocks. At the scale of a hand specimen most rocks are mylonite gneiss or mylonite schist with varying amounts of porphyroclasts. In the mylonite gneiss, fine zones of cataclasis, 0.5 to $5 \mathrm{~mm}$ thick, are themselves composed of finely crushed and recrystallized material with a preferred crystalloblastic structure and thus the zones meet the above definition of blastomylonite.

In outcrops, dark zones of highly sheared rock 1 cm to several metres thick cut through structures 
TECTONIC STUDIES OF THE BERKSHIRE MASSIF

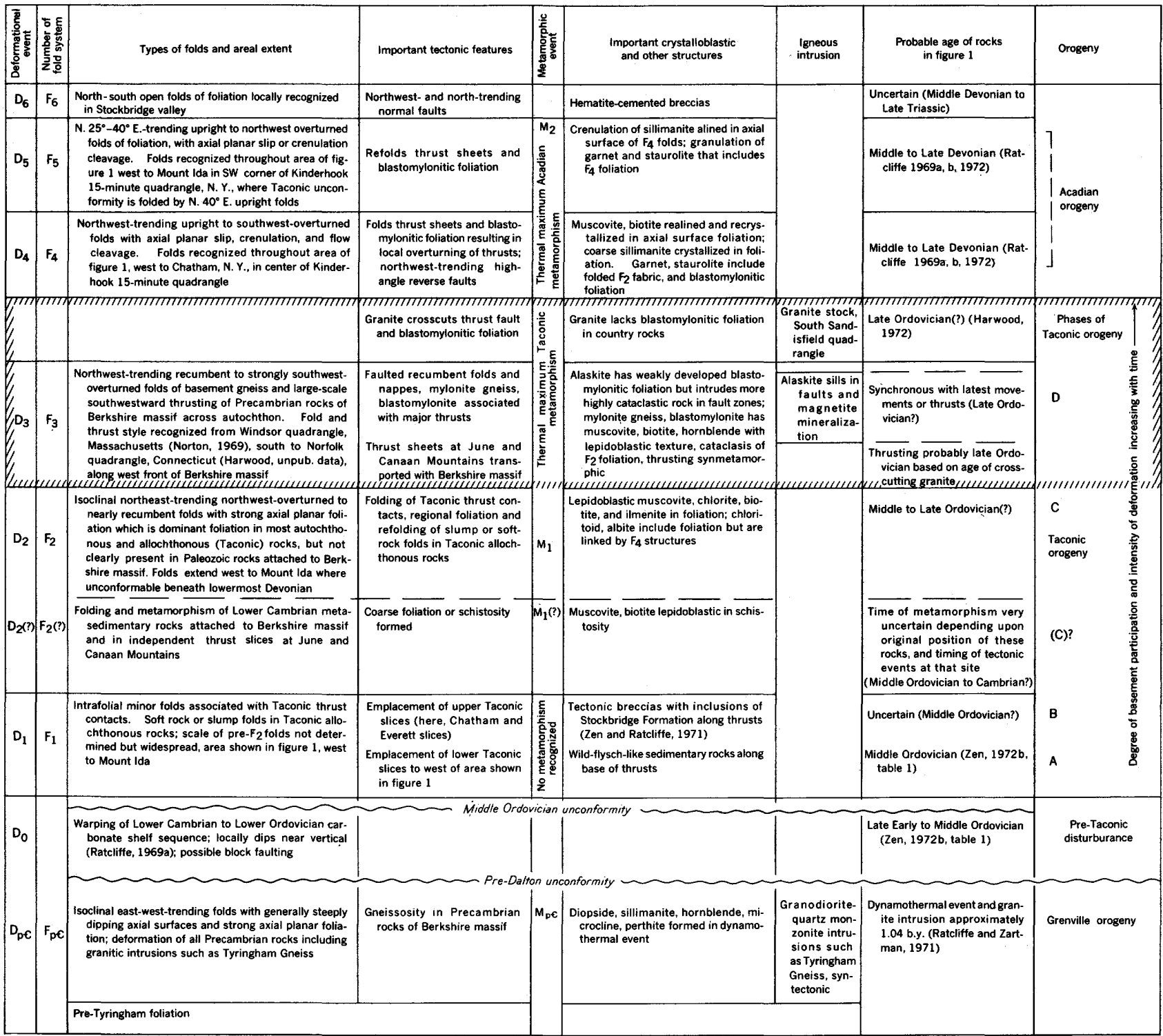

FIGURE 2.-Major tectonic features and deformational events in the Berkshire massif in southwestern Massachusetts and northwestern Connecticut and adjacent New York. Hachured area indicates structures and textures illustrated in this report.

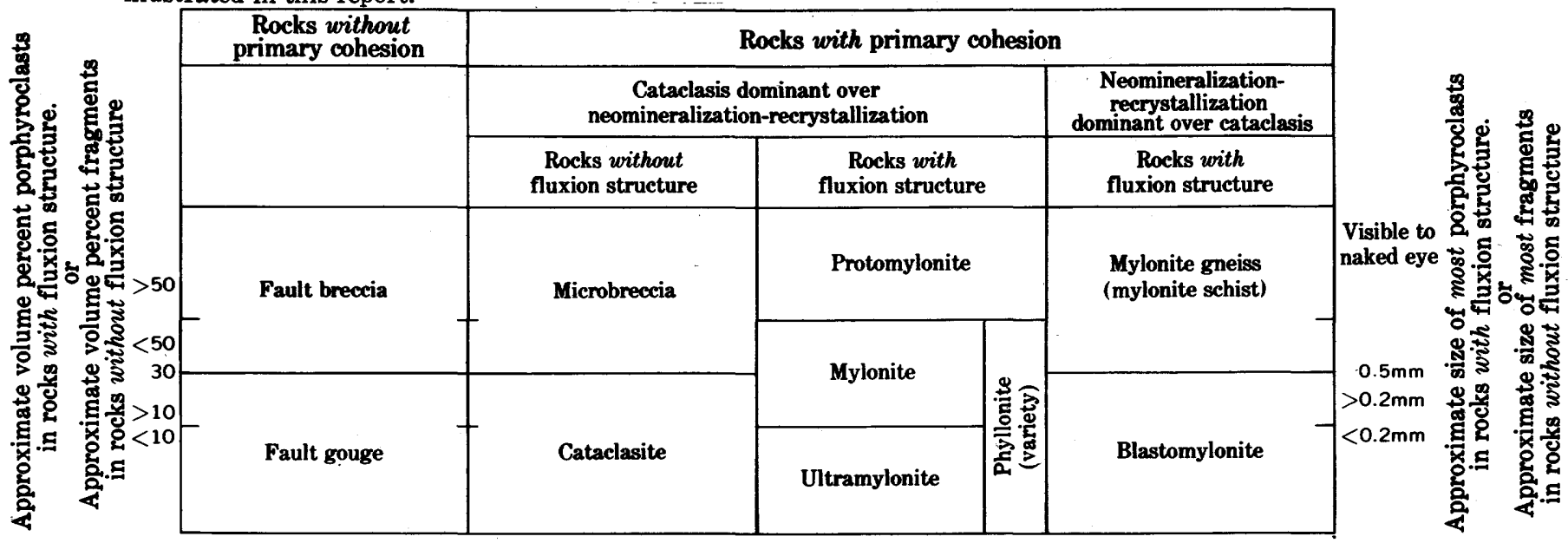

\section{All rocks are gradational}

FIGURE 3.-Classification of cataclastic rocks. Porphyroclastic, protoclastic, diapthoritic, pseudotachylitic, polymetamorphic, polycataclastic, phyllitic, and other terms are used as modifiers (see text). From Higgins $(1971$, table 1). 
in the mylonite gneiss and exhibit numerous minor sheared-off isoclinal folds and trails of minute porphyroclasts of gneiss. These biotite-rich zones are coarsely schistose and are believed to be blastomylonite marking zones of dislocation and intense cataclasis.

Mineral recrystallization along both the thin and thick zones of cataclasis has given rise to a new welldeveloped planar structure here referred to as a blastomylonitic foliation. Because recrystallization rather than cataclasis is the dominant feature in the fabric, the proper term is blastomylonite rather than mylonitic foliation (fig. 3). It is important to note that the blastomylonitic foliation is coincident with and parallel to zones in which cataclastic deformation has been intense enough to destroy coarse Precambrian gneissosity that is preserved as a relict structure outside the immediate vicinity of the faults.

All gradations from incipient fracturing and minor shearing to intensely crushed and recrystallized rock (blastomylonite) may be observed by examination of outcrops, hand specimens, and thin sections of rocks near the thrust faults. In this sense, the fabric we are describing is penetrative.

Shearing and recrystallization are most intense near the faults (fig. 1) and die out away from the faults both in the autochthonous rocks and the thrust sheets. Within $25 \mathrm{~m}$ of faults, the blastomylonitic foliation commonly is a pervasive feature in outcrop, and it may entirely obscure the older gneissic layering, owing to nearly complete crushing and recrystallization.

In addition to intense shearing, the zones near faults also exhibit spectacular recumbent folds that range from millimetres to tens of metres in amplitude and may have wavelength to amplitude ratios of as much as 1:20. Commonly these small-scale folds are sheared off along their inverted limbs, and zones of blastomylonite mark the discontinuity. It is important that the blastomylonitic foliation noted above is axial planar to these folds. Away from the faults, larger recumbent folds are common; they have an axial planar foliation that is approximately coplanar with the thrust surfaces and the zones of blastomylonite. We believe that the major recumbent folds, the blastomylonitic foliation, and the thrust faults formed during a single period of recumbent folding and imbricate thrusting.

\section{BLASTOMYLONITIC TEXTURES IN PALEOZOIC ROCKS}

Upper(?) Ordovician to Upper Precambrian(?) metasedimentary rocks of the Dalton Formation,
Cheshire Quartzite, and the Stockbridge and Walloomsac Formations form the relatively autochthonous sequence onto which the Precambrian crystalline gneisses and metasedimentary cover rocks have been thrust. Metamorphic fold structures and strongly foliated rocks in the autochthon have been truncated by the overthrusts (Ratcliffe, 1969a; $1975 \mathrm{a}$ and $\mathrm{b})$. The fold structures beneath the thrusts are traceable over wide areas to the west of the area shown in figure 1 , in the adjacent State Line quadrangle (Ratcliffe, 1969b, and 1975b) and in the Egremont quadrangle (Zen and Ratcliffe, 1971). Axial plane foliation of these folds trends north-northeast and dips moderately steeply to the southeast. Microtextural studies (Ratcliffe, 1969b) indicate the foliation formed during dynamothermal metamorphism of chlorite to biotite grade, the intensity of which increased to the east. The dominant schistosity and metamorphic fold structures in the autochthonous rocks formed in this event.

Within approximately $100 \mathrm{~m}$ of overthrusts, autochthonous Paleozoic schists and marbles have a unique megascopic and microscopic fabric resulting from overprinting of the older schistosity by the blastomylonitic fabric associated with the thrust sheets. In addition, the Paleozoic metasedimentary rocks of the overthrust sheets also contain a distinctive overprint pattern. In these rocks a preexisting foliation is folded and granulated along blastomylonitic zones subparallel to the fault surfaces.

It is important to note that the blastomylonite zones and blastomylonitic foliation are spatially restricted to fault zones and overprint metamorphic structures in Paleozoic rocks both above and below the thrusts. Therefore, the low-angle thrust faulting postdated at least one episode of early Paleozoic dynamothermal metamorphism (Ratcliffe, 1969a).

Figures 4 through 10 illustrate characteristic te:xtures in these rocks. In all of these rocks, represe:iting staurolite- to sillimanite-grade metamorphism, a strong microcataclastic, blastomylonitic foliation is developed. The blastomylonitic foliation is axial planar to folds that deformed a preexisting foiation. New mineral grains, largely muscovite, biotite, plagioclase, quartz, tourmaline, and locally garnet, have grown during the formation of the blastomylonitic foliation. In general the cataclasis has resulted in a decrease in grain size by granulation of more brittle minerals such as plagioclase and microcline, and by shredding and bending of coarse muscovite. Neomineralized fine-grained biotite is alined in the blastomylonitic foliation. Characteristically this blastomylonitic foliation is spaced irregularly 1 to $5 \mathrm{~mm}$ apart, having sheared-off noses 
of tightly appressed folds of a preexisting foliation preserved between the shear surfaces. Hinge lines of these minor intrafolial folds commonly plunge at low angles down the dip of the blastomylonitic foliation, giving rise to reclined folds. Figure $4 A$ shows the megascopic texture developed approximately 15 $\mathrm{m}$ (50 ft) above the thrust at the Pinnacle at Lee,
Mass. Upon careful examination of the photograph, noses of the folded foliation are visible in the area $4 \mathrm{~cm}$ above and to the left of the coin.

Figure $4 B$ shows the microscopic appearance of the blastomylonite seams shown in $4 A$. Within the sheared zones, the originally interlocking polygonal texture of quartz and feldspar is reduced to a strong

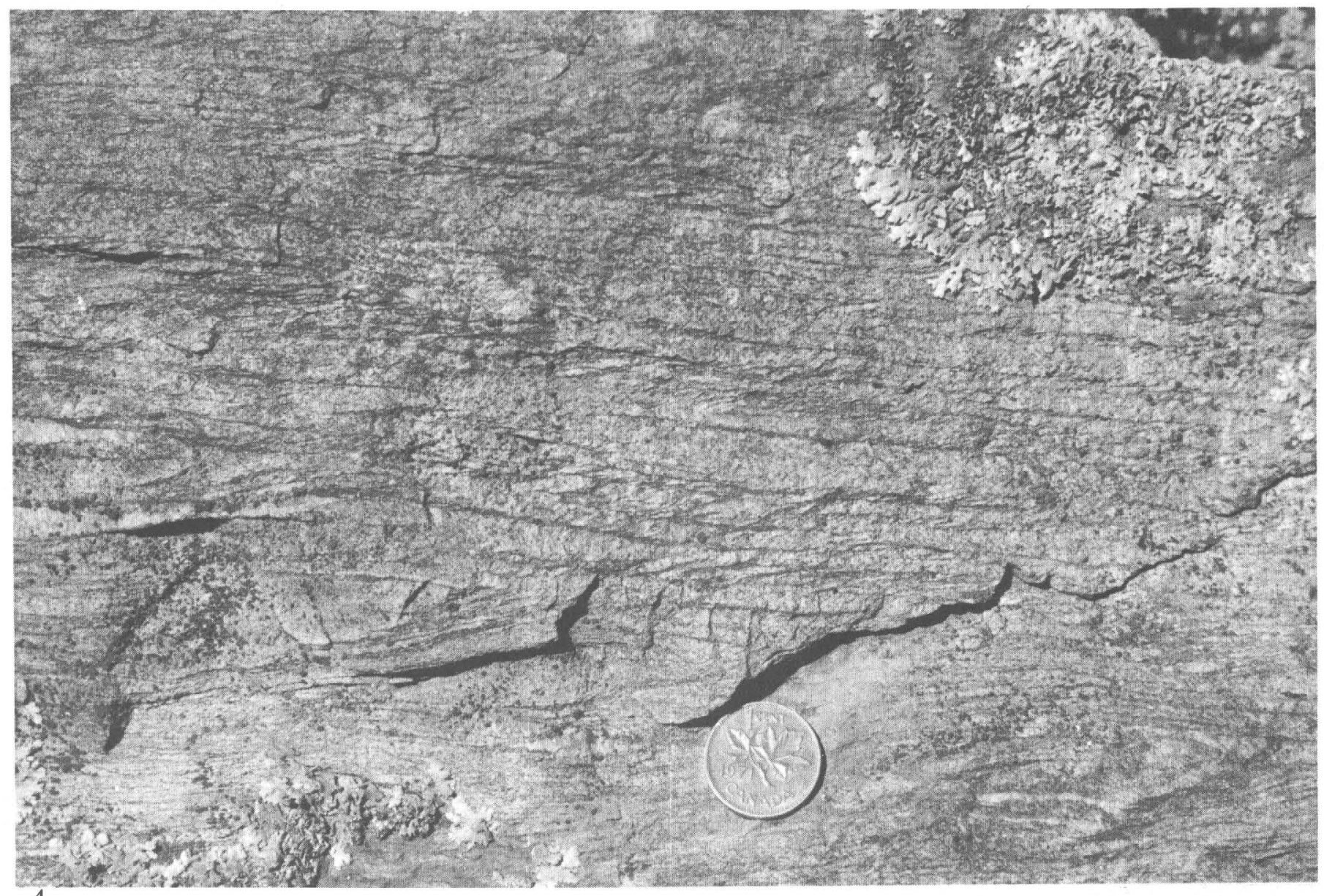

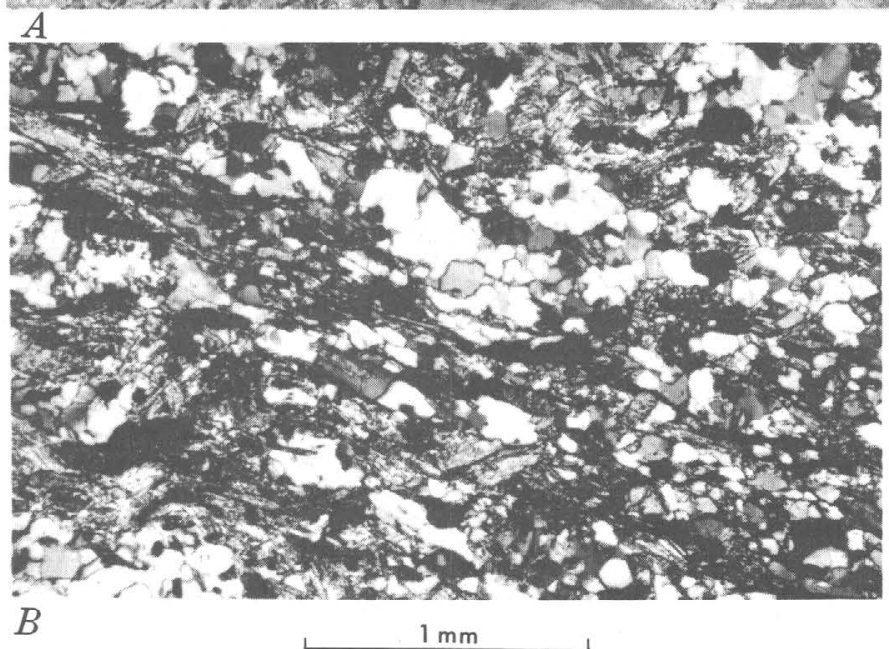

FIGURE 4.-Dalton Formation approximately $15 \mathrm{~m}$ (50 ft) above the thrust placing Dalton over the Stockbridge Formation on the western side of the Pinnacle at Lee, Mass. (fig. 1). A, Blastomylonitic foliation appears as through-going black layers. The view is easterly. The thrust and blastomylonite dip into the outcrop. Minor folds of an earlier foliation are preserved as sheared-off noses of folds contained between fine zones of cataclasis that pervade the rock and produce the dominant structure in outcrop. The relict structure is subtle and can only be observed after careful examination. $B$, Photomicrograph showing zones of sheared lenticular quartz and shredded muscovite that dip east (right in photograph) and correspond to the dark through-going zones of blastomylonite seen in $A$. Between the zones of cataclasis the relict polygonal texture of the rock may be seen. Plane-polarized light. 
planar fabric in which small lenticular quartz grains, muscovite, and biotite are alined. The grain size of the quartz and microcline outside the shear zones ranges from 0.5 to $0.7 \mathrm{~mm}$ but is less than $0.1 \mathrm{~mm}$ within the zones. These textures coupled with the crosscutting relationships of the blastomylonite shown in $4 A$ clearly establish the cataclastic nature of the black seams.

Recrystallized biotite and muscovite are alined in the zones of cataclasis and largely obscure the porphyroclasts, thus indicating recrystallization was significant in producing the resultant fabric. Hence, the seams are regarded as blastomylonite.

Figures $5 A$ and $5 B$ show structures common in the Dalton Formation along the leading edge of the Beartown Mountain nappe at East Mountain. The dominant structures seen in outcrop are east-dipping shear zones spaced 1 to $5 \mathrm{~mm}$ apart. Between the sheared zones minor folds of a preexisting schistosity and relict textures are found. The blastomylonitic seams dip $25^{\circ}$ E., parallel to the contact with underlying Stockbridge marble. A similar structure crosscuts foliation and bedding in the underlying marble.

The Dalton Formation beneath the trailing edge of a slice of Precambrian rock at Warner Mountain contains similar structures. Here, a fine-grained

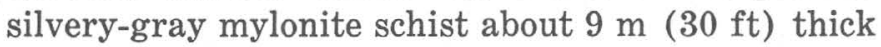
is exposed in the south side of the roadcut on Route $23,46 \mathrm{~m}(150 \mathrm{ft})$ west of the Lake Buel Road intersection. Figures 6 and 7 illustrate structures in the Dalton found immediately beneath the thrust at the base of the Precambrian rocks on Warner Mountain. The photomicrograph (fig. 7) shows the intense west-dipping cataclastic fabric and illustrates the reduction in grain size in zones of cataclasis. New minerals alined in the blastomylonitic foliation include muscovite, brown biotite, quartz, and pyrite.

A photomicrograph of a sample of Wallomsac schist taken $30 \mathrm{~m}$ (100 ft) beneath the trailing edge of the Beartown Mountain slice in the southwestern corner of the East Lee quadrangle is shown in figure 8. In outcrops at this locality foliation dips $25^{\circ} \mathrm{SW}$., beneath the Precambrian gneisses. Although only one foliation is obvious in outcrop, the texture in thin section is a characteristic button schist of the kind reported in the Brevard and other fault zones and illustrated by Higgins (1971, fig. 11). The long axis of the coarse muscovite shown in figure 8 defines a preexisting foliation dipping gently southwest which is intersected by the more steeply dipping cataclastic foliation that weaves around the large muscovite grains resulting in the button tex-

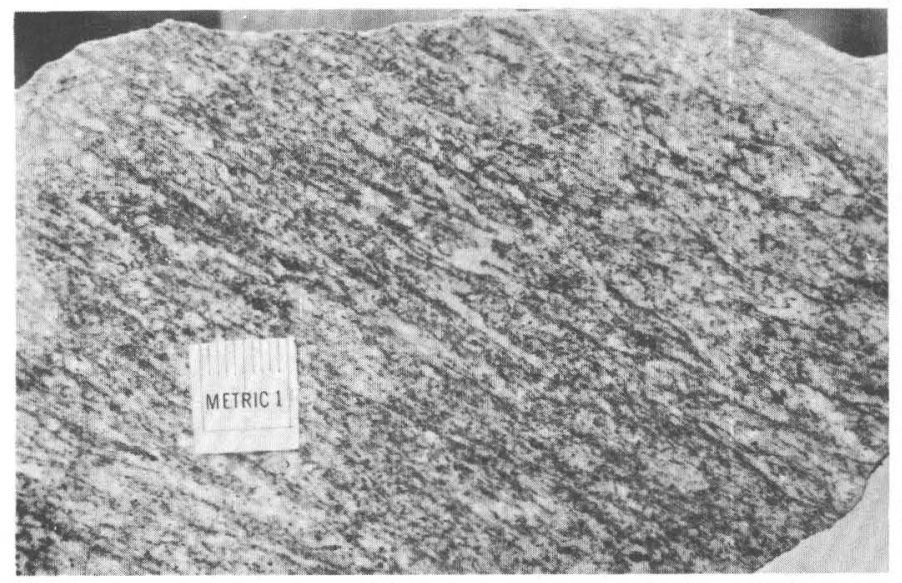

$A$

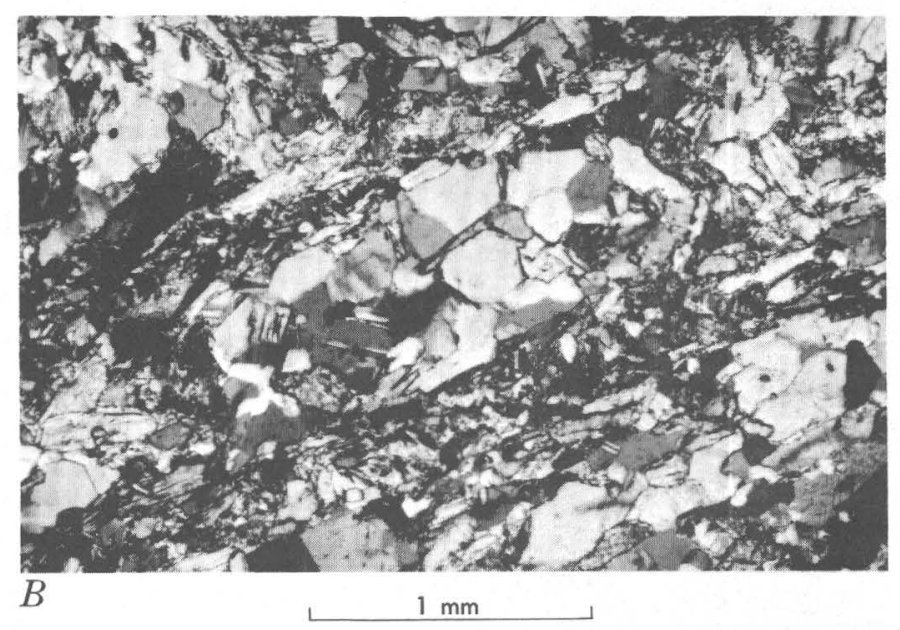

Figure 5.-Dalton Formation from the west side of East Mountain, $10 \mathrm{~m}$ above the thrust that places Dalton on the Stockbridge marble alon $;$ the leading edge of the Beartown nappe (fig. 1). A, Polished hand specimen of highly folded and sheared Dalton Formation. Abundant minor folds of a preexisting schistosity have sheared-off limbs marked by dark through-going sean:s of blastomylonite. Blastomylonitic foliation dips east toward right in photograph, parallel to the contact with the Stockbridge. $B$, Photmicrograph illustrates the cataclastic texture of the shear zones shown in $A$. A porphyroclast comrosed of an aggregate of polygonal quartz is surrounded by intensely sheared and comminuted quartz and oriented biotite. The original texture of the rock is illustrated in the porj)hyroclast. Shear zones dip east (to left in photograph). Crossed polarizers.

ture. Fine-grained lepidoblastic biotite, muscovite, and green tourmaline and small granules of quartz are concentrated in the cataclastic foliation. Figure 9 shows the shredding along one border of a large muscovite button and the development of new lepidoblastic biotite in the blastomylonitic foliation.

Excellent exposures of severely deformed Dalton beneath the sole of the Beartown Mountain slice can 


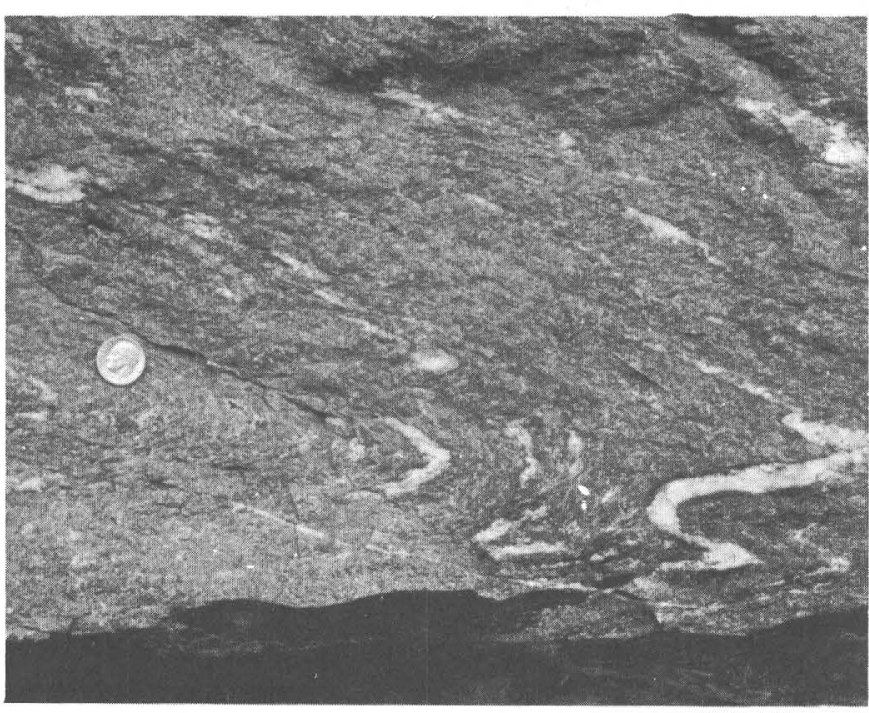

FigURE 6.-Fine-grained mylonite schist of the Dalton Formation approximately $7 \mathrm{~m}$ (20 ft) beneath thrust of Precambrian rock at Warner Mountain roadcut on Route 23 near Lake Buel Road. The blastomylonitic foliation is axial planar to the folds in a preexisting foliation and dips $10^{\circ} \mathrm{W}$. (to the right in photograph).

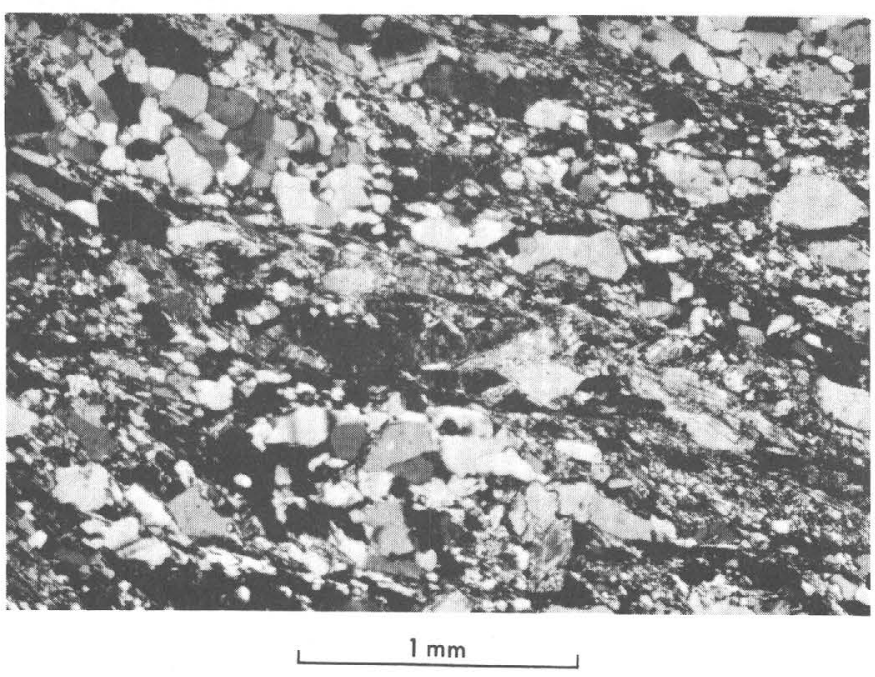

FigURE 7.-Photomicrograph of mylonite schist shown in figure 6. Approximately 7 zones of very fine-grained blastomylonite $0.5 \mathrm{~mm}$ thick dip from left to right (east to west). Areas of relatively coarser grained polygonal quartz and grid-twinned microcline $0.5 \mathrm{~mm}$ in diameter are relict structures preserved between the zones of granulation. One almond-shaped porphyroclast of schist bounded by thin sheared zones marked by lenticular quartz, microcline, and shredded muscovite is shown in the left-center of the photograph. The blastomylonitic structure observed here is axial planar to folds of the schistosity shown in figure 6 , and is nearly perpendicular to the original compositional layering seen in figure 6. Quartz grains approximately 0.5 to $1 \mathrm{~mm}$ in diameter are reduced to minute white specks $0.1 \mathrm{~mm}$ in size in zones of granulation. Because the blastomylonitic foliation is closely spaced, about $1 \mathrm{~mm}$ apart, it is not easily discernible on figure 6 . Crossed polarizers.

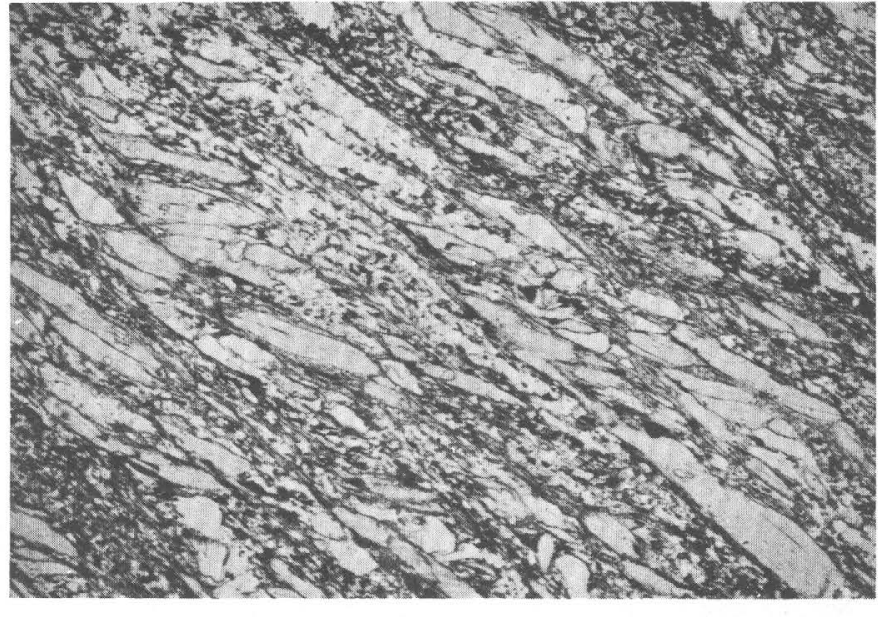

$1 \mathrm{~mm}$

Figure 8.-Photomicrograph of mylonite schist of the Walloomsac, $30 \mathrm{~m}$ beneath trailing edge of Beartown Mountain slice in the East Lee quadrangle. The blastomylonite foliation dips $25^{\circ} \mathrm{SW}$. (to the right in photograph) beneath the Precambrian gneiss and produces a characteristic button schist structure. Plane-polarized light.

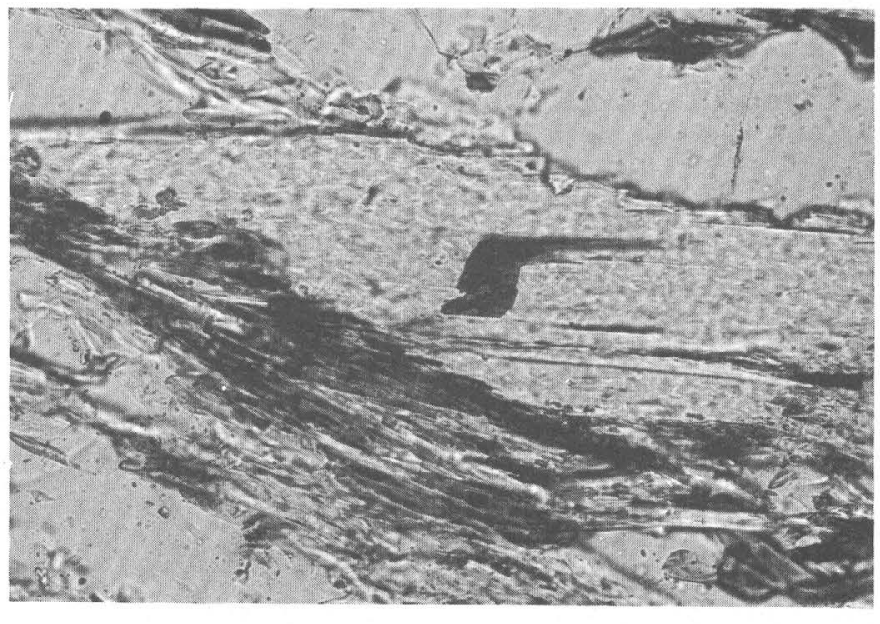

$1 \mathrm{~mm}$

FIGURE 9.-Photomicrograph showing close up view of single muscovite button located approximately in the center of figure 8 having shredding at lower edge of the porphyroclast and the small lepidoblastic biotite defining the blasomylonite foliation. Note noncataclastic texture at top of muscovite. The trace of the (001) cleavage in the large muscovite button probably defines the orientation of the older foliation. The blastomylonitic foliation dips more steeply to the southwest (to the right in photograph). Plane-polarized light.

be seen north of Monterey. Samples of the Dalton (fig. 10) have a button texture similar to that described from the Walloomsac. Figure 10 shows a single bent and sheared crystal of muscovite having penetrative blastomylonitic foliation in which finer grained biotite and muscovite are crystallized. Discontinuous trails of magnetite are concentrated 
along the zones of cataclasis. The blastomylonite foliation dips $10^{\circ} \mathrm{N}$. beneath the overriding Precambrian rocks. The sample is approximately $30 \mathrm{~m}$ $(100 \mathrm{ft})$ below the base of the overriding gneiss.

Figures 11 and 12 are samples of Walloomsac from the leading edge of the Lake Buel slice (fig. 1) in the southeastern corner of the Great Barrington quadrangle. Foliation in outcrop dips northwest. In figure 11 a small isocline of folded foliation is preserved between two zones of cataclasis in which lepidoblastic biotite and muscovite are found. The older foliation consists of biotite, muscovite, and plagioclase bent to produce the fold nose. Garnet (fig. 12) within the same rock has inclusion textures suggestive of syntectonic growth within the blastomylonitic foliation. Because garnet includes the blastomylonitic fabric, either it was growing in this rock during the episode that produced the blastomylonite or it formed afterward. The inclusion-free rims suggest garnet overgrowths that could have formed by late, static crystallization.

Rotated garnets are not common within the area shown on figure 1 and appear to be restricted to localities where the blastomylonitic foliation is present.

Petrographic examination of the folded foliations in Paleozoic rocks near fault zones indicates that the prethrust metamorphism was sufficiently high grade to produce muscovite and biotite in the Dalton

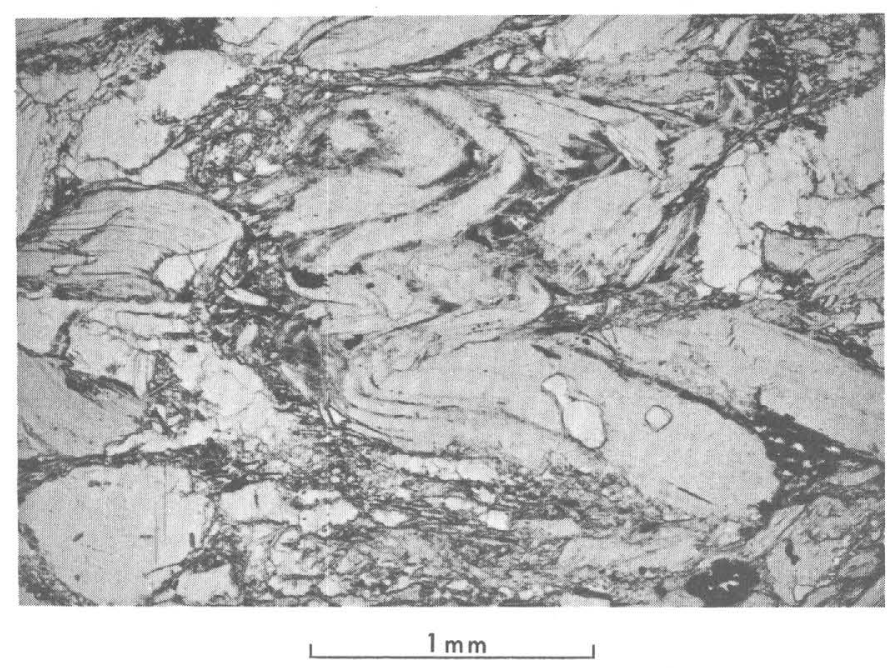

FIGURE 10.-Photomicrograph of bent and sheared muscovite in Dalton Formation approximately $30 \mathrm{~m}$ (100 ft) beneath the overriding Precambrian gneisses at Monterey, Mass. The blastomylonitic foliation is axial planar to recumbent folds in thin section and outcrop in both the gneiss and the Dalton. Note the comminuted material in the shear zone at the top of the photograph. Plane-polarized light.

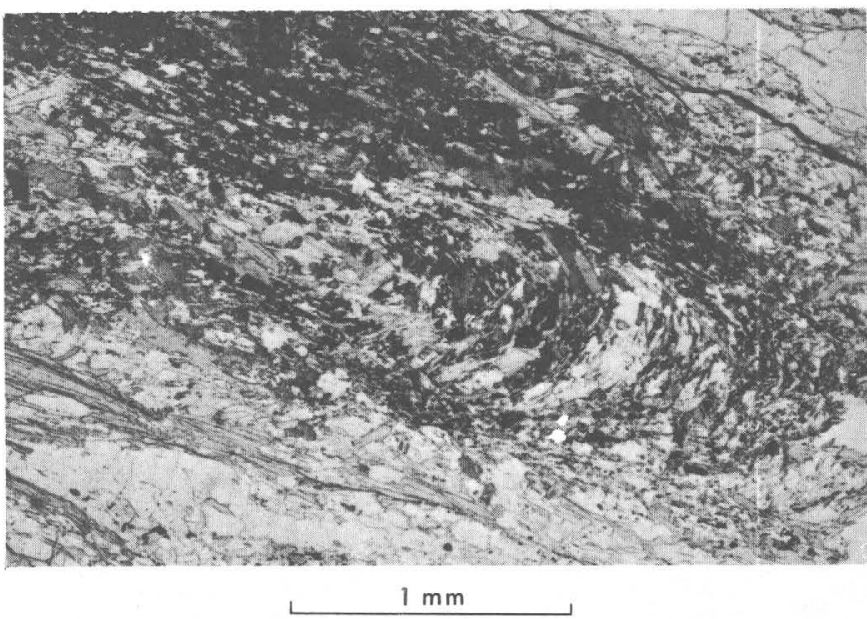

Figure 11.-Photomicrograph of Walloomsac at leading edge of Lake Buel slice. Blastomylonitic foliation marks shearedoff limbs of isocline in earlier foliation. Note folded mica in hinge of fold and new biotite that defines blastomylonitic foliation, which dips northwest (to the right in photograph). Plane-polarized light.

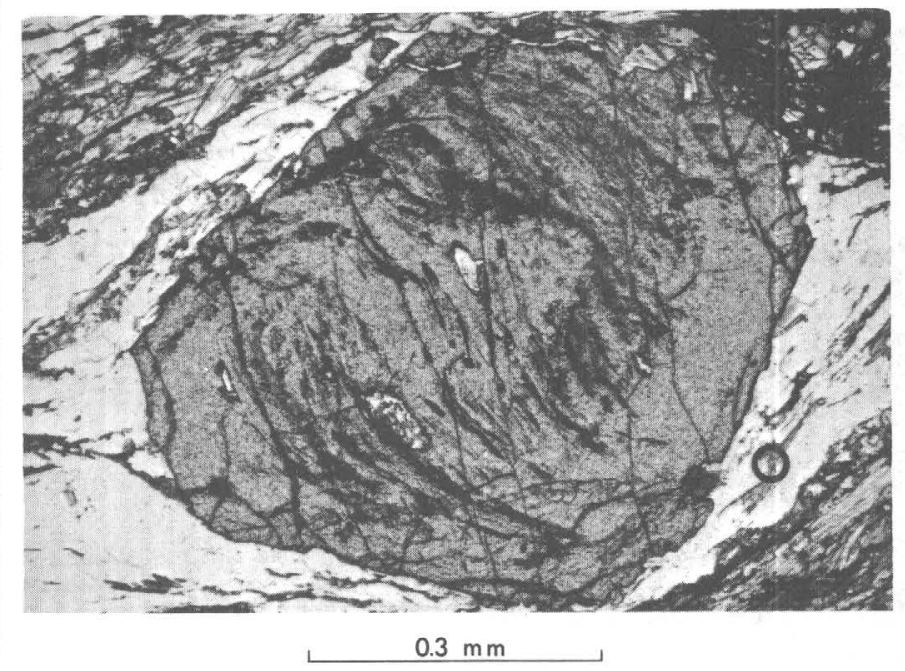

FIGURE 12.-Photomicrograph of garnet rotated in blastomylonitic foliation shown in figure 11. Texture implies garnet grew during movement on blastomylonitic foliation. Planepolarized light

and muscovite, biotite, and plagioclase in the Walloomsac.

In all cases the small-scale shearing pervading the rock has reduced the grain size of previously schistose rocks by crushing or shredding, and the newly formed lepidoblastic minerals are smaller grained than the original minerals. Evidently thrusting took place under metamorphic conditions sufficiently high to produce biotite and muscovite in pelitic rocks. 


\section{BLASTOMYLONITIC TEXTURES IN PRECAMBRIAN ROCKS}

Precambrian gneisses in the Berkshire massif exhibit well-developed gneissic layering and mineral lineations in which hornblende, biotite, and less commonly muscovite are alined. Deformation in Precambrian time was accompanied by syntectonic intrusion of granitic rocks such as the Tyringham Gneiss, from which the zircon yields a U-Pb concordia age of about 1.04 b.y. (Ratcliffe and Zartman, 1971). The gneissosity in the Precambrian rocks is truncated by the unconformity beneath the Lower Cambrian and Upper Precambrian(?) Dalton Formation, thus confirming that the gneissic fabric is Precambrian (Ratcliffe, 1969a).

Paleozoic deformation has modified the Precambrian gneissosity to varying degrees, the most intense and thorough textural changes appear at or near the thrust faults shown in figure 1. At some of the thrust faults there is dark-gray, coarsely crystalline, biotite-rich blastomylonite and mylonite gneiss in which nearly all traces of Precambrian mineralogy and textures are destroyed. Some of these zones are as much as $7 \mathrm{~m} \mathrm{(20} \mathrm{ft)} \mathrm{thick,} \mathrm{but}$ this is not common or, at least, not well exposed. More commonly, within a few metres (tens of feet) to tens of metres (a few hundred feet) above and below the faults a distinctive blastomylonitic foliation is developed that is associated with zones of intense recumbent folding. Commonly in highly folded zones minor folds have sheared-off limbs that are marked by dark zones of granulated mylonitic gneiss or blastomylonite with a strong schistosity parallel to the discontinuity. The intensity of both folding and shearing increases toward the faults.

At distances greater than $300 \mathrm{~m}(1,000 \mathrm{ft})$ above or below faults the blastomylonitic fabric is difficult to detect in outcrop but may be recognized in thin section as a pervasive new foliation accentuated by growth of new mica. This foliation is axial planar to megascopic and major folds of the Precambrian gneissosity that are recumbent or strongly overturned to the southwest.

\section{APPEARANCE OF BLASTOMYLONITIC FABRIC IN OUTCROP AND THIN SECTION}

Within the area shown in figure 1 the megascopic fabric in Precambrian rocks near the thrust faults suggests deformation modes that range from relatively brittle to relatively ductile. At one extreme, shearing along discrete slip planes (zones of blastomylonite) several centimetres thick appears to have produced the observable strain; cataclastic and porphyroclastic textures are dominant. In other cases, slip on discrete planes is coupled with the development of abundant strain-slip folds in which microscopic zones of blastomylonitic fabric form the axial planes. In the latter cases the amount of slip between adjacent slip planes is relatively small, and the total strain in the rock results from the cumulative effect of strain-slip folding. Porphyroclastic structures are microscopic in these rocks, and the blastomylonitic foliation is truly penetrative. The discrete slip planes in both cases resemble strain discontinuities referred to as ductile faults by Donath and others (1971), and many of the blastomylonites described here appear to have formed as a result of ductile strain rather than brittle fracture in which rock cohesion is lost.

Figures 13 through 16 illustrate some cataclastic structures in gneisses of the blastomylonite zones identified on figure 1 . The photographs are arranged in order of increasing degree of cataclasis and illustrate the different kinds of blastomylonite and mylonite gneiss found. Although the samples are from different localities, structures similar to those pictured can be found in most of the fault zones.

In addition to structures clearly identifiable as cataclastic, gneissic rocks adjacent to the tectonically lower faults exhibit intense recumbent folding of the gneissic layering. Recumbent isoclines have limbs strongly attenuated about axial surfaces parallel to the blastomylonitic foliation. Fold axes plunge from horizontal to directly down the dip of the axial surface yielding reclined folds. The folds are commonly asymmetrical with a strong northeast over southwest movement sense. Inverted limbs of minor recumbent antiforms are commonly sheared out along seams of blastomylonite. Figures 17 through 19 show structures seen in hand specimen that illustrate a combination fold and fault or "fold-thrust" fabric. The discontinuities pictured do not suggest brittle failure and many represent natural examples of ductile faults described by Donath and others (1971) from the study of experimentally deformed rocks.

\section{SPATIAL RELATIONSHIP OF CATACLASTIC STRUCTURES, RECUMBENT FOLDS, AND MAJOR FAULTS}

Within the area of figure 1 the textures and structures described thus far are restricted to zones of rock as much as $300 \mathrm{~m}$ thick bordering the major low-angle faults. However deformation styles in the fault zones differ depending on the position of the thrust relative to the other thrust slices in the Berkshire massif. In general, zones adjacent to the major 
thrusts at the base of the tectonic pile, that is, the Beartown Mountain slice and the imbricate slices in the southern part of the map, exhibit a greater

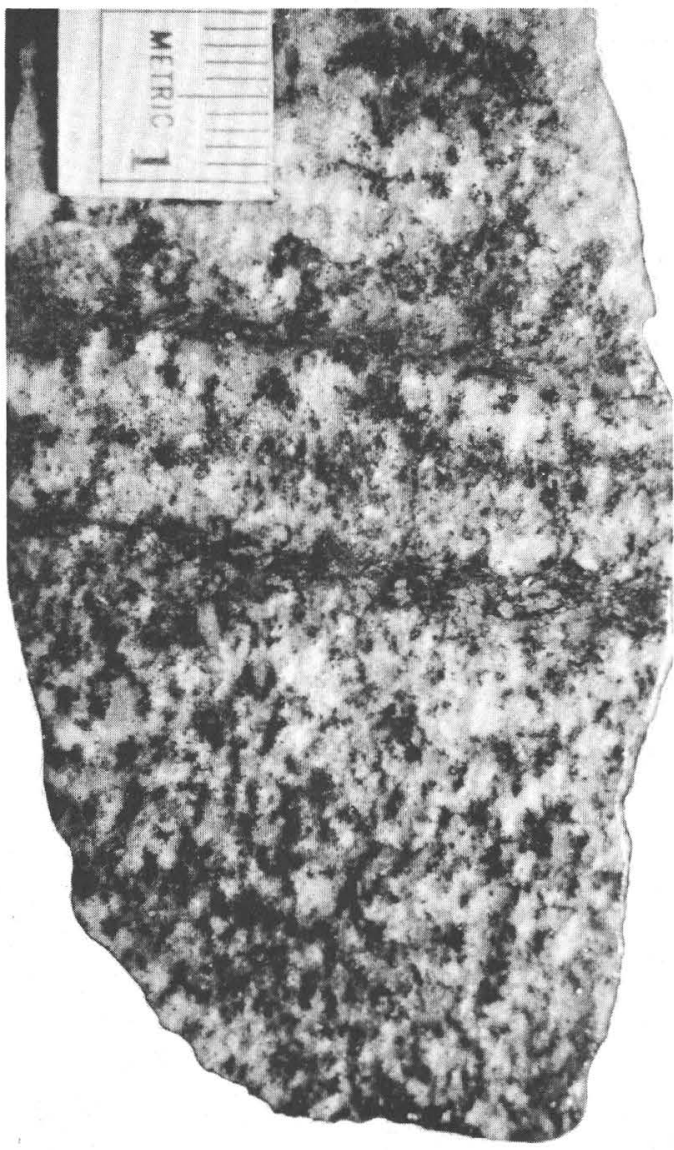

FIGURE 13.-Biotite-ferrohastingsite granite gneiss approximately $100 \mathrm{~m}$ above the Beartown Mountain thrust at Halls Hill, Monterey quadrangle (fig. 1). In outcrop, Precambrian gneissosity is folded into nearly recumbent isoclinal folds with axial surfaces striking N. $10^{\circ} \mathrm{W}$. and dipping $10^{\circ} \mathrm{NE}$. Sample from hinge of recumbent fold where the Precambrian gneissosity strikes N. $70^{\circ}$ E. and is nearly vertical (as in photograph). In photograph two zones of blastomylonite dipping to northeast (right in photograph) transect the nearly vertical relict gneissic structure outlined by coarse clots of biotite and ferrohastingsite. The blastomylonite is spaced about 1 $\mathrm{cm}$ apart in the rock and is coplanar with the axial surface of the folds observed in outcrop. Blastomylonite seams consist of brown biotite, apatite, clinozoisite, granulated quartz, and abundant magnetite. The relict Precambrian gneissosity contains vertically oriented lepidoblastic green biotite, ferrohastingsite, oligoclase, and microcline perthite. Mineral reactions involving the destruction of green biotite, ferrohastingsite, microcline perthite, and oligoclase have given rise to the new mineralogy in the blastomylonite.
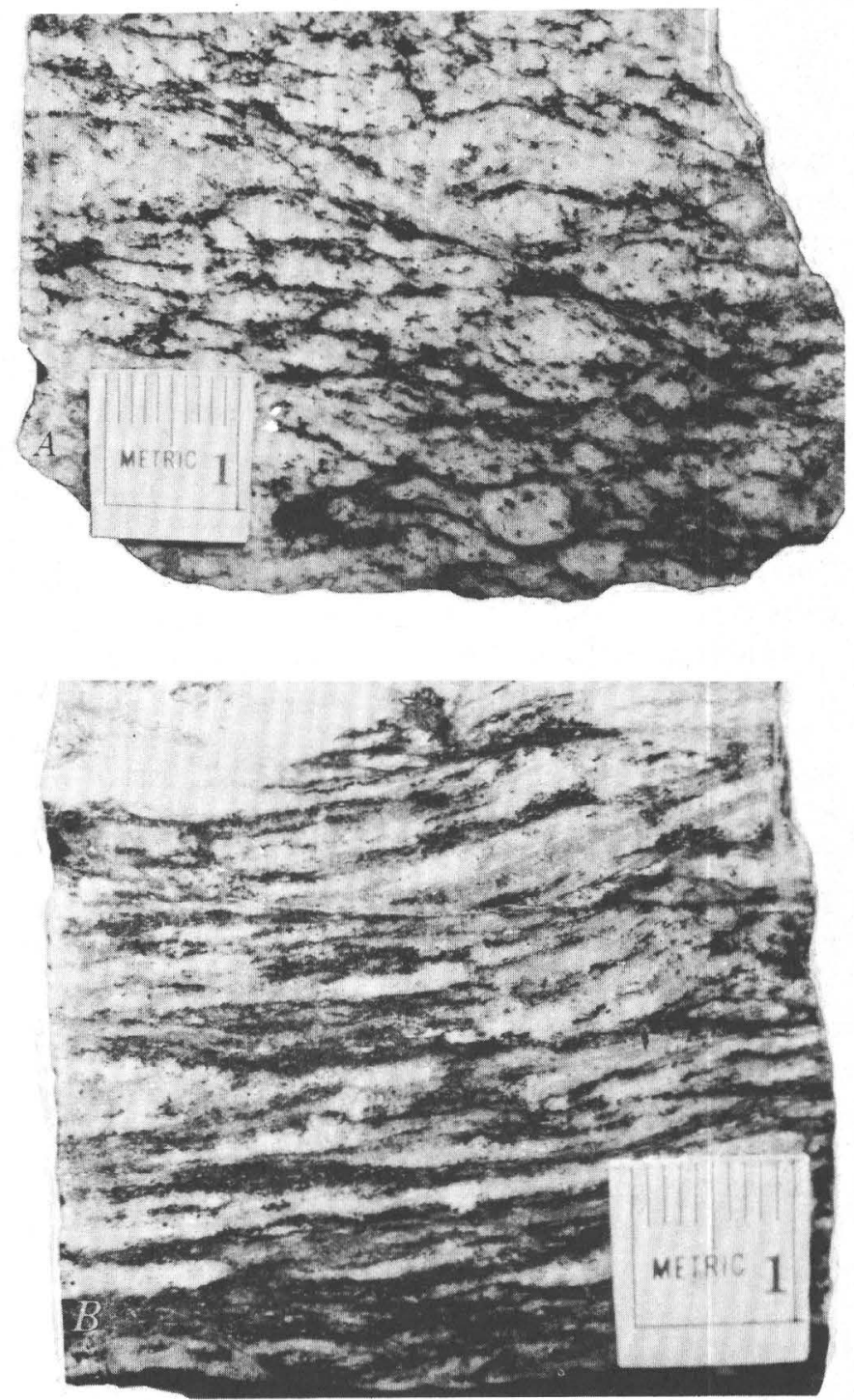

FIGURE 14.-Photographs of cataclastically deformed granite gneiss $10 \mathrm{~m}$ from fault northeast of Lee, Mass. $A$, Sample cut parallel to strike of blastomylonitic foliation. $B$, Same sample cut perpendicular to strike. In $A$, elliptical porphyroclasts of granite gneiss are surrounded by interweaving cataclastic zones accentuated by concentrations of dark lepidoblastic biotite. In $B$, the long axes of porphyroclasts extend down dip of the blastomylonitic foliation. Structures illustrated here may pervade whole outcrops $25 \mathrm{~m}$ in thickness near faults and are more clearly cataclastic than those illustrated in figure 13.

degree of ductile deformation (isoclinal folding) than fault slices exposed in the northeastern part of the map which are tectonically higher. Zones of deformed rocks adjacent to the higher slices exhibit less severe recumbent folding and are marked by greater development of cataclastic and porphyroclastic structures.

The reason for this difference in style is not understood but could result from any one or a com- 


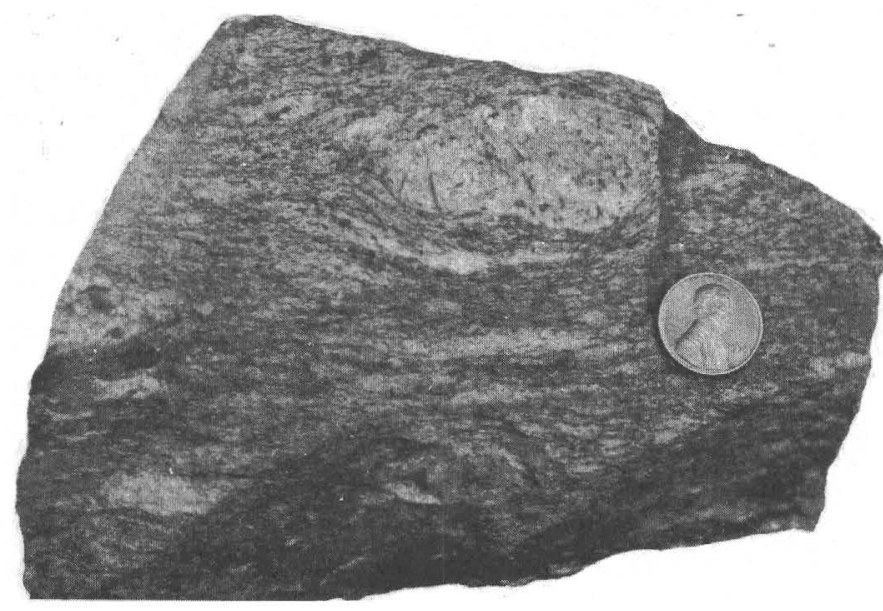

FIGURE 15.-Mylonite gneiss with porphyroclasts of granite gneiss from low-angle fault zone, Pittsfield-Washington Road, at Washington town line, Pittsfield East quadrangle. Fine-grained horizontal blastomylonitic foliation in rock consists of crushed and granulated feldspar with alined biotite. Sampled outcrop locality to north of figure 1 .

bination of the following factors:

1. The major thrusting was concentrated along the contact between the autochthonous rocks and the overriding gneiss, and higher slices were ancillary faults with relatively minor movement and hence subjected only to relatively little stress.

2. Deformation along the sole of the lower thrusts was more ductile owing to increased tectonic overburden of the stacked slices. If the thrust slices did overlap one another northeastward, as proposed, approximately 3 or $4 \mathrm{~km}$ of additional rock could have overlain the lowest slice in the southern part of the map.

3. Thrusting took place during metamorphism that increased progressively to the southeast, hence allowing more ductile behavior.

This last point is an appealing solution because of the observed increase from staurolite to sillimanite grade toward the southeast (fig. 1). However, our studies indicate isograds of this high-grade Barrovian-style metamorphism pass undeflected from autochthonous rocks into the overthrust sheets, thus suggesting the high-grade metamporphism postdated the low-angle faulting. However, we know from the blastomylonites that metamorphic recrystallization did accompany faulting and that this grade was sufficiently high to produce muscovite, biotite, and hornblende in the zones of cataclasis.

The deformation style seen in the deformed zones associated with the lower slices resembles closely the fold style of major folds formed within thrust slices. This is well illustrated by the recumbent folds

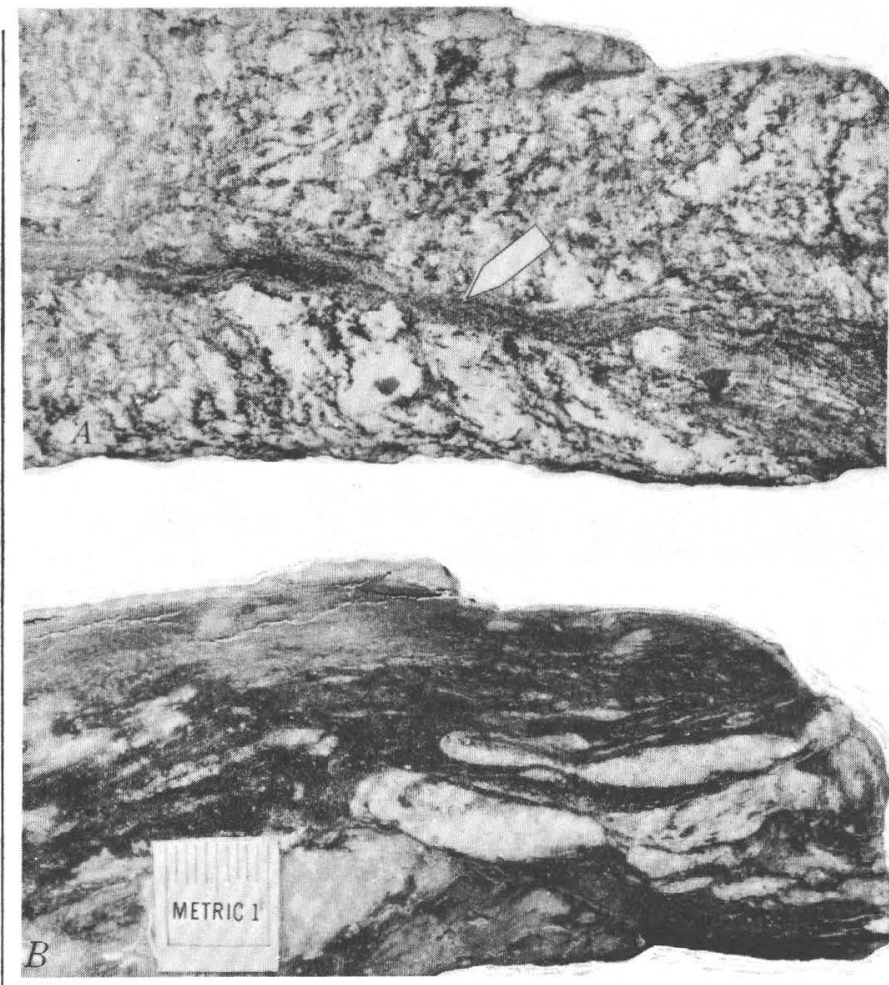

Figure 16.- $A$, Blastomylonite seam $0.5 \mathrm{~cm}$ thick in hand specimen of deformed Precambrian gneiss in fault zone above Goose Pond, East Lee quadrangle. Relict Precambrian gneissosity is vertical, folded, and sheared along subhorizontal surfaces. The dark granulated zone shown by pointer is zone of blastomylonite that transects gneissosity. Specimen comes from outcrop pictured in figure $21 A$, and $B . B$, Finegrained, dark-gray, biotite-rich, 4-cm-thick blastomylonite from sheared zone in mylonite gneiss $15 \mathrm{~m}$ above fault thrusting granitic gneiss over Cheshire Quartzite in the Pittsfield East quadrangle. Minor isoclinal folds of porphyroclastic gneiss are sheared off along their limbs. The darkgray matrix at the top of the specimen contains minute porphyroclasts less than $1 \mathrm{~mm}$ in diameter. In outcrop this shear zone transects gneissic layering for $5 \mathrm{~m}$ along face of exposure.

and thrust faults in the northwest part of the South Sandisfield quadrangle shown in figure 20. Here, thin and distinctive Precambrian units, including a calc-silcate marker unit, outline major recumbent folds in imbricate thrust slices near the base of the major Beartown Mountain slice. The inverted limbs of major recumbent anticlines are sheared out along the thrusts, which transpose segments of the distinctive Precambrian section over each other and, at the base of the lowest slice, over the Dalton, Stockbridge, and Walloomsac Formations (lower Paleozoic or older).

The major folds and faults shown at map scale resemble in attitude and geometry the fold-thrust fabric found in outcrop and hand specimens from near the major faults (figs. 17-19). Recumbent folds 


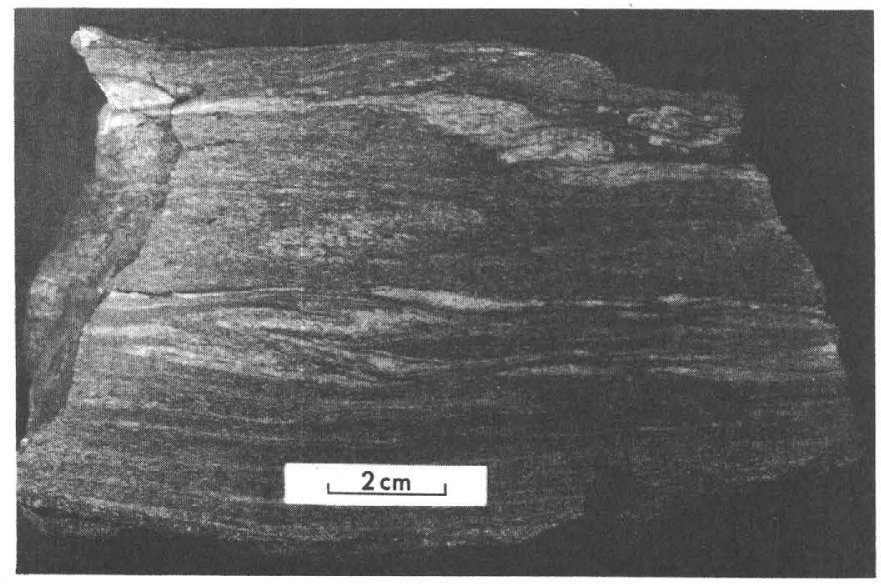

FIGURE 17.-Hand specimen of highly sheared mylonite gneiss approximately $30 \mathrm{~m}$ (100 ft) above base of Beartown Mountain slice that places Precambrian Washington Gneiss on Dalton Formation, Cheshire Quartzite, and Stockbridge and Walloomsac Formations south of Halls Hill in the Monterey quadrangle (fig. 1). Blastomylonitic foliation that dips $20^{\circ}$ SE. (to left in photograph) is axial planar to nearly recumbent folds of gneissic layering that are sheared out along their long limbs. In outcrop this rock is a dark-gray biotite schist with porphyroclasts of gneiss preserved on the noses and short limbs of isoclinal right-handed minor folds. Intense shearing pervades the rock, and cataclasis is concerntrated in zones spaced approximately $5 \mathrm{~cm}$ apart resulting in discontinuous wispy streaks of gneissic layering. The new fabric has nearly completely destroyed the older gneissosity.

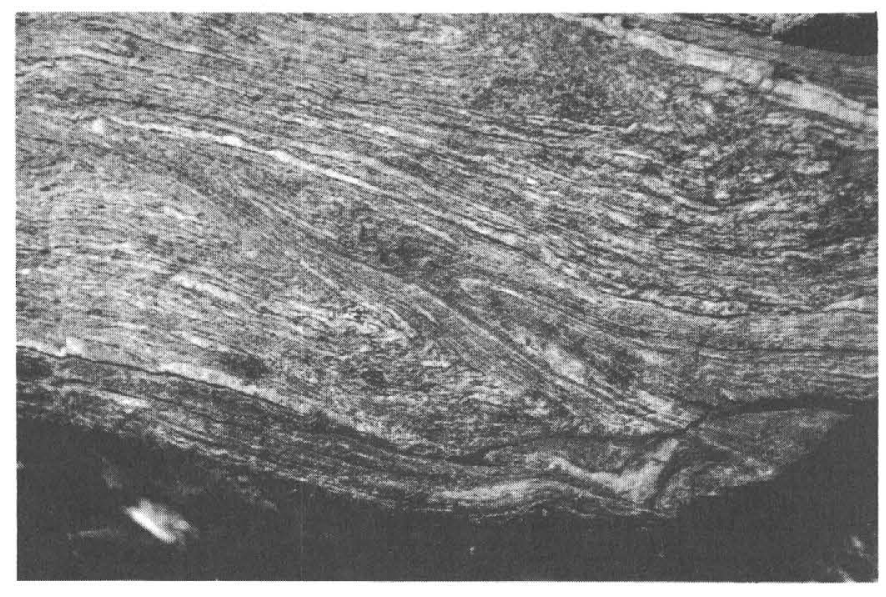

$10 \mathrm{~cm}$

Figure 18.-Recumbent antiform outlined by Precambrian gneissosity in biotite-ferrohastingsite granite gneiss on west slopes of Benton Hill approximately $10 \mathrm{~m}$ above thrust contact that places Precambrian gneiss on the Walloomsac Formation (Upper(?) and Middle Ordovician). Inverted antiform is sheared out along lower limb where blastomylonitic foliation is intense. Note reduction of grain size and destruction of original gneissic fabric. Another strongly sheared zone is shown in the top right corner of photograph accentuated by a secondary quartz vein parallel to discontinuity in the gneissic fabric. Axial planes of minor folds and blastomylonitic foliation strikes north and dips $10^{\circ} \mathrm{E}$. (picture is not horizontal).

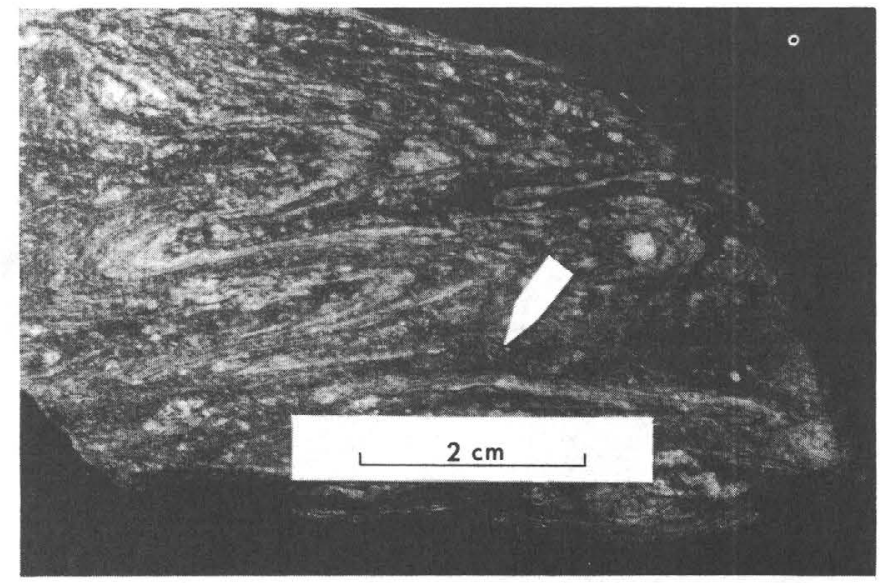

FIGURE 19.-Hand specimen showing tightly appressed isoclines in Precambrian foliation between dark layers of blastomylonitic fabric. Light layers in isoclines are rich in quartz and plagioclase; dark layers are rich in hornblende and biotite. A prominent through-going blastomylonitic layer composed of fine-grained biotite with finely comminuted quartz, plagioclase, and minor hornblende is identified by pointer. Blastomylonitic fabric strikes north, dips east (to left) at $10^{\circ}$.

similar to those shown in figure 20 are abundantly developed throughout the area shown in figure 1 in rocks of the Beartown Mountain slice. The Beartown Mountain slice is a large isoclinal recumbent fold, the brow region of which is exposed in the arcuate belt of outliers at Rattlesnake Mountain, Monument Mountain, East Mountain, Alum Hill, and Rattlesnake Hill (Ratcliffe, 1969a; 1975a and b). The structures shown in figure 20 extend north to Monterey and probably represent lower limb digitations on a larger recumbent fold.

Axial surfaces of isoclinal, strongly overturned to nearly recumbent folds with axial planar blastomylonitic foliation are shown on figure 1 . We believe these folds formed in response to the same tectonic forces that drove the thrust slices at least $21 \mathrm{~km}$ across the underlying autochthonous rocks. The remarkable similarity between the fold-thrust fabric as seen in hand specimen and as portrayed at quadrangle-map scale suggests to us recumbent folding, cataclasis, and low-angle thrusting were all part of a single tectonic episode. However, we cannot say with certainty whether recumbent folding preceded faulting or whether the recumbent folds formed in response to stresses within and between independently moving wedges of basement rock.

To illustrate structures commonly associated with the higher slices, examples will be described from a thrust fault south of the Massachusetts Turnpike (fig. 1) that places Tyringham Gneiss (Emerson, 1898) in thrust contact with itself. Shearing con- 

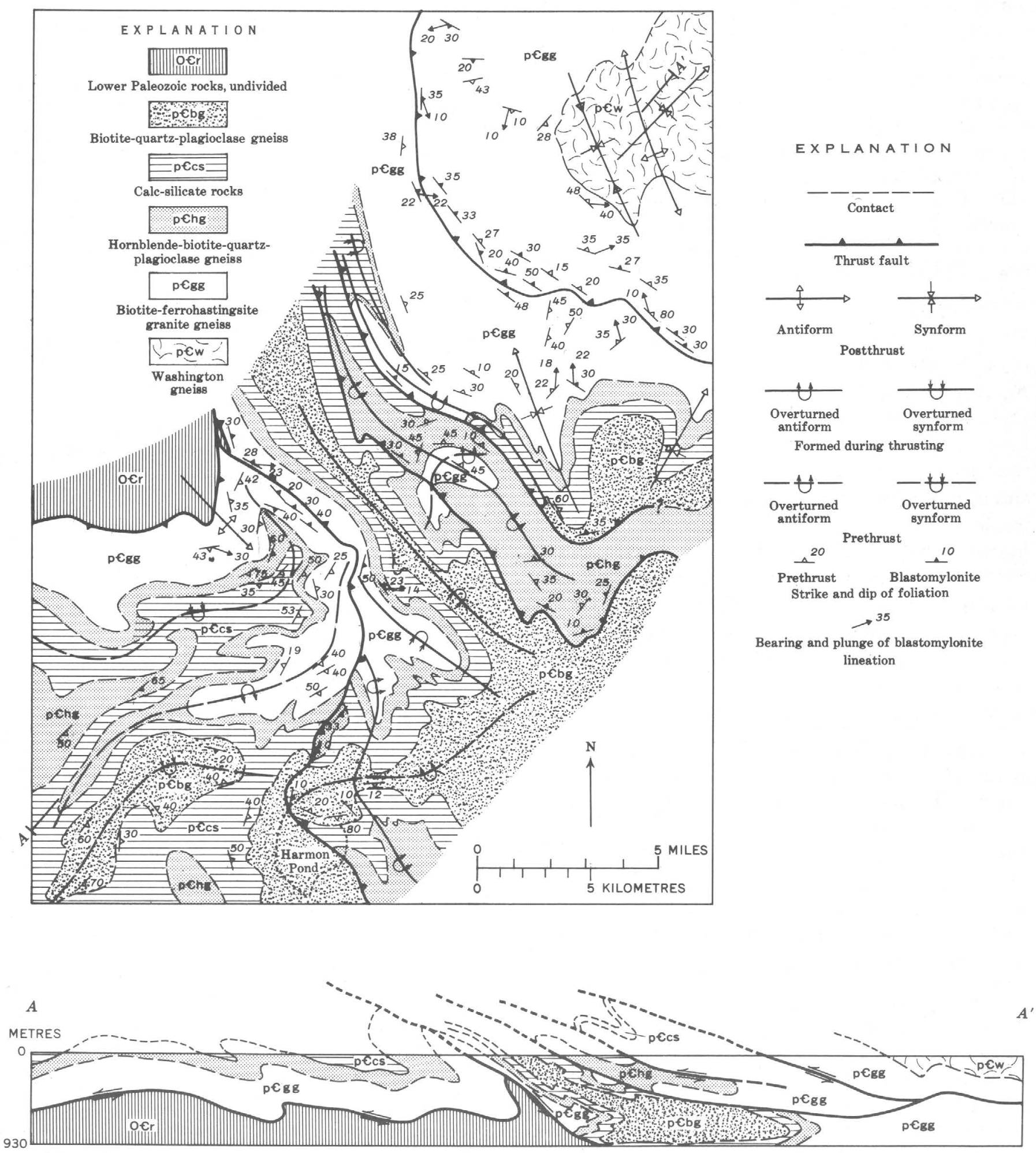

FIGURE 20.-Detailed geologic map and cross section showing major recumbent folds and fold-thrust relationships in the northwestern part of the South Sandisfield quadrangle. See figure 1 for regional setting.

centrated along the sole of the thrust produced a mappable unit of blastomylonite and mylonite gneiss 10 to $15 \mathrm{~m}$ thick. Progressive development of cata- clastic textures in grantic gneiss of the Tyringham is illustrated in figures $21 A, B$ and $22 A, B$. In figures $21 A$ and $B$ the distinctive thrust fabric has a 
horizontal trace and dips $10^{\circ} \mathrm{N}$., away from the observer. The strong compositional layering that dips toward the northwest (to the left in photograph) is the Precambrian gneissosity that is the dominant structure in the gneiss away from the fault zone. Crystals of microcline perthite form elliptical augen elongated in this Precambrian gneissosity as a result of the Precambrian deformation. Figure $21 B$ shows a closer view of a subhorizontal blastomylonite zone crossing the relict Precambrian gneissosity. A view of this blastomylonite seam in the sawed slab is shown in figure $16 \mathrm{~A}$.

Within $15 \mathrm{~m}$ (50 ft) of the fault zone the original Precambrian gneissosity is destroyed, but partly recrystallized porphyroclasts of granite gneiss remain. Figures $22 A$ and $B$ illustrate the texture of this rock. The porphyroclasts, which resemble tadpoles, swim in a fine-grained matrix of recrystallized plagioclase, microcline, and epidote that is indistinguishable from the material making the blastomylonite seam in figure $21 B$. Whereas the ellipsoidal augen in the Precambrian foliation commonly have axes of $0.5: 1: 10 \mathrm{~cm}$, these new augen are discoidal or only slightly elongated in the plane of the blastomylonitic fabric. Magnetite is abundant in this rock, and it is found either in the matrix or as eyes in a white feldspar augen.

In this section we have described cataclastic and fold fabrics uniquely associated with the thrust faults. As in the case of Paleozoic rocks near the faults, cataclastic processes have greatly reduced the original grain size and have physically destroyed preexisting foliations in Precambrian rocks. Recrystallization along zones of cataclasis has resulted in new minerals that differ from those of the parent rocks. These two processes have produced new rock structures oriented subparallel to observed faults.

We also have pointed out the strong geometric similarity of structural features seen in individual hand specimens and those shown at quadrangle map scale. All available evidence suggests the cataclasis, minor isoclinal folding, blastomylonitic foliation, and recumbent folds are all responses to the same tectonic forces. It is important to note that our evidence strongly suggests isoclinal folding and penetrative shearing may merge with normal metamorphic processes to produce rock textures and structure clearly identifiable in the broad sense as catalastic and more specifically as blastomylonitic.
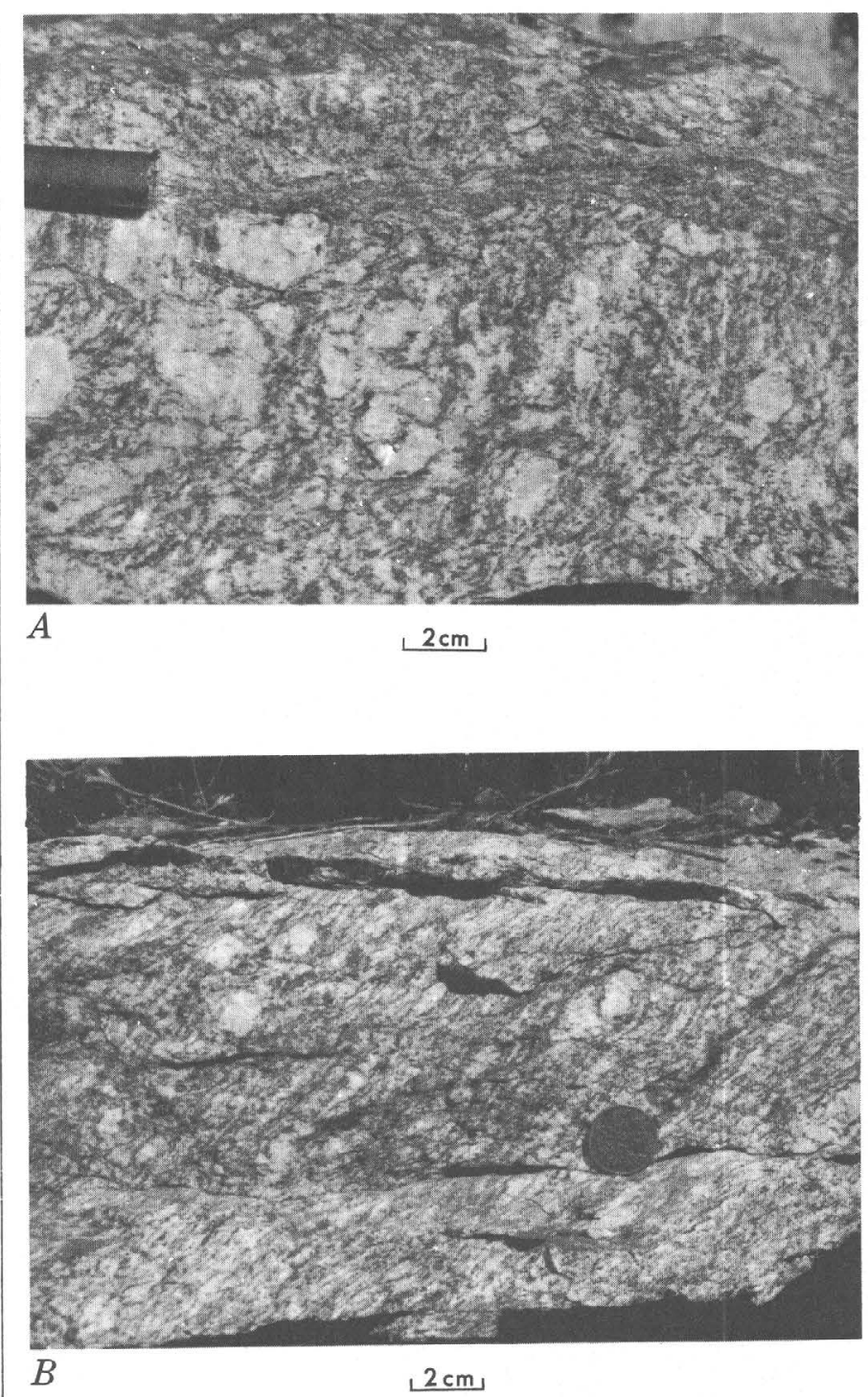

FIGURE 21.-Photographs of Tyringham Gneiss $30 \mathrm{~m}$ above thrust fault. $A$, Blastomylonitic foliation has horizontal trace and dips $10^{\circ} \mathrm{N}$., away from observer: relict Precambrian gneissic foliation dips to northwest (to left in photograph) and contains augen of Precambrian microcline perthite flattened in the gneissic layering, which is a structure typical of the Precambrian gneiss away from fault zones. In fault zones the older gneissosity is destroyed by granulation and recrystallization to a finer grained rock than the parent material. Figures $21 A, B$ and $22 A, B$ illustrate this transition. $B$, Closer view of subhorizontal blastomylonite zone from outcrop in $A$. Bar magnet points to blastomylonite. Within the sheared zone the grain size of the gneiss is reduced to a fine-grained mixture of quartz, muscovite, biotite clinozoisite and abundant sphene. This zone truncates and granulates the coarser grained Precambrian gneissic layering but has a strong fluxion structure and foliation. Augen of microcline perthite originally flattened in the Precambrian foliation (nearly vertical in photograph) are sheared in the blastomylonite zone to produce new augen of smaller size than the original ones that now show an apparent flattening in the nearly horizontal blastomylonitic foliation. 

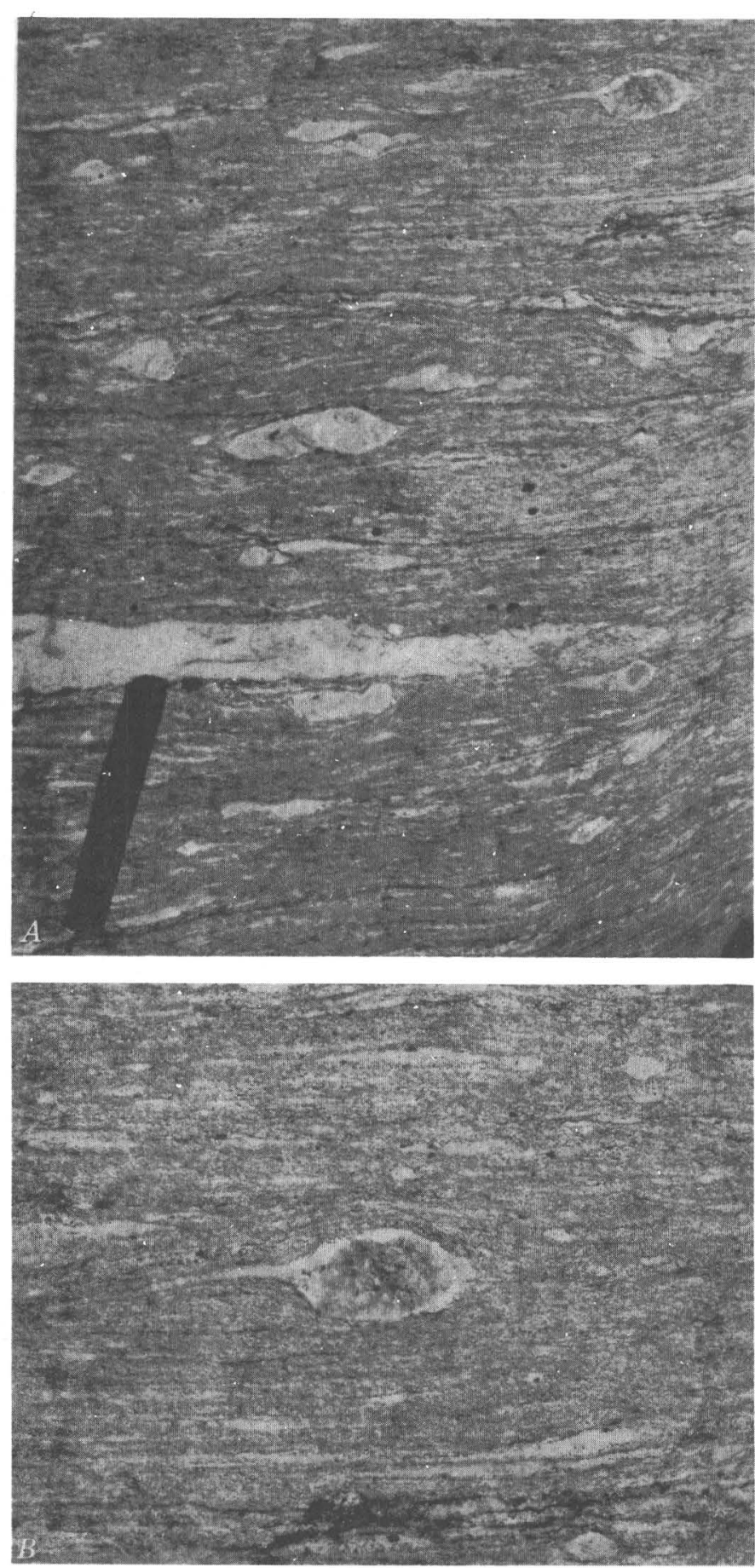

FIGURE 22.-Blastomylonite with porphyroclastic augen of partly recrystallized Tyringham Gneiss. $A$, This photograph illustrates the total destruction of the coarse Precambrian gneissic layering shown in figures $21 A$ and $B$. The dark fine-grained area surrounding the porphyroclasts consists of fine-grained quartz, microcline, clinozoisite, biotite, and sphene. The augen illustrated here are totally remade and reshaped from the original Precambrian augen shown in figures $21 A$ and $B$. Bar magnet $6.5 \mathrm{~cm}$ long. $B$, Close-up view of tadpole-shaped porphyroclast in upper right of $A$. White granular rim and tail are composed of microcline and oligoclase. Small black dots are crystals of magnetite. Augen, with tail $5 \mathrm{~cm}$ long. Fabric appears to be directional.

\section{TEMPORAL RELATIONSHIPS OF RECUMBENT FOLDING, THRUST FAULTING, AND BLASTOMYLONITIC OVERPRINT}

All rocks within the area shown in figure 1 have been affected by a very complex sequence of polyphase deformation and metamorphism. Figure 2 is from previous summaries by Ratcliffe (1969a, b, 1972) and is modified to incorporate the important new information in this paper.

In the early part of this paper we presented data showing that Upper(?) Ordovician to upper Precambrian (?) rocks of the autochthon and overthrust sheets were foliated prior to the basement faulting $\left(\mathrm{F}_{3}\right.$, fig. 2) and the development of the blastomylonitic foliation. These observations are consistent with the field relationships, which indicate a metamorphic fold system $\left(\mathrm{F}_{2}\right)$ in the autochthon is discordantly overlain by the thrust sheets (Ratcliffe, 1969a; 1975 $a$ and $b$ ).

Isoclinal folding $\left(\mathrm{F}_{3}\right)$ associated with the thrust faulting is now recognized over broad areas of figure 1 and is assigned its relative position in figure 2. The thrust faults themselves are folded by two sets of folds that have associated axial planar slip cleavage, crenulation cleavage, or locally, axial planar foliation. The $\mathrm{F}_{4}$ fold system trends northnorthwest and has produced generally upright to southwestward-overturned folds. Porphyroblasts of garnet and staurolite in the western part of figure 1 have inclusion textures that indicate crystallization after or synchronous with the $\mathrm{F}_{4}$ folding. Sillimanite in the eastern part of figure 1 is oriented in the $F_{*}$ axial surfaces. $F_{5}$ folds trend north-northeast and have southeast dipping axial surfaces. Commonly a crenulation cleavage is developed in schistose rocks, and in the eastern part of the map $\mathrm{F}_{5}$ minor folds crenulate sillimanite alined in the $\mathrm{F}_{4}$ axial surfaces.

The available data suggest that the thermal maximum of the high-grade metamorphism postdated the $\mathrm{F}_{3}$ folds and the thrusting, and preceded the northnortheast $F_{5}$ folds. Textures suggest the thermal maximum over most of the area of figure 1 took place during the $\mathrm{F}_{+}$folding event. Therefore, we regard the thermal maximum of the Barrovian-type metamorphism as approximately synchronous with the $\mathrm{F}_{4}$ event.

The absolute dating of events listed in figure 2 is uncertain. However, preliminary isotopic data by R. E. Zartman, U.S. Geological Survey, reported by Harwood (1972) on zircon from a granite stock that crosscuts the blastomylonitic fabric and a thrust slice in the South Sandisfield quadrangle indicate the granite may be Late Ordovician in age and most 
certainly is not Devonian. These results are extremely significant and suggest that events $D_{1}$ to $D_{3}$ are all Late to Middle Ordovician in age and represent different aspects of the Taconic orogeny. Assignment of the Berkshire massif thrusting $\left(\mathrm{D}_{3}\right)$ to the Taconic orogeny differs from the previous interpretations of Ratcliffe $(1969 \mathrm{a}, \mathrm{b}$;) and Norton (1969) which regarded the basement movement as Devonian. Because folds and metamorphic structures like $F_{1}$ and $F_{2}$ are unconformably truncated by Lowermost Devonian or Upper Silurian rock at Mount Ida in the Hudson Valley to the west of figure 1 , these events were previously recognized as Taconic structures (Ratcliffe, 1969b, 1972).

Because Silurian and Lower Devonian rocks to the east of the Berkshire massif have been affected by Barrovian metamorphism as high as sillimanite grade (Thompson and Norton, 1968; Hatch, 1972), $\mathrm{D}_{4}, \mathrm{D}_{5}$, and $\mathrm{D}_{6}$ have been regarded as post-Early Devonian (Ratcliffe, 1969a, b). The granite stock in the South Sandisfield quadrangle, tentatively dated as Late Ordovician, has been metamorphosed and contains a faint north-northeast-trending, nearly vertical foliation parallel to foliation assigned to the $\mathrm{D}_{4}$ event. This supports the hypothesis that $\mathrm{D}_{4}$ and younger events are post-Ordovician and probably post-Early Devonian in age.

On the basis of the available data, we have assigned the features on figure 2 to the Grenville, Taconic, and Acadian orogenies.

\section{REGIONAL SIGNIFICANCE OF BLASTOMYLONITIC FABRIC}

The mylonite gneiss, mylonite schist, and blastomylonite described here provide the first physical evidence of faulting that is independent of map relationships and thus help confirm the existence of the faults. Because the blastomylonitic fabric is parallel to the soles of thrusts and is concentrated and more intensely developed near the thrusts, the mapping of the blastomylonitic foliation provides useful data about the location and attitude of fault surfaces. Likewise, the attitude of blastomylonitic foliation records the effects of subsequent deformation on the thrust slices. This folding recorded by the mapped feature provides a useful tool for identifying the effects of postthrust deformations.

The results of this investigation may be of importance in evaluating the allochthonous versus autochonous nature of other Precambrian rocks in the Appalachians, such as the Housatonic Highlands, Reading Prong, and the Green Mountains. The absence of structures such as those described here may indicate either that the gneisses at other localities are not far transported or that rocks exposed at the surface are too far above buried faults to show such structures. A study of this feature seems very desirable and may yield valuable information regarding the structural history of other massifs in the Appalachians.

Recent geochronologic investigations in western New England and southeastern New York State have verified the existence of an intense, regionally extensive Taconic metamorphic event in the Taconide zone of Zen (1972a). In southeastern New York a post-Middle Ordovician biotite- to sillimanite-grade Barovian zonation is intruded by the Cortlandt Complex Lower Silurian and Upper Ordovician (Long and Kulp, 1962; Ratcliffe, 1968, 1970). Likewise, biotite from the northerly extension of the zonation in Dutchess County, N.Y., yields Taconic-age ${ }^{40} \mathrm{Ar} /{ }^{39} \mathrm{Ar}$ release spectra having plateau ages of 435 and 415 m.y. from staurolite and kyanite zones respectively (Bence and Rajamani, 1972). In addition, Gneisses of the Grenville Series retrograded by Paleozoic metamorphism in the Hudson Highlands, geographically between the two localities cited above, have biotite and hornblende ${ }^{40} \mathrm{Ar} /{ }^{39} \mathrm{Ar}$ release spectra indicative of a Taconicaged remetamorphism (Baker, Dallmeyer, and Sutter, 1973). In the Worcester Mountains of northern Vermont, within the area of geologically demonstrable Acadian overprint, coarse muscovite yields an ${ }^{40} \mathrm{Ar} /{ }^{39} \mathrm{Ar}$ plateau age of $439 \pm 9 \mathrm{~m} . \mathrm{y}$., and hornblende yields a total gas age of $457 \pm 26$ m.y. from garnet-kyanite grade Ordovician rocks. In addition, fine muscovite retrograded from kyanite yields plateau age of $358 \pm 4$ m.y. attributable to the Acadian overprint (Lanphere and Albee, 1974).

It seems likely in the light of recent studies that the Taconic metamorphic effects were much more widely and intensely developed in western New England than is commonly recognized. However, the precise extent and degree of this metamorphism and of the Acadian overprint is largely unresolved at present.

If we have correctly assigned the basement thrusting and blastomylonite to the Late Ordovician, as the age of the granite indicates, this is one more bit of evidence indicating the Taconic orogenic event in western New England and New York State produced genuine orthotectonic deformation, as suggested by Ratcliffe $(1969 a, b, 1968,1970)$ and by Zen $(1972 a, b)$. Taconic deformation in the area of the Berkshire massif would then compare favorably in intensity of deformation and extent of mobiliza- 
tion of basement rocks with the infrastructure of larger mountain belts, such as in the Pennine realm of the Swiss Alps.

\section{REFERENCES CITED}

Alavi, Mehdi, 1971, The bedrock geology of part of the Pittsfield East quadrangle, Massachusetts: City College of New York, M. A. Thesis, $69 \mathrm{p}$.

Baker, J. D., Dallmeyer, R. D., and Sutter, J. F., 1973, Significance of differences between ${ }^{40} \mathrm{Ar} /{ }^{30} \mathrm{Ar}$ and $\mathrm{K}$ Ar uplift ages of the northernmost Reading Prong, New YorkNew Jersey [abs.]: Geol. Soc. America Abs. with Programs, v. 5 , no. 7 , p. 540.

Bence, A. E., and Rajammani, V., 1972, ${ }^{40} \mathrm{Ar} /{ }^{39} \mathrm{Ar}$ incremental heating "ages" of muscovites and biotites from a progressive metamorphic terrain: [Abs.]: Geol. Soc. America, Abs. with Programs, v. 4, no. 7, p. 449.

Donath, F. A., Faill, R. T., and Tobin, D. G., 1971, Deformational mode fields in experimentally deformed rock; Geol. Soc. America Bull., v. 82, no. 6, p. 1441-1461.

Emerson, B. K., 1898, Geology of old Hampshire County, Massachusetts, comprising Franklin, Hampshire, and Hampden Counties: U.S. Geol. Survey Mon. 29, 790 p.

Harwood, D. S., 1971, Recumbent folding and southwestward thrusting of Precambrian and Lower Paleozoic rocks in the South Sandisfield quadrangle, Massachusetts and Connecticut [abs.]: Geol. Soc. America Abs. with Programs, v. 3 , no. 1 , p. $36-37$.

1972, Tectonic events in the southwestern part of the Berkshire anticlinorium, Massachusetts and Connecticut [abs.]: Geol. Soc. America Abs. with Programs, v. 4, no. 1, p. 19.

Hatch, N. L., Jr., 1972, Tectonic history of part of the east limb of the Berkshire anticlinorium, Massachusetts [abs.]: Geol. Soc. America Abs. with Programs, v. 4, no. 1, p. 19.

Higgins, M. W., 1971, Catalastic rocks: U.S. Geol. Survey Prof. Paper 687, 97 p.

Lanphere, M. A., and Albee, A. L., $1974,{ }^{40} \mathrm{Ar} /{ }^{30} \mathrm{Ar}$ age measurements in the Worcester Mountains: evidence of Ordovician and Devonian metamorphic events in northern Vermont: Amer. Jour. Sci., v. 274, p. 545-555.

Long, L. E., and Kulp, J. L., 1962, Isotopic age study of the metamorphic history of the Manhattan and Reading Prongs: Geol. Soc. America Bull., v. 78, p. 969-996.

Norton, S. A., 1969, Unconformities at the northern end of the Berkshire Highlands, in Bird, J. M., ed., Guidebook for field trips in New York, Massachusetts, and Vermont, New England Intercollegiate Geol. Conf. 61st Ann. Mtg. Albany, New York, 1969: Albany, New York SUNY-A Bookstore p. 21-1-21-20.
Ratcliffe, N. M., 1968, Contact relations of the Cortlandt Complex at Stony Point, New York, and their regional implications: Geol. Soc. America Bull., v. 79, no. 6, p. 777-786.

1969a, Structural and stratigraphic relations along the Precambrian front in southwestern Massachusetts, in Bird, J. M. ed., Guidebook for field trips in New York, Massachusetts, and Vermont, New England Intercollegiate Geol. Conf. 61st Ann. Mtg. Albany, New York; 1969: Albany, New York, SUNY-A Bookstore, p. 1-1-1-21.

$1969 \mathrm{~b}$, Stratigraphy and deformational history of rocks of the Taconic Range near Great Barrington, Massachusetts, in Bird, J. M., ed, Guidebook for field trips in New York, Massachusetts, and Vermont, New England Intercollegiate Geol. Conf. 61st Ann. Mtg. Albany, New York, 1969: Albany, New York, SUNY-A Bookstore, p. 2-12-23.

1970, Ancient strike slip fault tectonics in the Hudson Highland and Manhattan Prong: New York Acad. Sci., Trans. ser. 2, v. 32, no. 8, p. 1009-1021.

1972, Revised polyphase structural chronology in western Massachusetts and problems of regional correlation [abs.]: Geol. Soc. America Abs. with Programs, v. 4, no. 1, p. 40.

1975a, Bedrock geologic map of the Great Barrington quadrangle, Massachusetts: U.S. Geol. Survey. Map GQ1141. (In press.)

1975b, Bedrock geologic map of the Stockbridge quadrangle, Massachusetts: U.S. Geol. Survey Geol. Quad. Map GQ-1143. (In press).

Ratcliffe, N. M., and Harwood, D. S., 1971, Structural geology of the western edge of the Berkshire massif, southwestern Massachusetts and Connecticut [abs.]: Geol. Soc. America Abs. with Programs, v. 3, no. 1 p. 49-50.

Ratcliffe, N. M., and Zartman, R. E., 1971, Precambrian granitic plutonism and deformation in the Berkshire massif of western Massachusetts [abs.]: Geol. Soc. America Abs. with Programs, v. 3, no. 1, p. 49.

Thompson, J. B., Jr., and Norton, S. A., 1968, Paleozoic regional metamorphism in New England and adjacent areas, in Zen, E-an, White, W. S., Hadley, J. B., and Thompson, J. B., Jr., eds., Studies of Appalachian geologynorthern and maritime: New York, Interscience Pub., p. 319-327.

Zen, E-an, 1972a, The Taconide zone and the Taconic orogeny in the western part of the northern Appalachian orogen: Geol. Soc. America, Spec. Paper 135, 72 p.

$1972 \mathrm{~b}$, Some revisions in the interpretation of the Taconic allochthon in west-central Vermont: Geol. Soc. America Bull., v. 83, no. 9, p. 2573-2588.

Zen, E-an, and Ratcliffe, N. M., 1971, Bedrock geologic map of the Egremont quadrangle and adjacent areas, Berkshire County, Massachusetts, and Columbia County, New York: U.S. Geol. Survey Misc. Geol. Inv. Map I-628. 



\section{Chronology of Paleozoic Tectonic}

and Thermal Metamorphic Events in Ordovician, Cambrian, and Precambrian Rocks at the North End of the Berkshire Massif, Massachusetts

By STEPHEN A. NORTON

TECTONIC STUDIES OF THE BERKSHIRE MASSIF, WESTERN MASSAGHUSETTS, CONNECTICUT, AND VERMONT

GEOLOGICAL SURVEY PROFESSIONAL PAPER $888-B$

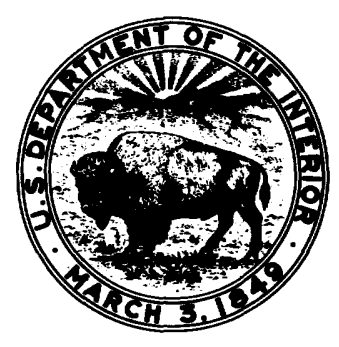





\section{CONTENTS}

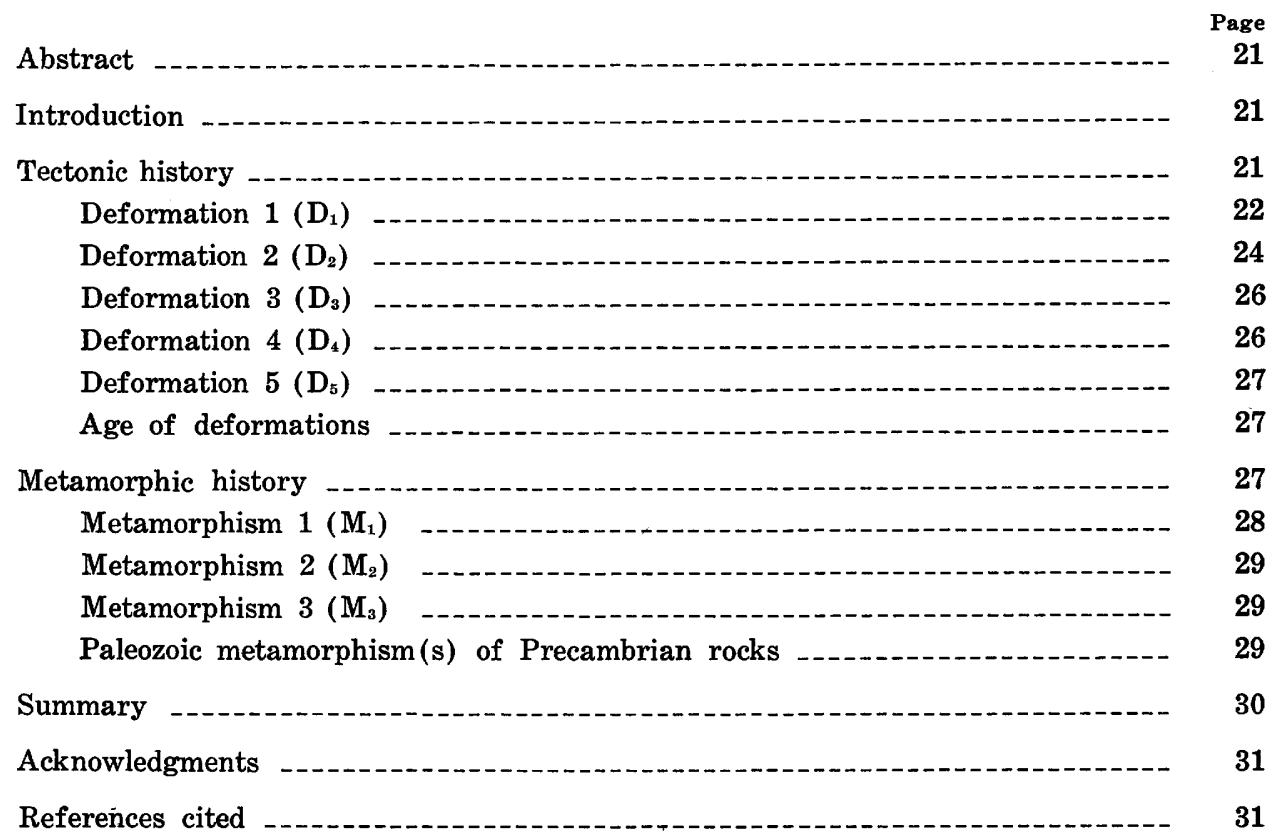

\section{ILLUSTRATIONS}

Figure 23. Index map of west-central New England showing location and geologic setting of study area

24. Generalized geologic map of the study area

25. East-west cross sections at the southeast corner of the Becket quadrangle and in the central part of the Peru quadrangle --.---

26. Photomicrographs showing different age relationships between metamorphisms and deformations -

27. Photomicrographs showing the effects of Paleozoic metamorphisms and deformations on Precambrian rocks 



\title{
CHRONOLOGY OF PALEOZOIC TECTONIC AND THERMAL METAMORPHIC EVENTS IN ORDOVICIAN, CAMBRIAN, AND PRECAMBRIAN ROCKS AT THE NORTH END OF THE BERKSHIRE MASSIF, MASSACHUSETTS
}

\author{
By Stephen A. Norton ${ }^{1}$
}

\begin{abstract}
The north end of the Berkshire massif is a Precambrian gneiss terrane flanked to the west by Ordovician and Cambrian miogeosynclinal metasedimentary rocks and to the east by eugeosynclinal metasedimentary rocks ranging in age from Devonian to Cambrian. These two Paleozoic rock sequences are in thrust fault contact to the north.

Four stages of regional deformation are recognized in this area. $D_{1}$, of Taconic age, produced large-scale east-over-west thrust faults and related folds in the eugeosynclinal, Precambrian, and miogeosynclinal rocks. At least two distinct sets of thrust faults were developed within the Precambrian terrane, a north-trending set (later) and a northwest-trending set (earlier?). Eastward in eugeosynclinal rocks, $D_{1}$ was less intense, producing small-scale isoclinal folds. $D_{2}$ formed small open folds in miogeosynclinal rocks, isoclinal small folds in eugeosynclinal rocks, and locally openly refolded Precambrian rocks. The transition in style of $D_{2}$ occurs at the north end of the massif. $D_{3}$ formed small to large open northwest- to northeast-trending folds in the eugeosynclinal rocks and locally refolded only the eastern part of the Precambrian terrane. $\mathrm{D}_{4}$ formed small crinkles and small- to large-scale warps, very rarely with axial-surface cleavage. $D_{2}, D_{3}$, and $D_{4}$, are probably Acadian. $D_{5}$, of unknown age, produced high angle faulting.

Regional metamorphism $\left(M_{1}\right)$, having a maximum intensity to the west of the Precambrian terrane, reached garnet grade during $D_{1}$. A second regional garnet-grade metamorphism $\left(M_{2}\right)$ was most intense east of the Precambrian terrane and accompanied $D_{2}$. A third regional metamorphism $\left(M_{3}\right)$ reached sillimanite grade in eugeosynclinal rocks just prior to $D_{3} . M_{1}$, $M_{2}$, and $M_{3}$ produced retrograde metamorphism within the Precambrian terrane. $M_{2}$ and $M_{3}$ produced minor retrograde effects in the miogeosynclinal rocks.

The locus of most intense deformation and highest grade metamorphism appears to have migrated eastward with time.
\end{abstract}

\section{INTRODUCTION}

This report describes the tectonic and metamorphic history of the three $71 / 2$-minute quadrangles outlined in figure 23, at the north end of the Berk-

\footnotetext{
1 Univ. of Maine, Orono, Maine.
}

shire massif. Additionally, the writer has shared in the mapping of 3 other quadrangles further east and some observations herein are drawn from this other work.

Stratigraphically the area is divided into three regions. The northwest part is underlain by a miogeosynclinal clastic-carbonate sequence, ranging in age from Middle Ordovician to Early Cambrian, overlain unconformably by pelitic rocks of Middle Ordovician age more typical of the eugeosynclinal facies. Descriptions of these rocks are available in Herz $(1958,1961)$ and Norton (1967). The central area is underlain by Precambrian metasedimentary, metavolcanic, and metaigneous rocks of varied types (Norton, 1967). The eastern part of the area is underlain by a typical eugeosynclinal sequence of metamorphosed shales, graywackes, minor carbonaceous quartzite, and felsic to mafic volcanic rocks. Intrusive igneous rocks include ultramafic bodies, one granite body, and one metadiorite body. Descriptions of these rocks may be found in Hatch and others (1967).

\section{TECTONIC HISTORY}

Figure 24 is a generalized geologic map of the study area outlined on figure 23. Because of the widely differing orientations of bedding and foliation caused by the earliest deformation, orientation of minor structures produced by subsequent episodes of deformation vary greatly from place to place. Thus, correlation of structural episodes over large distances is difficult, but a sequence of deformations has been determined from:

1. Multiply deformed planar features such as folded bedding, foliation, and folds. 


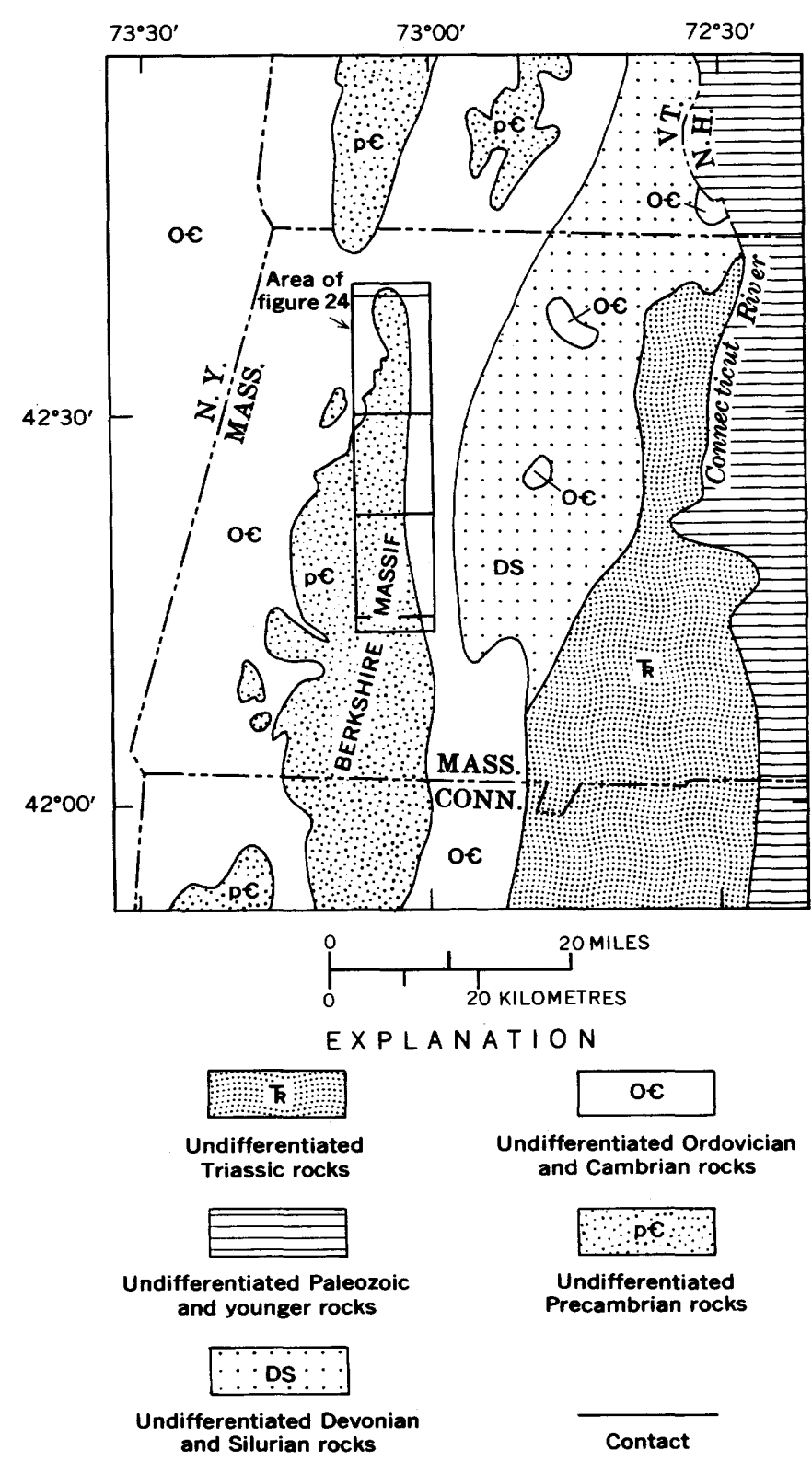

Figure 23.-Index map of west-central New England showing location and geologic setting of study area.

2. Style of folding and resultant foliation surfaces.

3. Intensity of fabrics developed during deformation.

4. Direction of transport, deduced from asymmetry of folds.

5. Relationship of tectonic structures to prograde and retrograde porphyroblasts.

Four regional stages of folding are interpreted for this area. A fifth stage of brittle regional deformation has been recognized. Each regional deformational event will be discussed as it is developed in the northwest (henceforth area 1, miogeosynclinal rocks); in the central area (henceforth area
2, Precambrian rocks) ; and to the east (henceforth area 3, eugeosynclinal rocks).

\section{DEFORMATION 1 ( ${\left(D_{1}\right)}^{\prime}$}

The earliest recognized major and minor structures in area 1 (fig. 24) are designated $D_{1}$ structures. Major structures consist of large-amplitude recumbent and isoclinal folds associated with the Hoosac nappe (fig. 24), which has a southern limit in the central part of the Windsor quadrangle and extends northward at least $3.2 \mathrm{~km}(2$ mile) beyond the map. The inverted limbs of recumbent folds are locally sheared out in thrusts which developed during the $D_{1}$ deformation. Both large- and small-scale features suggest east-over-west transport. A strong schistosity is parallel to the thrusts and axial surfaces of these folds.

West of the Windsor quadrangle, in the Cheshire quadrangle, Herz (1958) recognized both thrusts and folded thrusts, interpreted by this writer to be of $D_{1}$ age because later deformations to the east were of small scale.

Further south on the west side of the Berkshire massif, Ratcliffe and Harwood (1975) recognize an earlier foliation in the Paleozoic rocks which is in turn deformed by a fold-thrust fabric equivalent to the pervasive schistosity of area 1 . This earlier foliation has not been generally recognized by this writer in area 1.

Several lines of evidence, however, suggest an earlier (than $D_{1}$ ) deformation. (A) Several outcrops of marble have isoclinal folds which fold a lineation that is at slight angles to the axis of the fold. This could represent two nearly coaxial deformations or one continuous event with slightly varying stress orientation. (B) In the Hoosac Formation schists, there are numerous microscopic to 2-cm-thick layers of nearly pure quartz. They are essentially parallel to bedding but are very discontinuous. They may be beds themselves or, alternatively, they may have a tectonic origin. $\mathrm{D}_{2}$ folds in these same schists are open. They fold schistosity and commonly have very thin to 2-cm-thick layers of nearly pure quartz developed parallel to axial-plane cleavage and in axialplane faults. The quartz lenses parallel to $D_{1}$ schistosity may have originated in a similar mannerby pre- $\mathrm{D}_{1}$ deformation and then isoclinal folding by $D_{1}$. (C) Rarely, in the more schistose parts of the Hoosac Formation west of the Precambrian terrane, a penetrative foliation, a spaced schistosity composed of muscovite, parallel to $D_{1}$ axial surfaces, cuts an earlier schistosity composed of muscovite and 


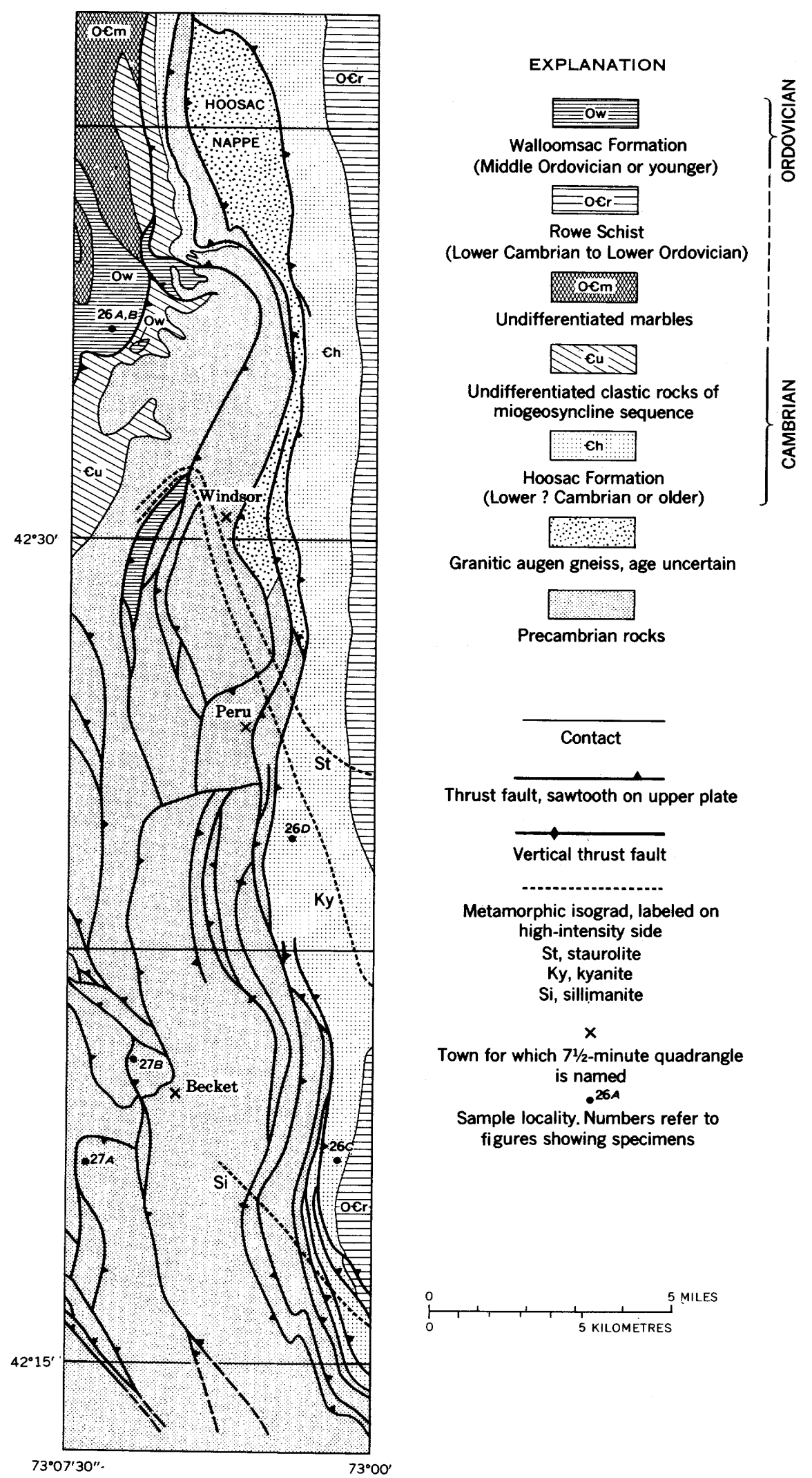

Figure 24.-Generalized geologic map of the study area. The south end of the north Adams quadrangle (Herz, 1961) and the north end of the Otis quadrangle are included along with the Windsor, Peru, and Becket quadrangles. 
biotite. Both of these schistosities are in turn deformed by later tectonic episodes.

Minor $D_{1}$ fold axes in area 1 trend N. $10^{\circ} \mathrm{W}$. to N. $10^{\circ} \mathrm{E}$. and are subhorizontal or plunge as much as $20^{\circ}$. The plunge of the axes and the strike and the dip of axial surfaces are variable locally and regionally because of refolding, particularly to the east.

Eastward, at the north end of figure $24, D_{1}$ folds and schistosity dip more steeply, and the plunges are less systematic.

The $D_{1}$ folds and faults have been traced southeastward across the Windsor quadrangle. Along the east edge of the Precambrian terrane, Precambrian rocks and the Hoosac Formation (Lower Cambrian or older) (dominantly schists) are intercalated on a very small to large scale (fig. 25). Here the Precambrian rocks are dominantly feldspathic gneisses, commonly with strong compositional banding which is nonparallel to the pervasive regional $\mathrm{D}_{1}$ schistosity in the adjacent schists. There is no stratigraphic symmetry across these bands, ruling out folding as an explanation for the interlayering. At and near the contacts, the fabrics within the Precambrian rocks are obliterated by a cataclastic foliation parallel to the $D_{1}$ schistosity in the schists. These relationships are interpreted to indicate the Middlefield thrust zone, a zone of tectonic intercalation and décollement (fig. 25) along the east margin of the Berkshire massif (Norton, 1971) (for an alternative interpretation, see Gates and others, 1973). At the southeast corner of figure 24 , at least one of these faults cuts up through more than a mile thickness, including several stratigraphic members of the Hoosac Formation, and causes an intercalation of the Hoosac Formation and overlying Rowe Schist.

Minor structures in the schists consist of a strong regional steeply east-dipping axial-surface schistosity parallel to small-scale north-trending isoclinal folds. Plunges of axes range from horizontal to down dip to the east; the latter are more common. Eastward and southward, $D_{1}$ foliation and minor structures are obscured and even obliterated by later deformation (especially $\mathrm{D}_{2}$ ).

Within the Precambrian terrane, area 2, the dominant structures consist of isoclinal and locally recumbent folds, commonly with easterly striking axes. Axi ll-plane foliation is commonly developed in more schistose units. Folds range in scale from microscopic to several hundred metres in amplitude. The age of these structures is believed to be Grenville.
The attitude and distribution of the Precambrian rocks were strongly modified by Paleozoic events, particularly near the Cambrian-Precambrian contacts. $D_{1}$ deformation produced, in addition to the faulting, small- to large-scale refolding of Precambrian structures. Axial surfaces of these folds trend north; dips range from $45^{\circ} \mathrm{W}$. to $45^{\circ} \mathrm{E}$.; axes plunge gently north or south. Map-scale refolded structures are most clearly seen in the central and north-central parts of the Becket quadrangle and the south-central part of the Peru quadrangle (fig. 24).

Several major faults within the Precambrian terrane cut the Precambrian structures. The faults are marked by zones as much as $30.5 \mathrm{~m}$ (100 ft) thick of transposed, sheared, highly folded, and crushed gneisses having a pronounced foliation caused by recrystallization of, most commonly, biotite parallel to the plane of shearing. Quartz and feldspar grains are crushed and strung out in trains, also parallel to the biotite. The faults at the east edge of the Precambrian trend northerly and dip steeply to the east. Within the Precambrian terrane there are two major sets of faults; a north-trending set and an older northwest-trending set. Several of the more easterly faults within the Precambrian terrane have thin septa $(0$ to $10 \mathrm{~m})$ of schist closely resembling Hoosac schist, further east (fig. 24). Two of these septa have been traced more than $4 \mathrm{~km}$. The schistosity in these septa is generally parallel to the fault surfaces but locally is contorted and even truncated by the gneisses. The dip of several faults reverses along strike. These two observations suggest that the schist had a foliation prior to or during faulting and that folding continued after faulting was completed.

It has not been established in the Precambrian area of figure 25 whether there were two or more distinct $D_{1}$ events (such as is postulated for area 1) or one continuous sequence of thrusts and related folds.

\section{DEFORMATION $2\left(\mathrm{D}_{2}\right)$}

In area 1 , small-scale folds deform bedding and foliation and are designated $D_{2}$. The folds are open crinkles in pelitic parts of the psammitic units (Dalton Formation), chevron style in the pelites (Walloomsac and Hoosac), and warps in the marble units. Axial surfaces generally trend northerly and dip easterly about $45^{\circ}$; axes generally plunge gently north or south. The axes of $D_{2}$ folds are nearly cylindrical with those of $D_{1}$ in area 1 , except where $\mathrm{D}_{1}$ foliation (and bedding) was not approximately flat lying. In those areas, $\mathrm{D}_{2}$ axes are locally variable, depending not only on lithology but also on the orien- 

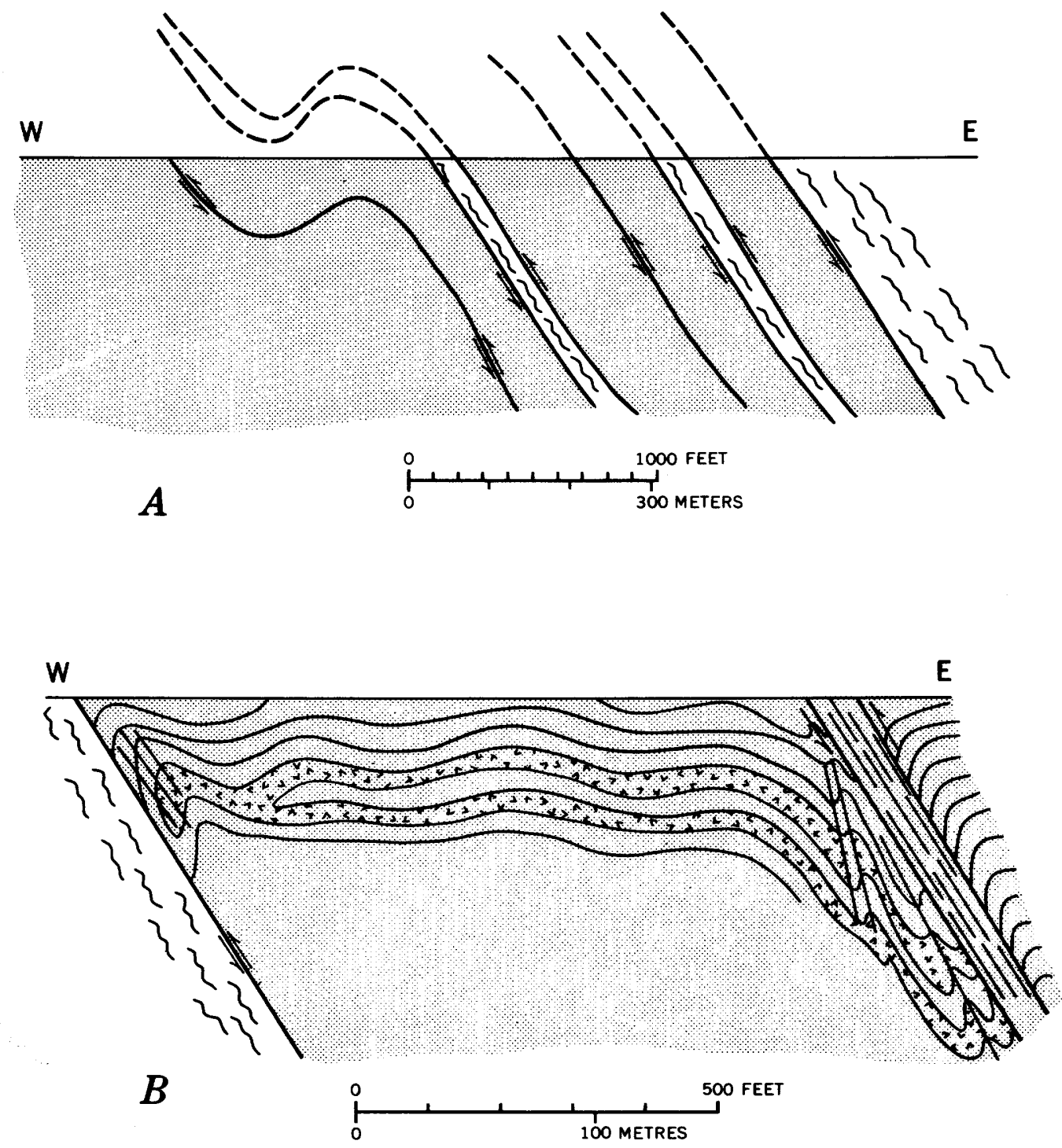

EXPLANATION
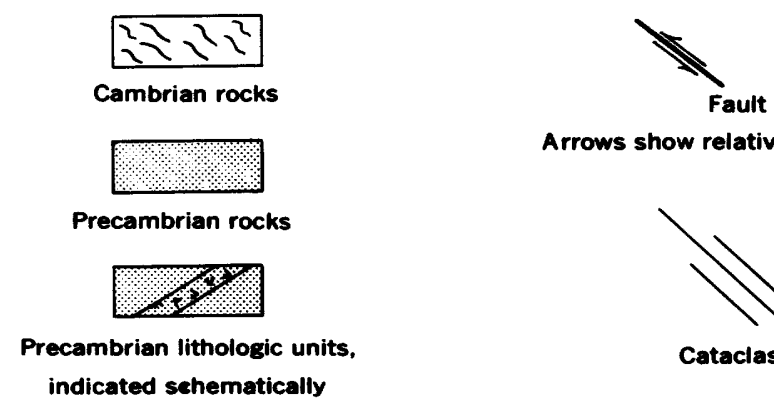

Arrows show relative movement indicated sehematically

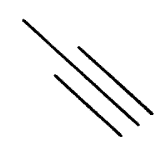

Cataclasis

Figure 25.-East-west cross sections, $A$, at the southeast corner of the Becket quadrangle showing typical intercalation of Cambrian and Precambrian rocks in the Middlefield thrust zone along the eastern margin of the Berkshire massif and, $B$, in the central part of the Peru quadrangle showing refolding and cataclasis of the probable Precambrian recumbent folds in Precambrian rocks in the Middlefield thrust zone. 
tation of the folded surface prior to $D_{2}$. The asymmetry of the folds is consistently indicative of an east-over-west shear. Axial-plane cleavage is rarely developed in the pelitic rocks. Locally, within the albite schist of the Hoosac Formation in the central part of the North Adams quadrangle (Herz, 1961), axial surfaces are marked by microscopic to 2-cmthick layers of quartz with minor calcite and chlorite. Locally these folds pass along strike and up or down dip into north-trending $45^{\circ}$ E.-dipping faults, commonly with quartz veins parallel to and within the fault.

At the northwesternmost exposures of the Hoosac Formation in figure 24, $\mathrm{D}_{2}$ structures are only found in isolated outcrops. Eastward the frequency of occurrence and intensity of $\mathrm{D}_{2}$ structures increase. At the eastern limit of the Hoosac in the North Adams quadrangle, $D_{1}$ and $D_{2}$ are of nearly equal intensity. There, small-scale $\mathrm{D}_{2}$ folds commonly have a strong slip cleavage and locally a schistosity.

Eastward from area 1, the northeast or southeast plunge of $\mathrm{D}_{2}$ axes increases along with the dip of axial surfaces which, except where refolded, ranges from $30^{\circ}$ to $90^{\circ} \mathrm{E}$. The sense of transport is east over west, as is true for $D_{1}$. Fold style ranges from open to isoclinal. $D_{2}$ folds are all intraformational with amplitudes of as much as a few metres. The intensity of $\mathrm{D}_{2}$ structures increases in a southeasterly direction, and $D_{1}$ foliation and folds are nearly obliterated but are locally preserved between widely spaced $\mathrm{D}_{2}$ foliation surfaces. The two intersecting foliations, most commonly seen in the Rowe Schist, yield an anastomosing foliation and a steeply plunging lineation. East of the Precambrian terrane the regional schistosity trend is north, is steeply east dipping, and is composed of two nearly parallel schistosities, $D_{1}$ and $D_{2}$, with the latter dominating.

Locally, $\mathrm{D}_{2}$ folds deform the eastern CambrianPrecambrian contact and fold schistosity and cataclastic textures in the respective rocks, but generally the regional map pattern in area 2 is not affected by these folds. $D_{2}$ minor structures have not been recognized far into the Precambrian terrane. Recognition of $\mathrm{D}_{2}$ structures is difficult because $\mathrm{D}_{2}$ regional schistosity is essentially parallel to $D_{1}$ schistosity and the direction of transport was essentially the same.

\section{DEFORMATION 3 ( $\left.D_{\mathrm{s}}\right)$}

In the north-central part of figure $24, D_{1}$ and $D_{2}$ structures are deformed by northeast- and northwest-trending folds with steeply dipping axial surfaces. Dips range from west to east. Northeasttrending folds generally plunge northeast (where
$D_{1}$ and $D_{2}$ schistosities dip east) and northwest folds generally plunge southeast. Folds are tight to open and are accompanied generally by axial-plane cleavage and kink banding in the more schistose rocks. Just west of the northeast corner of figure 24, in the Hoosac Formation, small tight $\mathrm{D}_{3}$ folds pass along the strike of the axial surface into open faults, marked by bull quartz and quartz-garnet or quartzhornblende veins. These folds and faults deform $D_{2}$ schistosity but do not have an associated penetrative foliation.

Southward and eastward (in area 3 ), $\mathrm{D}_{3}$ folds are more intense and larger scale. Folds of this generation generally do not deflect map units except near Blandford, Massachusetts (see Hatch, 1975, and Stanley, 1975), and in the southeast corner of figure 24 where there is a $1.6-\mathrm{km}$ (1-mile) deflection in the Cambrian-Precambrian contact. In small folds the shear sense is generally left handed but the shear sense reverses across the axial surface of larger folds of this generation, particularly where the limbs dip shallowly.

Nearly all $\mathrm{D}_{3}$ folds east of the Precambrian rocks in the Peru and Becket quadrangles (fig.25) trend northeast, plunge northeast, and dip steeply to the northwest or southeast. No penetrative schistosity is associated with these folds.

$\mathrm{D}_{3}$ minor structures have not been recognized within the Precambrian terrane (area 2). Locally, along the eastern margin of the Precambrian, axialsurface $\mathrm{D}_{3}$ slip cleavage in the Hoosac schists passes laterally into small, commonly quartz-filled faults in the more competent Precambrian rocks.

Although $D_{3}$ folds are found throughout the Hoosac Formation and Rowe Schist, they are much more common near the Cambrian-Precambrian boundary.

\section{DEFORMATION $4\left(\mathrm{D}_{4}\right)$}

Throughout the area underlain by Paleozoic rocks in figure 24, north-trending warps and crinkles, designated $\mathrm{D}_{4}$, locally fold all previous structures and all metamorphic minerals. In the western part of the Windsor quadrangle, some folds designated $\mathrm{D}_{4}$ may be $\mathrm{D}_{3}$ but the strike of $\mathrm{D}_{3}$ folds further north and east makes this unlikely. Warps with wavelengths of several metres and crinkles ranging from a few centimetres to microscopic are most common. Generally north-trending axes have plunges ranging from $0^{\circ}$ to $20^{\circ} \mathrm{N}$. or S., depending upon the original orientation of the folded surface prior to $D_{4}$ folding. Dips of axial surfaces are steep to vertical, also depending upon the orientation of the folded surface. 
These structures are most plentiful and intense at the north-central end of figure 24 where, rarely, $D_{4}$ axial-surface cleavage is developed. Southward, $\mathrm{D}_{4}$ folds become rarer and less intense. No prograde metamorphic minerals are associated with $\mathrm{D}_{4}$, and foliation-producing minerals including muscovite, paragonite, chlorite, chloritoid, and biotite still show undulose extinction where they are folded by $\mathrm{D}_{4}$.

$\mathrm{D}_{4}$ structures have not been recognized in the Precambrian rocks. If present, they probably are of such a large scale that they cannot be sorted out from some of the $L_{1}$ and $D_{2}$ folding, with which $D_{4}$ is cylindrical. The map pattern of the $\mathrm{D}_{1}$ thrust faults in the Windsor quadrangle (fig. 24) suggests the possibility of a large north-trending fold $\left(\mathrm{D}_{4}\right.$ ?) which has arched the thrust plates.

DEFORMATION 5 (

Throughout the study area, numerous small faults have been observed in outcrops but have not been traced any appreciable distance. They are generally north-trending and have steep to vertical dips.

Three areas have been mapped where extensive fault gouge and breccia are present.

1. A zone of unrecrystallized gouge, including bright brick-red material, is coincident with the eastern $D_{1}$ fault bounding the Walloomsac inlier in the northwestern corner of the Peru quadrangle. The extension of this zone is not known.

2. The eastern $D_{1}$ thrust fault bounding the Precambrian in the central part of the Windsor quadrangle is the locus of a breccia zone about $60 \mathrm{~m}$ thick. The breccia is unrecrystallized and has minor sulfide mineralization and quartz veins. This zone may connect with the zone described above, (1), but relationships are unclear.

3. A series of outcrops of breccia coincident with the westernmost $D_{1}$ thrust in the Windsor and Peru quadrangles has zones as much as $30.5 \mathrm{~m}$ $(100 \mathrm{ft})$ wide of Cheshire Quartzite fragments cemented by iron oxides. The fault plane has not been observed and the displacement is not known for certain but appears to be less than

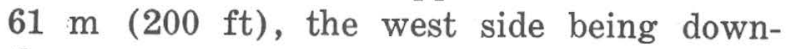
thrown.

\section{AGE OF DEFORMATIONS}

$\mathrm{D}_{1}$ through $\mathrm{D}_{5}$ deform rocks ranging in age from Precambrian (Norton, 1967; Harwood, 1972; Ratcliffe and Zartman, 1971) to Middle Ordovician (Hatch, 1967) and are thus younger than this.
Harwood (1972), in an area $40 \mathrm{~km}$ (25 miles) to the south-southwest of figure 24 , on the west side of the Precambrian terrane, gives a Late Ordovician age (Taconic) for a granite which cuts a thrust fault of similar style and orientation to the western $\mathrm{D}_{1}$ thrusts of this report. Similar structures have been mapped in the intervening area by Ratcliffe (Ratcliffe and Harwood, 1975). Thus $\mathrm{D}_{1}$ structures of this report are correlated with the thrust plates of Harwood and assigned a Late Ordovician age (Taconic).

$\mathrm{D}_{2}$ and $\mathrm{D}_{3}$ structures deform rocks as young as Early Devonian. Both of these deformations have, at least locally, a penetrative foliation developed during concurrent metamorphism (see below). K-Ar and $\mathrm{Rb}-\mathrm{Sr}$ radiogenic dating of biotite from the Middlefield Granite (Hatch and others, 1970), which has a $\mathrm{D}_{2}$ foliation, yielded an age of about $360 \mathrm{~m}$.y. If this date is a cooling date after metamorphism associated with $D_{3}$, then $D_{2}$ and $D_{3}$ are probably Middle to Early Devonian in age (Acadian).

$\mathrm{D}_{4}$ and $\mathrm{D}_{5}$ clearly postdate all prograde metamorphism and are thus younger than Middle Devonian. The orientation of $\mathrm{D}_{5}$ fault zones and the presence of red gouge suggests the possibility that $D_{5}$ structures may be related to the Triassic faulting which formed a large graben to the east (the Connecticut River valley) (Robinson, 1967) and a smaller graben to the south in Connecticut (Stanley, 1968).

\section{METAMORPHIC HISTORY}

The area of figure 24 has been subjected to at least three periods of regional prograde metamorphism interspersed with the first three tectonic events discussed above. The staurolite, kyanite, and sillimanite isograds shown on figure 24 are based on the distribution of the highest grade porphyroblasts in Paleozoic rocks, regardless of specific age. Overprints of later and higher grade metamorphism may have erased the evidence of earlier and lower grade events, particularly where the earlier and lower events were static thermal metamorphisms.

Criteria for recognizing time relationships between tectonic and metamorphic events include:

1. Sigmoidally arranged inclusions in prograde porphyroblasts (presumed to be synkinematic).

2. Undeformed trains of inclusions in porphyroblasts which presumably indicate static growth.

3. Deflection of fabrics (for example, kink bands) around porphyroblasts, particularly garnets.

4. Crosscutting relationships between schistosity and porphyroblasts. 
5. Porphyroblasts that include $s$ surfaces or hinges of folds.

6. Deformed porphyroblasts.

\section{METAMORPHISM $1\left(M_{1}\right)$}

The earliest metamorphism recognized west of the Precambrian (fig. 24) is designated $\mathrm{M}_{1}$. There, in pelitic rocks, trains of small porphyroblasts of

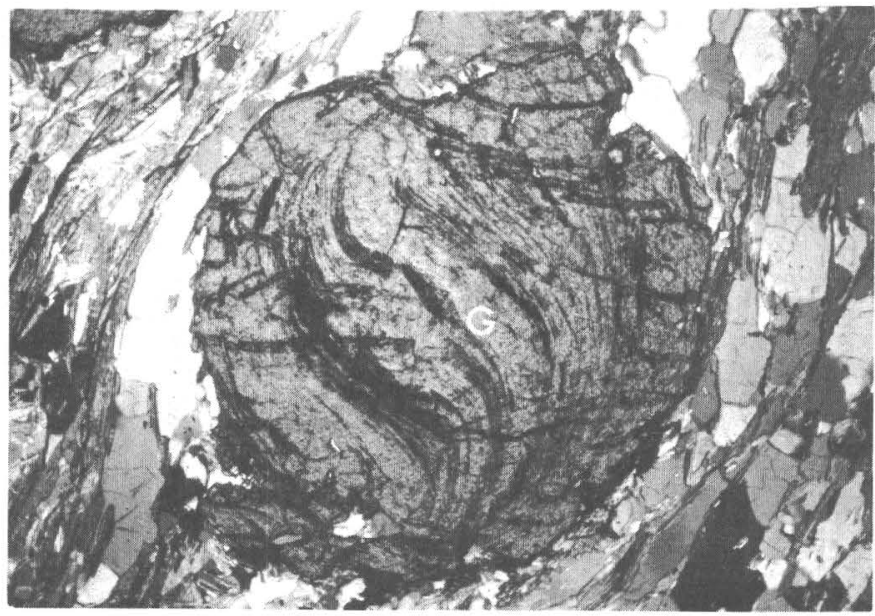

$A$ $0.6 \mathrm{~mm}$

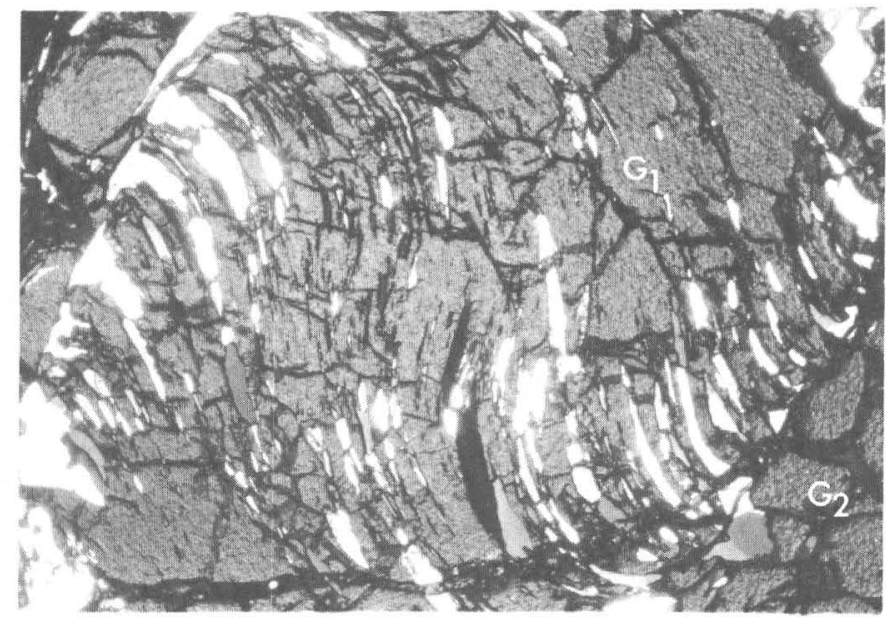

$C$ $0.4 \mathrm{~mm}$ quartz, biotite, chlorite, graphite, muscovite, and chloritoid are arranged in a sigmoid pattern within garnet porphyroblasts (fig. 26A). The trains are continuous into the regional schistosity associated with $\mathrm{D}_{1}$. The axis of rotation of the sigmoid structures is parallel to $D_{1}$ fold axes. Locally, and in the same hand specimen, other garnets are free of sigmoidally arranged inclusions and crosscut the $D_{1}$ schistosity.

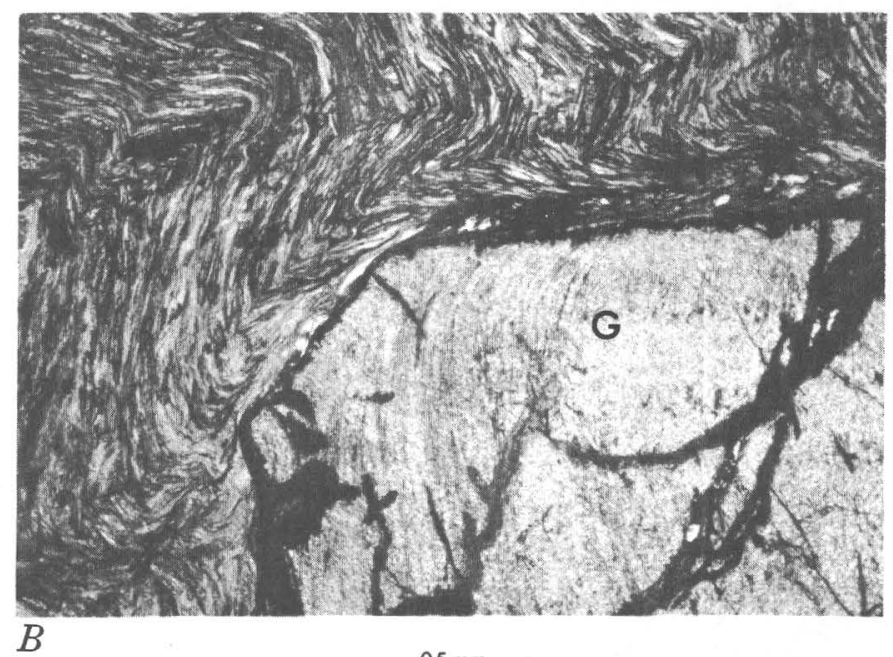

$B$
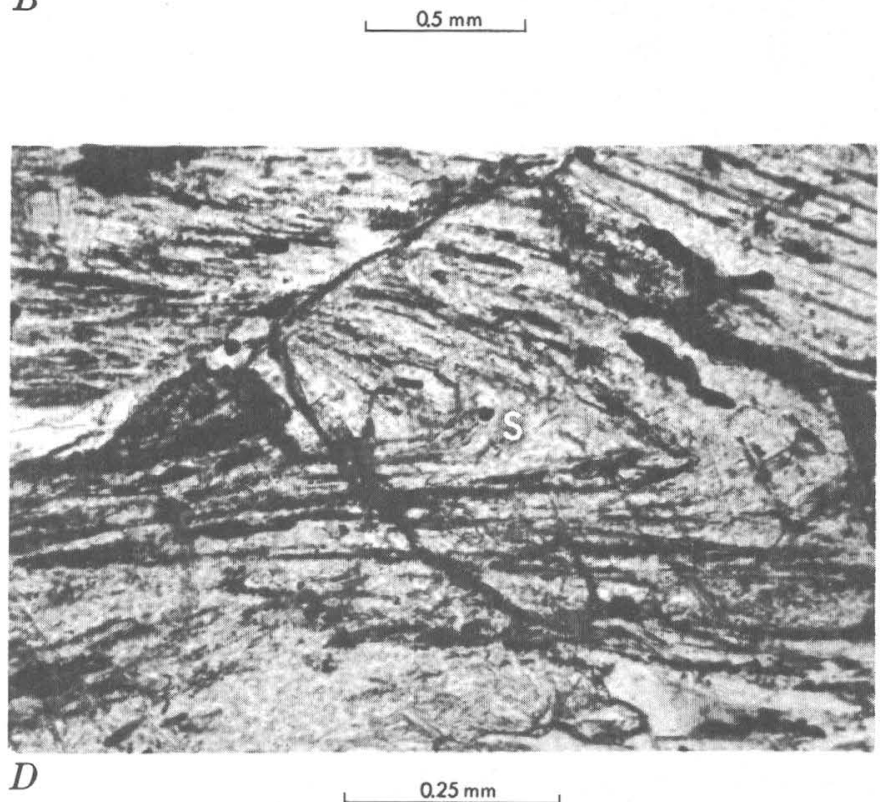

$D$

FIGURE 26.-Photomicrographs showing different age relationships between metamorphisms and deformations. Location of specimens shown on figure 24. $A$, Synkinematic $\left(D_{1}\right)$ growth of garnet $(G)$ in metapelites from the Walloomsac Formation. Sigmoidally arranged inclusions are graphite and quartz. Nearly crossed polarizers. $B$, D: kink bands refracted around $\mathrm{M}_{1}$ porphyroblast of garnet $(\mathrm{G})$. $\mathrm{D}_{1}$ foliation indicated in the garnet by graphite inclusions, which are continuous with muscovite (kinked) grains outside the garnet. Same location as $A$. Plane-polarized light. $C$, Synkinematic (D $)_{2}$ growth of garnet $\left(\mathrm{G}_{1}\right)$ in metapelite from the Hoosac Formation. Inclusions are quartz. Postkinematic growth of garnet $\left(\mathrm{G}_{2}\right)$ is inclusion free. Nearly crossed polarizers. D, Postkinematic ( $\mathrm{D}_{2}$ ) growth of staurolite (S) which incorporated a $\mathrm{D}_{2}$ isoclinal fold outlined by graphite inclusions. From the Hoosac Formation. Plane-polarized light. 
Eastward, across the Hoosac nappe (fig. 24), the $\mathrm{D}_{1}$ foliation is composed of muscovite, chlorite, chloritoid, biotite, and recrystallized quartz. Southward along the Cambrian-Precambrian contact, the $\mathrm{D}_{1}$ foliation is formed by the same minerals. Locally quartz-rich layers within the Hoosac schist have been subject to cataclasis $\left(\mathrm{D}_{1}\right)$ and mosaics of interlocking quartz grains and albite porphyroblasts are commonly broken across grain boundaries and strung out in trains parallel to $\mathrm{D}_{1}$ foliation.

These observations suggest a regional metamorphic event that spanned $D_{1}$ time. Prograde metamorphism reached biotite grade prior to $D_{1}$, reached garnet grade during $D_{1}$ in the northwest corner of figure 24, and reached somewhat higher garnet grade after $D_{1}$ in area 1 . The peak of metamorphism was reached in the northwest and the intensity decreased eastward and southeastward.

\section{METAMORPHISM $2\left(\mathrm{M}_{2}\right)$}

The next metamorphic event is correlated in time with $\mathrm{D}_{2}$ and is designated $\mathbf{M}_{2}$. In the northwest part of figure 24, in pelitic rocks, $M_{2}$ is evidenced most commoniy by retrograde chlorite (after garnet) and recrystallized muscovite and paragonite which locally appear to be folded by and locally crosscut $\mathrm{D}_{2}$ structures. Rarely, minor garnet growth (primarily static), believed to be $\mathbf{M}_{2}$, appears to postdate $\mathrm{D}_{2}$ kink bands. Most commonly, $\mathrm{D}_{2}$ structures are refracted around $\mathrm{M}_{1}$ porphyroblasts (fig. $26 B$ ), and no new prograde minerals were formed during $\mathrm{M}_{2}$.

Eastward and southeastward, prograde syntectonic $\left(D_{2}\right)$ metamorphism reached garnet grade, as evidenced by garnets which contain sigmoidally arranged trains of inclusions which may be traced into the schistosity associated with $\mathrm{D}_{2}$ (fig. $26 C$ ). The schistosity is locally composed of muscovite, paragonite, chlorite (prograde?), biotite, and ilmenite; some of these minerals may have predated $\mathbf{M}_{2}$ and $\mathrm{D}_{2}$ and were rotated into parallelism with $\mathrm{D}_{2}$ foliation. Others surely developed during the prograde formation of garnet during $\mathbf{M}_{2}$. In the Peru quadrangle and farther south, garnets continued to grow as static overgrowths and as new porphyroblasts after $\mathrm{D}_{2}$. It is not known whether this prograde garnet is part of $\mathrm{M}_{2}$ or part of a later event, $\mathrm{M}_{3}$.

These observations suggest a regional prograde metamorphic event, $M_{2}$, perhaps starting prior to $D_{2}$, reaching garnet grade at the peak of metamorphism during $\mathrm{D}_{2}$ and, locally, possibly slightly later. The locus of maximum intensity was along the eastern side of the Precambrian terrane with generally lower (retrograde) processes dominating to the northwest.

\section{METAMORPHISM $3\left(\mathbf{M}_{3}\right)$}

South of the staurolite, kyanite, and sillimanite isograds (fig. 24), these three minerals crosscut $\mathrm{D}_{2}$ schistosity and therefore postdate $\mathrm{D}_{2}$ (fig. $26 D$ ), but they are deformed by and thus predate $\mathrm{D}_{3}$. Farther east in the Goshen Formation in the same metamorphic zones, however, these minerals clearly postdate $\mathrm{D}_{3}$ structures (see Hatch, 1975). This writer has observed alined kyanite porphyroblasts in the Goshen Formation (Devonian and Silurian) in the Chester quadrangle east of the Becket quadrangle (fig. 24), and, although it is not known for sure what generation is responsible for this alignment (either $D_{2}$ or $D_{3}$ ), it is most probably $D_{3}$.

This disparity in the time relationships between $\mathrm{D}_{3}$ and the peak of metamorphism as a function of location suggests two possible explanations: (1) $\mathrm{D}_{3}$ was time transgressive to the west and (2) $\mathbf{M}_{3}$ was time transgressive to the east.

A third, seemingly less likely, explanation calls for one long metamorphic event $\left(\mathbf{M}_{2}\right)$ which spanned both $\mathrm{D}_{2}$ and $\mathrm{D}_{3}$ with the locus of most intense metamorphism migrating eastward with time.

Along the east side of the Precambrian terrane within the pelites, $\mathbf{M}_{2}$ porphyroblasts, especially garnet, are locally retrograded to chlorite. Staurolite in rocks to the southeast is not retrograded appreciably. These observations suggest that the retrograde chlorite after garnet may have been formed during $\mathbf{M}_{3}$. Very locally in the southeastern part of figure 24, chlorite has been observed crosscutting $\mathrm{D}_{3}$ structures, suggesting a minor phase of post- $\mathrm{D}_{3}$ retrograde metamorphism. Whether or not this retrograding is part of $\mathrm{M}_{3}$ is speculative because farther east in the Silurian and Devonian rocks this writer has observed large areas of major retrograde metamorphism of $\mathbf{M}_{3}$ porphyroblasts which in turn are clearly post- $\mathrm{D}_{3}$ (Hatch, 1975).

\section{PALEOZOIC METAMORPHISM(S) OF PRECAMBRIAN ROCKS}

North of the study area, in southern Vermont (Skehan, 1961), and at the north end of the Berkshire massif where the Paleozoic rocks are in the garnet zone or lower, there is a metamorphic discontinuity between the Paleozoic and Precambrian rocks. Mineralogy and textures of the Precambrian rocks suggest that these rocks were metamorphosed to at least kyanite and probably sillimanite grade before the Paleozoic thermal metamorphisms.

The superposition of lower grade Paleozoic 
metamorphisms on higher grade Precambrian rocks caused locally intense retrograde metamorphism. Most retrograde minerals do not show any preferred orientation and thus their development cannot be related to a specific deformational event $\left(D_{1}, D_{2}\right.$, or $\left.D_{3}\right)$ or the associated metamorphic events $\left(M_{1}, M_{2}\right.$, and $\mathbf{M}_{3}$ ). However, in some of the Precambrian gneisses in the southeastern part of figure 24, euhedral garnet crystals locally cut $\mathrm{D}_{1}$ foliation; this is the only prograde mineral in these rocks that is probably Paleozoic in age $\left(\mathrm{M}_{2}\right.$ or $\left.\mathrm{M}_{3}\right)$. More commonly, where cataclasis $\left(\mathrm{D}_{1}\right)$ (fig. $27 \mathrm{~A}$ ) of the gneisses has occurred, biotite and rarely muscovite appear to have grown parallel to $\mathrm{D}_{1}$ foliation. Magnetite octahedra commonly crosscut $D_{1}$ foliation (fig. 27B).

In areas within the Precambrian where $D_{1}$ foliation is absent, retrograde metamorphism is evidenced by garnet commonly sheathed by or totally replaced by chlorite, by potassium feldspar being sericitized, by diopside and scapolite being converted partially to tremolite, talc, and sericite, and, locally, even by biotite being altered to chlorite. The intensity of these effects diminishes southward.

These retrograde effects could have resulted from the superposition of any relatively lower grade metamorphism on any $\mathrm{D}_{1}$ mineralogy and texture. Consequently, the precise age of retrograde minerals in Precambrian rocks is not known.

\section{SUMMARY}

The Ordovician and Cambrian rocks at the north end of the Berkshire massif have been sequentially deformed by at least five tectonic events, at least three of which are Paleozoic in age. These three events were accompanied by individual regional thermal metamorphic events.

The first deformation $\left(D_{1}\right)$ (Taconic) resulted in the formation of large recumbent east-over-west folds and related thrust faults which are located along the western front of, within, and along the east margin of the Precambrian terrane. At least two distinct thrust events have been delineated; the earliest produced northwest-trending faults. These were then cut by north-trending faults. The faults within the Precambrian have been openly folded, possibly at the close of $D_{1} \cdot D_{1}$ was accompanied by metamorphism $\left(\mathbf{M}_{1}\right)$ as high as garnet grade west of the present axis of the massif with decreasing intensity to the east. $D_{1}$ deformation is largely responsible for the present distribution of the Ordovician and Cambrian rocks in the area.

During Acadian time, the Ordovician and Cam-
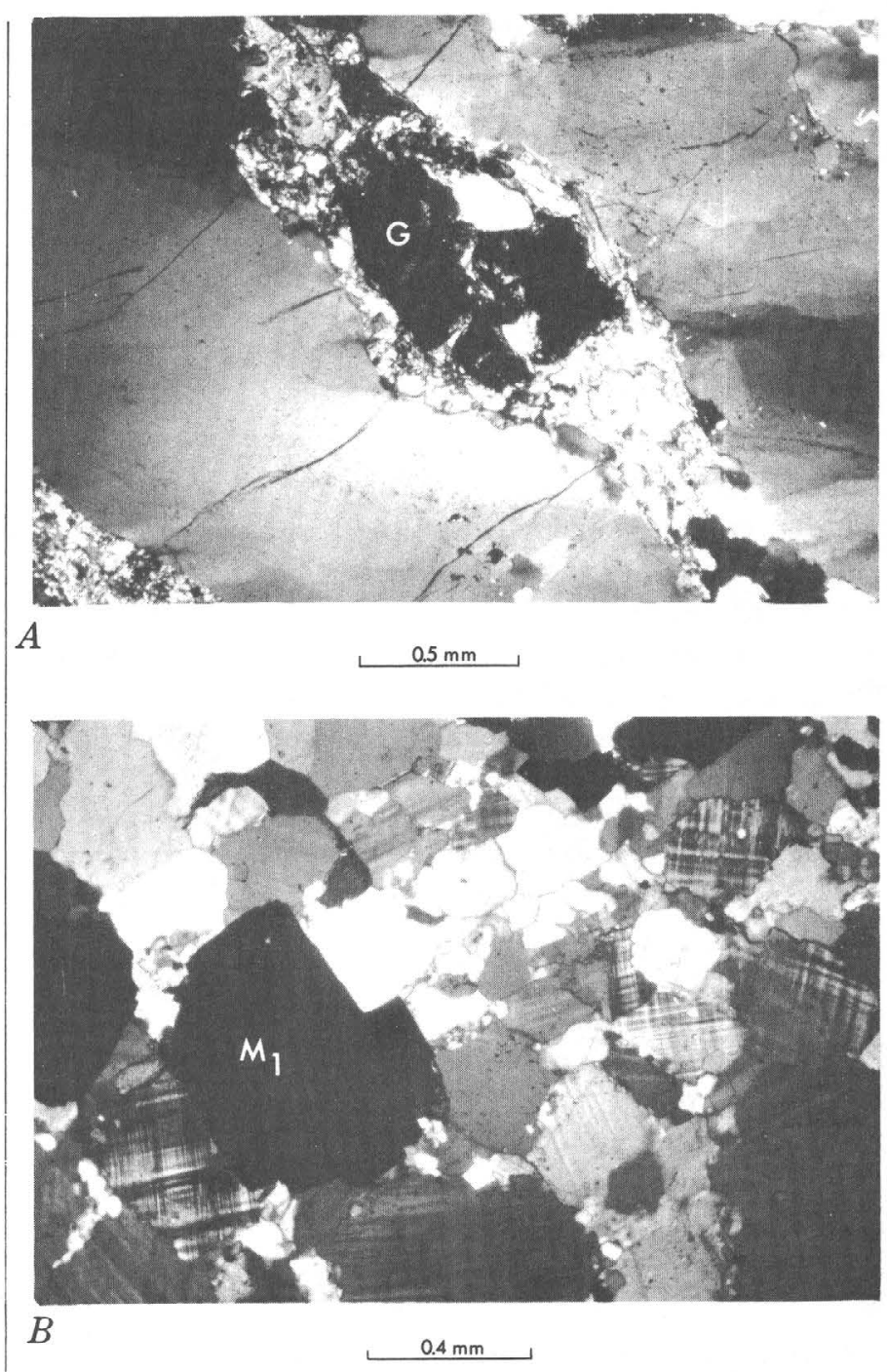

FICURE 27.-Photomicrographs showing the effects of Paleozoic metamorphisms and deformations on Precambrian rocks. ('rossed polarizers. Location of specimens shown on figure 24. $A$, Cataclastically deformed $\left(D_{1}\right)$ garnet $(\mathrm{G})$ with mortared quartz at grain boundaries. From the Precambrian gneiss. $B$, Post- $\mathrm{D}_{1}$ euhedral to subhedral magnetite $\left(\mathbf{M}_{1}\right)$ crosscutting mortared quartz grains (cataclasis- $D_{1}$ ) within the Precambrian gneiss.

br:an rocks were refolded $\left(D_{2}\right)$, with the develop$m \in n t$ of generally north-trending small-scale folds. The intensity of $\mathrm{D}_{2}$ increased eastward and decreased westward, and the dip and plunge of minor folds varies systematically with changes in the orientation of $\mathrm{D}_{1}$ structures. East of the Precambrian massif, folds plunge steeply to the east; north and west of the Precambrian massif, they plunge shallowly to the north. Metamorphism $\left(\mathbf{M}_{2}\right)$ accompanied $\mathrm{D}_{2}$ deformation with the locus of most intense metamorphism (garnet grade) lying to the east of the presently exposed Precambrian. 
Also during Acadian time, $\mathrm{D}_{1}$ and $\mathrm{D}_{2}$ structures were folded by $\mathrm{D}_{3}$ which produced only slight modification of the regional map pattern. A third metamorphic event $\left(M_{3}\right)$ accompanied $D_{3}$ with the peak in metamorphism coming prior to $\mathrm{D}_{3}$ at the east side of the massif. Farther east (Hatch, 1975) $\mathbf{M}_{3}$ postdated $D_{3}$, implying a time transgressive (to the east) metamorphism. The peak of metamorphism reached sillimanite grade.

$\mathrm{D}_{4}$ folds of unknown age and unaccompanied by thermal metamorphism affected the entire area. Folds generally are crinkles or warps. North-trending subhorizontal arching (possibly $\mathrm{D}_{4}$ ) is believed to have steepened $D_{1}$ and $D_{2}$ structures on the east side of the Berkshire massif and gently arched the Hoosac nappe. The intensity of $\mathrm{D}_{4}$ structures diminishes from north to south.

Postmetamorphic north-trending nearly vertical faults, ranging in size from minor fractures within a single outcrop to breccia zones $100 \mathrm{~m}$ (340 ft) wide and at least several kilometres long cut all previous structures. They may be Triassic in age.

\section{ACKNOWLEDGMENTS}

Working with and discussing problems with A. H. Chidester, R. G. Clark, Jr., S. F. Clark, Jr., D. S. Harwood, N. L. Hatch, Jr., P. H. Osberg, N. M. Ratcliffe, and E-an Zen have been extremely helpful. Edward Stoddard, B. H. Penrose, and David Cook served as my field assistants in 1970, 1971, and 1972, respectively, when the thoughts presented here were put in order. L. R. Page, through his roles of supervisor and devil's advocate, has forced me, with constant encouragement, to see things that would otherwise have escaped me.

The report has benefitted significantly from reviews by D. S. Harwood and N. L. Hatch, Jr.

Part of this study was supported by National Science Foundation grant GA-24967.

\section{REFERENCES CITED}

Gates, R. M., Martin, C. W., and Schnabel, R. W., 1973, The Cambrian-Precambrian contact in northwestern Connecticut and west central Massachusetts [abs.]: Geol. Soc. America, Abs. with Programs, v. 5 no. 2, p. 165.

Hatch, N. L., Jr., 1967, Redefinition of the Hawley and Goshen Schists in western Massachusetts: U.S. Geol. Survey Bull. 1254-D, p. D1-D16.

1975, Tectonic, metamorphic, and intrusive history of part of the east side of the Berkshire massif, Massachu- setts, in Tectonic studies of the Berkshire massif, western Massachusetts, Connecticut, and Vermont: U.S. Geol. Survey Prof. Paper 888-D, p. 51-62.

Hatch, N. L., Jr., Osberg, P. H., and Norton, S. A., 1967, Stratigraphy and structures of the east limb of the Berkshire anticlinorium, in New England Intercollegiate Geol. Conf., 59th Ann. Mtg., Oct. 13-15, 1967, Guidebook for field trips in the Connecticut Valley of Massachusetts: Amherst, Mass., p. 7-16.

Hatch, N. L., Jr., Norton, S. A., and Clark, R. G., Jr., 1970, Geologic map of the Chester quadrangle, Hampden and Hampshire Counties, Massachusetts: U.S. Geol. Survey Geol. Quad. Map GQ-858.

Harwood, D. S., 1972, Tectonic events in the southwestern part of the Berkshire anticlinorium, Massachusetts and Connecticut [abs.]: Geol. Soc. America, Abs. with Programs, v. 4, no. 1, p. 19.

Herz, Norman, 1958, Bedrock geology of the Cheshire quadrangle, Massachusetts: U.S. Geol. Survey, Geol. Quad. Map GQ-108.

1961, Bedrock geology of the North Adams quadrangle, Massachusetts-Vermont: U.S. Geol. Survey Geol. Quad. Map, GQ-139.

Norton, S. A., 1967, Geology of the Windsor quadrangle, Massachusetts: U.S. Geol. Survey open-file report, 210 p. - 1971, Possible thrust faults between Lower Cambrian and Precambrian rocks, east edge of the Berkshire highlands, western Massachusetts [abs.]: Geol. Soc. America, Abs. with Programs, v. 3, no. 1, p. 46.

Ratcliffe, N. M., and Harwood, D. S., 1975, Blastomylonites associated with recumbent folds and overthrusts at the western edge of the Berkshire massif, Connecticut and Massachusetts-a preliminary report, in Tectonic studies of the Berkshire massif, western Massachusetts, Connecticut, and Vermont: U.S. Geol. Survey Prof. Paper 888-A, p. 1-19.

Ratcliffe, N. M. and Zartman, R. E., 1971, Precambrian granitic plutonism and deformation in the Berkshire massif of western Massachusetts [abs.]: Geol. Soc. America, Abs. with Programs, v. 3, no. 1, p. 49.

Robinson, Peter, 1967, Introduction to the geology of the Connecticut valley of Massachusetts, in New England Intercollegiate Geol. Cong., 59th Ann. Mtg., Oct. 13-15, 1967, Guidebook for field trips in the Connecticut Valley of Massachusetts: Amherst, Mass., p. 1-6.

Skehan, J. W., 1961, The Green Mountain anticlinorium in the vicinity of Wilmington and Woodford, Vermont: Vermont Geol. Survey Bull. 17, 159 p.

Stanley, R. S., 1968, Bedrock geology of western Connecticut, in New England Intercollegiate Geological Conference 60th Ann. Mtg. Oct. 25-27, Guidebook for field trips in Connecticut: Connecticut Geol. and Nat. History Survey Guidebook no. 2, p. DO-1-DO-5.

1975, Time and space relationships of structures associated with the domes of southwestern Massachusetts and western Connecticut, in Tectonic studies of the Berkshire massif, western Massachusetts, Connecticut, and Vermont: U.S. Geol. Survey Prof. Paper 888-F, p. 69-96. 



\section{Tectonic and Metamorphic Chronology of the Devonian and Silurian Rocks in the Guilford Dome Area, Southeastern Vermont}

BY J. CHRISTOPHER HEPBURN

TECTONIC STUDIES OF THE BERKSHIRE MASSIF, WESTERN MASSACHUSETTS, CONNEGTICUT, AND VERMONT

GEOLOGICAL SURVEY PROFESIONAL PAPER 888-C

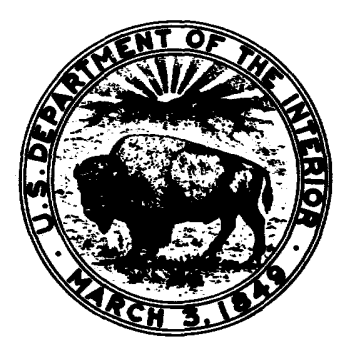





\section{CONTENTS}

\begin{tabular}{|c|c|c|c|}
\hline \multirow[b]{2}{*}{ Abstract } & Page & & Page \\
\hline & & Structure-Continued & \\
\hline Introduction & 33 & Black Mountain Granite & \\
\hline Previous work -- & 33 & Discussion & 43 \\
\hline Stratigraphy & 35 & Metamorphism -. & \\
\hline Structure & 35 & Relation of metamorphism to deformation & $\begin{array}{l}45 \\
46\end{array}$ \\
\hline Major deformation & 35 & $\begin{array}{l}\text { Age or metamorpnism and derormation } \\
\text { Summary }\end{array}$ & 47 \\
\hline Minor folds & 39 & Acknowledgments & 47 \\
\hline Dummerston fault & 43 & References cited & 48 \\
\hline
\end{tabular}

\section{ILLUSTRATIONS}

FIGURE 28. Map showing regional geologic features and location of the Guilford dome area

29. Geologic map and cross sections of the Guilford dome area

30. Columnar sections of the Guilford dome area

31. Lower hemisphere equal-area stereonet plot of minor fold hinges, Prospect Hill fold

32. Map of the principal structural features, Guilford dome area

33. Lower hemisphere equal-area stereonet plot of minor fold hinges, Fall Brook anticline

34. Photograph of $F_{1}$ folds in Standing Pond Volcanics, Dummerston, Vt.

35. Photograph of typical $F_{2}$ minor fold in Standing Pond Volcanics, Prospect Hill recumbent fold .....--

36. Sketch of $F_{2}$ fold in an impure marble bed in the Waits River Formation

37. Lower hemisphere stereonet plot of the poles to the axial surfaces of minor $F_{2}$ folds, north end of the Guilford dome

38. Photograph of slip cleavage in the Northfield Formation

39. Photomicrograph of crinkles and slip cleavage in mica schist of the Northfield Formation

40. Photomicrograph of a garnet from the Gile Mountain Formation, Guilford, Vt.

41. Plot of the variation in weight percent $\mathrm{FeO}$ and $\mathrm{MnO}$ across zoned garnet

42. Schematic cross sections showing the evolution of structural features in the Guilford dome area

\section{TABLE}





\author{
TECTONIC STUDIES OF THE BERKSHIRE MASSIF, WESTERN MASSACHUSETTS, \\ CONNECTICUT, AND VERMONT
}

\title{
TECTONIC AND METAMORPHIC CHRONOLOGY OF THE DEVONIAN AND SILURIAN ROCKS IN THE GUILFORD DOME AREA, SOUTHEASTERN VERMONT
}

\author{
By J. Christopher Hepburn ${ }^{1}$
}

\begin{abstract}
The deformational history of the Guilford dome area includes two major and at least five minor stages of folding. The Prospect Hill recumbent fold formed during the first major deformational stage and was deformed by the subsequent rising of the Guilford dome during the second major stage. The doming arched the axial surface of the earlier fold so that the hinge of the recumbent fold now plunges northeast and southwest, away from the dome.

Tight to isoclinal folds formed during the first two stages of minor folding. The earliest minor folds $\left(F_{1}\right)$ predate the major recumbent folding and have a well developed schistosity parallel to their axial surfaces. This schistosity and the $F_{1}$ folds have been refolded by the Prospect Hill recumbent fold $\left(F_{2}\right)$ and its congruous minor folds. The $F_{2}$ folds have a slip cleavage parallel to their axial surfaces in the more competent rocks; this cleavage becomes a schistosity in the pelitic rocks. The $F_{3}$ and $F_{4}$ folds are open minor folds. It is believed the $F_{3}$ folds formed contemporaneously with the rise of the Guilford dome. These folds are more open than the preceding minor folds and have a prominent slip cleavage parallel to their axial surfaces. The youngest folds are large open folds $\left(F_{5}\right)$ and kink bands in the eastern part of the area that represent one or more stages of deformation.

The peak of metamorphism (staurolite-kyanite zone) was reached late in the deformational sequence, following the rise of the Guilford dome. $\mathrm{Rb}-\mathrm{Sr}$ dates on coarse muscovites from the Black Mountain Granite, a late synorogenic intrusion, indicate that the deformation and metamorphism are Acadian.
\end{abstract}

\section{INTRODUCTION}

The Guilford dome is in a belt of domes that extends southward from east-central Vermont to Connecticut. These domes are analogous to, but more widely spaced than, the belt of domes forming the Bronson Hill anticlinorium to the east (Billings, 1956; Thompson and others, 1968). In Vermont, this western belt of domes occurs along or just west of the axial region of the Connecticut Valley-Gaspé

\footnotetext{
1 Boston College, Chestnut Hill, Mass.
}

synclinorium (Doll and others, 1961), which contains Devonian and Silurian metasedimentary and metavolcanic rocks between older rocks exposed in the Bronson Hill anticlinorium to the east and in the Green Mountain anticlinorium to the west (fig. 28). Domes in this belt have exposed cores of either Precambrian rocks, as in the Chester, Athens, Sadawaga, and Ray Pond domes, or Paleozoic metamorphic rocks. The Waits River Formation (Devonian and Silurian) forms the exposed core of the Guilford dome. Large recumbent folds are present in the strata mantling these domes (Doll and others, 1961; Rosenfeld, 1968). Some of these recumbent folds are outlined in the outcrop pattern of the Standing Pond Volcanics (fig. 28), as is the case in the Guilford dome.

Metamorphic highs are associated with the Guilford dome and many of the other domes in this belt (Thompson and Norton, 1968; Doll and others, 1961). Rocks exposed in the center of the Guilford dome are in the staurolite-kyanite zone of regional metamorphism (fig. 29).

\section{PREVIOUS WORK}

Thompson (1950), Billings and others (1952) and Rosenfeld (1954) began the detailed geologic mapping of southeastern Vermont and recognized the major deformational stages around the Chester and Athens domes. White and Jahns (1950) found a similar deformational sequence in east-central Vermont. Moore (1949) mapped the eastern third of the Brattleboro 15-minute quadrangle in his study of the Keene-Brattleboro area. Trask (1964) mapped the Vernon-Chesterfield area to the east of the present study area and reinterpreted some features in the Brattleboro quadrangle mapped by 


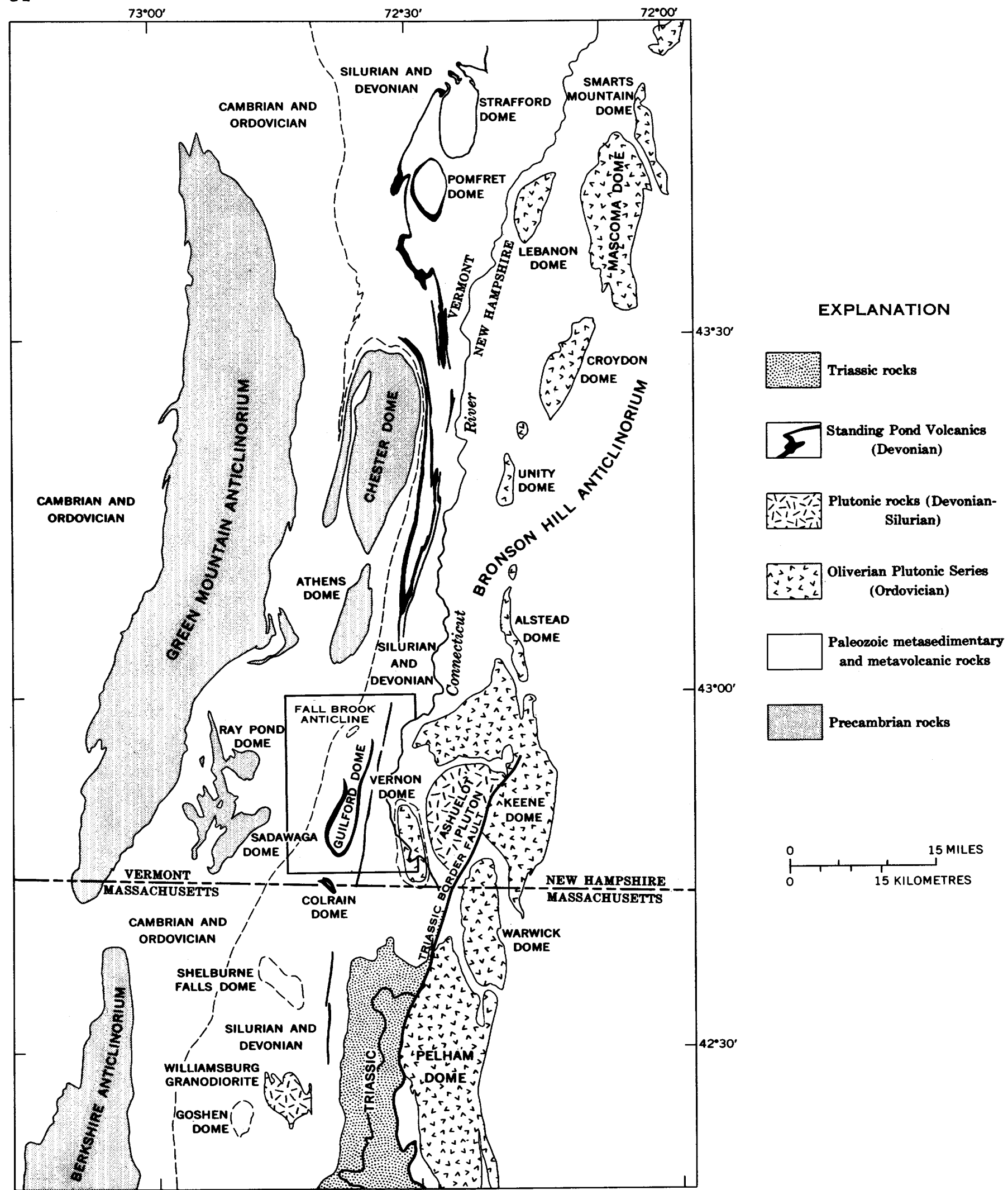

FigUre 28.-Map showing the regional geologic features and the location of the Guilford dome area. The area outlined is shown in figure 29. The dashed line is the contact between the Ordovician and Cambrian rocks in the west and the Devonian and Silurian rocks to the east. This designation applies only to Vermont and Massachusetts west of the Connecticut River. East of the river, the Paleozoic metasedimentary rocks are undifferentiated. Modified from Doll and others (1961), Thompson and others (1968), and Billings (1956). 
Moore. Skehan (1961) mapped the WilmingtonWoodford area to the west of the Brattleboro quadrangle; Segerstrom (1956) and Balk (1956) mapped the adjoining areas to the south. The geologic map of Vermont (Doll and others, 1961) summarizes the results of the mapping up to 1961. Rosenfeld (1960, $1965,1968)$ has contributed to the understanding of the structural history of southeastern Vermont through his detailed studies of rotated garnets. An excellent regional summary of the geology of part of the Bronson Hill anticlinorium, including the area directly to the east of the present study area, has been presented by Thompson and others (1968).

\section{STRATIGRAPHY 2}

The stratigraphy of the Brattleboro quadrangle is summarized in figure 30 ; more complete descriptions of the units are given by Hepburn (1972). Recent discussions of the ages assigned to these rocks are given by Chang and others (1965), Cady (1969) and Billings (1956).

The Vermont and New Hampshire sequence designations (Billings, 1956) are used to differentiate units that are widely mapped within each of the respective states. The correlation of the Devonian and Silurian parts of these two sequences is still in question (Billings, 1956; Cady, 1960), although it is likely the Littleton Formation is equivalent to at least part of the Northfield through the Gile Mountain sequence.

The facing direction of the Waits River, Standing Pond, and Gile Mountain Formations in the Vermont sequence is also a problem (Chang and others, 1965 ; Cady, 1960; and Hall, 1959). No new definitive evidence of the facing of these units has been found in the Brattleboro quadrangle by the author. The sequence of these formations as shown in figure 30 is favored by the author and many others (Doll and others, 1961; Chang and others, 1965), but a possible inversion of this order cannot be ruled out.

\section{STRUCTURE}

At least five stages of minor folding $\left(F_{1}-F_{5}\right)$ affected the Devonian and Silurian rocks in the Guilford dome area. These minor folds were formed prior to, during, and subsequent to the development of the two major structural features, the Prospect Hill recumbent fold and the Guilford dome. The recumbent fold formed during the earlier of the two major stages of deformation and was subsequently deformed by the rise of the dome.

\footnotetext{
2 Because the information in this chapter is from many sources, the formal nomenclature and geologic ages of formations used herein do not necessarily reflect the current lisage of the U.S. Geological Survey.
}

\section{MAJOR DEFORMATION}

Prospect Hill recumbent fold.-The Prospect Hill fold is well exposed as a doubly closed loop of the Standing Pond Volcanics extending around the southern end of the Guilford dome (fig. 29). The Gile Mountain Formation is in the core of this fold, which is named for Prospect Hill, Dummerston, where excellent exposures of the hinge in the Standing Pond Volcanics occur at the northeastern end of the loop. The outcrop pattern shown by the Standing Pond Volcanics, the Gile Mountain Formation, and the quartzitic member of the Waits River Formation is an excellent example of a refolded fold with a Ramsay Type II pattern (Ramsay, $1962,1967)$. Prior to the doming, the recumbent fold had a subhorizontal axial surface and a hinge striking approximately N. $45^{\circ} \mathrm{E}$. The doming refolded the recumbent fold, so that it now plunges moderately northeast (fig. 31) and southwest, away from the north-south axis of the dome (fig. 32). The exact amplitude of the Prospect Hill fold is impossible to determine, but it is on the order of several miles in the southern part of the Guilford dome.

An early, tight, steeply east-dipping synform must lie directly east of the Guilford dome, between the Standing Pond Volcanics on the east side of the Guilford dome and the easternmost band of the Standing Pond Volcanics (just west of the Brattleboro syncline) (figs. 29 and 32). It is believed that this synform is the overturned upper, or anticlinal, part of the Prospect Hill fold.

Also correlated with the anticlinal part of the Prospect Hill fold are the Fall Brook anticline and the tongue of Northfield Formation extending around the north end of the Guilford dome (figs. 29 and 32). Ordovician rocks of the Barnard Volcanic and Cram Hill Members of the Missisquoi Formation are exposed in the core of the Fall Brook anticline on the northwest flank of the Guilford dome. The anticline is tight, nearly isoclinal, doubly plunging, and overturned; both limbs dip northwest, the inverted one more steeply $\left(60^{\circ}-85^{\circ}\right)$ than the western one $\left(40^{\circ}-60^{\circ}\right)$. The axial surface dips moderately northwest and is gently curved, striking northeast in the north and north-northeast in the south. The anticline plunges gently to the northeast and southwest (fig. 33).

Guilford dome and Brattleboro syncline.-The Guilford dome and the Brattleboro syncline are prominent structural features that formed during the second major deformational stage. The Guilford dome is a large, elliptical, doubly plunging anti- 


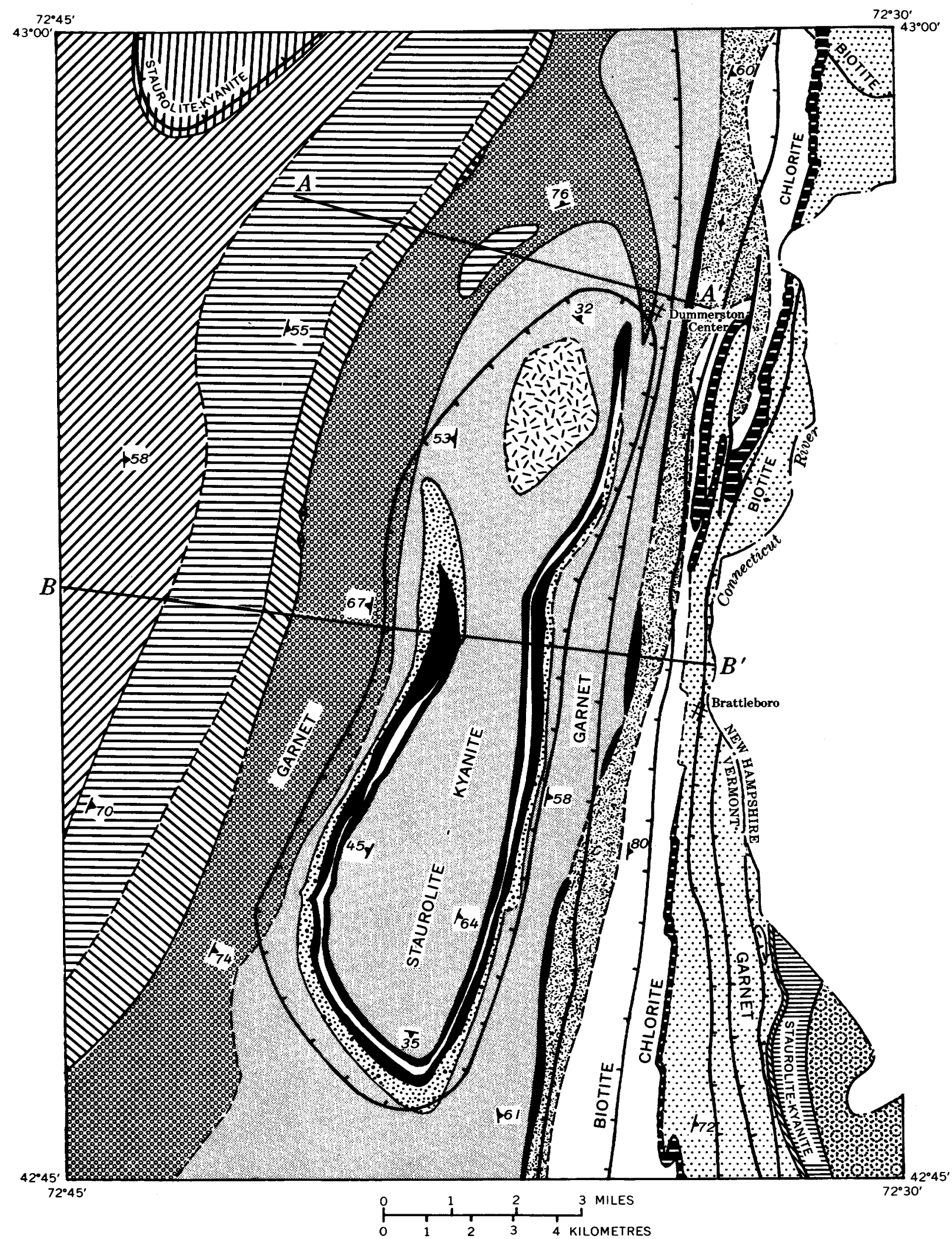

FigURE 29.-Geologic map and cross sections of the Guilford dome area, Brattleboro 15-minute quadrangle, Vermont. Map modified from Hepburn (1972); geology of the easternmost part of the region modified from Trask (1964). 

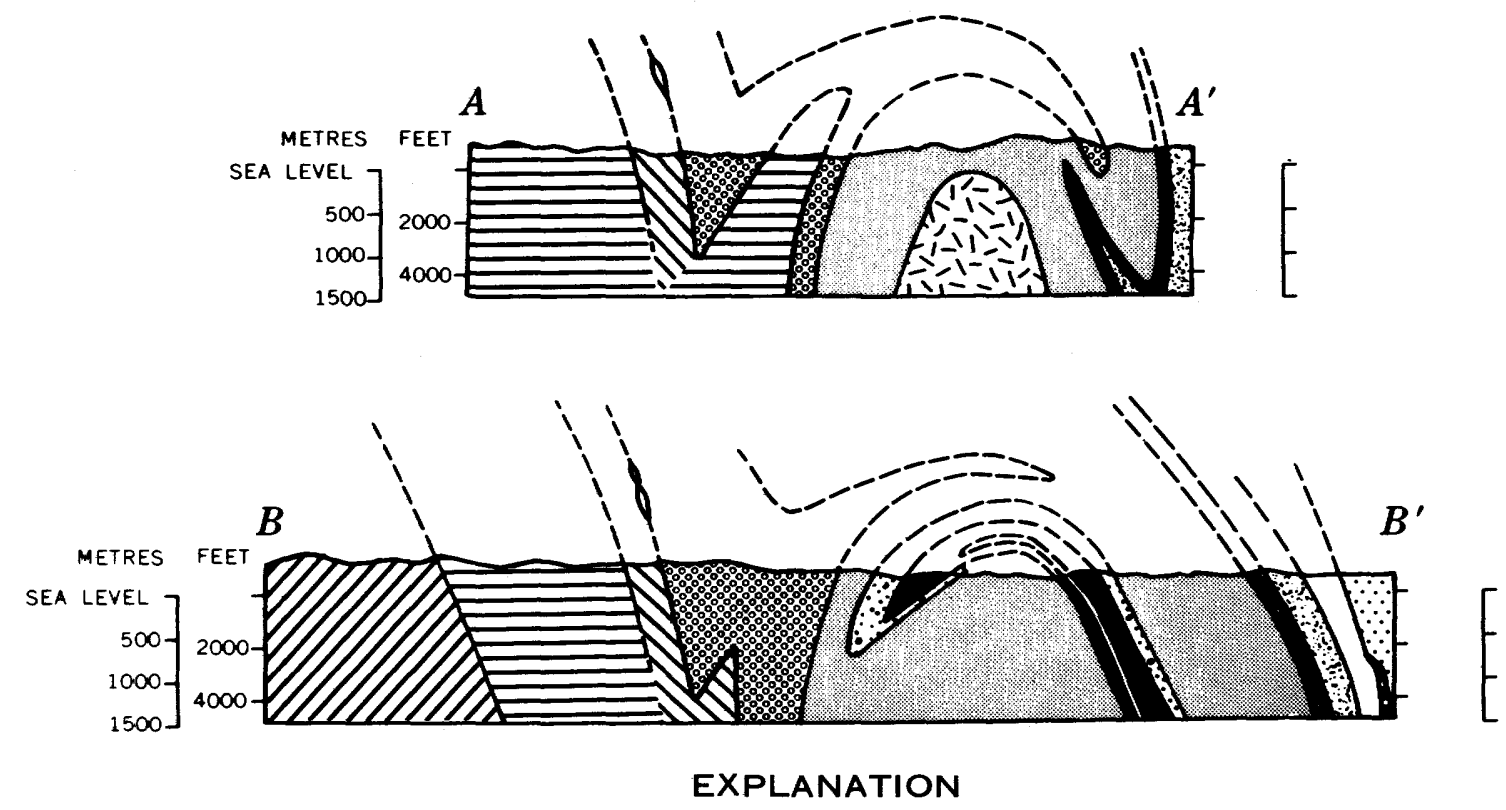

Vermont sequence

Gile Mountain Formation

Gile Mountain Formation, marble member

Standing Pond Voleanics

Waits River Formation, quartzitic member

Waits River Formation

Northfield Formation

Shaw Mountain Formation

Missisquoi Formation

Cram Hill Member

Barnard Volcanic Member

Moretown Member

Cambrian, undifferentiated

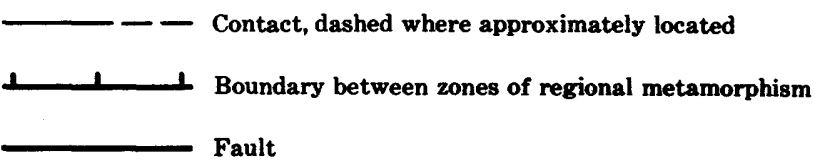

New Hampshire sequence

Plutonic rocks

Putney Volcanic

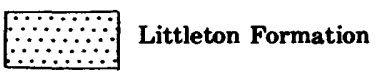

Clough Quartzite

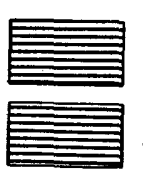

Partridge Formation

Ammonoosue Voleanies 


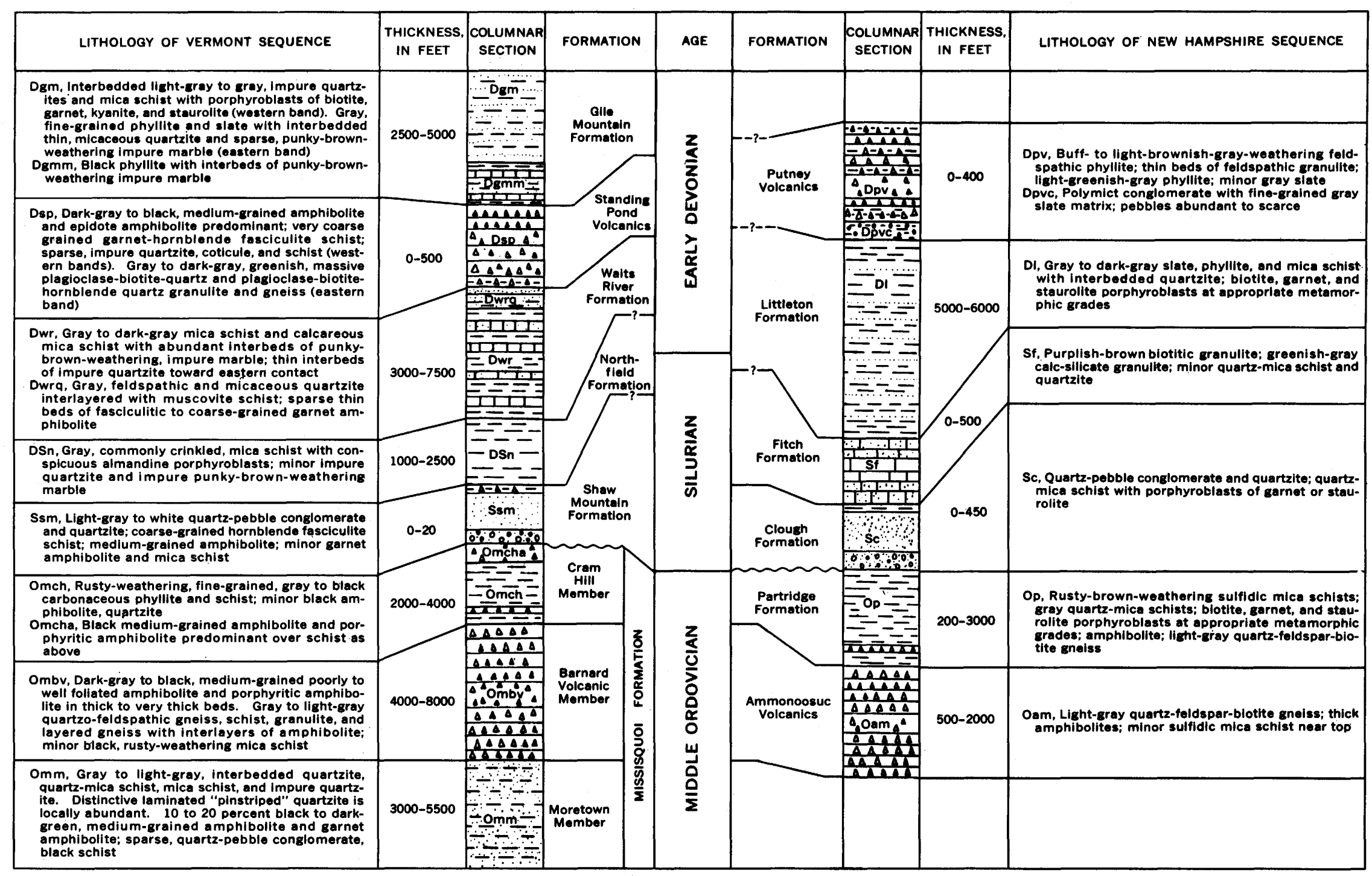

FIGURE 30.-Columnar sections of the Guilford dome area, Brattleboro quadrangle, Vermont and New Hampshire. 


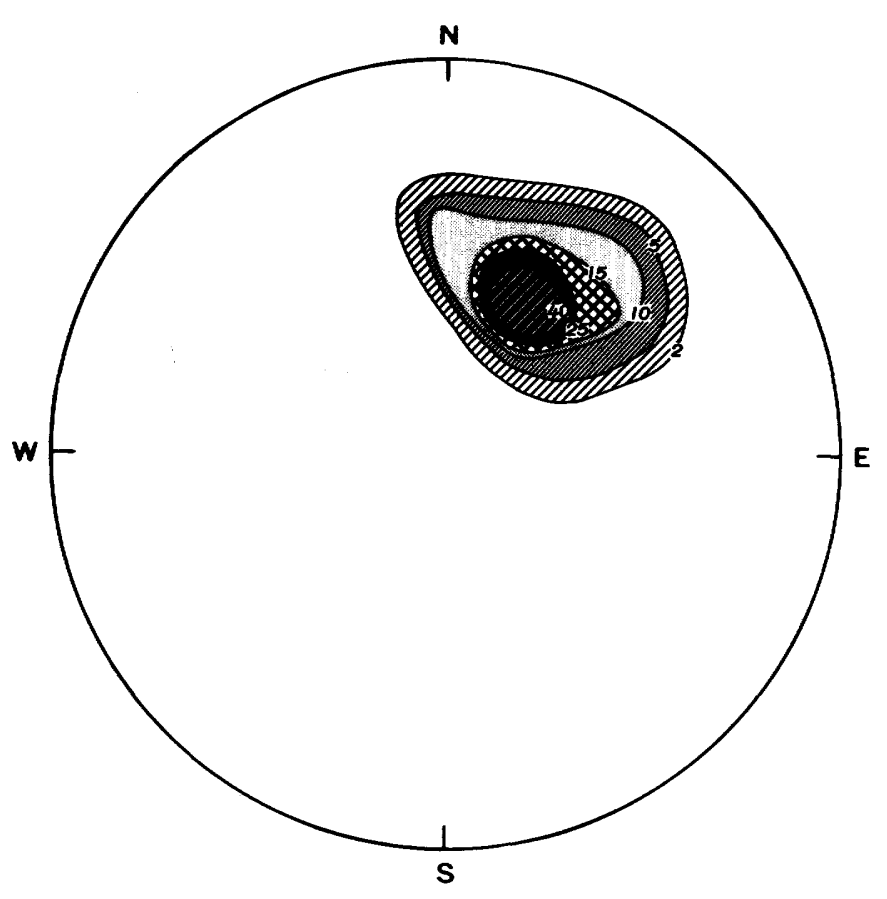

Figure 31.-Lower hemisphere equal-area stereonet plot of minor fold hinges from the hinge area of the Prospect Hill fold at the northeastern end of the Standing Pond loop, Dummerston, Vermont. Fifty fold hinges; contours labeled in percent.

cline having the Waits River Formation exposed in its central part (fig. 32). The Standing Pond Volcanics and the Gile Mountain Formation in the Prospect Hill fold form a doubly closed loop that outlines the flanks of the dome. As measured from this loop, the dome is about $19.2 \mathrm{~km}$ (12 miles) long and $3.2-4.8 \mathrm{~km}$ (2-3 miles) wide. The Black Mountain Granite has intruded the axial region of the dome in its northern part. The hinge of the dome trends slightly east of north and plunges moderately north and south at the ends of the dome. The axial surface of the dome dips very steeply west. A small depression in the axis forms a saddle near the central part of the dome and is reflected on the geological map as a constriction in the mantling rocks. The dome is not symmetrical; the axial trace is closer to the eastern side of the dome and the foliation dips steeply a short distance east of the axial trace, whereas dips are more gentle to the west.

The Brattleboro syncline (Moore, 1949; Trask, 1964; Doll and others, 1961) is the local name for the eastern part of the Connecticut Valley-Gaspé synclinorium between the Guilford dome and the Vernon and Keene domes of the Bronson Hill anticlinorium. The Gile Mountain, Putney, and Littleton Formations occur at relatively low metamorphic grade within this syncline, which developed during the second major stage of the deformation. The Brattleboro syncline strikes approximately N. $10^{\circ}$ E., and both limbs and the axial surface are vertical or steeply dipping to the east. The axis is essentially horizontal. The exact pasition of the trace of the synclinal axial surface depends to some extent on the interpretation of the stratigraphic order of the formations involved; in figure 32 this axial surface has been assumed to lie within the Gile Mountain Formation.

\section{MINOR FOLDS}

The following sequence of deformation has been determined from the interrelations of the various minor structural features (refolded folds, schistosity, cleavage, and so forth). No more than two minor-folding stages were observed in any one outcrop, and the evidence for all of the stages is not preserved in any one part of the Guilford dome area. Deceptively simple minor structural patterns were observed in many localities where one of the deformational stages had been particularly intense. Thus, while the following sequence fits most of the known facts, it is only a hypothesis to be examined in the light of continued work and new facts.

$F_{1}$.-A well-developed schistosity $\left(\mathrm{S}_{1}\right)$ approximately parallels bedding throughout the area. This schistosity is folded by minor folds congruous with the Prospect Hill fold and therefore predates the recumbent folding. A few cases in which $S_{1}$ cuts bedding or layering have been observed in the hinges of small isoclinal folds. Figure 34 shows an $F_{1}$ fold from layered amphibolites in the Standing Pond Volcanics. The principal schistosity is parallel to the axial surfaces of the $F_{1}$ folds. Note that the $F_{1}$ fold and this schistosity have been refolded by an $F_{2}$ minor fold.

No large-scale structural features except the prominent schistosity can be correlated with the $F_{1}$ minor folds.

$F_{2}$.-The $F_{2}$ minor folds formed contemporaneously with the major recumbent folds. These minor folds are isoclinal to moderately open, depending upon the type of rock involved. Amphibolites in the Standing Pond Volcanics and quartz-rich rocks in the Gile Mountain and Waits River Formations are folded more openly than the schists and impure marbles in these same formations. Figure 35 shows a typical $F_{2}$ fold from an amphibolite in the Standing Pond Volcanics, and figure 36 is a sketch of an $F_{2}$ fold from an impure marble bed in the Waits River Formation. The hinge areas of the $F_{2}$ minor folds in the more competent layers characteristically have a weak slip cleavage $\left(S_{2}\right)$ parallel to their axial 


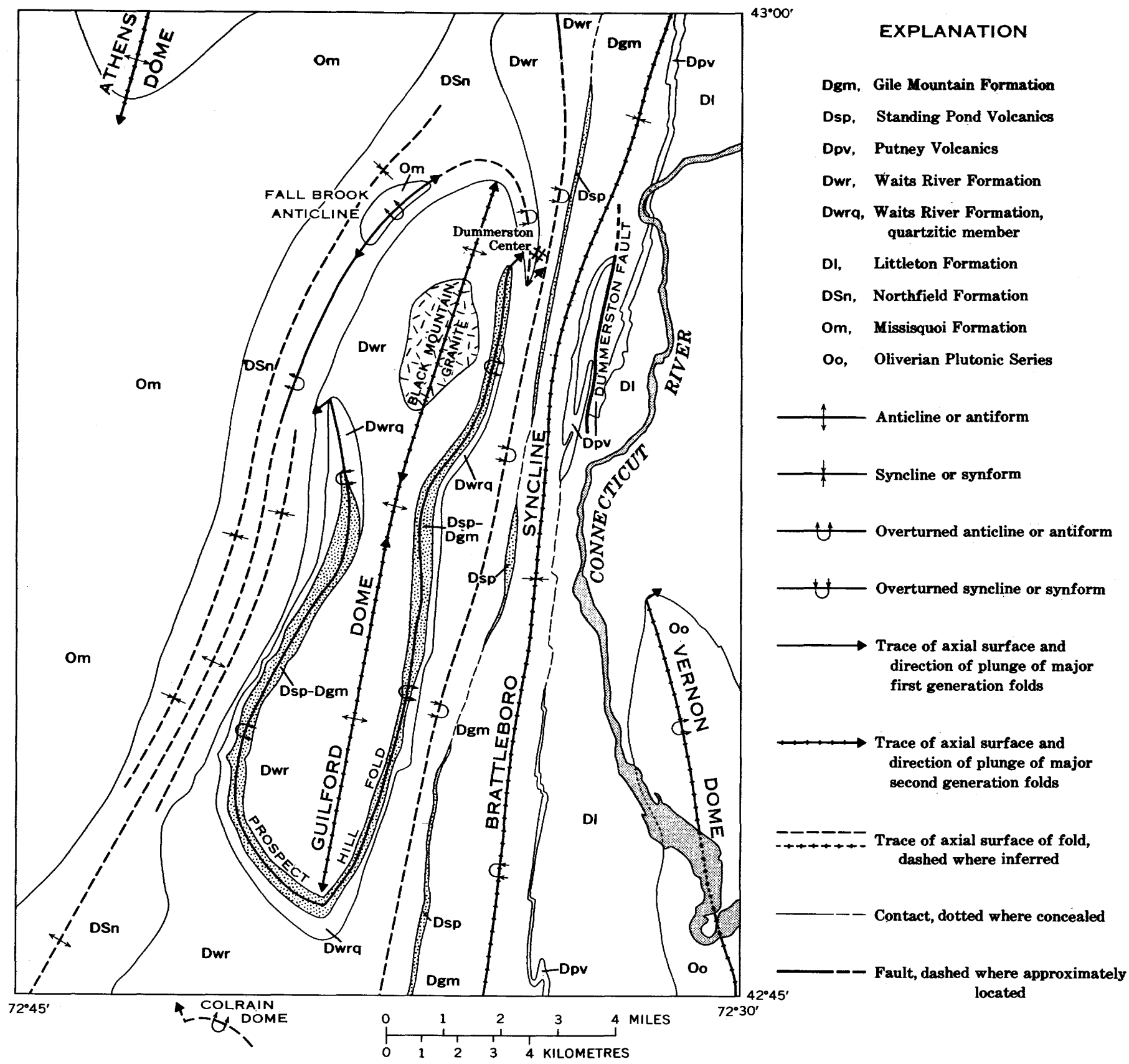

FIGURE 32.-Map of the principal structural features, Guilford dome area, Brattleboro quadrangle, Vermont. Modified from Hepburn (1972). Formation designations simplified from figure 29.

surfaces. $\mathrm{S}_{2}$ becomes a well developed schistosity in the less competent rocks.

The abundance of $\mathrm{F}_{2}$ minor folds increases greatly in the hinge areas of the Prospect Hill fold. Here $F_{2}$ folds show the classic reversal in shearing direction across the axial surface of the larger fold. For example, in the hinge area on Prospect Hill at the northeastern end of the loop, the pattern of minor folds changes from east to west when viewed to the northeast down the axis of the major fold, from $S$ (left-handed) to $M$ to $Z$ (right-handed).

A plot of poles to the axial planes of the $F_{2}$ minor folds which deform the recumbent fold in the northern part of the Guilford dome shows a fairly welldefined great circle distribution about the axis of the later doming (fig. 37).

The $F_{2}$ minor folds associated with the synform east of the Prospect Hill recumbent fold plunge at 


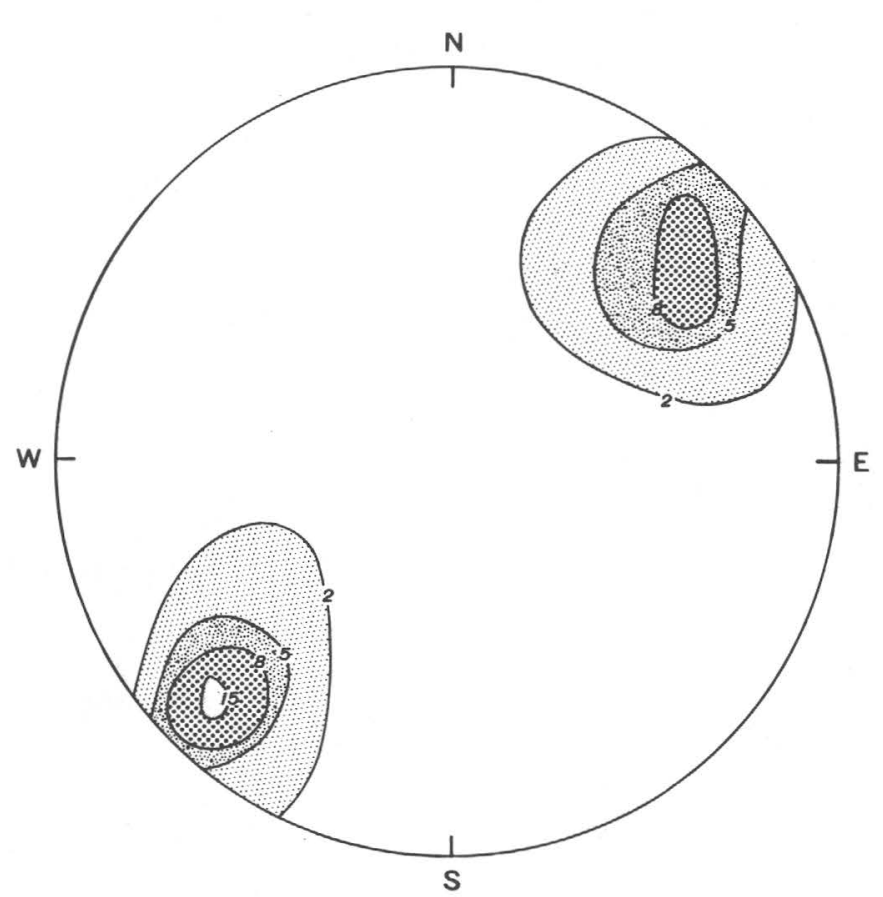

Figure 33.-Lower hemisphere equal-area stereonet plot of minor fold hinges in the Fall Brook anticline. Northeastplunging folds are from exposures near the northeastern end of the fold; southwest-plunging folds are from exposures near the southwestern end of the fold. Eighty-six fold hinges; contours labeled in percent.

moderate angles. The axial surfaces of these folds dip $50^{\circ}-75^{\circ}$ E., parallel to the regional schistosity.

Isoclinal minor folds, tentatively assigned to the $\mathrm{F}_{2}$ stage, occur in the Northfield Formation west of the Guilford dome. They are observed on a scale of several centimetres to as much as $30 \mathrm{~m}$ in places where a few thin quartz-rich beds occur in the otherwise uniform schists of the Northfield. The lack of well-defined bedding throughout the formation hinders the interpretation of the large-scale fold patterns.

Eight determinations of topping direction were made from graded bedding in outcrops of the Northfield Formation, not visibly isoclinally folded. Six of the determinations indicated stratigraphic tops are to the northwest; two indicated tops to the southeast. The Northfield Formation rests unconformably on the Missisquoi Formation to the west, indicating that tops are to the east at the base of the Northfield. Thus, the presence of large isoclinal folds in the Northfield is indicated, as shown schematically in figure 32.

The observed folds in the Northfield are tightly isoclinal, have steeply dipping axial surfaces, and plunge at shallow angles to the northeast or southwest. A well-developed schistosity parallels the axial

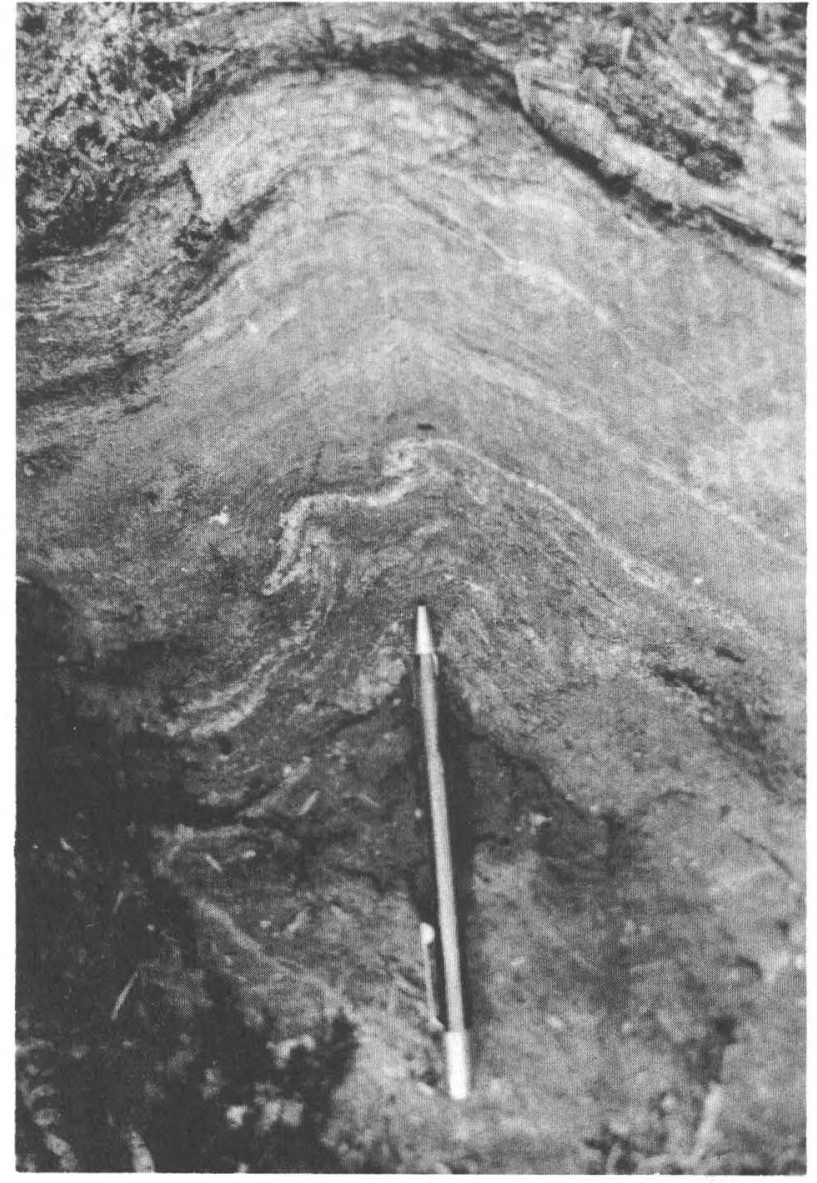

FIGURE 34.- $\mathrm{F}_{1}$ folds in compositional layering in the layered amphibolites of the Standing Pond Volcanics, Dummerston, Vermont. Schistosity $\left(S_{1}\right)$ is parallel to the axial surface of the $F_{1}$ folds. Note refolding by the more open $\mathrm{F}_{2}$ fold, which has an axial trace subparallel to the pencil. The pencil is approximately $12 \mathrm{~cm}$ long.

surfaces of the folds and forms the principal schistosity in the area. The schistosity generally parallels bedding except in the hinges of the folds. In a few cases in particularly quartz-rich beds, it appears that an earlier, now deformed, schistosity parallel to bedding may also be present. These folds have been assigned to the $\mathrm{F}_{2}$ stage of folding largely on the basis of their similarity with the Fall Brook anticline and their northeasterly plunge at the north end of the Guilford dome. The present attitude of the folds, particularly the steeply dipping axial surfaces, is attributed to the later refolding.

$F_{s}$.-Open minor folds with a well-developed slip cleavage (Billings, 1954, p. 339) parallel to their axial surfaces (fig. 38) are assigned to the third stage of minor folding. These folds are particularly well developed west and south of the Guilford dome. They generally plunge moderately northeast and have axial surfaces that usually strike northeast and 


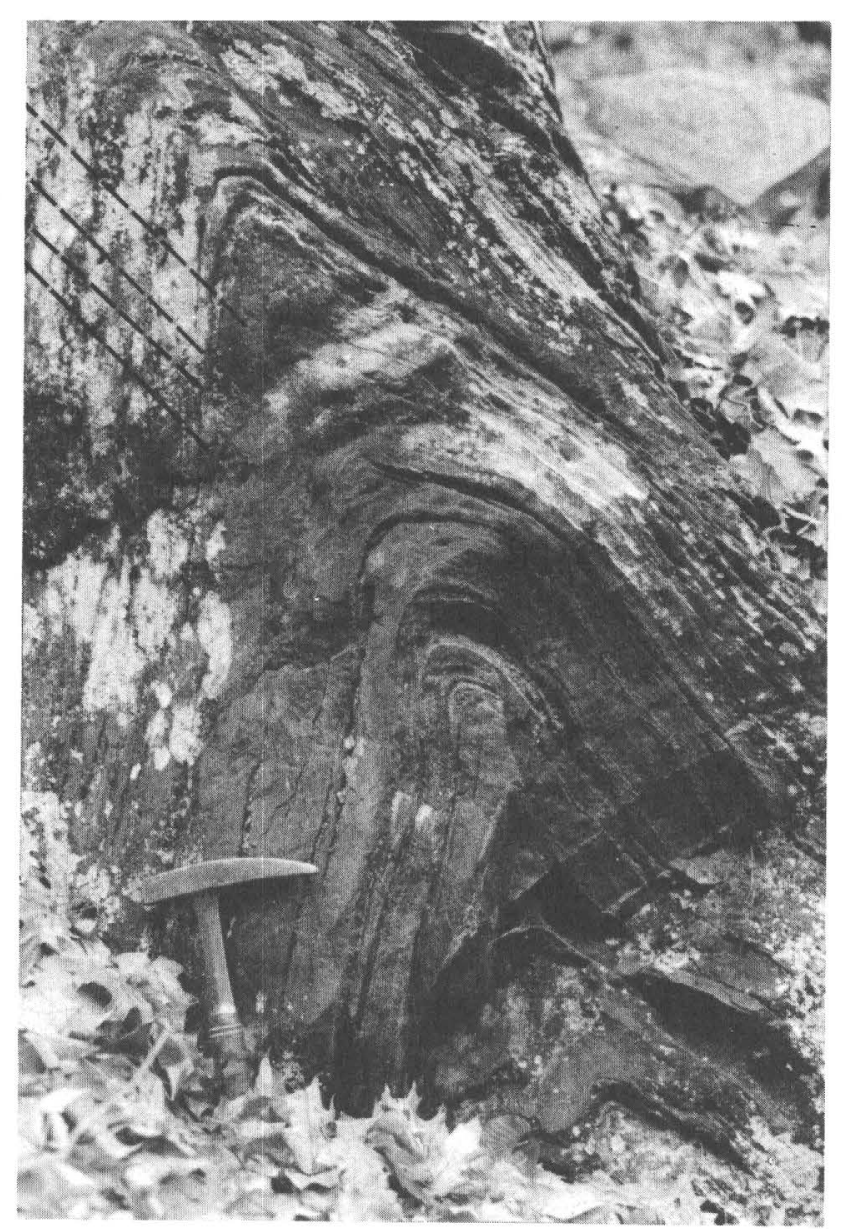

FIgURe 35.-Typical $F_{2}$ minor fold in an amphibolite of the Standing Pond Volcanics in the hinge of the Prospect Hill recumbent fold, Prospect Hill, Dummerston, Vermont. A weak slip cleavage visible (dark lines) in the upper central portion of the photo parallels the axial surface of the fold.

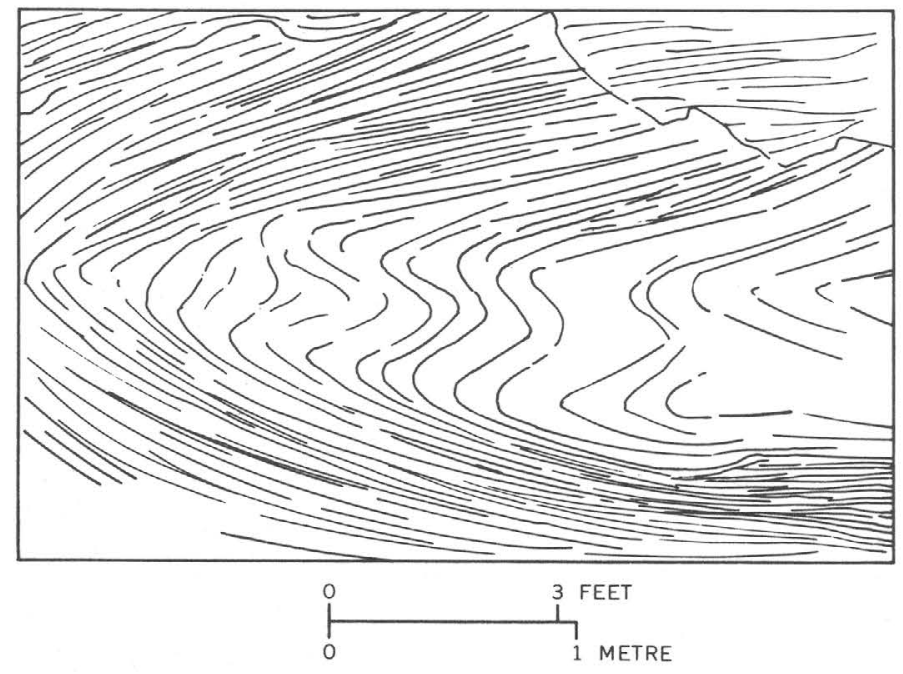

FIGURE 36.- Sketch of an F.: fold in an impure marble bed in the Waits River Formation, Halifax, Vermont.

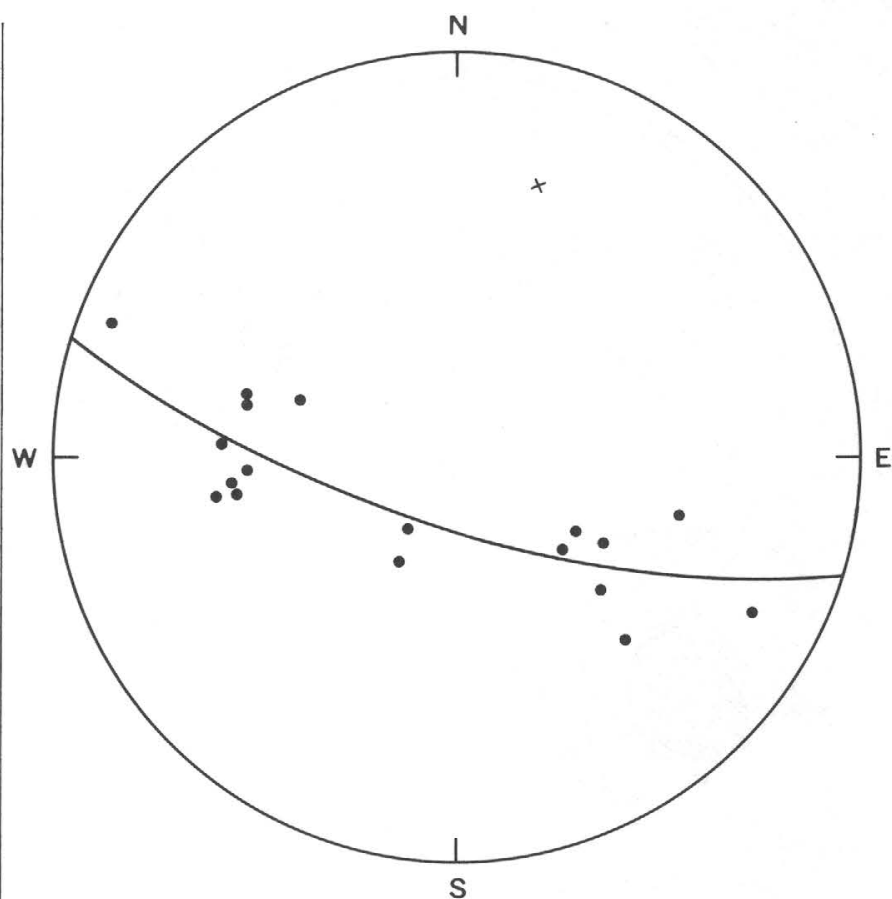

FIGURE 37.-Lower hemisphere stereonet plot of the poles to the axial surfaces of minor $\mathrm{F}_{2}$ folds which deform the Prospect Hill recumbent fold in the north end of the Guilford dome. The poles show a fairly well defined great circle distribution about the axis $(\mathrm{x})$ of the later dome folding.

dip steeply northwest. Bedding $\left(\mathrm{S}_{0}\right)$ and the earlier schistosities $\left(S_{1}\right.$ and $\left.S_{2}\right)$ are folded by the $F_{3}$ folds and transected by the $S_{3}$ slip cleavage. $S_{3}$ results from the realinement of $S_{2}$ and the growth of micas parallel to the axial surfaces of small microcrenulations (fig. 39). White (1949) described similar slip cleavage in detail. Excellent crinkle lineations occur at the intersection of slip cleavage and schistosity in the pelitic rocks.

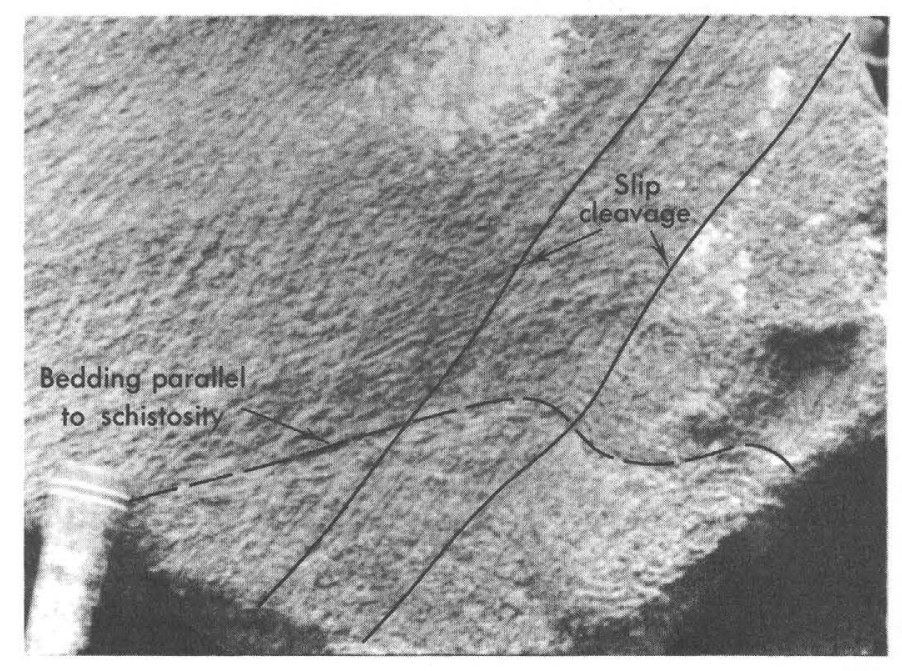

FIGURE 38.-Slip cleavage developed parallel to the axial surface of an open $\mathrm{F}_{3}$ fold, Northfield Formation, Halifax, Vermont. Schistosity parallel to bedding is folded. 


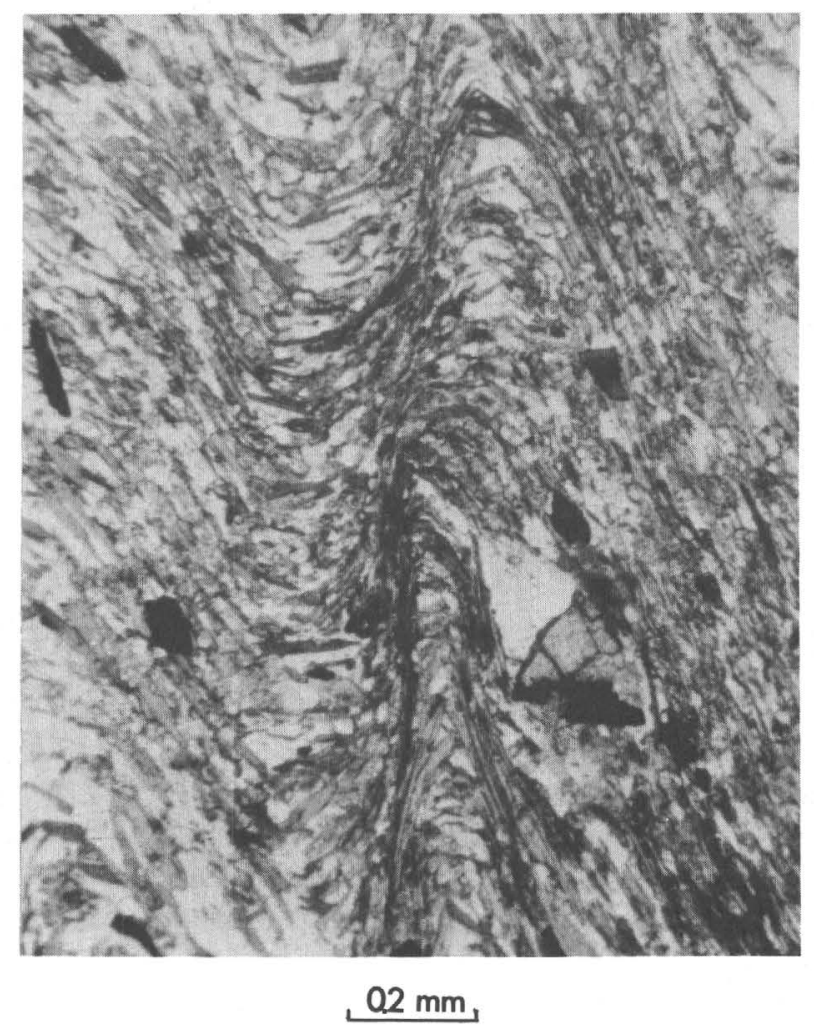

FiguRe 39.-Photomicrograph of crinkles and slip cleavage in mica schist from the Northfield Formation, Brattleboro, Vermont. Slip cleavage parallels the axial surfaces of the $F_{3}$ folds.

$\mathrm{S}_{3}$ is prominently developed in the area where the major foliation changes from east-dipping, off the Green Mountain anticlinorium, to west-dipping, adjacent to the Guilford dome. In this zone, the slip cleavage generally strikes more easterly than the earlier bedding and schistosity. South of the Guilford dome $S_{3}$ is also prominently developed between the Guilford and Colrain domes, where it has a more easterly trend than it has west of the Guilford dome.

$F_{4}$.-The youngest folds throughout most of the area are small-scale open warps or buckles in the schistosity and slip cleavage. These belong to one or more stages of minor folding and have a variety of orientations, of which the most common are subhorizontal axes and gently to moderately dipping axial surfaces. Crinkle lineations may be developed in the hinge areas of these folds.

$F_{5}$.-Only in the eastern part of the area in the Brattleboro syncline were younger folds observed. The Putney Volcanics were affected by a series of northeast-plunging folds large enough to be visible in map pattern (figs. 29 and 32). The folds have moderate to steep plunges with steeply dipping axial surfaces. Most of the folds have a sinistral map pat- tern, showing an east-side-north sense of movement direction.

Kink bands are relatively common in this area and are probably related to this final period of folding. They strike approximately N. $40^{\circ} \mathrm{E}$., across the trend of the Brattleboro syncline, and have axial surface that dip $40^{\circ}-70^{\circ}$ southeast. The kink bands parallel the axial surfaces of very open steeply plunging minor folds that have east-side-north movement patterns. The kink bands and open folds either are related to the mappable $F_{5}$ folds or are younger.

\section{DUMMERSTON FAULT}

A small postkinematic fault that offsets the Putney Volcanics in the northeastern part of the area (fig. 32) is the youngest structural feature in the area. It roughly parallels the strike of the Triassic border fault east of the Connecticut River (fig. 28; Thompson and others, 1968; Trask, 1964) and is therefore probably Triassic in age.

\section{BLACK MOUNTAIN GRANITE}

The Black Mountain Granite, a binary granodiorite correlated with the New Hampshire Plutonic Series (Billings, 1956), intruded the Waits River Formation in the axial region of the northern part of the Guilford dome (fig. 32). The contacts are steeply dipping and sharp, cutting the bedding and schistosity. Numerous dikes and sills of the granite and a contact metamorphic aureole occur within several tens of metres of the main body of the intrusion.

Although most of the regional deformation occurred prior to the granite intrusion, the granite body and many of the medium-grained dikes and sills have a very weak foliation produced by the alinement of fine-grained mica flakes. This foliation generally dips steeply and appears to have developed during the waning stages of the second major stage of the deformation. Most of the characteristics of the granite body are those that Page $(1968$, p. 375) labels as early posttectonic in his subdivision of the New Hampshire Plutonic Series.

Naylor (1971) dated coarse unalined muscovite flakes from the Black Mountain Granite that appear to cut the earlier micas producing the weak foliation. He interprets the $\mathrm{Rb}-\mathrm{Sr}$ dates of 377 and $383 \pm 7$ m.y. (early Middle Devonian) as establishing a minimum age for the intrusion.

\section{DISCUSSION}

The Prospect Hill fold is probably a continuation of the Ascutney sigmoid, as shown by Rosenfeld 
(1968) and Doll and others (1961). If this is true, the hinge of the Prospect Hill fold must turn more northerly a short distance north of Prospect Hill in order to connect with the Ascutney sigmoid in the Saxtons River quadrangle. The Prospect Hill fold also probably continues south-southwest from the Guilford dome area and reappears in the Colrain dome (Rosenfeld, 1968).

The direction of tectonic transport of the Prospect Hill fold is related to the problem of the stratigraphic facing between the Gile Mountain and Waits River Formations. If the Gile Mountain is younger than the Waits River, as has been assumed in this paper, then the Prospect Hill fold is the recumbent syncline beneath an east-facing recumbent anticline. The anticlinal hinge of this recumbent fold would be the early synformal hinge east of the Guilford dome. The Fall Brook anticline and the tongue of Northfield Formation encircling the northern end of the Guilford dome are interpreted as the central part of this recumbent anticline. The anticlinal hinge could possibly parallel the hinge of the Prospect Hill fold, striking approximately N. $45^{\circ}$ E. and plunging northeast and southwest, away from the hinge of the Guilford dome. Southwest of the dome, the anticlinal hinge would turn more to the south.

The minor structural data support the interpretation that the Fall Brook anticline and Northfield Formation north of the Guilford dome are part of the recumbent anticline. Fold axes and lineations in the Fall Brook anticline strike northeast, parallel to the axis of the Prospect Hill fold. The fold axes and lineations in the Northfield Formation north of the Guilford dome also parallel the fold axes and lineations in the synclinal hinge on Prospect Hill. The minor folds in the amphibolites of the Barnard Volcanic Member of the Missisquoi Formation in the core of the Fall Brook anticline have a style similar to those in the Standing Pond Volcanics in the hinges of the Prospect Hill fold. In both of these localities, the minor folds associated with the major structure fold an earlier schistosity, $\mathrm{S}_{1}$. In the schists and thin quartzites of the Northfield Formation, the principal schistosity is parallel to the axial planes of the $F_{2}$ isoclinal folds. $S_{1}$ is only questionably present. This is believed to be the result of the thorough reorientation and recrystallization of the micaceous minerals in the schistose rocks parallel to the axial planes of the $\mathrm{F}_{2}$ isoclinal folds.

The outcrop width of the Northfield Formation in the north-central Brattleboro quadrangle is at least twice as great as its width in the rest of southern and central Vermont (Doll and others, 1961). The width increases where the trace of the proposed recumbent anticlinal fold joins the main Northfield belt. The Northfield-Goshen belt continues southward into Massachusetts at this increased width (Hatch and Hartshorn, 1968; Hatch and others, 1967), suggesting the possible continuation of this fold.

Upright isoclinal folds with wavelengths of 60 $600 \mathrm{~m}$ (200 to $2,000 \mathrm{ft}$ ) have been mapped by Hatch (1968) and Hatch and others (1967) in the Goshen Formation, the Northfield equivalent in western Massachusetts. Here the Goshen has a greater abundance of graded arenaceous beds than does the Northfield Formation in the Guilford dome area. I believe that these folds (Hatch's stage II, 1972 and 1975) are the same generation as the upright isoclinal folds in the Northfield Formation of the Guilford dome area, here assigned to the $\mathrm{F}_{2}$ stage. However, based upon observations in western Massachusetts, Osberg (1972 and 1975) presents a case for placing these upright isoclinal folds (Hatch's stage II) into a different folding sequence whereby they follow a recumbent folding but precede $F_{3}$. If these upright isoclinal folds in the Northfield-Goshen belt are of the $\mathrm{F}_{2}$ stage, then the recumbent folding Osberg proposes in Massachusetts is earlier than the recumbent folding $\left(\mathrm{F}_{2}\right)$ of the Guilford dome area. However, if these two recumbent folding stages are equivalent, it would be necessary to have an additional folding stage present in the Guilford dome area $\left(F_{2.5}\right)$ which produced the upright isoclinal folds in the Northfield.

In the Guilford dome area, evidence suggesting an additional isoclinal folding stage not equivalent to the $\mathrm{F}_{2}$ recumbent folding has not been found. This could be due in part to the lack of well-defined bedling in the Northfield Formation in this area. Also, refolding of the Northfield Formation west of the Guilford dome during the second major stage of deformation has reoriented the isoclinal minor folds associated with $\mathrm{F}_{2}$ into upright attitudes that would be nearly identical in orientation to the folds Osberg proposes. Thus it would be difficult to dis1:inguish if two isoclinal-fold sets were present in this area. In the tongue of the Northfield Formation immediately north and northeast of the Guilford dome (figs. 29 and 32), the isoclinal folds plunge northeastward, parallel to the axis of the Prospect Hill recumbent fold. This supports the interpretation that the Northfield isoclinal folds are congruous with the author's major recumbent folding stage $\left(F_{2}\right)$ and are not a later, north-trending fold generation. 
The slip cleavage $\left(\mathrm{S}_{3}\right)$ that is well developed in the Northfield Formation parallel to the axial surfaces of the $\mathrm{F}_{3}$ folds is also a prominent minor structural feature in the rest of the Northfield-Goshen belt to the south. In the Guilford dome area, it is believed that this slip cleavage formed contemporaneously with the rising Guilford dome. The slip cleavage is best developed to the south and west of the dome, where the rocks were highly flexed during the doming. Maximum flexure in this area would be expected if uplift occurred simultaneously in the Green Mountain anticlinorium and Guilford and Colrain domes.

\section{METAMORPHISM}

Regional metamorphism in the Brattleboro area ranges from greenschist to amphibolite facies (Turner, 1968) in a Barrovian-type metamorphic series. Chlorite, biotite, almandine, and staurolite-kyanite metamorphic zones (fig. 29) have been mapped in the pelitic rocks. The chlorite and biotite zones occur near the central part of the Brattleboro syncline and are continuous with a regional metamorphic low along the Connecticut River valley in Vermont and north-central Massachusetts (Doll and others, 1961; Thompson and Norton, 1968). Westward from the Brattleboro syncline, the grade increases to the staurolite-kyanite zone in the Guilford dome. The remainder of the area is in the almandine zone of regional metamporhism.

\section{RELATION OF METAMORPHISM TO DEFORMATION}

The mapped isograds (fig. 29) indicate that the highest grade of regional metamorphism in the area is centered on the Guilford dome. Kyanite and staurolite porphyroblasts have grown across the $S_{1}$ and $\mathrm{S}_{2}$ foliations, parallel to which minute graphite and quartz grains had been incorporated as inclusion trains. In no case were these porphyroblasts observed to have a rotated or discordant internal schistosity. Thus textural evidence indicates the metamorphic conditions of the staurolite-kyanite zone were reached subsequent to the $\mathrm{F}_{2}$ recumbent folding stage.

The exact temporal relation between the peak of metamorphism and the doming stage of deformation is more difficult to establish. The rise of material in the dome undoubtedly carried heat upward. Whether the metamorphic conditions of the staurolite-kyanite zone were first introduced into the rocks during or after the doming or whether the doming merely carried rocks already at these conditions to their present levels is still a problem. The undeformed nature of the staurolite and kyanite porphy- roblasts suggests that the peak of the metamorphism occurred either late in or following the doming stage of the deformation. Also, staurolite porphyroblasts have grown across the $S_{3}$ slip cleavage. Garnets such as shown in figure 40 give additional evidence that the metamorphism was late. These garnets from the Guilford dome have slightly rotated cores and clear apparently unrotated exteriors. The rotation axis of the core of the garnet in figure 40 lies in the plane of schistosity; the direction and amount of rotation is consistent with its having been formed during the doming phase of deformation (Rosenfeld, 1968). A detailed zoning profile across this garnet (fig. 41) indicates that there is no break or reversal in the zoning. The continuous zoning from rolled through unrolled parts in this garnet is interpreted to mean that the metamorphism outlasted the major deformation in the Guilford dome area. However, if the rotated part of this garnet grew during the $\mathrm{F}_{2}$ recumbent-folding stage and not during the doming stage, the peak of metamorphism could have been reached during a quiescent period prior to the doming. This could only be true if no rotation of the garnet, staurolite, and kyanite porphyroblasts occurred during the doming, which seems unlikely in the light of Rosenfeld's (1968) studies indicating that rotated garnets grew during doming in the Saxtons River area directly north of the Guilford dome area.

The exact relations between the peak of metamorphism and the $F_{4}$ and $F_{5}$ stages of minor folding

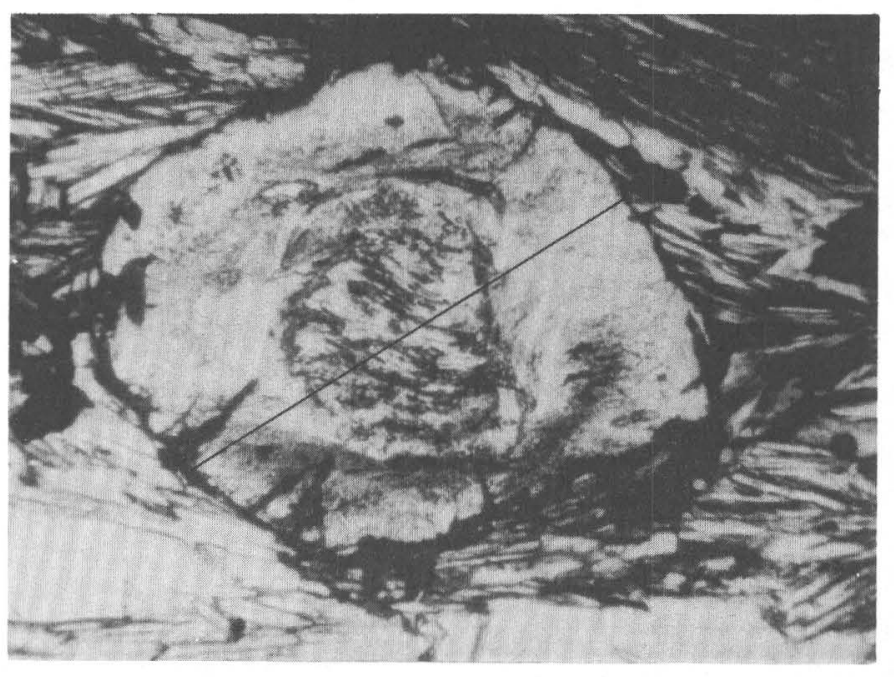

Figure 40.-Photomicrograph of a garnet from the Gile Mountain Formation, Guilford, Vermont. The interior of the garnet shows syntectonic growth. The clear unrolled exterior grew after deformation had ceased. Line indicates the electron microprobe traverse shown in figure 41 . The garnet is approximately $1 \mathrm{~mm}$ in diameter. 


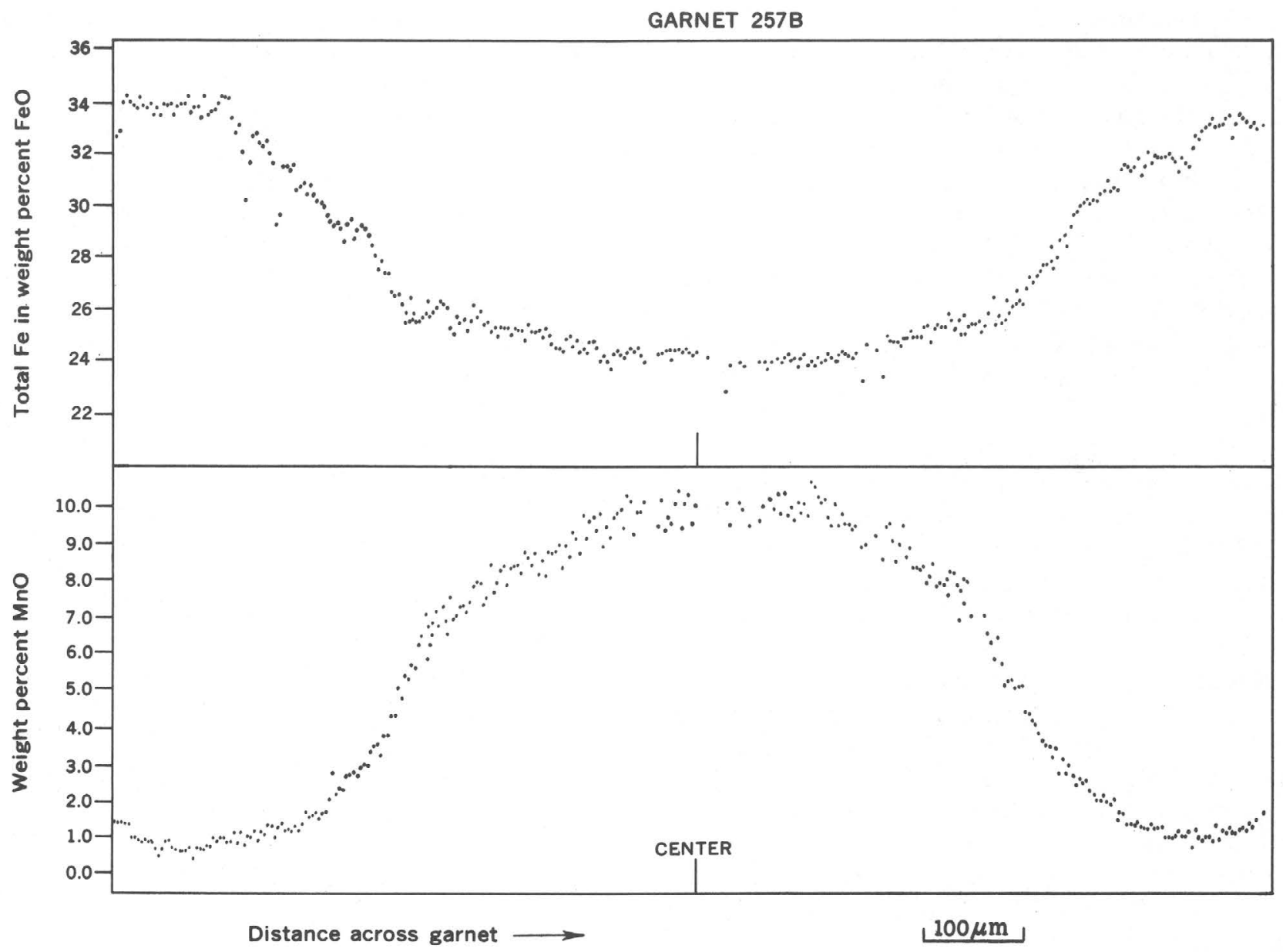

Figure 41.-Plot of the variation in weight percent $\mathrm{FeO}$ and $\mathrm{MnO}$ determined by the electron microprobe traverse across the zoned garnet in figure 40 . The garnet has a rolled central portion surrounded by a clear, unrolled exterior. The analysis is from a thin section which probably did not pass through the exact center of the garnet, thus causing the curves to appear somewhat flattened.

have not been determined, although it appears likely that the metamorphic peak preceded at least the $F_{5}$ folding. The kink bands along the eastern edge of the area may possibly be related to the postkinematic faulting, as has been suggested by Rumble (1969).

Rosenfeld (1968) found that syntectonic garnets grew during the folding of the Ascutney sigmoid (correlated with $\mathrm{F}_{2}$ ) in the Saxtons River quadrangle to the north but that no minerals of higher metamorphic grade are associated with the recumbent fold in this area. This suggests that the extent of metamorphism prior to and during the development of the Prospect Hill fold was no higher than that of the garnet zone. The schistosity formed prior to $F_{2}$ indicates that the temperature was at least great enough for mica recrystallization.

The emplacement of the Black Mountain Granite followed most of the deformation in the area, as shown above. It is believed that the contact aureole developed as a local hot spot nearly synchronously with the regional metamorphism.

\section{AGE OF METAMORPHISM AND DEFORMATION}

The metamorphism and deformation of the Devonian and Silurian rocks in the Guilford dome area occurred during the Acadian orogeny. Metamorphosed and deformed rocks of the Littleton Formation in New Hampshire contain Early Devonian fossils (Boucot and Arndt, 1960; Billings, 1956). The Triassic deposits in north-central Massachusetts are unmetamorphosed and truncate the older metamorphic rocks. In the Brattleboro area, the Rib-Sr dates on coarse muscovites from the Black Mountain Granite (377 and $383 \pm 7$ m.y.) place an upper limit of early Middle Devonian on the major phases of the orogenesis. 
TABLE 1.-Summary of Acadian minor folds, major structures, and metamorphism, Guilford dome area

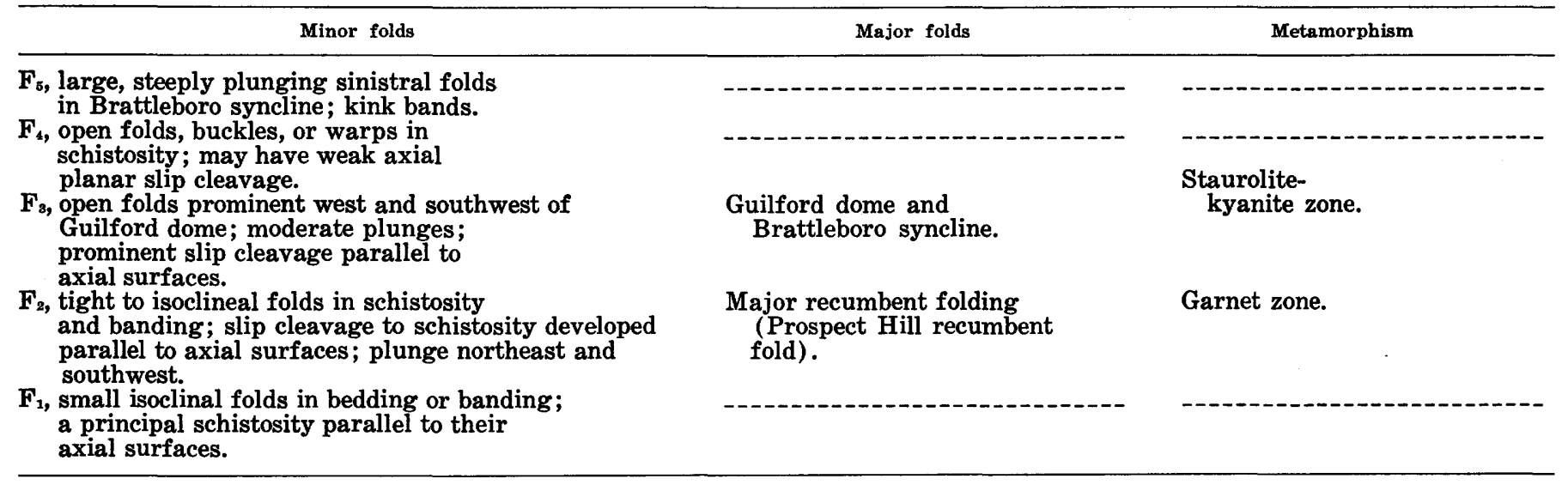

\section{SUMMARY}

The tectono-metamorphic chronology (table 1) of the Guilford dome area centers around two major stages of deformation (fig. 42). First the Prospect Hill recumbent fold formed congruously with the $F_{2}$ stage of minor folding during the first major deformational stage. The recumbent folding affects a previously developed schistosity that is parallel to the axial surfaces of the $F_{1}$ minor folds. The garnet grade of metamorphism was not exceeded during the recumbent folding.

Subsequent to the recumbent folding, the rising of the Guilford dome arched the axial surface of the recumbent fold and probably produced the $\mathrm{F}_{3}$ minor folds and related prominent slip cleavage. Staurolite-kyanite zone metamorphism is associated with the formation of the dome. The $F_{4}$ and $F_{5}$ folds are late minor-folding stages; at least the $F_{5}$ stage postdated the peak of metamorphism. With the possible exception of the $F_{5}$ minor folds, the deformation and metamorphism are related to the Acadian orogeny.

\section{ACKNOWLEDGMENTS}

This work was started as part of a Ph.D. thesis at Harvard University under the direction of Professors Marland P. Billings, James B. Thompson, Jr., and John Haller, to all of whom I would like

Figure 42.-Schematic cross sections showing the evolution of the structural features in the two major stages of deformation in the Guilford dome area. The Standing Pond Volcanics is shown in black. $A$, Prospect Hill fold at the end of the first major stage of deformation, before the rise of the Guilford dome. The dashed line rereesnts a hypothetical staurolite or kyanite isograd. $B$, Prospect Hill fold following the end of the second major stage of deformation, after the rise of the Guilford dome. The horizontal line represents the present erosion surface. The dashed lines show the assumed present distribution of isograds. to express my gratitude for their assistance. I thank Professor John Rosenfeld for spending many days in the field with me and for his thought-provoking discussions. Thanks are also extended to David

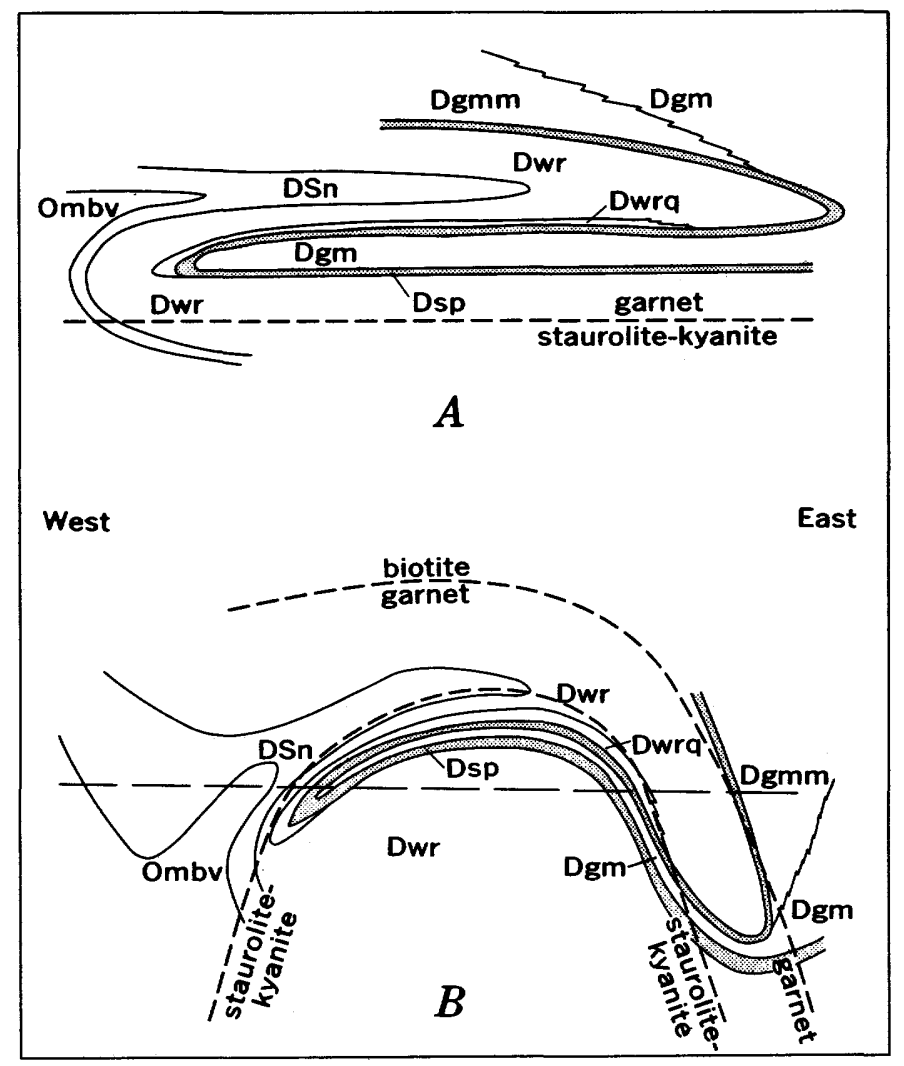

\section{EXPLANATION}

Dgm, Gile Mountain Formation

Dgmm, Gile Mountain Formation, marble member

Dsp, Standing Pond Volcanies

Dwr, Waits River Formation

Dwrq, Waits River Formation, quartzitic member

DSn, Northfield Formation

Ombv, Barnard Volcanic Member, Missisquoi Formation 
Walker, Ray Ingersoll, and Jerry Platt for assistance in the field. I appreciate the thoughtful comments and suggestions of D. S. Harwood, N. L. Hatch, Jr., and Judith Rehmer, who critically reviewed the manuscript.

\section{REFERENCES CITED}

Balk, Robert, 1956, Bedrock geology of the Massachusetts portion of the Bernardston quadrangle, MassachusettsVermont: U.S. Geol. Survey Geol. Quad. Map GQ-90.

Billings, M. P., 1954, Structural Geology (2nd ed.) : Englewood Cliffs, New Jersey, Prentice-Hall, Inc. 514 p.

- 1956, Bedrock geology, part 2 of the geology of New Hampshire: Concord, New Hampshire State Plan. Devel. Comm., $203 \mathrm{p}$.

Billings, M. P., Rodgers, John, and Thompson, J. B., Jr., 1952, Geology of the Appalachian Highlands of east-central New York, southern Vermont, and southern New Hampshire, in Geol. Soc. America, 65th Ann. Mtg., Nov. 10-12, 1952, Guidebook for field trips in New England, p. 1-71.

Boucot, A. J. and Arndt, Robert, 1960, Fossils of the Littleton Formation (Lower Devonian) of New Hampshire: U.S. Geol. Survey Prof. Paper 334-B, p. 41-51.

Cady, W. M., 1960, Stratigraphic and geotectonic relationships in northern Vermont and southern Quebec: Geol. Soc. America Bull., v. 71, p. 531-576.

1969, Regional tectonic synthesis of northwestern New England and adjacent Quebec: Geol. Soc. America Mem. $120,181 \mathrm{p}$.

Chang, P. H., Ern, E. H., Jr. and Thompson, J. B., Jr., 1965, Bedrock geology of the Woodstock quadrangle, Vermont: Vermont Geol. Survey Bull. 29, 65 p.

Doll, C. G., Cady, W. M., Thompson, J. B., Jr., and Billings, M. P. compilers and eds., 1961, Centennial geologic map of Vermont: Vermont Geol. Survey, scale 1:250,000.

Hall, L. M., 1959, The geology of the St. Johnsbury quadrangle, Vermont and New Hampshire: Vermont Geol. Survey Bull. 13, 105 p.

Hatch, N. L., Jr., 1968, Isoclinal folding indicated by primary sedimentary structures in western Massachusetts, in Geological Survey Research 1968: U.S. Geol. Survey Prof. Paper 600-D, p. D108-D114.

- 1972, Tectonic history of part of the east limb of the Berkshire anticlinorium, Massachusetts [abs.]: Geol. Soc. America Abs. with Programs, v. 4, no. 1, p. 19-20.

- 1975, Tectonic, metamorphic, and intrusive history of part of the east side of the Berkshire massif, Massachusetts, in Tectonic studies in the Berkshire massif, western Massachusetts, Connecticut, and Vermont: U.S. Geol. Survey Prof. Paper 888-D, p. 51-62.

Hatch, N. L., Jr., and Hartshorn, J. H., 1968, Geologic map of the Heath quadrangle, Massachusetts-Vermont: U.S. Geol. Survey Geol. Quad. Map GQ-735.

Hatch, N. L., Jr., Osberg, P. H., and Norton, S. A., 1967, Stratigraphy and structure of the east limb of the Berkshire anticlinorium in New England Intercollegiate Geol. Conf., 59th Ann. Mtg., Oct. 13-15, 1967, Guidebook for field trips in the Connecticut Valley of Massachusetts: Amherst, Mass. p. 7-16.

Hepburn, J. C., 1972, Geology of the metamorphosed Paleo- zoic rocks in the Brattleboro area, Vermont: Unpub. $\mathrm{Ph}$. D. thesis, Harvard University, $342 \mathrm{p}$.

Moore, G. E., Jr., 1949, Structure and metamorphism of the Keene-Brattleboro area, New Hampshire-Vermont: Geol. Soc. America Bull., v. 60, p. 1613-1670.

Naylor, R. S., 1971, Acadian orogeny-an abrupt and brief event: Science, v. 172, p. 558-560.

Osberg, P. H., 1972, Recumbent folding of the Goshen and Waits River Formations, western Massachusetts [abs.]: Geol. Soc. America Abs. with Programs, v. 4, no. 1, p. 3738.

1975, Recumbent folding of the Goshen and Waits River Formations, western Massachusetts, in Tectonic studies in the Berkshire massif, western Massachusetts, Connecticut, and Vermont: U.S. Geol. Survey Prof. Paper 888-E, p. $63-68$.

Page, L. R., 1968, Devonian plutonic rocks in New England in Zen E-an, White, W. S., Hadley, J. B., and Thompson, J. B., Jr., eds., Studies of Appalachian geology-northern and maritime: New York, Interscience Publishers, p. 371383.

Ramsey, J. C., 1962, The geometry of conjugate fold systems: Geol. Mag., v. 99, p. 516-526.

1967, Folding and fracturing of rocks: New York, McGraw-Hill Book Co., 568 p.

Rosenfeld, J. L., 1954, Geology of the southern part of the Chester dome, Vermont: Unpub. Ph. D. thesis, Harvard University, $303 \mathrm{p}$.

1960, Rotated garnets and the diastrophic-metamorphic sequence in southeastern Vermont [abs.]: Geol. Soc. America Bull., v. 71, p. 1960.

1965, Further evidence of the nature of the major diastrophism in southeastern Vermont [abs.]: Geol. Soc. America Spec. Paper 82, p. 167.

1968, Garnet rotations due to the major Paleozoic deformations in southeast Vermont, in Zen, E-an, White, W. S., Hadley, J. B. and Thompson, J. B., Jr., eds., Studies of Appalachian geology-northern and maritime: New York, Interscience Publishers, p. 185-202.

Rumble, D., 1969, Stratigraphic, structural, and petrologic studies in the Mt. Cube area, New Hampshire-Vermont: Unpub. Ph. D. thesis, Harvard University, 119 p.

Segerstrom, Kenneth, 1956, Bedrock geology of the Colrain quadrangle, Massachusetts-Vermont: U.S. Geol. Survey Geol. Quad. Map GQ-86.

Skehan, J. W., 1961, The Green Mountain anticlinorium in the vicinity of Wilmington and Woodford, Vermont: Vermont Geol. Survey Bull. 17, 159 p.

Thompson, J. B., Jr., 1950, A gneiss dome in southeastern Vermont: Unpub. Ph.D. thesis, Massachusetts Institute of Technology, $160 \mathrm{p}$.

Thompson, J. B., Jr. and Norton, S. A., 1968, Paleozoic regional metamorphism in New England and adjacent areas: in Zen, E-an, White, W. S., Hadley, J. B., and Thompson, J. B., Jr., eds., Studies of Appalachian geology-northern and maritime: New York, Interscience Publishers, p. 319327.

Thcmpson, J. B., Jr., Robinson, Peter, Clifford, T. N., and Trask, N. J., Jr., 1968, Nappes and gneiss domes in westcentral New England in Zen, E-an, White, W. S., Hadley, 
J. B., and Thompson, J. B., Jr., eds., Studies of Appalachian geology-northern and maritime: New York, Interscience Publishers, p. 203-218.

Trask, N. J., 1964, Stratigraphy and structure in the VernonChesterfield area, Massachusetts, New Hampshire, and Vermont: Unpub. Ph.D. thesis, Harvard University, 99 p.
Turner, F. J., 1968, Metamorphic petrology: New York, McGraw-Hill Book Co., 403 p.

White, W.S., 1949, Cleavage in east-central Vermont: Am. Geophys. Union Trans., v. 30, p. 587-594.

White, W. S. and Jahns, R. H. ,1950, Structure of central and east-central Vermont: Jour. Geol., v. 58, p. 179-220. 



\section{Tectonic Metamorphic, and Intrusive History of Part of the East Side of the Berkshire Massif, Massachusetts}

By NORMAN L. HATCH, JR.

TECTONIC STUDIES OF THE BERKSHIRE MASSIF, WESTERN MASSACHUSETTS, CONNEGTICUT, AND VERMONT

GEOLOGICAL S URVEY PROFESSIONAL PAPER $888-$ D

Prepared in cooperation with the

Commonwealth of Massachusetts

Department of Public Works

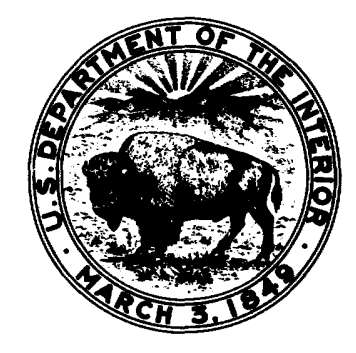





\section{CONTENTS}

Abstract
Introduction
Tectonic history
$\quad$ Stage I
$\quad$ Stage II
$\quad$ Stage III

Page

51

51

52

52

52

54
Testonic history-Continued

$$
\text { Stage IV }
$$

Metamorphism _._-

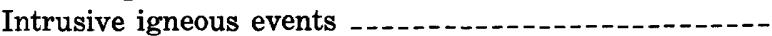

Summary -..- -

Acknowledgments -...-.

References cited
Page

56

57

60

61

61

62

\section{ILLUSTRATIONS}

Figure 43. Index map of west-central New England

44. Generalized geologic map of the study area

45. Photomicrographs of pelitic Rowe Schist

46. Geologic map and section of stage II isoclinal folds

47. Photomicrograph of schist of Goshen Formation showing stage III folds and cleavage

48. Generalized geologic map of study area showing representative stage II, III, and IV minor folds -...-

49. Photomicrographs of mineral growth parallel to stage II schistosity

50. Photomicrographs of biotite deformed by stage III

51. Photomicrograph of garnet porphyroblast

52. Photomicrograph of staurolite porphyroblast

53. Photomicrograph of staurolite porphyroblast

54. Photomicrographs of post-stage III porphyroblasts

55. Diagram of time and space relations of Acadian events

\section{TABLES}

TABLE 1. Summary of characteristics of the four stages of deformation 



\title{
TECTONIC, METAMORPHIC, AND INTRUSIVE HISTORY OF PART OF THE EAST SIDE OF THE BERKSHIRE MASSIF, MASSACHUSET'TS
}

\author{
By Norman L. Hatch, JR.
}

\begin{abstract}
Four stages of regional deformation are recognized east of the Precambrian Berkshire massif in western Massachusetts. Stage $I$ is inferred to have produced folds in pre-Silurian rocks during the Taconic orogeny. Stage II formed large and small north-trending isoclinal folds that have schistosity in Cambrian through Lower Devonian rocks. Stages III and IV formed small, more open, northeast- and north-trending folds, respectively, both having slip cleavage. Stages II, III, and probably IV are Acadian. Regional metamorphism reached biotite grade during stage II, garnet grade after stage II, and staurolite and kyanite grades after stage III. Ultramafic rocks were intruded before stage II, probably during the Taconic orogeny. The indistinctly foliated Middlefield Granite was probably intruded early in stage II. The unfoliated sills of Williamsburg-type granite and pegmatite were probably emplaced near the peak of metamorphism, immediately after stage III.
\end{abstract}

\section{INTRODUCTION}

This chapter describes the tectonic, metamorphic, and intrusive history of most of the block of ten $71 / 2$-minute quadrangles outlined on figure 43 on the east side of the Berkshire massif in Massachusetts. About $65 \mathrm{~km}^{2}$ in the south-central part of the area that have been studied by Stanley (1975) are excluded from this discussion.

The stratified rocks in the area are a typical eugeosynclinal sequence of shale, graywacke, and felsic and mafic volcanic rock of Early Cambrian to Early Devonian age, regionally metamorphosed to garnet grade in the northern part and staurolite and kyanite grades in the central and southern parts of the area. Sillimanite-grade rocks in the southernmost part of the area have been studied by Stanley (1967, 1975) and S. F. Clark, Jr. (unpub. data, 1972), and are not included in the present discussion. Intrusive igneous rocks are small lenses of ultramafic rock, two granitic bodies a few kilometres in diameter, and hundreds of small sills of pegmatite and granite

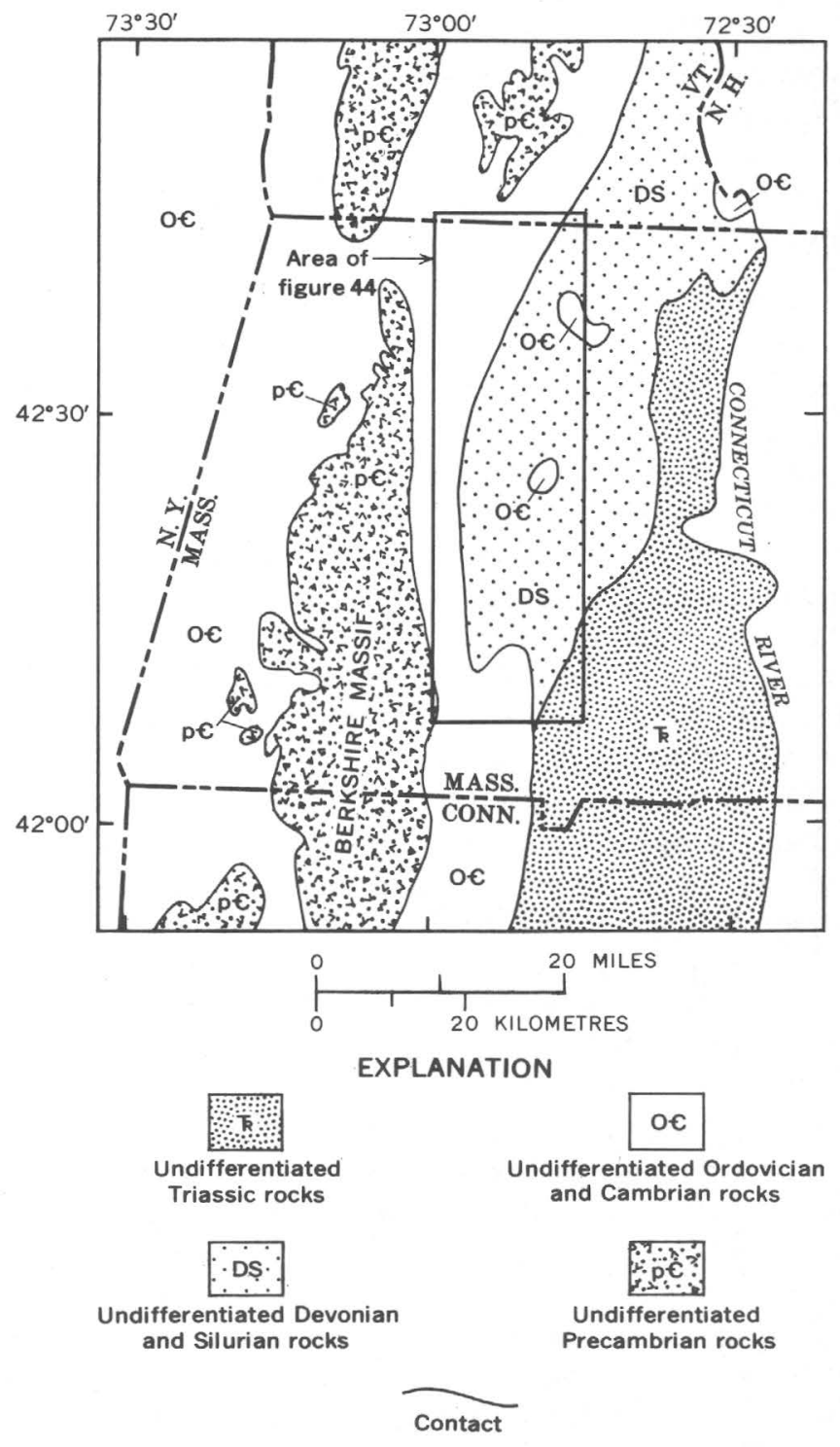

Figure 43.-Index map of west-central New England showing location and geologic setting of study area. 
in the southeastern part of the area. More detailed descriptions of these rocks are available in quadrangle maps (for example, Osberg and others, 1971; Chidester and others, 1967; Hatch and others, 1970; Hatch, 1969) and reports cited therein.

This chapter discusses the tectonic history of the area and, insofar as possible, relates the tectonic events to the various episodes of metamorphism and igneous intrusion. These relations have been deduced from an analysis of the pattern of map-unit boundaries, fold axial traces, and isograds; field observations of minor folds and their associated structures; and microscopic study of cleavages, crenulate folds, and porphyroblasts.

\section{TECTONIC HISTORY}

Figure 44 is a generalized geologic map of the area outlined in figure 43. Four stages of regional folding are interpreted for this area. A fifth stage, localized around a small body of intrusive gneiss northwest of Plainfield, was discussed by Osberg, and others (1971).

\section{STAGE I}

The earliest stage of deformation, stage I, is inferred to have produced widespread folds in the pre-Silurian rocks. No large folds of this generation have been recognized within the area, but a few small folds in the Middle Ordovician Moretown Formation have been assigned to it. Although these now have generally east-trending axial surfaces and variably plunging axes, their original orientation cannot be ascertained because of the subsequent deformation. They have no presently recognizable axial-surface cleavage. They are distinguished from folds of the other stages and assigned to stage I (Taconic age) because they are cut by axial-surface schistosity of stage II and because they are restricted to pre-Silurian rocks. The present scarcity of stage I folds is attributed to obliteration by subsequent deformation. Stage I cleavage may also have been obliterated or may have never existed.

Ratcliffe and Harwood (1975), and Norton (1975) have ascribed a Taconic age to major tectonic and metamorphic events to the west and southwest. Field discussions with S. A. Norton suggest that, in the Precambrian and Lower Cambrian rocks along and immediately west of the western edge of the area of figure 44, stage I schistosity is well developed and is parallel or nearly parallel to the nearly equally well developed stage II schistosity. Thus, the intensity of stage I in the western part of the area of this report is difficult to assess, both because of the masking effect of the later Acadian deformations and because the Taconic deformation appears to decrease abruptly in intensity eastward from the areas of Ratcliffe's, Harwood's, and Norton's mapping (whereas the Acadian deformation appears less intense in their areas). The intercalation of Hoosac and Precambrian rocks in the southwest part of the area may have resulted from westward thrusting nearly parallel to bedding at and near the Precambrian-Hoosac contact during the Taconic orogeny, as suggested by Norton (1971, $1975)$ for the area immediately to the west. The apparent southward change of the Lower Cambrian to Lower Ordovician Pinney Hollow, Ottauquechee, and Stowe Formations in southern Vermont to a sequence of interlensing Pinney Hollow-, Ottauquechee-, and Stowe-like rocks defined at the Rowe Schist in Massachusetts has been considered a sedimentary change (Hatch and others, 1966). A possible alternative interpretation is that the apparent lenses are thrust slices in a major Taconic fault zone that encompasses most or all of the Rowe Schist in Massachusetts.

\section{STAGE II}

The most conspicuous and widespread secondary structure throughout the study area is a well-developed schistosity formed largely by parallel plates of fine-grained muscovite, elongate grains of quartz, and, in rocks of appropriate composition, carbonaceous material, chlorite, and biotite (fig. 45).

This schistosity is present in all stratified rocks of Early Cambrian through Early Devonian age. It is parallel to the axial surfaces of generally tight to isoclinal folds and is, therefore, parallel or nearly parallel to bedding except near fold hinges. The amplitude and wavelength of the folds vary greatly from formation to formation, presumably as a function of lithic type. In thin-bedded $(0.3-1.0 \mathrm{~cm})$ rocks, such as characterize much of the Ordovician Moretown Formation, small folds a few centimetres in amplitude are nearly ubiquitous and large folds are rare. In the well-bedded $(2-10 \mathrm{~cm})$ and graded bedded rocks of the Goshen Formation (Devonian and Silurian), however, small folds are rare, and large isoclinal folds with amplitudes of a few thousand metres and wavelengths of about $100 \mathrm{~m}$ have been mapped over all but the eastern part of the area of the Waits River and Goshen Formations shown in figure 44 . Figure 46 shows some typical folds in the Goshen.

The interpretation of these isoclinal folds is supported not only by the map pattern of the two lithic units shown in figure 46 but more importantly by abundant sedimentary structures (mainly graded 
EXPLANATION
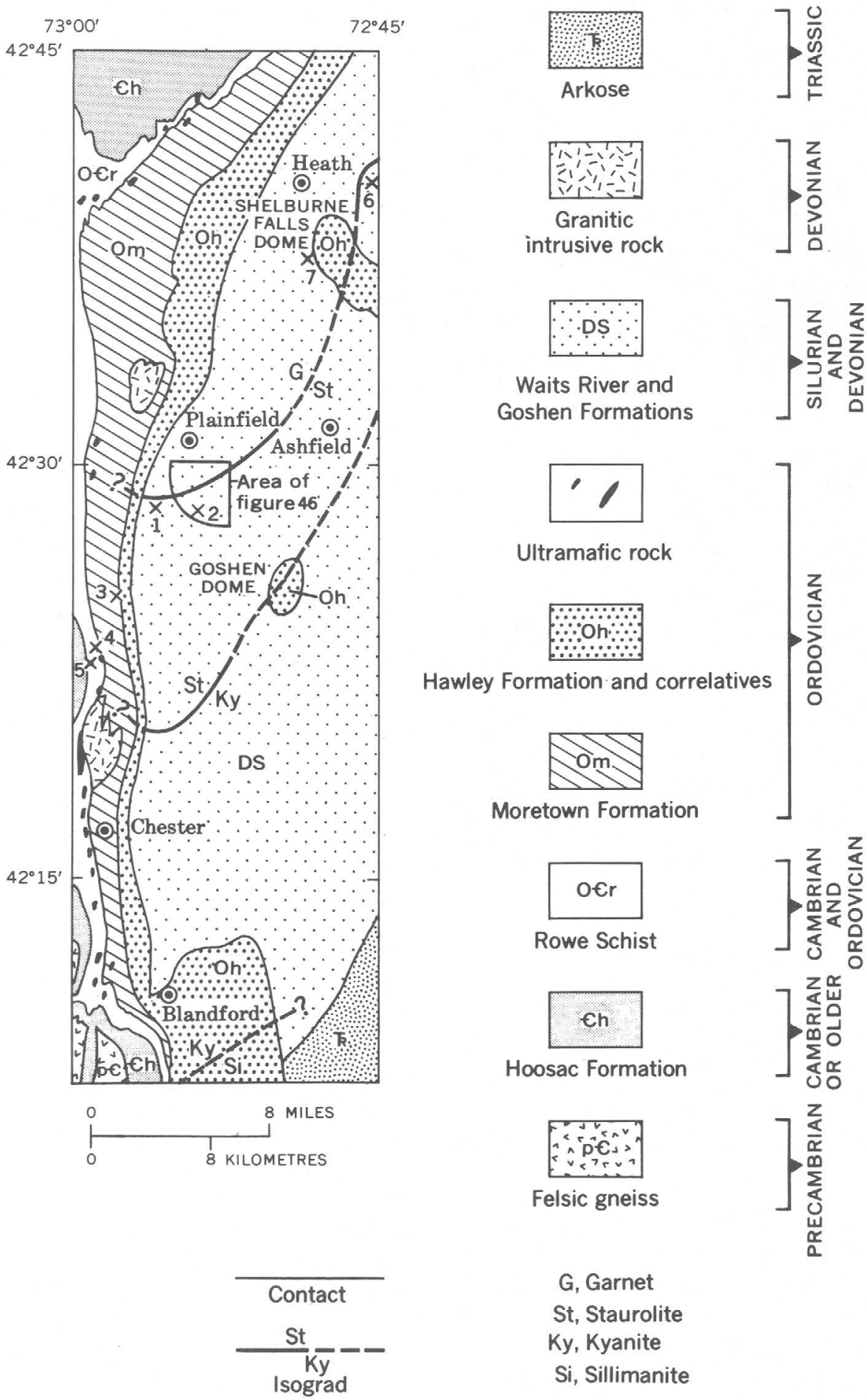

G, Garnet

St, Staurolite

Ky, Kyanite

Si, Sillimanite

Dashed where inferred

$\times 7$ Sample locality

FIGURE 44.-Generalized geologic map of the study area. 

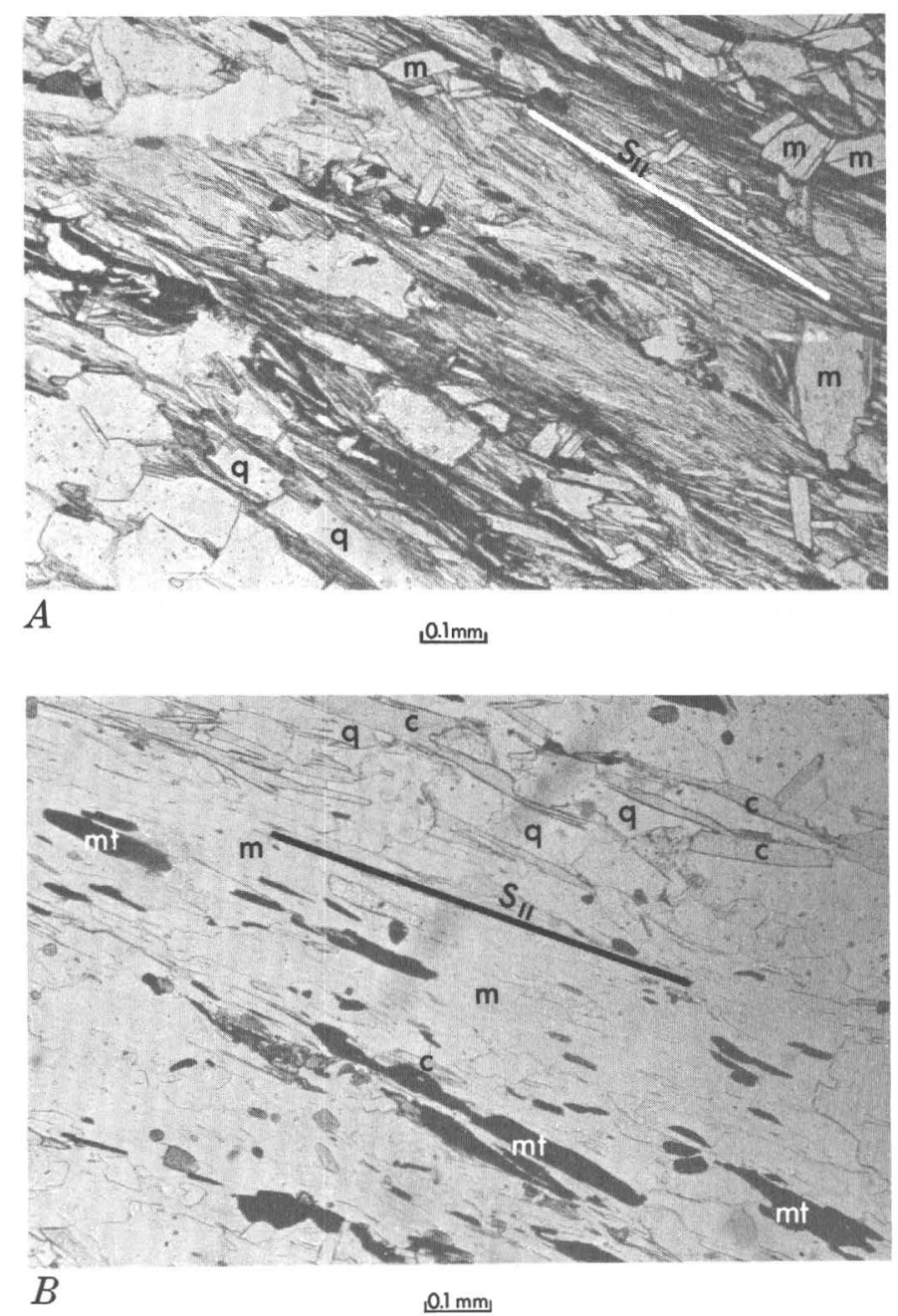

FIgURE 45.-Photomicrographs of pelitic Rowe Schist showing stage II schistosity $\left(\mathrm{S}_{1 \mathrm{II}}\right)$. $A$, locality 5 , figure 44 . Carbonaceous schist; schistosity formed by muscovite, carbonaceous material, and elongate quartz (q). Younger porphyroblastic muscovite $(\mathrm{m})$ crosscuts schistosity. Crossed polarizers. $B$, locality 4, figure 44. Green noncarbonaceous schist; schistosity formed by muscovite $(\mathrm{m})$, chlorite (c), tabular opaque grains (largely magnetite, $\mathrm{mt}$ ), and quartz (q). Planepolarized light.

beds) that indicate the direction of stratigraphic tops (Hatch, 1968). In the area of figure 46 and, indeed, in most of the area of Goshen rocks in figure 44 , the tops data, the minor folds, and the map pattern of the major folds indicate that the beds were upright and probably nearly flat lying at the time of isoclinal folding. Osberg $(1972,1975)$, however, has pointed out that in a few exposures near the town of Heath (fig. 44) in the Heath quadrangle (Hatch and Hartshorn, 1968), beds were apparently upside down prior to isoclinal folding, suggesting an episode of recumbent folding of the Goshen (and overlying Waits River) beds before stage II. A few kilo- metres west and northwest of Ashfield (fig. 44), graded bedding in stage II folds studied by the author suggests that beds at a few localities were upside down at the time of isoclinal folding, whereas at others they were right side up.

These overturned beds have been discussed in detail by Osberg (1975), but two points need to be dealt with here. First, the recumbent folding must have occurred between stages I and II as used in this chapter. This period of folding was not assigned to a separate stage because I was not aware of Osberg's $(1972,1975)$ evidence until after the abstract from which this chapter evolved (Hatch, 1972) was submitted, so that a change in numbering would be confusing. Second, Hepburn (1975) has described an episode of recumbent folding in nearby southeast Vermont that followed rather than preceded major steep isoclinal folding and development of strong axial-surface schistosity in Devonian and Silurian rocks. Thus, the order of recumbent and steep isoclinal folding in southeast Vermont is reversed from that in the area of this report, and correlation of these periods of folding is in doubt.

Throughout most of the area, the axes of stage II folds are subhorizontal in Devonian and Silurian rocks. In Ordovician and Cambrian rocks, however, most axes are steeply plunging and are randomly oriented in both direction and amount of plunge. These relationships are inferred to have resulted from superposition of stage-II folding onto previously deformed (by stage I) Ordovician and Cambrian rocks and previously undeformed, or at least generally horizontal, Devonian and Silurian rocks. Thus, the attitudes of stage II fold axes offer evidence for the existence of stage I.

The tectonic discontinuity between pre-Silurian and Devonian and Silurian rocks is complicated by an inferred décollement at the base of the Goshen Formation. This décollement offers the only satisfactory explanation for the large isoclinal folds in the Goshen rocks and their absence in the underlying Ordovician and Cambrian rocks. Although no evidence of movement along the décollement was recognized in the many exposures of the unconformity, the geometry of the folds above and below it requires some slippage, but its extent cannot be reliably determined.

\section{STAGE III}

Throughout most of the area, the strong regional schistosity of stage II is cut by a well-developed slip cleavage that has been assigned to stage III (fig. 47). This slip cleavage consistently strikes northeast and dips moderately northwest. It is parallel to 


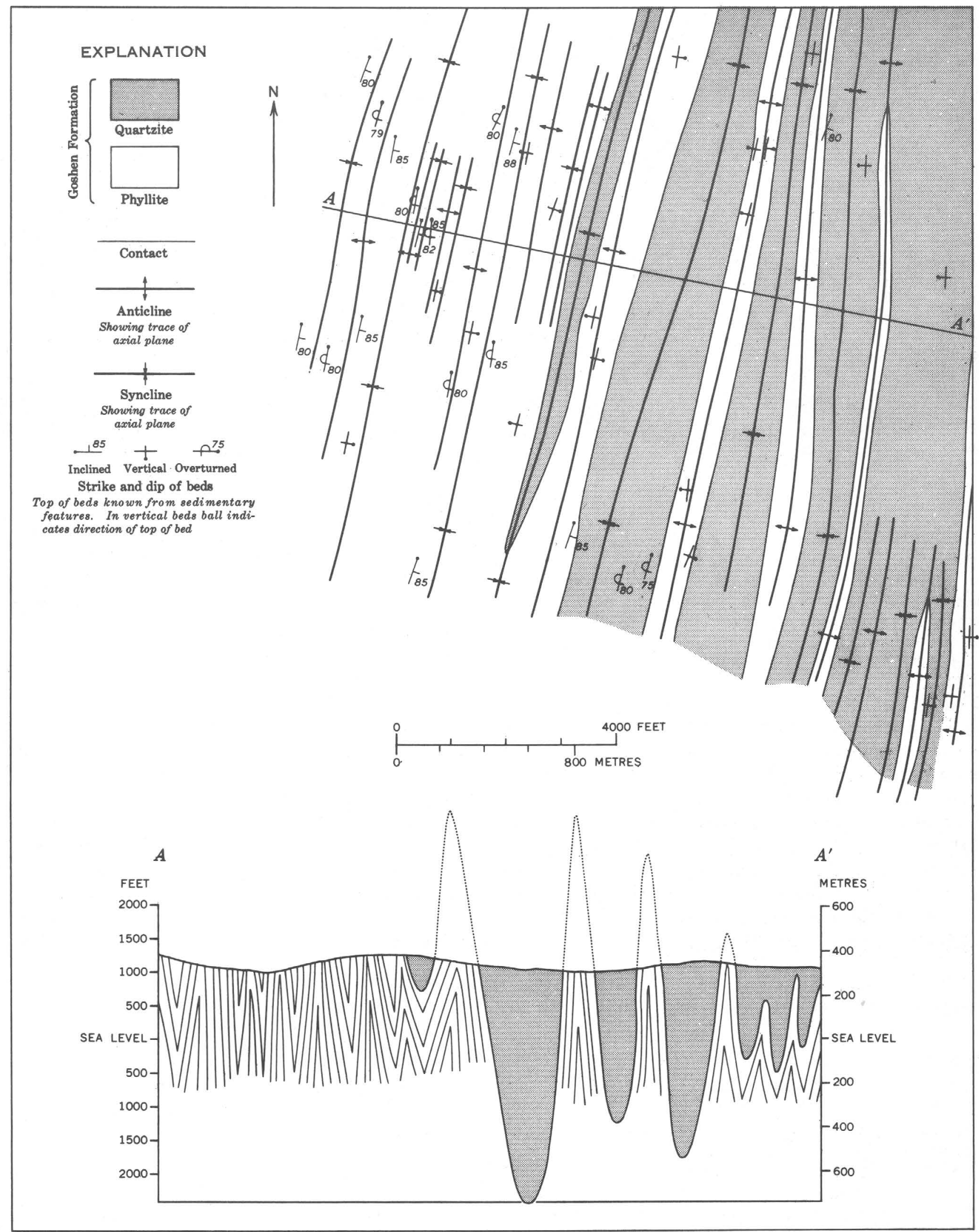

FIGURE 46.-Geologic map and section showing typical stage II isoclinal folds in the Goshen Formation in the central part of the area. Area of figure 46 shown on figure 44. From Hatch (1968). 


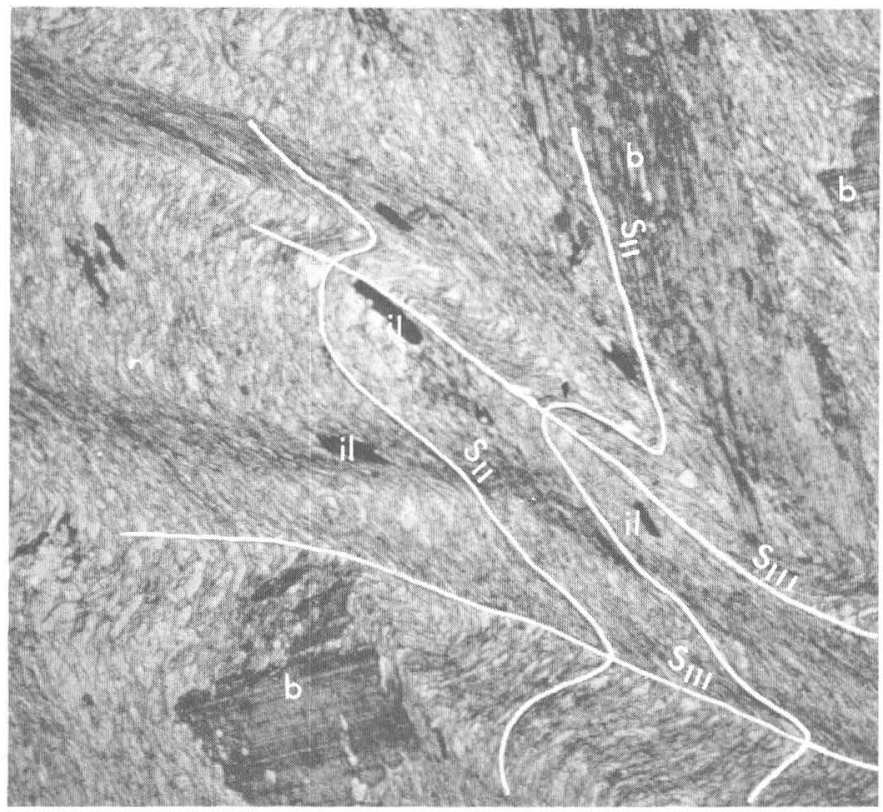

$0.1 \mathrm{~mm}$

FiguRE 47.-Photomicrograph of carbonaceous pelitic schist of the Goshen Formation showing stage III crenulate folds and slip cleavage $\left(S_{I I I}\right)$ deforming stage II schistosity $\left(S_{I I}\right)$. Locality 2, figure 44. Note deflection of slip cleavage around porphyroblast of biotite (b). Note also ilmenite plates (il) parallel to stage II schistosity folded with the schistosity by stage III crenulate folds. Plane-polarized light.

axial surfaces of generally open, consistently leíthanded folds that plunge gently to moderately to the north. Unfortunately, no data are available from immediately south of the Shelburne Falls dome (fig. 44 ), and the few available data from immediately south of the Goshen dome (fig. 44) are ambiguous. Thus, the direction of plunge of stage III folds on the south side of the domes cannot be determined. These folds deform both bedding and the stage II schistosity. Small stage III folds with amplitudes of a few centimetres to a few metres are common throughout the area, particularly in the more schistose rocks of the Goshen and uppermost Moretown Formations. Stage III folds sufficiently large to affect the outcrop pattern at 1:24,000 scale are restricted to the general vicinity of Blandford (fig. 44).

Stage III slip cleavage is well developed and appears to maintain a consistent orientation around the Goshen and Shelburne Falls domes, whereas stage II schistosity is deformed by the domes and wraps around them. In places near the Goshen dome, the stage III cleavage becomes a schistosity that obliterates the earlier stage II schistosity. This transition from slip cleavage to schistosity is very similar to the transition described by White (1949) from east-central Vermont. Thus, the rise of the domes was probably approximately synchronous with or slightly earlier than stage III.

\section{STAGE IV}

In the northwestern and west-central parts of the area, a slip cleavage and associated minor folds deform earlier structures and constitute stage IV deformation. These structures strike north and dip steeply to vertically. The axes of the folds are horizontal or gently plunging. The folds are tight to open, and, if all are interpreted as parasitic folds, they indicate that they are on the east limb of a major anticline. Thus, the orientation of these folds is similar to that of stage II folds, but they deform the stage II schistosity and are generally more open. Except in exposures where both slip cleavages are present, stage IV slip cleavage can be distinguished from stage III slip cleavage only by its orientation.

The pertinent features of the four stages of deformation are summarized in table 1. Representative minor folds of stages II, III, and IV are plotted in figure 48.

TABLE 1.-Summary of characteristics of the four stages of deformation

\begin{tabular}{|c|c|c|c|c|}
\hline Stage & I & II & III & IV \\
\hline $\begin{array}{l}\text { Axial-surface } \\
\text { foliation. }\end{array}$ & None recognized --- & Schistosity -- & Slip cleavage - & Slip cleavage. \\
\hline Fold style & Unknown ------- & Tight to isoclinal & Open & Open. \\
\hline Fold sense & $-\cdots---$ & None - - - & Left hand & $\begin{array}{l}\text { Satellitic on east limb of } \\
\text { major anticline. }\end{array}$ \\
\hline $\begin{array}{l}\text { Attitude of axial } \\
\text { surface. }\end{array}$ & East-west? -_. & North-south vertical _--- & Northeast dips northwest & North-south vertical. \\
\hline Attitude of axis - & Gentle (?) & $\begin{array}{l}\text { Steep in pre-Silurian, } \\
\text { horizontal in Silurian- } \\
\text { Devonian. }\end{array}$ & Moderate north & Horizontal. \\
\hline Fold amplitude -- & Small (?) & $\begin{array}{l}\text { Few centimetres in pre- } \\
\text { Silurian; thousands of } \\
\text { metres in Silurian and } \\
\text { Devonian. }\end{array}$ & $\begin{array}{l}\text { Few centimetres to few metres } \\
\text { except near Blandford. }\end{array}$ & $10 \pm \mathrm{cm}$ \\
\hline Age --.-- & Taconic(?) - - & Acadian & Acadian - & Acadian (?). \\
\hline
\end{tabular}




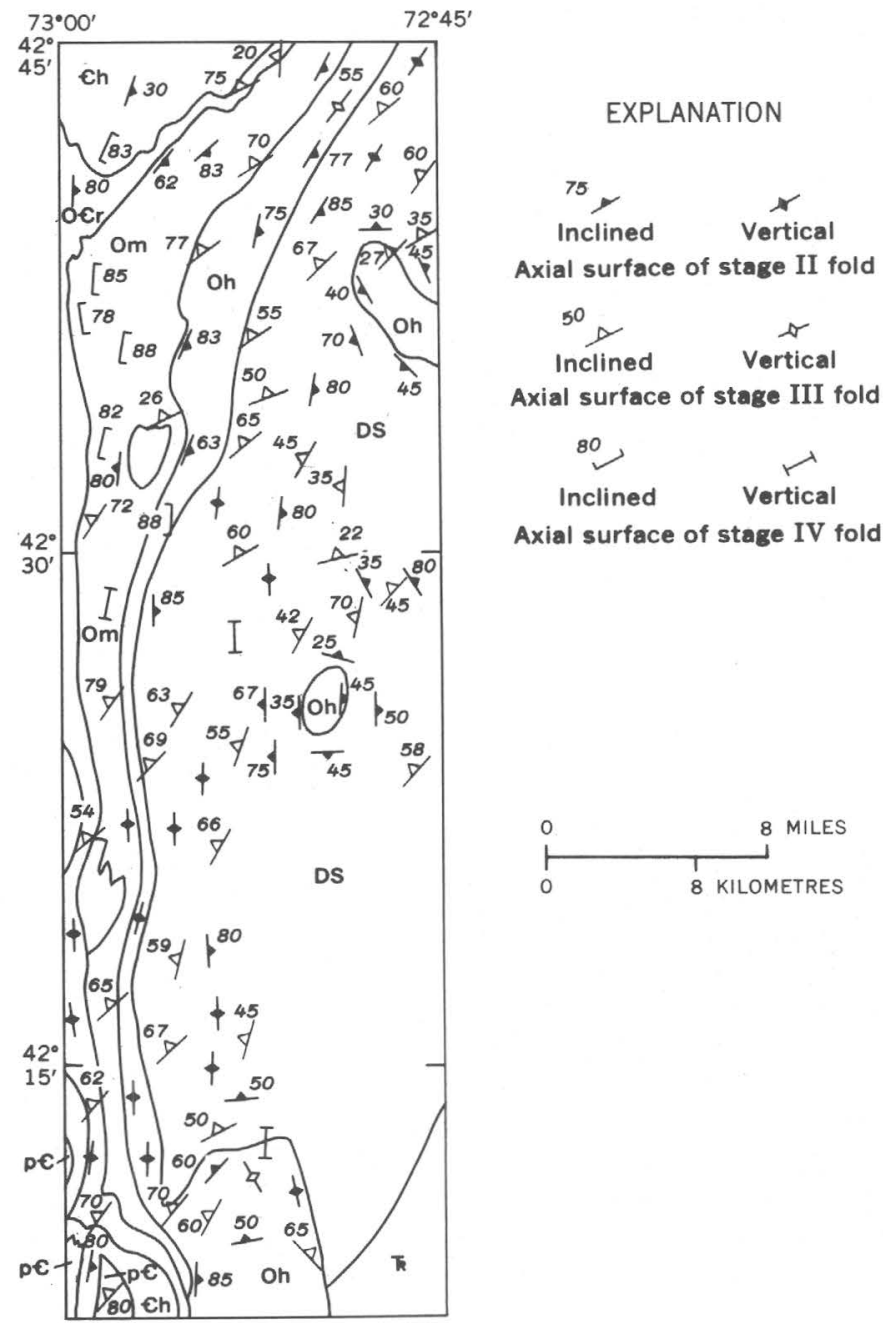

FIGURE 48.-Generalized geologic map of the study area showing orientation of axial surfaces of representative stage II, stage III, and stage IV minor folds. Map-unit boundaries and formation symbols same as in figure 44. Area with no symbols in southeast part of figure has been mapped by Stanley (1975) and S. F. Clark, Jr. (unpub. data, 1972).

\section{METAMORPHISM}

The Paleozoic geologic history of the area includes episodes of metamorphism which are related to the four stages of folding described above.

Metamorphic isograds indicating the first appearance of staurolite, kyanite, and sillimanite are shown on figure 44. The area of this report thus includes rocks regionally metamorphosed to the garnet, staurolite, and kyanite zones. Common mineral assemblages, with quartz and muscovite, in pelitic schists in these metamorphic zones are as follows:

Garnet zone

Garnet-biotite-chlorite

Staurolite zone

Garnet-biotite
Garnet-biotite-staurolite

Chlorite-biotite-staurolite

Chlorite-garnet-biotite-staurolite Kyanite zone

Staurolite-garnet-biotite

Staurolite-kyanite-biotite

Staurolite-kyanite-biotite-garnet

Kyanite-biotite

Kyanite-biotite-garnet

Kyanite-chlorite-biotite

Kyanite-chlorite-biotite-garnet

No metamorphic discontinuity analogous to the structural discontinuity between stages I and II has been recognized between Silurian and Ordovician rocks. Thus, I have recognized no retrograding of earlier relatively higher grade metamorphic minerals in the pre-Silurian rocks by later Acadian metamorphism. It is possible, however, that a relatively lower grade Taconic metamorphism affected the pre-Silurian rocks and that its effects are now obliterated by a relatively higher grade Acadian metamorphism.

The earliest metamorphism recognized in the area involved formation of quartz, muscovite, chlorite, carbonaceous material, biotite, and ilmenite parallel to and presumably synchronous with the stage II schistosity (figs. 45 and 49). The regional metamorphism reached at least biotite grade during the time of stage II deformation.

The biotite porphyroblasts in figure $49 B$ include streams of fine-grained matrix minerals that define stage II schistosity and therefore postdate the schistosity in figure $49 \mathrm{~A}$. Thus, we have evidence for two generations of biotite-one during and one later than stage II. The younger biotite forms conspicuously larger porphyroblasts of crossed biotite, oriented across the schistosity, in many of the pelitic rocks of the area. The porphyroblasts of chlorite in figure $49 \mathrm{~A}$ similarly indicate at least two generations of chlorite.

Figure 50 shows biotite porphyroblasts ripped up along their edges and crenulated by stage III. These biotite porphyroblasts, which appear to be the same age as those in figure $49 B$, are interpreted to have grown not only after stage II but before stage III.

In figure 51, quartz has grown in pressure shadows where stage III slip cleavage has intersected a garnet porphyroblast. The slip-cleavage planes are refracted around the garnet. Both relations suggest that the garnet also grew before or possibly during stage III. Thus, the metamorphism appears to have reached garnet grade before or during stage III. The age relations between stage II and garnet 


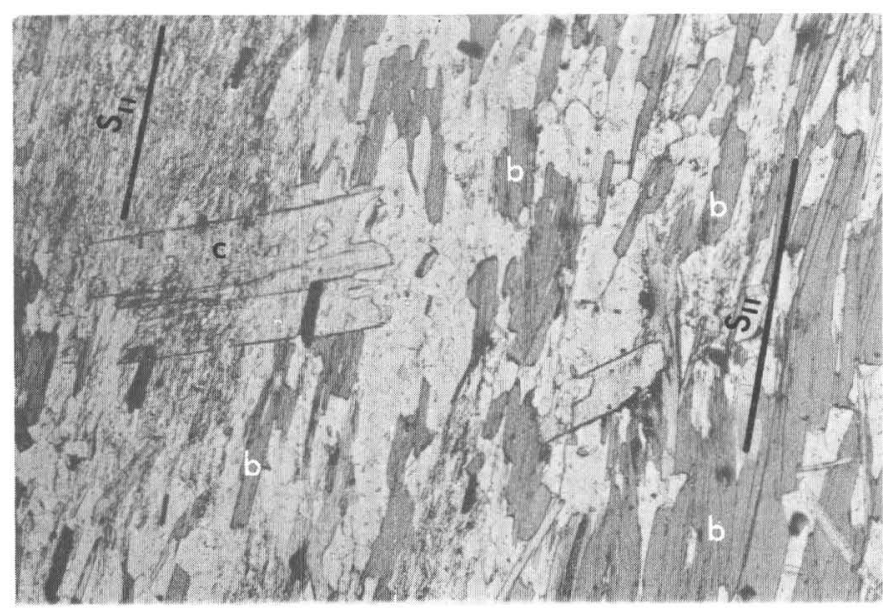

A

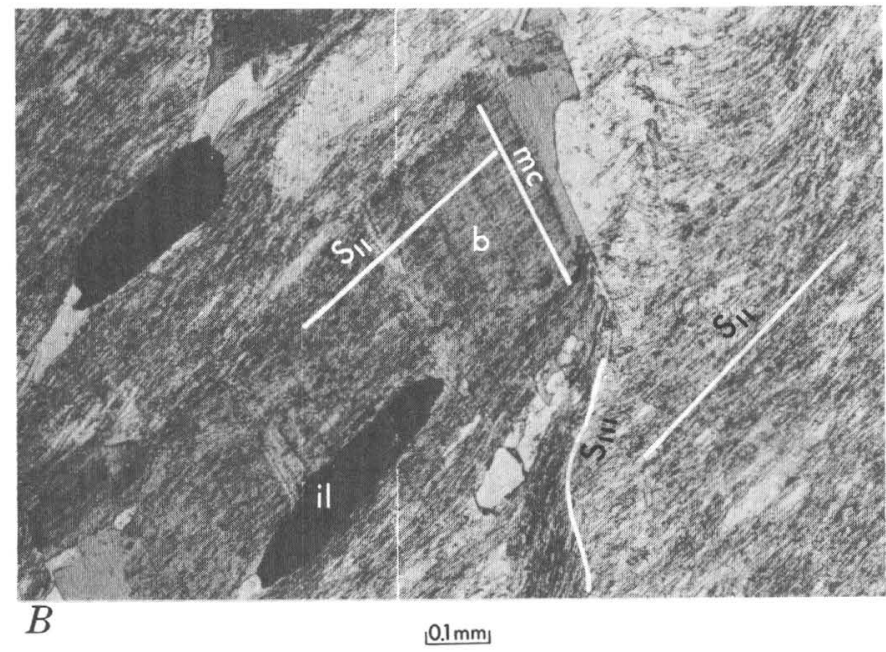

Figure 49.-Photomicrographs (plane-polarized light) showing mineral growth parallel to stage II schistosity $\left(\mathrm{S}_{\mathrm{II}}\right)$. $A$, Locality 3 , figure 44 . Well-oriented plates of biotite (b) in Moretown carbonaceous schist. Note post-stage II porphyroblast of chlorite (c) crosscutting schistosity. $B$, Locality 1 , figure 44 . Plates of ilmenite (il) parallel to stage II schistosity included within later porphyroblast of biotite (b) in Goshen carbonaceous schist. Lines in biotite porphyroblast are mineral cleavage $(\mathrm{mc})$.

growth are difficult to ascertain, but thin-section studies suggest that at least some garnet growth took place after formation of stage II schistosity.

Metamorphic mineral growth during stage III has not been recognized in most of the area. Thus, no porphyroblasts are in or parallel to the slip-cleavage planes shown in figure 47 or in the other photomicrographs. Mechanical reorientation of muscovite into stage III cleavage planes is common around the domes, and quartz rods are parallel to stage III fold axes in the area of large stage III folds west of Blandford (fig. 44). Stewart Clark (oral commun.,

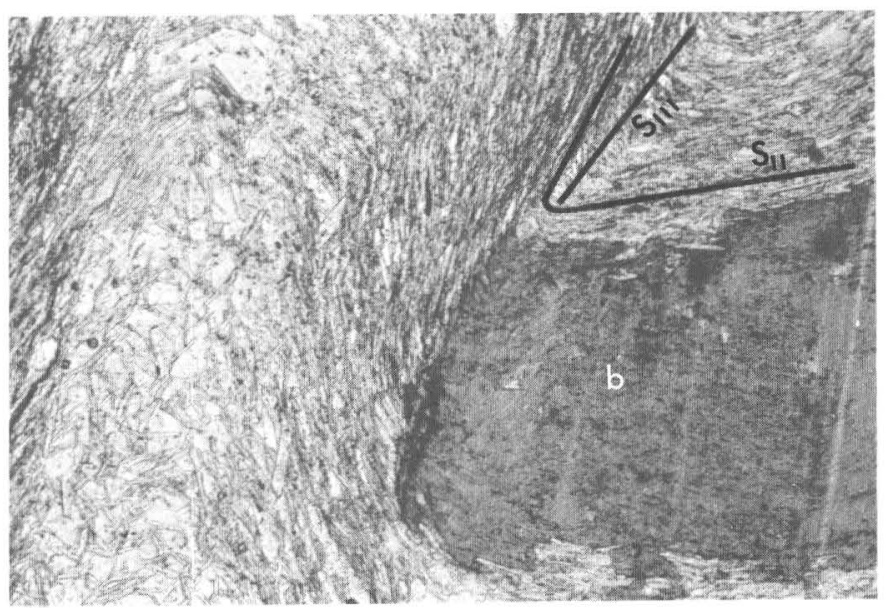

A

$0.1 \mathrm{~mm}$

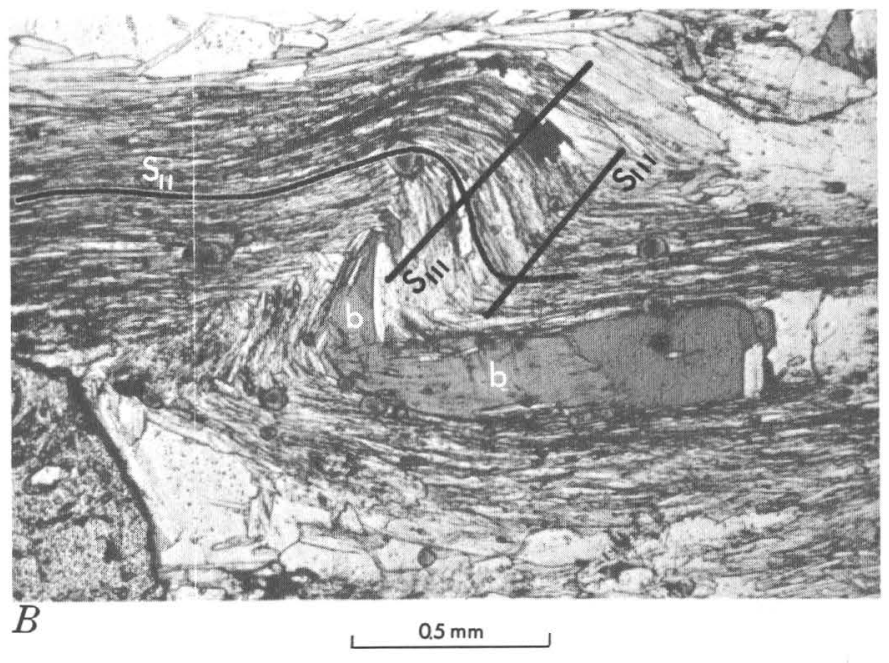

Figure 50.-Photomicrographs (plane-polarized light) of biotite porphyroblasts (b) in Goshen carbonaceous schists showing deformation of porphyroblasts by stage III $\left(\mathrm{S}_{\mathrm{III}}\right)$. Stage II schistosity is $\mathrm{S}_{11}$. $A$, Locality 2, figure 44. Slipcleavage plane shreds edge of porphyroblast. $B$, Locality 7 , figure 44. Stage III crenulate fold deforms porphyroblast into $L$ shape.

1970) reported orientation of some staurolite and kyanite porphyroblasts parallel to stage III fold axes east of Blandford; this occurrence is discussed later.

The major period of porphyroblast growth followed stage-III folding. Figure 52 shows a staurolite porphyroblast which includes trains of quartz, ilmenite, and carbonaceous material arranged parallel to stage II schistosity and deformed by stage III crenulate folds. Thus, the staurolite postdates stage III. Figure 53 portrays considerable geologic history in itself. In the lower part of the picture, a staurolite porphyroblast shows included fine-grained muscovite, graphite, and quartz that outline stage 


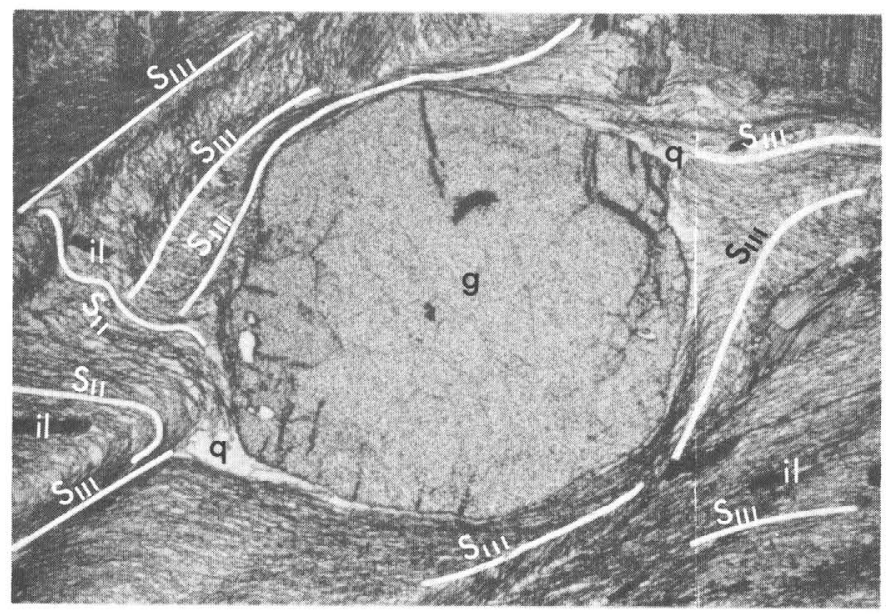

$1.0 \mathrm{~mm}$

FIGURE 51.-Photomicrograph of a garnet porphyroblast (g) in a Goshen carbonaceous schist showing quartz-filled strain shadows (q) where the porphyroblast is intersected by stage III slip-cleavage planes $\left(S_{I I I}\right)$. Note also plates of ilmenite (il) parallel to stage II schistosity $\left(\mathrm{S}_{\mathrm{II}}\right)$. Locality 2, figure 44. Plane-polarized light.

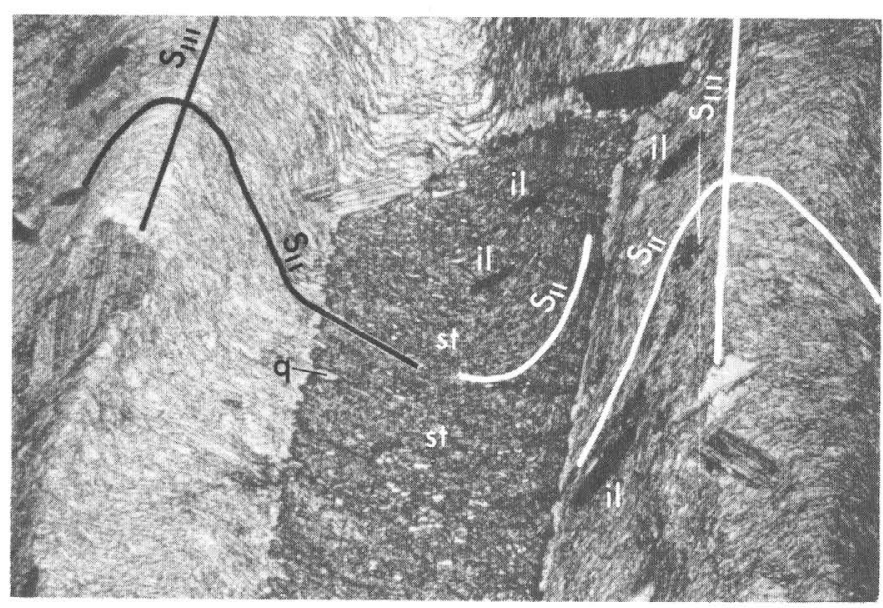

$1.0 \mathrm{~mm}$

FIGURE 52.-Photomicrograph of Goshen carbonaceous schist showing curved trains of quartz (q), carbonaceous particles, and ilmenite (il) parallel to stage II schistosity $\left(\mathrm{S}_{\mathrm{II}}\right)$, deformed by stage III slip cleavage $\left(\mathrm{S}_{\mathrm{III}}\right)$, included in a porphyroblast of staurolite (st). Locality 2, figure 44. Planepolarized light.

II schistosity and that are in turn deformed by stage III slip cleavage. The upper part of the staurolite has partly replaced a biotite porphyroblast which apparently was in existence and relatively inclusion free before development of the slip cleavage. The slip cleavage is partly deflected around the biotite. This part of the staurolite is inclusion free. The poikilitic and nonpoikilitic parts of the staurolite are optically continuous. The suggested history

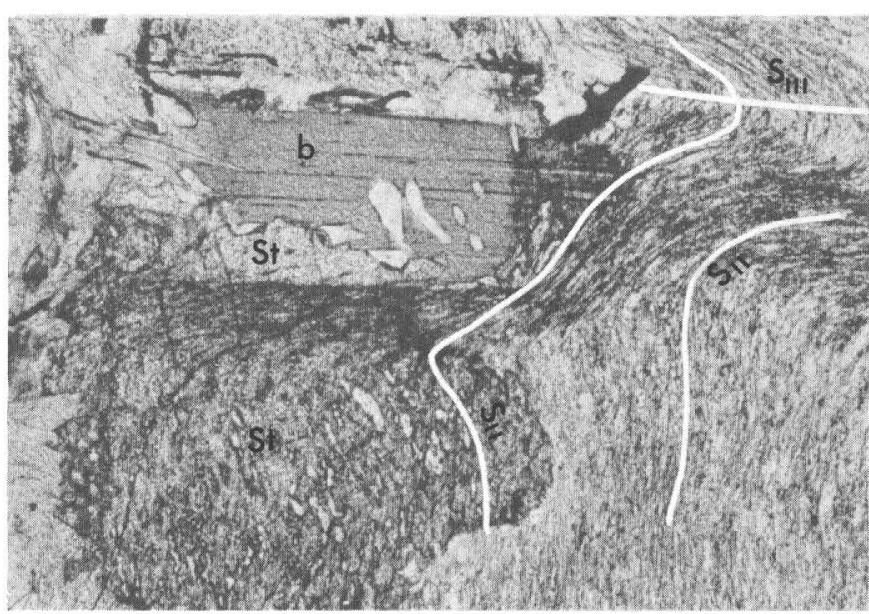

$0.1 \mathrm{~mm}$

FIGURE 53.-Photomicrograph of Goshen carbonaceous schist showing a porphyroblast of staurolite (st) replacing groundmass schist and part of a biotite porphyroblast (b). See text for discussion. Locality 2, figure 44. Plane-polarized light.

from this thin section is:

1. Formation of the stage II schistosity.

2. Growth of the biotite porphyroblast.

3. Formation of the stage III slip cleavage.

4. Growth of the staurolite porphyroblast, accompanied by some recrystallization of biotite.

In figure $54 A$, a twinned plagioclase porphyroblast includes trains of quartz and opaque grains that are parallel to stage II schistosity and are deformed by stage III crenulate folds. The fact that the twin planes are underformed clearly shows that the twinning formed after stage III crenulate folds.

In figure $54 B$, porphyroblasts of chlorite include deformed trains of carbonaceous flakes, indicating that their age is post-stage III and distinctly younger than the chlorite shown in figure $45 B$, which is parallel to and presumably coeval with stage II.

South of the kyanite isograd (fig. 44), abundant kyanite blades generally grow across and are undeformed by the crenulate folds of stage III. Thus, they postdate stage III. In some of the rocks east of Blandford (fig. 44), however, S. J. Clark, Jr., (oral commun., 1970) reported that kyanite blades locally are parallel or semiparallel to axes of probable stage III folds. Similar relations were seen at a few localities of Goshen rocks east of Chester, Mass. (fig. 44). If these folds are indeed stage III, the interpretation is that these kyanite crystals grew approximately concurrently with stage III.

From these relations, I have concluded that the regional metamorphism accompanying stage II pro- 

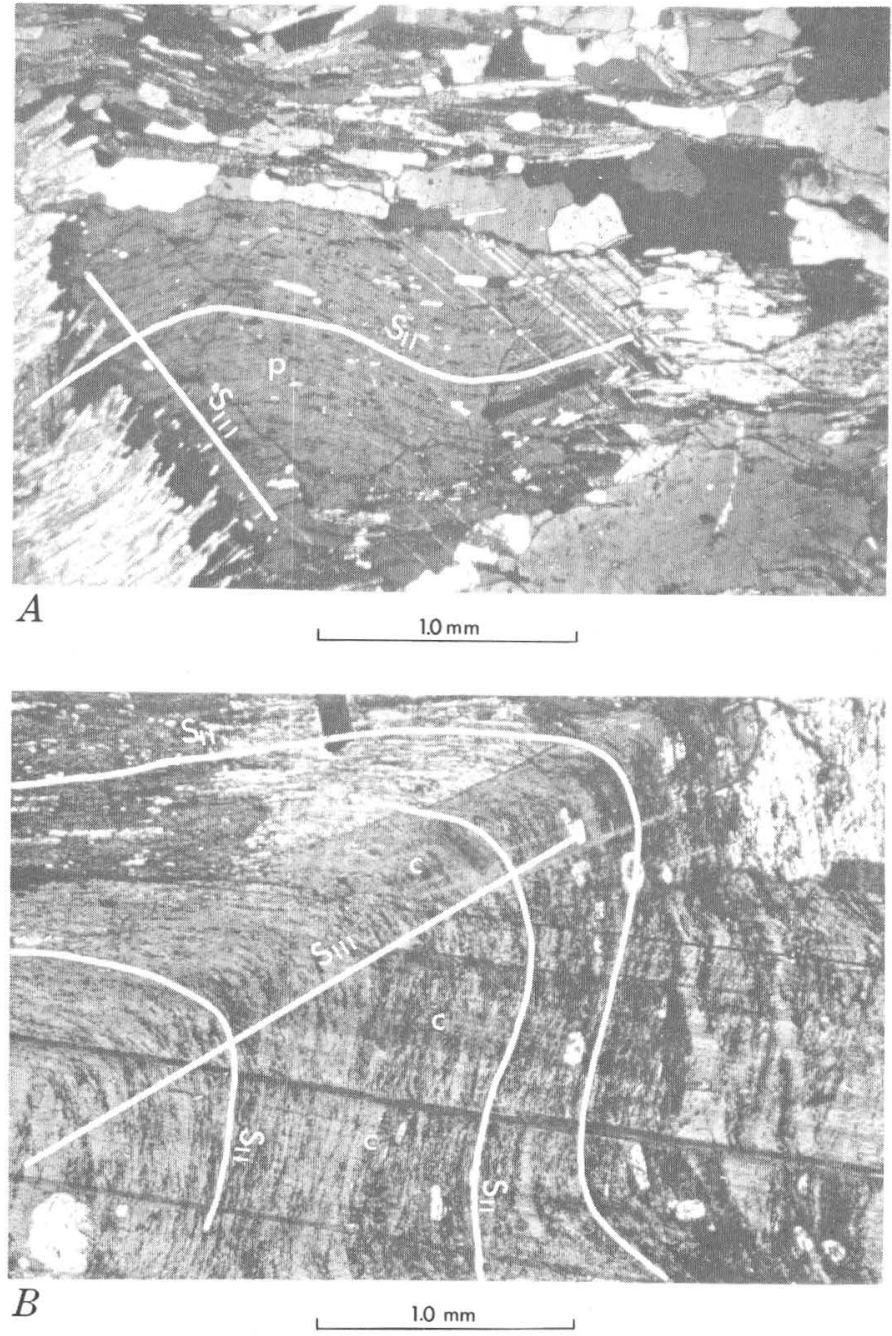

FIGURE 54.-Photomicrographs of Goshen schists showing porphyroblasts interpreted as younger than stage III. $A$, Locality 6, figure 44. Plagioclase porphyroblast (p) includes stage III crenulate folds $\left(\mathrm{S}_{\mathrm{III}}\right)$ that deform trains of carbonaceous flakes and quartz grains parallel to stage II schistosity $\left(\mathrm{S}_{\mathrm{II}}\right)$. Crossed polarizers. $B$, Locality 7 , figure 44 . Chlorite porphyroblasts (c) include stage III crenulate folds $\left(\mathrm{S}_{\mathrm{III}}\right)$ that deform trains of carbonaceous material parallel to stage II schistosity $\left(\mathrm{S}_{\mathrm{II}}\right)$. Plane-polarized light.

duced fine-grained muscovite, biotite, chlorite, and carbonaceous flakes, and larger ilmenite plates and quartz grains parallel to the stage II schistosity. After stage II but before stage III, garnet-grade metamorphism was reached, and porphyroblasts of biotite and garnet formed. Porphyroblasts of plagioclase and muscovite probably also grew at this time. After stage III, kyanite grade was reached in the southeast part of the area, and, in rocks of appropriate composition and grade, porphyroblasts of chlorite, staurolite, and kyanite grew. Preexisting porphyroblasts of plagioclase recrystallized into new optical orientation, and some new ones may have grown. Thus, there was a progressive increase in metamorphic grade southeastward across the area, transgressing the formation of stages II and III (fig. 55). The local rough parallelism of kyanite blades

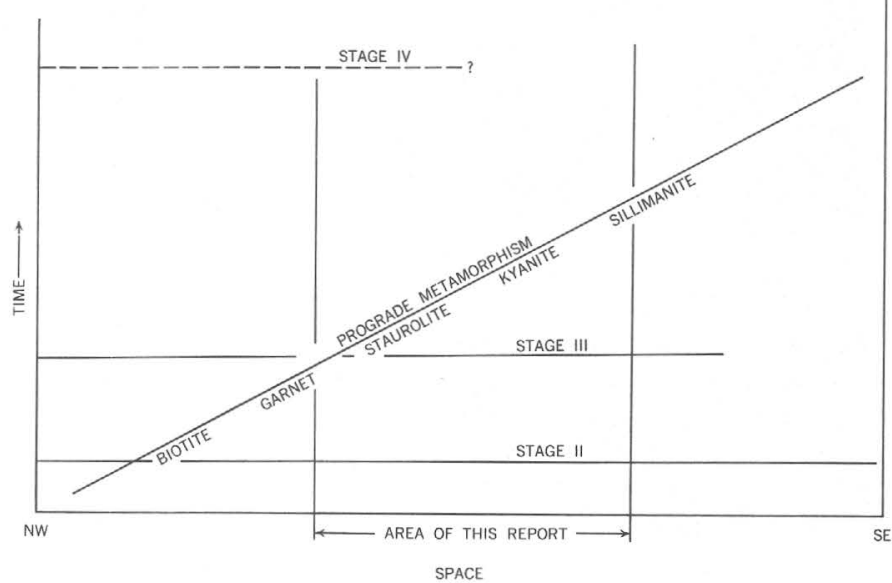

FIGURE 55.-Time and space relations between prograde regional metamorphism and stages of deformation during the Acadian orogeny.

with post-stage II fold axes in the southeast and south-central parts of the area suggests either local variations in the relative times of stage III and kyanite-grade metamorphism or that the late folds in these areas are folds of stage IV of Stanley (1975) that have been misidentified as stage III.

The near absence of staurolite and kyanite from pre-Silurian rocks north of Chester, Mass., in contrast to the abundance of these minerals in the Goshen Formation north of Chester has been noted by Hatch (1969) and Hatch, and others (1970). Because the growth of staurolite and kyanite postdated stage III, the apparent westward termination of the staurolite and kyanite isograds at the base of the Goshen clearly cannot result from stage II movement on the décollement at that boundary.

Stage IV apparently postdated the metamorphism, but the geographic restriction of positively identifiable stage IV folds to the west-central and northwest parts of the area where staurolite and kyanite porphyroblasts are not present in the rocks makes dating stage IV more tenuous. Stage IV may have accompanied the rise of the Berkshire massif.

\section{INTRUSIVE IGNEOUS EVENTS}

The small lenticular bodies of ultramafic rock shown in figure 44 are serpentinite and steatite, 
which are strongly foliated parallel to the regional stage II schistosity. Because they occur only in preSilurian rocks and bear the imprint of the stage II schistosity, they are considered to be pre-stage II and probably Ordovician in age.

The Middlefield Granite, immediately north of Chester village (fig. 44), is lithically similar to and correlated with the Kinsman Quartz Monzonite of the New Hampshire Plutonic Series of New Hampshire. Biotite from the Middlefield has been dated at about 360 m.y. by both $\mathrm{Rb}-\mathrm{Sr}$ and $\mathrm{K}-\mathrm{Ar}$ methods (R. E. Zartman, written communs., 1969, 1970). The rock has a distinct to weak foliation parallel to the stage II regional schistosity, suggesting that it was intruded just before or during stage II. If the age dates are primary-crystallization dates rather than metamorphic dates, this puts a minimum 360 m.y. or slightly younger age on stage II.

The eastern and southern parts of the area southeast of the kyanite isograd abound in small sills and dikes of two-mica Williamsburg-type granite and pegmatite, which northwest of the kyanite isograd are rare. These bodies, which are not shown on figure 44 because of their small size, are unfoliated and thus are believed to largely postdate stage II. They are nearly identical to granite and pegmatite of the New Hampshire Plutonic Series which are considered slightly younger than the Kinsman (Billings, 1956).

The restriction of the Williamsburg-type granite and pegmatite to the area southeast of the kyanite isograd suggests that the intrusion of the Williamsburg-type sills and the thermal maximum of the regional metamorphism are approximately coeval. The Williamsburg has been correlated with the binary granite and associated pegmatite of the New Hampshire Plutonic Series (Hatch and others, 1970) and thus assigned a late Early or possibly early Middle Devonian age. This sets a late Early or possibly early Middle Devonian age on the regional metamorphic maximum and thus a minimum age for stages II and III.

The age of stage IV is still somewhat equivocal because it cannot as yet be related with sufficient certainty to either the metamorphic or plutonic events.

\section{SUMMARY}

Table 2 summarizes the deformational, metamorphic, and intrusive igneous history of the area as it is now understood. The Taconic age for stage I is based on the fact that it folds Middle Ordovician rocks but apparently does not fold Middle Silurian and younger rocks. Stages II and III must be Acadian because they deform Lower Devor ian stratified rocks but predate upper Lower Devouian granites. Stage IV is inferred to be Acadian but could conceivably be younger.

The sequence of events described by Stanley (1975) corresponds exactly with that described in this chapter and thus suggests the same tectonic history from the northernmost part of Massachusetts south through much of the eastern part of western Connecticut.

TABLE 2.-Summary of geologic history

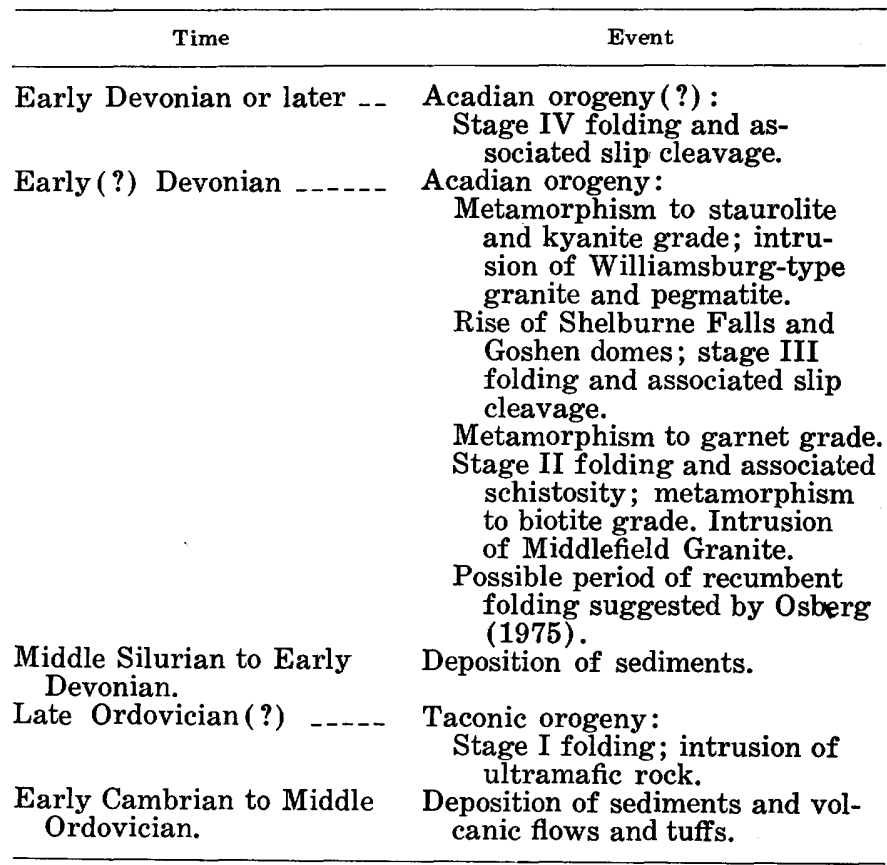

\section{ACKNOWLEDGMENTS}

The fieldwork for this chapter was done in cooperation with the Massachusetts Department of Public Works. Many other people have worked on the mapping of this area, including $\mathrm{A}$. H. Chidester, R. G. Clark, Jr., S. F. Clark, Jr., S. A. Norton, P. H. Osberg, and R. S. Stanley. Although this chapter takes advantage of their mapping, as well as many fruitful hours of discussion with them, they should not share in the blame for any shortcomings of what is said here. J. B. Epstein took the photomicrographs, and his discussion of them with me stimulated and encouraged some of the ideas presented here. The report has benefited from thoughtful reviews by D. S. Harwood, J. B. Epstein, L. R. Page, and S. A. Norton. 


\section{REFERENCES CITED}

Billings, M. P., 1956, The geology of New Hampshire, Part II, Bedrock geology: Concord, N. H., New Hampshire State Plan. Devel. Comm., 203 p.

Chidester, A. H., Hatch, N. L., Jr., Osberg, P. H., Norton, S. A., and Hartshorn, J. H., 1967, Geologic map of the Rowe quadrangle, Franklin and Berkshire Counties, Massachusetts, and Bennington and Windham Counties, Vermont: U.S. Geol. Survey Geol. Quad. Map GQ-642.

Hatch, N. L., Jr., 1968, Isoclinal folding indicated by primary sedimentary structures in western Massachusetts: U.S. Geol. Survey Prof. Paper 600-D, p. D108-D114.

1969, Geologic map of the Worthington quadrangle, Hampshire and Berkshire Counties, Massachusetts: U.S. Geol. Survey Geol. Quad. Map GQ-857.

1972, Tectonic history of part of the east limb of the Berkshire anticlinorium, Massachusetts [abs.]: Geol. Soc. America, Abs. with Programs, v. 4, no. 1, p. 19-20.

Hatch, N. L., Jr., Chidester, A. H., Osberg, P. H., and Norton, S. A., 1966, Redefinition of the Rowe Schist in northwestern Massachusetts, in .Cohee, G. V., and West, W. S., Changes in stratigraphic nomenclature by the U.S. Geollogical Survey, 1965: U.S. Geol. Survey Bull. 1244-A, p. A33-A35.

Hatch, N. L., Jr., and Hartshorn, J. H., 1968, Geologic map of the Heath quadrangle, Massachusetts-Vermont: U.S. Survey Geol. Quad. Map GQ-735.

Hatch, N. L., Jr., Norton, S. A., and Clark, R. G., Jr., 1970, Geologic map of the Chester quadrangle, Hampden and Hampshire Counties, Massachusetts: U.S. Geol. Survey Geol. Quad. Map GQ-858.

Hepburn, J. C., 1975, Tectonic and metamorphic chronology of the Devonian and Silurian rocks in the Guilford dome area, southeastern Vermont, in Tectonic studies of the Berkshire massif, western Massachusetts, Connecticut, and Vermont: U.S. Geol. Survey Prof. Paper 888-C, p. 33-49.

Norton, S. A., 1971, Possible thrust faults between Lower Cambrian and Precambrian rocks, east edge of the Berkshire highlands, western Massachusetts [abs.]: Geol. Soc. America, Abs. with Programs, v. 3, no. 1, p. 46.

- 1975, Chronology of Paleozoic tectonic and thermal metamorphic events in Ordovician, Cambrian, and Precambrian rocks at the north end of the Berkshire massif, in Tectonic studies of the Berkshire massif, western Massachusetts, Connecticut, and Vermont: U.S. Geol. Survey Prof. Paper 888-B, p. 21-31.

Osberg, P. H., 1972, Recumbent folding of the Goshen and Waits River Formations, western Massachusetts [abs.]: Geol. Soc. America, Abs. with Programs, v. 4, no. 1, p. 37-38.

1975, Recumbent folding of the Goshen and Waits River Formations, western Massachusetts, in Tectonic studies of the Berkshire massif, western Massachusetts, Connecticut, and Vermont: U.S. Geol. Survey Prof. Paper 888-E, p. $63-68$.

Osberg, P. H., Hatch, N. L., Jr., and Norton, S. A., 1971, Geologic map of the Plainfield quadrangle, Franklin, Hampshire, and Berkshire Counties, Massachusetts: U.S. Geol. Survey Geol. Quad. Map GQ-877.

Ratcliffe, N. M. and Harwood, D. S., 1975, Blastomylonites associated with recumbent folds and overthrusts at the western edge of the Berkshire massif, Connecticut and Massachusetts, in Tectonic studies of the Berkshire massif, western Massachusetts, Connecticut, and Vermont: U.S. Geol. Survey Prof. Paper 888-A, p. 1-19.

Stanley, R. S., 1967, Geometry and age relations of some minor folds and their relation to the Woronoco nappe, Blandford and Woronoco quadrangles, in New England Intercoll. Geol. Conf., 59th Ann. Mtg., Oct. 13-15, 1967, Guidebook for field trips in the Connecticut Valley of Massachusetts: p. $48-60$.

1975, Time and space relationships of structures associated with the domes of southwestern Massachusetts and western Connecticut, in Tectonic studies of the Berkshire massif, western Massachusetts, Connecticut, and Vermont: U.S. Geol. Survey Prof. Paper 888-F, p. 69-96.

White, W. S., 1949, Cleavage in east-central Vermont: Am. Geophys. Union Trans., v. 30, no. 4, p. 587-594. 


\title{
Recumbent Folding of the Goshen and Waits River Formations, Western Massachusetts
}

\author{
By PHILIP H. OSBERG
}

TECTONIC STUDIES OF THE BERKSHIRE MASSIF, WESTERN MASSACHUSETTS, CONNECTICUT, AND VERMONT

GEOLOGICAL SURVEY PROFESSIONAL PAPER $888-\mathrm{E}$

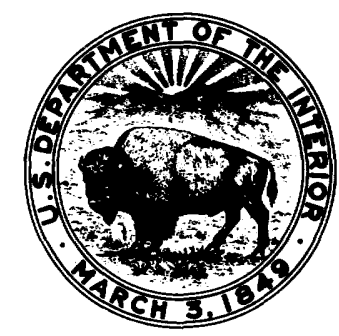




\section{CONTENTS}

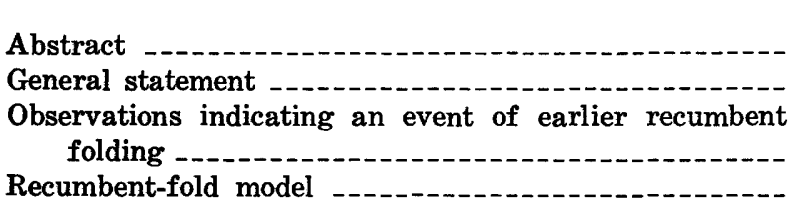

\begin{tabular}{r|l}
$\begin{array}{r}\text { Page } \\
63 \\
63\end{array}$ & Regional considerations \\
& Age of deformation \\
63 & Acknowledgments \\
65 & References cited
\end{tabular}

\section{ILLUSTRATIONS}

FIGURE 56. Regional geologic map showing interrelationships between recumbent folds, domes, and $F_{2}$ folding, western Massachusetts

57. Sketch map of isoclinal $F_{2}$ fold in Deerfield River, south of Heath, Mass

58. Sketch showing isoclinal $\mathbf{F}_{2}$ fold at Cummington, Mass

59. Model for surface deformed by recumbent folding followed by upright isoclinal folding -

60. Sketch map of the Heath quadrangle and northern edge of the Ashfield quadrangle

61. Cartographic expression of fold-depression and recumbent-fold models 


\author{
TECTONIC STUDIES OF THE BERKSHIRE MASSIF, WESTERN MASSACHUSETTS, \\ CONNECTICUT, AND VERMONT
}

\title{
RECUMBENT FOLDING OF THE GOSHEN AND WAITS RIVER FORMATIONS, WESTERN MASSACHUSETTS
}

\author{
By Philip H. Osberg ${ }^{1}$
}

\begin{abstract}
Locally in the Goshen Formation beds are inverted at the hinges of mesoscopic isoclinal upright folds, and in other places the beds at the hinges of these folds are right-side up. Meager evidence of this sort and one observation of mesoscopic recumbent folds suggest that an event of recumbent folding predated the development of the isoclinal upright folding.

The crenulated wedge-shaped outcrop pattern of Waits River Formation mapped in the Heath quadrangle is reinterpreted as the core of an east-facing recumbent fold; the crenulated aspect of the outcrop pattern is due to the superposition of isoclinal upright folds on the recumbent fold. Minor structural relationships indicate that in this wedge-shaped outcrop the northern boundary of the Waits River Formation is right-side up, whereas the southern boundary is inverted. Both limbs of the recumbent fold are inclined to the south. The Shelburne Falls dome is diapiric and cuts both limbs of the recumbent fold, exposing the pre-Goshen rocks in its core.
\end{abstract}

\section{GENERAL STATEMENT}

Mapping in the Goshen and Waits River Formations in western Massachusetts has established, on the basis of intersecting minor structural features, three well recorded deformational events: $F_{2}$ and $F_{3}$ (stage II and stage III of Hatch, 1975) followed by the emplacement of diapiric domes. $F_{2}$ is manifest, over much of the outcrop of the Goshen and Waits River Formations, as large and small isoclinal upright folds that have been thought to represent the earliest deformational event in these rocks. $F_{3}$ does not generally affect the gross geometry of earlier folds in the studied region and consequently will not be considered further.

This chapter presents the case of an event of recumbent folding predating the $F_{2}$ in the Goshen and Waits River Formations. Although the evidence

\footnotetext{
1 University of Maine, Orono, Maine.
}

for such folding is meager, the relationship between the sequencing of beds and the direction of closure of $F_{2}$ at a few ouecrops is best interpreted in terms of an earlier event of recumbent folding; this interpretation is strengthened by a single observation of mesoscopic recumbent folds in the Goshen Formation. Because of a paucity of definitive data, a regional interpretation based on a recumbent-fold model has been only partly successful.

\section{OBSERVATIONS INDICATING AN EVENT OF EARLIER RECUMBENT FOLDING}

Observations indicating an event of earlier recumbent folding are: (1) the existence of recumbent folds cut by $\mathrm{F}_{2}$ cleavage and (2) the relationship between the sequencing of beds and the direction of closure of $\mathrm{F}_{2}$.

Isoclinal recumbent folds in the Goshen Formation are well exposed $8.6 \mathrm{~km}(5.4$ miles $) \mathrm{S} .53^{\circ} \mathrm{E}$. from Heath (fig. 56). Bedding can be traced through several recumbent folds, the amplitudes of which are measured in tens of metres. Their axial surfaces are oriented N. $12^{\circ}$ E., $21^{\circ} \mathrm{NW}$., and at this locality near Heath they plunge approximately $10^{\circ}-15^{\circ}$ northward. Both limbs of the recumbent folds are cut by well developed cleavage oriented N. $5^{\circ}$ W., $65^{\circ} \mathrm{SW}$. Because the cleavage is not deflected as it passes through both limbs of the recumbent folds, it is considered younger. The orientation of the cleavage is parallel to the axial surfaces of nearby folds that are interpreted to belong to $F_{2}$ on the basis of their isoclinal style, their axial-surface schistosity, and their orientation being compatible with $F_{2}$ throughout the region. These relationships indicate that $F_{2}$ is younger than the recumbent folds. 


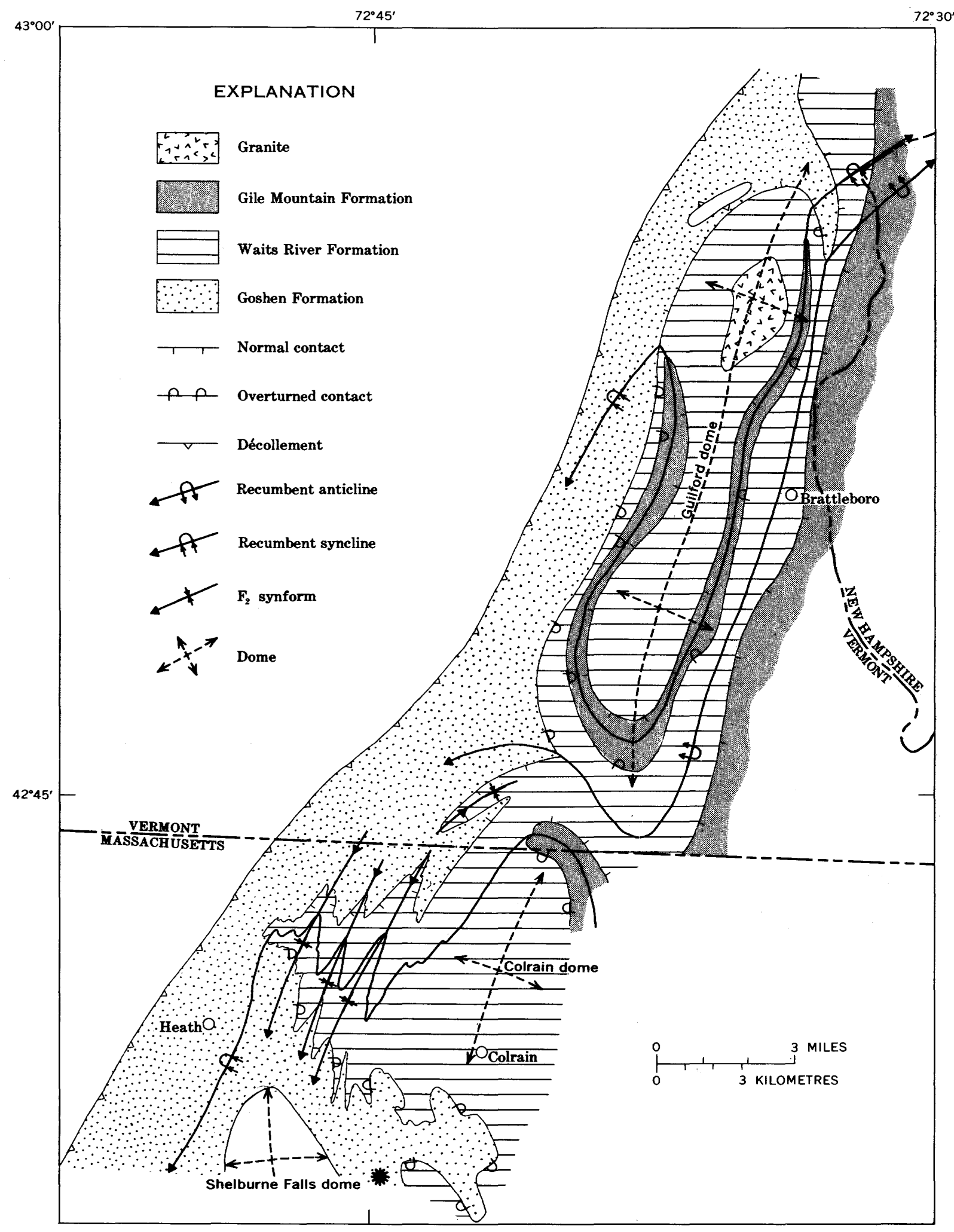

FIG JRE 56.-Regional geologic map showing interrelationships between recumbent folds, domes, and $F_{2}$ folding, western Massachusetts and adjacent Vermont. Cogwheel symbol indicates locality of mesoscopic recumbent folds 
Observations of graded beds and directions of closure of mesoscopic $F_{2}$ indicate that beds were inverted locally before $F_{2}$ deformation and, therefore, that an episode of deformation preceded $F_{2}$. The best exposure of these relationships is in the Deerfield River $5.9 \mathrm{~km}$ (3.7 miles) south of Heath (fig. 56). The sketch map of this exposure in figure 57 shows an isoclinal, upright synform, the orienta-

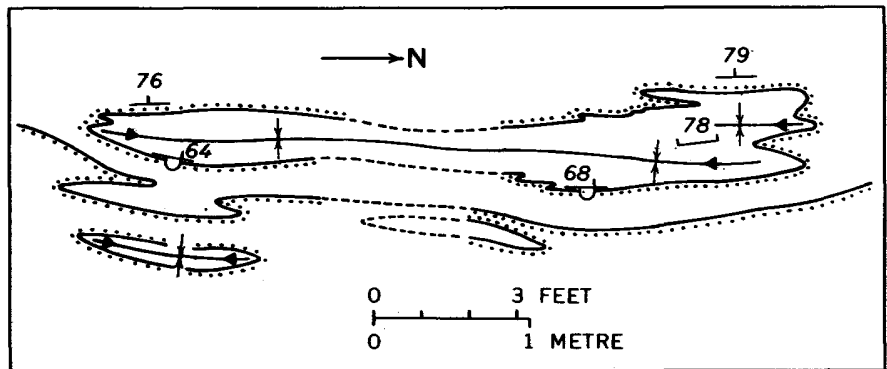

EXPLANATION

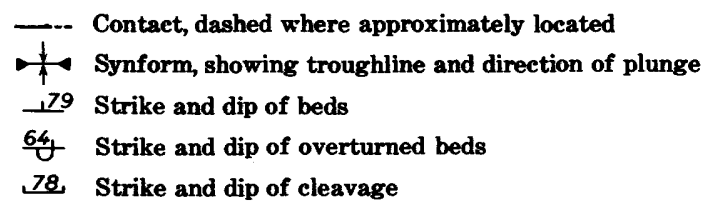

FIGURE 57.-Sketch map of isoclinal $F_{2}$ fold in the Deerfield River $5.9 \mathrm{~km}$ ( 3.7 miles) south of Heath, Mass. Stippling indicates bottom of graded beds.

tion of which is consistent with $F_{2}$. The beds dip $65^{\circ} \mathrm{W}$. in the east limb and $70^{\circ}-80^{\circ} \mathrm{W}$. in the west limb. A well-developed schistosity parallels the axial surface. The stippling in figure 57 represents the coarser parts of the beds. These graded beds, instead of indicating that younger rocks are in the core of the synform, indicate that older rocks are in the core. Thus the synform is an upside-down anticline and the beds here were upside down at the time of the isoclinal folding.

In contradiction to the above observations, at some exposure the graded beds and direction of closure of $F_{2}$ indicate that the beds were rightside up at the time of $F_{2}$ folding. Figure 58 is a sketch of a road cut at Cummington, Mass. The beds are deformed by a large isoclinal upright anticline belonging to $F_{2}$. The beds in the east limb dip $61^{\circ} \mathrm{SE}$., and the beds in the west limb dip $80^{\circ} \mathrm{SE}$. Graded beds shown by the stippling at the base of beds in the sketch indicate that older rocks are exposed in the core of the anticline. This outcrop shows no evidence of a deformation preceding $\mathrm{F}_{2}$.

\section{RECUMBENT-FOLD MODEL}

Observations like those cited above suggest the existence of recumbent folds that predate $\mathrm{F}_{2}$ folding.

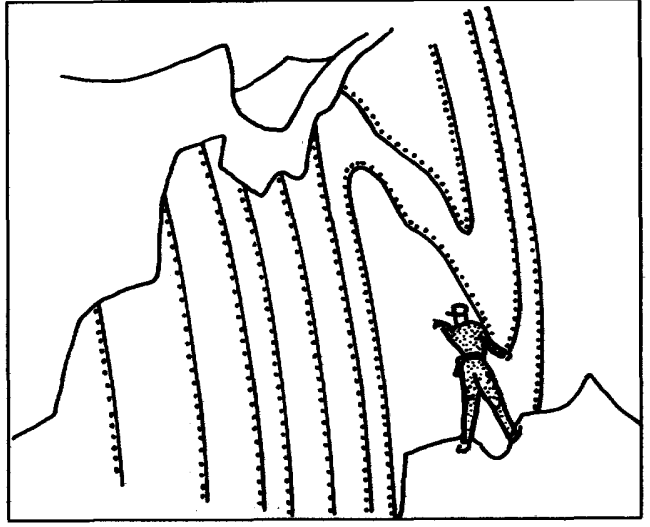

Figure 58.-Isoclinal $F_{2}$ fold at Cummington, Mass. Stippling indicates bottom of graded beds. Drawn from a photograph.

The proposed relationships are indicated schematically in figure 59. The surface shown in figure $59 \mathrm{~A}$ is the boundary, for example, between the Goshen and the Waits River Formations, the Waits River Formation being inside the fold. Subsequent to the development of the recumbent fold, both limbs were folded by isoclinal upright folds of $\mathrm{F}_{2}$; the superposition of $\mathrm{F}_{2}$ on the earlier recumbent folding is shown in figure $59 \mathrm{~B}$. Observations in the Goshen Formation in the vicinity of (1) (fig. 59B) would be similar to those at Cummington (fig. 58), whereas observations near (2) would approximate these in the Deerfield River (fig. 57). Needless to say, the resulting interaction is complex and masks the earlier event except at random localities.

\section{REGIONAL CONSIDERATIONS}

Hatch (Hatch and Hartshorn, 1968) has mapped a crudely wedge-shaped outcrop of Waits River Formation in the Heath quadrangle (fig. 60). Its apex is in the north-central part of the quadrangle, and the wedge enlarges eastward. The boundary is irregularly sutured. This wedge-shaped outcrop of Waits River Formation is here postulated to be the core of a southeast-plunging recumbent fold that opens toward the east.

Although the general wedge shape of the outcrop of the Waits River Formation is consistent with a southeast-plunging, east-facing recumbent fold, the details of the crenulatious characteristic of the contact between the Goshen and Waits River Formations are not. The map pattern of Hatch is based on a model of a fold depression, and the sinusoids at the north and south boundaries of the Waits River have consequently been drawn out of phase (fig. $61 A$ ). If the recumbent model is correct, the sinusoids should be drawn in phase (fig. $61 B$ ). Whether or not the 

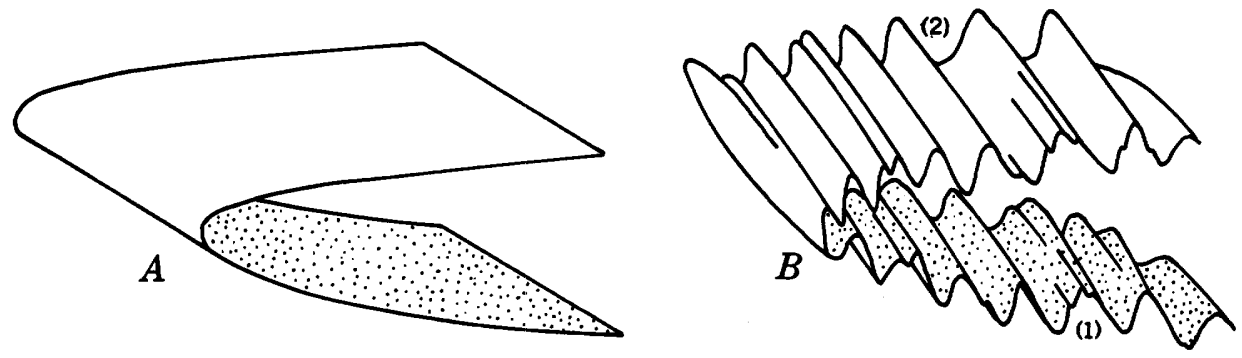

FIGURE 59.-Model for surface deformed by recumbent folding $(A)$ followed by upright isoclinal folding $(B)$. Stippling indicates bottom of folded surface. Compare (1) to exposure in figure 58 and (2) to figure 57.

pattern of exposures on which the published cartography is based would allow modifications to accommodate the recumbent-fold model was not ascertained.

Attempts to substantiate the recumbent-fold model using observations of minor structural features met with only partial success, mostly because of the paucity of definitive observations. Structural observations were made of: (1) the directions of the plunges of $\mathrm{F}_{2}$ and (2) the relationships between the topping directions of beds and the direction of closure of $\mathrm{F}_{2}$

The plunges of observed $F_{2}$ folds are plotted in figure 60. On both the southern and northern boundaries of the Waits River Formation the majority of the plunges are to the south. Such relationships are consistent with the recumbent-fold model but not with the fold-depression model. The horizontal plunges of the folds north of the outcrop of the Waits River Formation and the north plunge near the center of the Waits River Formation are thought to be due to minor culminations and depressions in the $F_{2}$ axes. The horizontal axis northeast of the Shelburne Falls dome is thought to have been rotated from a south-plunging orientation by the upwarping accompanying doming.

Topping directions, as determined by the relationships between graded beds and the direction of closure of $\mathrm{F}_{2}$ folds, are also indicated in figure 60. The graded character of the beds is clear at only five localities and, consequently, definitive information is severely limited. Where information about the plunge of $\mathrm{F}_{2}$ is evident but no indication of topping direction exists, either the beds are ungraded or the

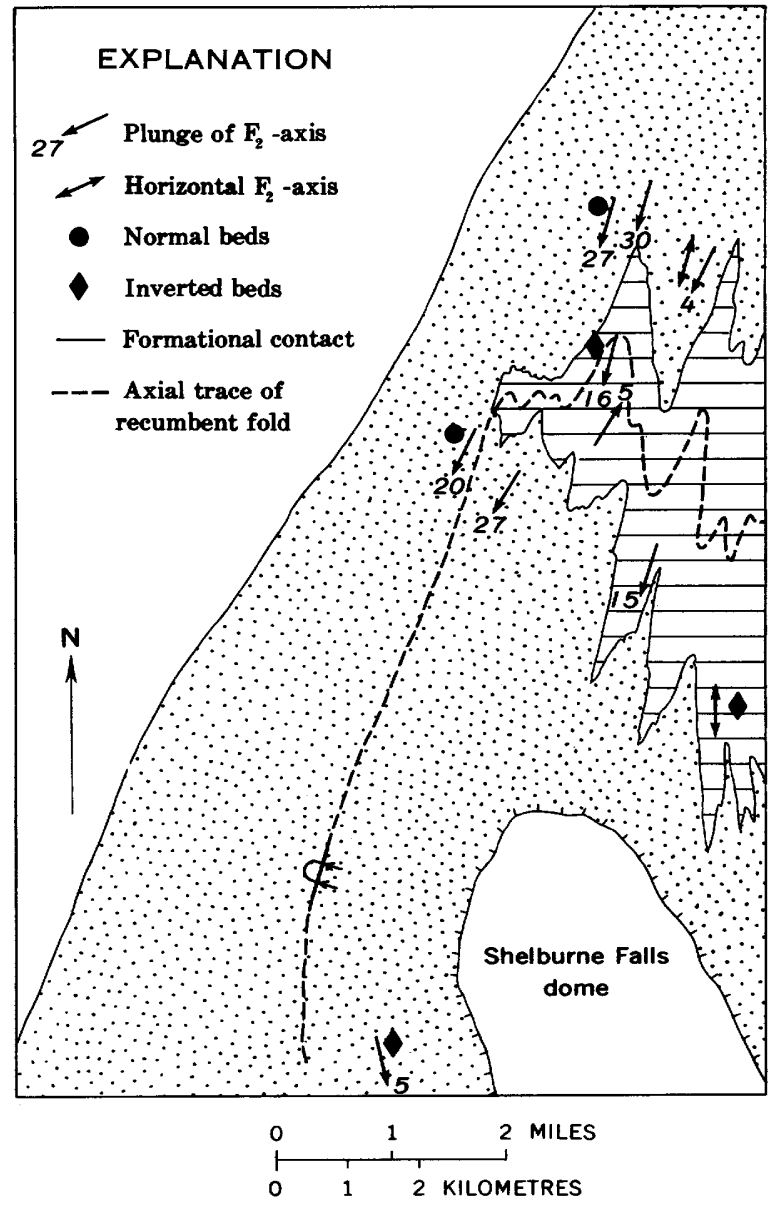

FIGURE 60.-Sketch map of the Heath quadrangle and northern edge of the Ashfield quadrangle. Stippled pattern, Goshen Formation; horizontal ruling, Waits River Formation. 


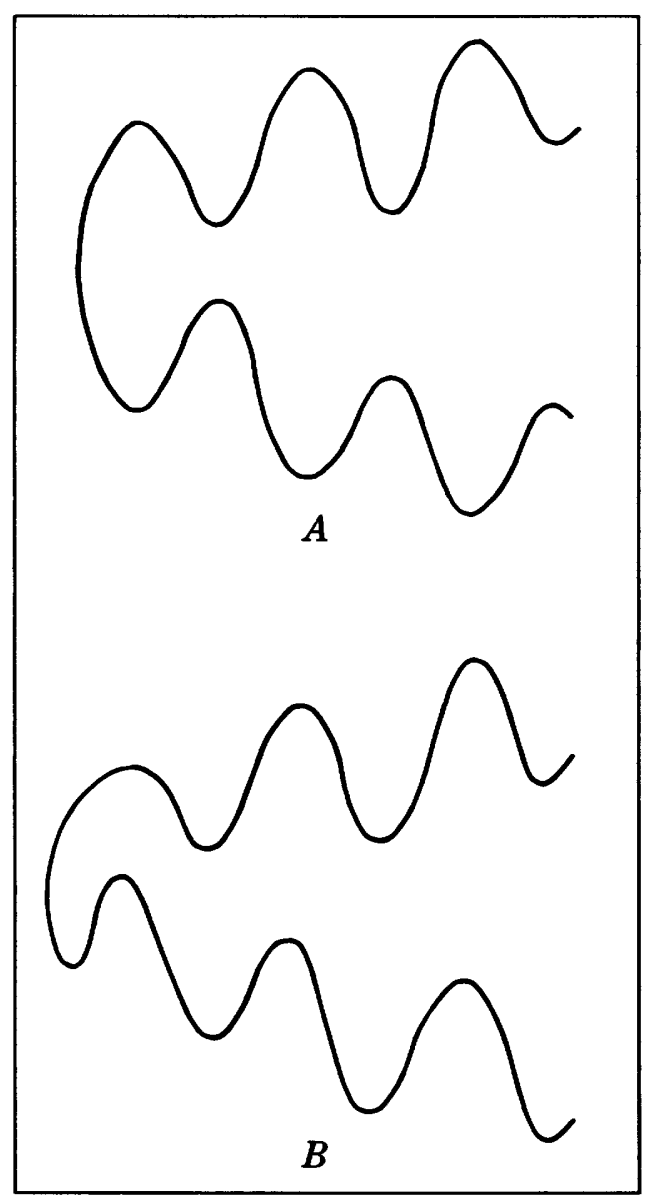

Figure 61.-Cartographic expression of $(A)$ fold-depression model and $(B)$ recumbentfold model.

graded character is equivocal. These limited data are consistent with a south-plunging recumbent fold.

A regional geologic map has been compiled from the Heath (Hatch and Hartshorn, 1968), the Colrain (Segerstrom, 1956), and the Brattleboro (Hepburn, 1972) quadrangles (fig. 56). The contacts between the Goshen Formation and pre-Goshen rocks, between the Waits River and Goshen Formations, and between the Gile Mountain and Waits River Formations are indicated. Heavy arrows indicate the axial traces of recumbent folds; all are inferred to be east-facing. A lowermost recumbent syncline is exposed owing to the diapiric action of the Guilford dome (Hepburn, 1975). The axis of this fold plunges southwestward off of the west flank of the dome and northeastward off of its east flank. A higher, much more poorly defined recumbent anticline is also draped around the south and east flanks of the Guilford dome. The plunge of the recumbent anticline is interpreted to be to the southwest and northeast off of the Guilford dome and is nearly parallel to the plunge of the underlying recumbent syncline. The recumbent syncline proposed in this paper is thought to be at a still higher level than the recumbent anticline and probably plunges southward at low angles. Its axial trace is controlled by the Colrain dome to the east and is folded by $F_{2}$ to the west. The Shelburne Falls dome has breached both of its limbs and exposes pre-Goshen rocks in its core.

The contact between the Goshen Formation and the pre-Goshen rocks is relatively straight and does not reflect the recumbent folding in the Goshen and Waits River Formations. Apparently, the lower part of the Goshen Formation has acted as a layer of compensation, taking up the difference in strain behavior between the Goshen Formation and the preGoshen rocks. Evidence of detachment along this line is not conclusive but cannot be ruled out on the basis of the information at hand.

\section{AGE OF DEFORMATION}

The recumbent folding described in this paper is best dated as Devonian and Silurian and, therefore, increases by one the Devonian and Silurian episodes of deformation described by Hatch (1975). The recumbent folding involves the Gile Mountain Formation, which is dated as probable Early Devonian, although its facies relations to the Goshen Formation do not rule out a Late Silurian age for at least part of the Gile Mountain Formation (Berry and Boucot, 1970 , p. 154). $F_{2}$ postdates the recumbent folding and is itself cut by the Williamsburg Granodiorite (Willard, 1956) which has not been dated but is compositionally similar to the Barre granite in Vermont; the Adamant pluton of Barre Granite has been dated by the K-Ar method as 349 m.y. (Faul, and others, 1963, p. 9). This date is assumed to represent the date of intrusion because the contact aureole of the Adamant pluton is well developed (Cady, 1956). Consequently, the time brackets surrounding the age of recumbent folding are Late Devonian to Late Silurian.

\section{ACKNOWLEDGMENTS}

This paper was critically reviewed by D. S. Harwood and N. L. Hatch, Jr.; the writer is appreciative of their many helpful comments and suggestions.

\section{REFERENCES CITED}

Berry, W. B. N., and Boucot, A. J., eds., 1970, Correlation of the North American Silurian rocks: Geol. Soc. America Spec. Paper 102, 289 p.

Cady, W. M., 1956, Bedrock geolo ry of the Montpelier quadrangle, Vermont: U.S. Geol. Survey Geol. Quad. Map GQ-79. 
Faul, Henry, Stern, T. W., Thomas, H. H., and Elmore, P. L. D., 1963, Ages of intrusion and metamorphism in the northern Appalachians: Am. Jour. Sci., v. 261, p. 1-19.

Hatch, N. L., Jr., 1975, Tectonic, metamorphic, and intrusive history of part of the east side of the Berkshire massif, Massachusetts, in Tectonic studies of the Berkshire massif, Western Massachusetts, Connecticut, and Vermont: U.S. Geol. Survey Prof. Paper 888-D, p. 51-62.

Hatch, N. L., Jr., and Hartshorn, J. H., 1968, Geologic map of the Heath quadrangle, Massachusetts-Vermont: U.S. Geol. Survey Geol. Quad. Map GQ-735.

Hepburn, J. C., 1972, Geology of the metamorphosed Paleozoic rocks in the Brattleboro area, Vermont: unpub. $\mathrm{Ph}$. D. thesis, Harvard University, $377 \mathrm{p}$.

- 1975, Tectonic and metamorphic chronology of the Devonian and Silurian rocks in the Guilford dome area, southeastern Vermont, in Tectonic studies of the Berkshire massif, western Massachusetts, Connecticut, and Vermont: U.S. Geol. Survey Prof. Paper 888-C, p. 33-49.

Segerstrom, Kenneth, 1956, Bedrock geology of the Colrain quadrangle, Massachusetts-Vermont: U.S. Geol. Survey Geol. Quad. Map GQ-86.

Willard, M. E., 1956, Bedrock geology of the Williamsburg quadrangle, Massachusetts: U.S. Geol. Survey Geol. Quad. Map GQ-85. 


\section{Time and Space Relationships of Structures Associated with the Domes of Southwestern Massachusetts and Western Connecticut}

By ROLFE S. STANLEY

TECTONIC STUDIES OF THE BERKSHIRE MASSIF, WESTERN MASSACHUSETTS, CONNEGTICUT, AND VERMONT

GEOLOGICAL SUR VEY PROFESSIONAL PAPER 888 - F

Prepared in cooperation with the

Commonwealth of Massachusetts

Department of Public Works

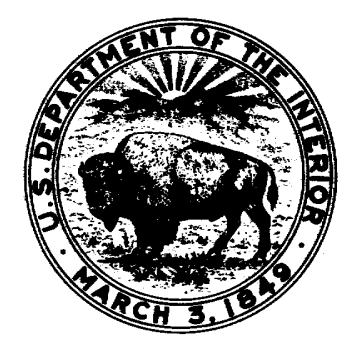





\section{CONTENTS}

\begin{abstract}
Introduction -..-.

Location and general geology

Method of analysis

Terminology

Blandford-Woronoco area, southwestern Massachusetts

Fold-generation characteristics

Axial-surface maps

Summary

Structural evolution
\end{abstract}

\begin{tabular}{r|r} 
Page & \\
69 & Collinsville quadrangle, western Connecticut \\
69 & Axial-surface maps \\
69 & Structural evolution \\
70 & Newton quadrangle, western Connecticut \\
73 & Axial-surface maps \\
75 & Structural evolution \\
75 & Regional correlation \\
76 & Acknowledgments \\
79 & References cited
\end{tabular}

\section{ILLUSTRATIONS}

FIGURE 62. Index map of southwestern Massachusetts and western Connecticut showing location of study areas and general geology of the region

63. Geologic map of the Blandford-Woronoco area showing axial surfaces of $F_{2}$ folds

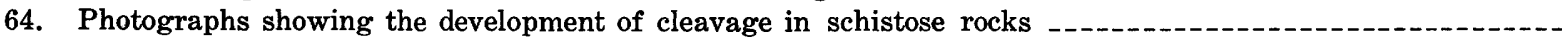

65. Photographs showing minor folds of $F_{1}$ through $F_{4}$, Cobble Mountain Reservoir

66. Lower hemisphere equal-area projections of poles to $F_{2}$ axial surfaces and $F_{2}$ fold axes within the Blandford-Woronoco area

67. Geologic map of the Blandford-Woronoco area showing axial surfaces of $F_{3}$ folds

68. Lower hemisphere equal-area projections of poles to $F_{3}$ axial surfaces and $F_{3}$ fold axes within the Blandford-Woronoco area

69. Geologic map of the Blandford-Woronoco area showing axial surfaces of $F_{4}$ folds

70. Lower hemisphere equal-area projections of poles to $F_{4}$ axial surfaces and $F_{4}$ fold axes within the Blandford-Woronoco area

71. Diagrams showing structural evolution of the Blandford-Woronoco area

72. Profile section of the Collinsville area with the effects of Triassic faulting subtracted

73-76. Geologic maps of :

73. Collinsville quadrangle showing axial surfaces of $F_{2}$ folds

74. Collinsville quadrangle showing axial surfaces of $\mathrm{F}_{3}$ folds

75. Newtown quadrangle showing axial surfaces of $F_{2}$ folds

76. Newtown quadrangle showing axial surfaces of $F_{3}($ ?) folds

77. Lower hemisphere equal-area projections of fold axes of $F_{2}$ and $F_{3}($ ?) in the Newtown quadrangle

78. Correlation chart of fold generations from western Massachusetts and western Connecticut

79. Generalized geologic map of southwestern Massachusetts and western Connecticut showing the axial surfaces of $F_{2}, F_{3}$, and $F_{4}$

\section{TABLES}

TABLE 1. Stratigraphic correlation chart

2. Characteristics of minor fold generations -

3. Orientation data for equal-area projections in Figures 66, 68, and 70 



\author{
TECTONIC STUDIES OF THE BERKSHIRE MASSIF, WESTERN MASSACHUSETTS, \\ CONNECTICUT, AND VERMONT
}

\title{
TIME AND SPACE RELATIONSHIPS OF STRUCTURES ASSOCIATED WITH THE DOMES OF SOUTHWESTERN MASSACHUSETTS AND WESTERN CONNECTICUT
}

\author{
By Rolfe S. Stanley ${ }^{1}$
}

\begin{abstract}
Four generations of minor folds have been related to the major folds associated with the Granville dome in the eugeosynclinal rocks of middle and early Paleozoic age east of the Berkshire anticlinorium in southwestern Massachusetts. This fold sequence has been tentatively correlated with structural sequences in western Massachusetts and western Connecticut.

The first generation of minor folds, which developed during the Taconic orogeny, lacks an axial-surface schistosity and is observed only in the rocks of pre-Silurian age. Major folds associated with this generation have not been recognized in the Blandford-Woronoco area in southwestern Massachusetts, but are present in the Newtown area in southwestern Connecticut.

The remaining three generations of minor folds, presumably developed during the Acadian orogeny, are present in rocks above and below the unconformity separating the Ordovician and Cambian rocks from the Devonian and Silurian rocks. The second generation has a penetrative schistosity that is parallel to the axial surfaces of east-facing isoclinal folds and nappes in the Ordovician and Cambrian rocks north and west of the Granville dome in western Massachusetts, the Collinsville and Bristol domes in western Connecticut, and in the Newtown area of southwestern Connecticut. This schistosity is also parallel to the synclinal nappes of Straits Schist (Devonian? and Silurian?) in and around the gneiss domes of western Connecticut. The axial surfaces of the isoclinal folds in the Goshen Formation of Devonian and Silurian age in western Massachusetts appear to belong to the second generation.

The third generation, commonly marked by a slip cleavage, is well developed around and between the gneiss domes of western Connecticut. Although the synclinal nappes of the Devonian and Silurian in western Connecticut developed during the second generation, their east-facing character at least north of the Granville dome was formed primarily during the third generation, when the felsic volcanic rocks of the Middle Ordovician rose as domes, redeforming the older isoclinal folds whose axial surfaces must have dipped steeply west, if we assume the domes rose vertically.

The fourth generation of folds deforms the slip cleavage of the third into a series of open antiforms and synforms north of the Granville domes. These folds appear to be the result of east-west compression.

\footnotetext{
${ }^{1}$ University of Vermont, Burlington, Vt.
}

\section{INTRODUCTION}

This chapter presents the results of structural studies on minor folds from western Connecticut (Collinsville quadrangle, Stanley, 1964, 1968; Newtown quadrangle, Stanley, unpub. data, 1970) and southwestern Massachusetts (Blandford and Woronoco quadrangles, Stanley, 1967, 1968, 1972) (see fig. 62). The objectives have been: (1) to develop reliable criteria for separating superposed folds into separate structural events (fold generations) which could be recognized with confidence from place to place; (2) to develop a coherent structural history for each area by relating minor fold generations to major structures mapped on a scale of $1: 24,000$; (3) to correlate the detailed structural histories for each of these separate areas; and (4) to link these results to structural events known to exist elsewhere in western New England.

\section{LOCATION AND GENERAL GEOLOGY}

The location and general geologic settings of the three study areas are shown in figure 62. These areas contain kyanite- or sillimanite-grade rocks that are stratigraphically equivalent to rocks of Early Devonian through Cambrian age of eastern Vermont.

The generalized structure in the eastern eugeosynclinal part of western Connecticut consists of a series of east-facing isoclinal folds or nappes that have been severely redeformed by the upward movement of lighter felsic volcanic material which now forms the core of elongate domes (figs. 62 and 79). North of the Blandford-Woronoco area the gneiss domes became less prominent and isoclinal folds with steeply inclined axial surfaces are abundant in the Devonian and Silurian rocks (Hatch, 1968, 1975).
\end{abstract}




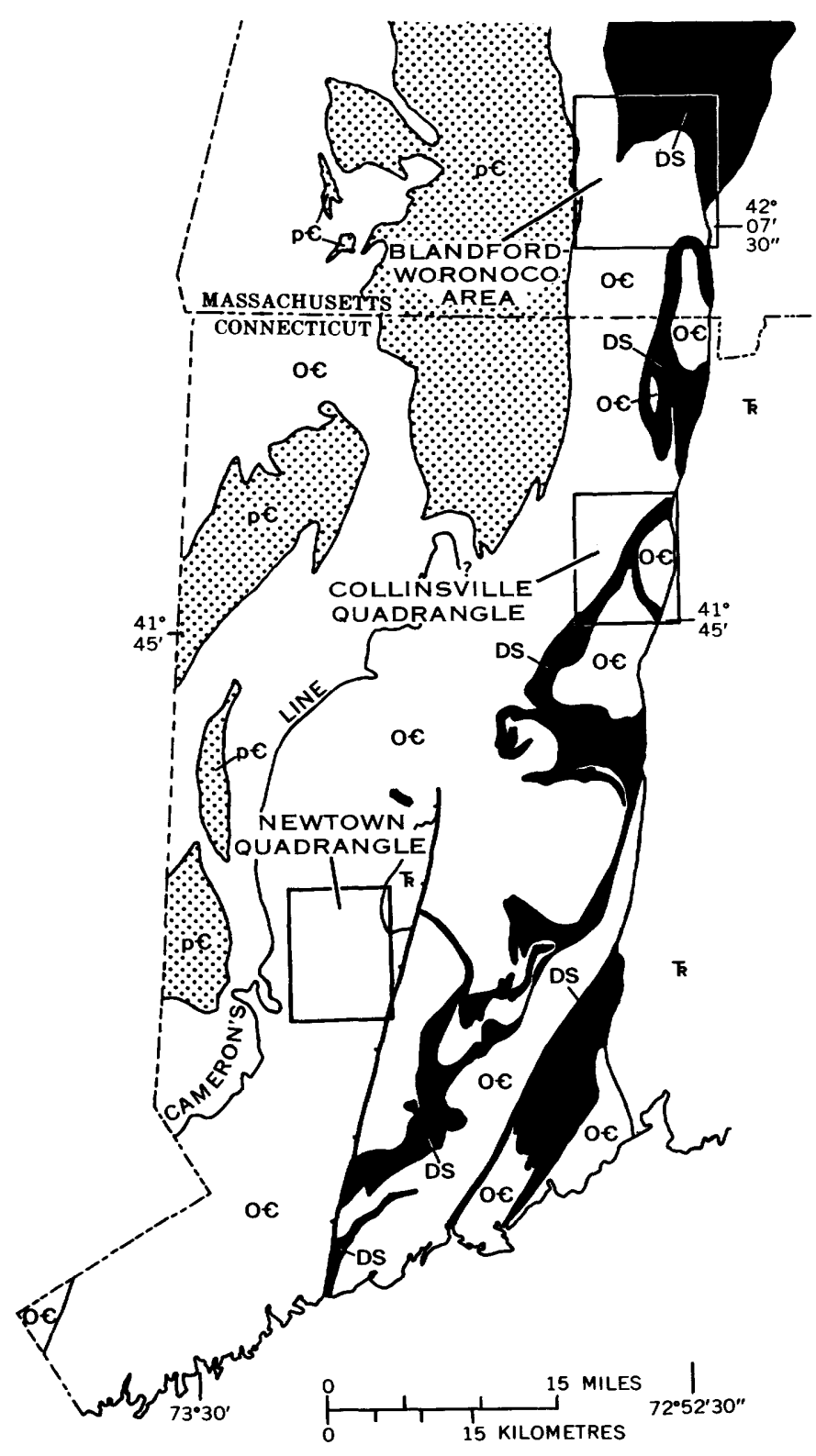

Figure 62.-Index map of southwestern Massachusetts and western Connecticut showing locations of study areas and the distribution of major areas of Triassic rocks ( $\pi$ ), Devonian and Silurian rocks (DS), Ordovician and Cambrian rocks (OC), and Precambrian rocks ( $P €$ ). Cameron's line separates the carbonate rocks to the west from the pelitic and volcanic rocks to the east.

\section{METHOD OF ANALYSIS}

Within any one area of contiguous outcrop, the age sequence of minor folds was based on the principle of superposition-a fold was considered younger if it deformed the axial surface and, in some localities, the axes of an older set or sets of folds. After the age sequence was established in well-exposed localities, the style, orientation, and intensity of deformation for each fold generation were documented for each rock type. Data on the attitude of hinge and axial surface were recorded for a number of folds of each generation so as to evaluate the overall consistency, or lack thereof, in orientation. Although quantitative measures of strain and deformation were not used in this work, qualitative estimates were based on fold tightness and cleavage development; the latter criterion proved to be the most meaningful parameter of deformation intensity throughout the areas of study. Most of my work was centered in the Cobble Mountain Formation (see table 1, fig. 63) in the Blandford-Woronoco area, because this area contains the most complete and best preserved sequence of superposed folds. Descriptive parameters are summarized in table 2.

Correlation of minor folds between localities of extensive outcrop within a quadrangle was based on relative age, style, and orientation. Although the form of the axial-surface cleavage proved to be the most reliable characteristic of each fold generation, no single criterion was consistently dependable. The criteria in table 2 are most successfully employed where the distance between outcrops is small; they become less reliable where the distance is 16 or $24 \mathrm{~km}$ ( 10 or 15 miles), at which scale orientation is usually of little value, and style and relative age are useful but only with considerable caution. Any scheme of regional correlation must be evaluated by the density and aereal distribution of reliable data on superposition. Because the data on superposed folds are sparce in some intervening quadrangles, any proposed correlation of the study areas in western Massachusetts and Connecticut is open to question. Correlation of structural events among the three major areas of this chapter is therefore based on the geological age of the rocks in which a given fold generation is developed and on the geometric relationship between minor and major folds. If, regarding the latter parameter, the statistical axial surface of a given generation of minor folds is parallel to the calculated axial surface of a major fold, then the two are considered coeval. Regional correlation of major structures mean that their associated minor folds are correlative in a structural sense. Using these methods, I have been able to assign and correlate approximately 2,000 minor folds to their proper fold generation within and among the three areas in western Massachusetts and Connecticut.

Field data on each minor fold generation were 
TABLE 1.-Stratigraphic correlation chart

\begin{tabular}{|c|c|c|c|c|c|c|c|c|}
\hline $\begin{array}{l}\text { E్ } \\
\text { कूّ } \\
\text { के }\end{array}$ & 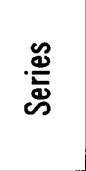 & \multicolumn{3}{|c|}{$\begin{array}{c}\text { Blandford-Woronoco } \\
\text { quadrangle } \\
\text { from Hatch and Stanley } \\
(1970,1974)\end{array}$} & \multicolumn{2}{|c|}{$\begin{array}{c}\text { Collinsville quadrangle } \\
\text { from Hatch } \\
\text { and Stanley } \\
(1970,1974)\end{array}$} & \multicolumn{2}{|c|}{$\begin{array}{l}\text { Newtown quadrangle } \\
\text { from Stanley } \\
\text { (unpub. data, } \\
1974 \text { ) }\end{array}$} \\
\hline 产. & - & \multicolumn{3}{|c|}{ Goshen Formation (DSg) } & \multicolumn{2}{|c|}{ Straits Schist (DSg) } & & \\
\hline 离 & $\frac{\frac{0}{\overline{0}}}{\frac{0}{2}}$ & \multicolumn{3}{|c|}{ Russell Mountain Formation } & \multicolumn{2}{|c|}{$\begin{array}{c}\text { Calc-silicate } \\
\text { quartzite lenses }\end{array}$} & & \\
\hline \multirow[t]{3}{*}{.동 } & \multirow[t]{2}{*}{ 흘 } & 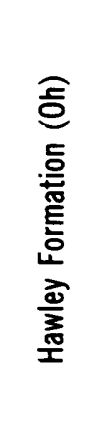 & 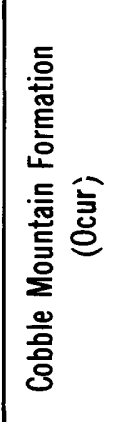 & 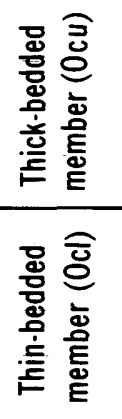 & 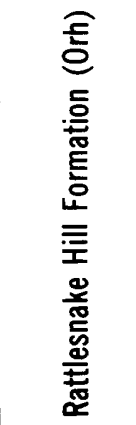 & 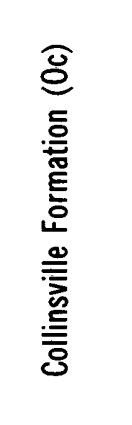 & & \\
\hline & & \multicolumn{3}{|c|}{ Moretown Formation $(0 \mathrm{~m})$} & $\begin{array}{l}\text { Satan's } \\
\text { Kingdom } \\
\text { Formation }\end{array}$ & $\begin{array}{c}\text { Taine } \\
\text { Mountain } \\
\text { Formation } \\
(0 \mathrm{tm})\end{array}$ & $\begin{array}{l}\text { Hartland } \\
\text { Formation- } \\
\text { Unit I } \\
\text { (Oh I) }\end{array}$ & \multirow{3}{*}{ 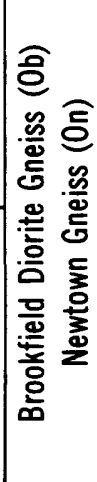 } \\
\hline & 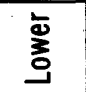 & \multirow{2}{*}{\multicolumn{3}{|c|}{ Rowe Schist $(0 € r$ ) }} & \multicolumn{2}{|c|}{ (0sk) } & \multirow{2}{*}{$\begin{array}{l}\text { Hartland } \\
\text { Formation- } \\
\text { Unit II } \\
(0 € \mathrm{Ch} \text { II and } \\
\left.0 € \mathrm{Ch} \|_{f}\right)\end{array}$} & \\
\hline \multirow[t]{2}{*}{ 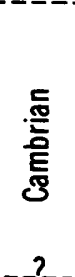 } & \multirow{2}{*}{ 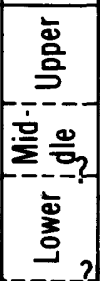 } & & & & \multicolumn{2}{|c|}{$\begin{array}{l}\text { Slashers Ledges } \\
\text { Formation } \\
(0 € s l)\end{array}$} & & \\
\hline & & \multicolumn{3}{|c|}{ Hoosac Formation (€h) } & & & & \\
\hline
\end{tabular}

analyzed in spherical projection and on geologic maps. Equal-area nets of fold hinges and poles to axial surfaces were prepared for subareas within each area. Subareas were delineated on the basis of the pattern of axial-surface poles which formed either diffuse point maxima or fairly complete greatcircle girdles (figs. 66, 68, 70, 77). Geologic maps showing axial surfaces of minor folds were prepared for each fold generation. Axial surfaces were used instead of fold axes because: (1) they proved to be the most reliable age criterion; (2) they provide a qualitative estimate of the intensity of deformation; (3) they record the presence of younger fold generations because they are essentially planar before they are subsequently deformed; and (4) they represent a principal symmetry plane of strain. This last statement is based on the theoretical work of Dieterich (1969) and Osberg $(1971,1975)$ which shows that the axial-surface cleavage represents a principal plane of finite strain. This plane is normal to $\lambda_{3}$, the axis of minimum quadratic elongation, or $\varepsilon_{1}$, the axis of maximum principal compressive strain. Because folding has been largely passive in the schistose rocks, which comprise much of the stratigraphic section in western Massachusetts and Connecticut, the geometric axial surface of folds lacking cleavage can be taken as a fair representation of this principal plane of strain. 




FIgURE 63.-Geologic map of the Blandford-Woronoco area showing axial surfaces of $F_{2}$ folds. Stratigraphic units and symbols are listed in table 1 ; also, micaceous quartzite in the Goshen Formation (DSgq), rusty schist and gneiss in the upper part of the Cobble Mountain Formation (Ocur), and Precambrian rocks (p€). Heavy curved line marks axial surface of Woronoco fold, outlined by the contact between Ocl and Ocu. Letters A through F and numbers 1 and 2 are discussed in text. 
TABLE 2.-Characteristics of minor fold generations

\begin{tabular}{|c|c|c|c|c|}
\hline \multirow{2}{*}{ Characteristics } & \multicolumn{4}{|c|}{ Fold generation } \\
\hline & $F_{1}$ & $F_{2}$ & $F_{3}$ & $F_{4}$ \\
\hline Profile form -.- & Tight to isoclinal_- & $\begin{array}{l}\text { Isoclinal, similar, } \\
\text { concentric. }\end{array}$ & $\begin{array}{l}\text { Similar in schist with a } \\
\text { crenulate to chevron pro- } \\
\text { file; mostly concentric } \\
\text { and open in gneiss and } \\
\text { granulite; box-shaped, } \\
\text { concentric, similar, } \\
\text { chevron in amphibolite. }\end{array}$ & $\begin{array}{l}\text { Crenulate in schist and } \\
\text { therefore identical to } \\
\mathrm{F}_{3} \text {. In most places repre- } \\
\text { sented by broad undula- } \\
\text { tions of axial surfaces } \\
\text { of } \mathrm{F}_{3} \text {. }\end{array}$ \\
\hline Hinge extent -- & Unknown --- - - - & Long, straight _... & $\begin{array}{l}\text { Short and slightly irreg- } \\
\text { ular, hinges tend to be } \\
\text { en echelon. }\end{array}$ & Same as $F_{3}$. \\
\hline Limbs _-.--- & $\begin{array}{l}\text { Curved, deformed } \\
\text { by } \mathrm{F}_{2}, \mathrm{~F}_{3}, \mathrm{~F}_{4} \text {. }\end{array}$ & $\begin{array}{l}\text { Curved, deformed by } \\
\qquad F_{3}, F_{4} .\end{array}$ & $\begin{array}{l}\text { Planar in schist to gently } \\
\text { curved in gneiss, granu- } \\
\text { lite. }\end{array}$ & Same as $\mathrm{F}_{3}$. \\
\hline $\begin{array}{l}\text { Axial-surface } \\
\text { cleavage. }\end{array}$ & $\begin{array}{l}\text { None, remnant pre- } \\
\text { served in some } \\
\text { places. }\end{array}$ & $\begin{array}{l}\text { An excellent schistosity } \\
\text { formed by micas ori- } \\
\text { ented parallel to axial } \\
\text { surface of fold. Spacing } \\
\text { between schistose layers } \\
\text { less than } 1 \mathrm{~mm} \text { in fine } \\
\text { grained rocks, } 1-3 \mathrm{~mm} \\
\text { in coarser grain rocks. }\end{array}$ & $\begin{array}{l}\text { Varies from no cleavage } \\
\text { to a crenulate cleavage } \\
\text { to a slip cleavage and } \\
\text { finally to a spaced } \\
\text { schistosity. }\end{array}$ & $\begin{array}{l}\text { Generally no axial-sur- } \\
\text { face cleavage. Crenulate } \\
\text { cleavage is only poorly } \\
\text { developed in areas of } \\
\text { highest strain. }\end{array}$ \\
\hline $\begin{array}{l}\text { Relation to min- } \\
\text { eral lineation. }\end{array}$ & Unknown -.----- & Parallel to hinge -....-. & Deforms mineral lineation_ & Same as $F_{3}$. \\
\hline $\begin{array}{l}\text { Sense of } \\
\text { rotation. }\end{array}$ & Difficult to assess - & $\begin{array}{l}\text { Clockwise and counter- } \\
\text { clockwise. }\end{array}$ & $\begin{array}{l}\text { Clockwise and counter- } \\
\text { clockwise. }\end{array}$ & Same as $\mathrm{F}_{3}$. \\
\hline Fold order & Indeterminate & At least 2 & At least 2 & Same as $\mathbf{F}_{3}$ \\
\hline Abundance ---- & $\begin{array}{l}\text { Rare. only nbserved } \\
\text { in thin-bedded } \\
\text { member of the } \\
\text { Cobble Mountain } \\
\text { Formation. }\end{array}$ & $\begin{array}{l}\text { Plentiful in the More- } \\
\text { town and Cobble Moun- } \\
\text { tain Formations. Iden- } \\
\text { tified by graded beds in } \\
\text { the Goshen Formation. }\end{array}$ & $\begin{array}{l}\text { Most abundant in schist, } \\
\text { intensity varies with } \\
\text { major folds of the same } \\
\text { age. }\end{array}$ & $\begin{array}{l}\text { Only moderately abundant } \\
\text { in schist where the axial } \\
\text { surface cleavage of } \mathrm{F}_{3} \text { is } \\
\text { sharply folded. }\end{array}$ \\
\hline
\end{tabular}

The axial-surface maps were constructed by plotting all available orientation data for a given minor fold generation. The orientation of axial surfaces between data points was interpolated where the surrounding coverage was dense. The density of these surfaces on each map represents the abundance of data in any one area. The resulting maps (figs. 63, 67, 69, 73, 74, 75, and 76) show: (1) the systematic change in orientation of axial surfaces from place to place; (2) the areas of intense deformation associated with each fold generation; and (3) the relationship of each minor fold generation to the major structures of the area.

\section{TERMINOLOGY}

Minor fold generations are designated, from oldest to youngest, $F_{1}, F_{2}, \ldots F_{n}$ in the three areas discussed in this chapter. Each generation is considered the result of a broadly coeval stress field. Identical fold designations, however, in areas separated by $10 \mathrm{~km}$ or more do not necessarily imply a similar age although the generations are coeval more often than not. For example, $F_{3}(?)$ in Newtown is not coeval with $\mathrm{F}_{3}$ in Collinsville or in the Blandford-Woronoco area (fig. 78). Correlation of fold generations between these areas depends on a number of factors, the most important of which is a dense network of outcrops with fold generations in superposed rela- tionship. Furthermore, it must be emphasized that correlative fold generations based on high-quality data may not be coeval in a strict time sense. Although $\mathrm{F}_{2}$ in Newtown and Collinsville may indeed be a product of the same stress field and correlative according to reliable criteria, it may well have developed nonsimultaneously in the two areas as a result of a progressive change in the controlling parameters of deformation (temperature, confining pressure, stress intensity, and so forth). These effects have not been evaluated in this study.

Designations for cleavages which are parallel to the axial surfaces of minor folds include the terms "schistosity, crenulate cleavage, slip cleavage, and spaced schistosity." The term "schistosity" is restricted to cleavages where the micas are all essentially oriented parallel to the cleavage plane in the rock. "Crenulate cleavage" is formed by the parallelism of short limbs of crenulate folds in schist. Although discrete planes of slip or fabric discontinuity are not present on the scale of the thin section or hand specimen (fig. 64A), a distinct surface where the micas abruptly change orientation does exist on the scale of the outcrop. "Slip cleavage" is a more advanced stage of crenulate cleavage; here discrete slip has occurred across the cleavage plane and the rock commonly breaks along this surface (figs. $64 B$ and $65 B$ ). In both crenulate cleavage 


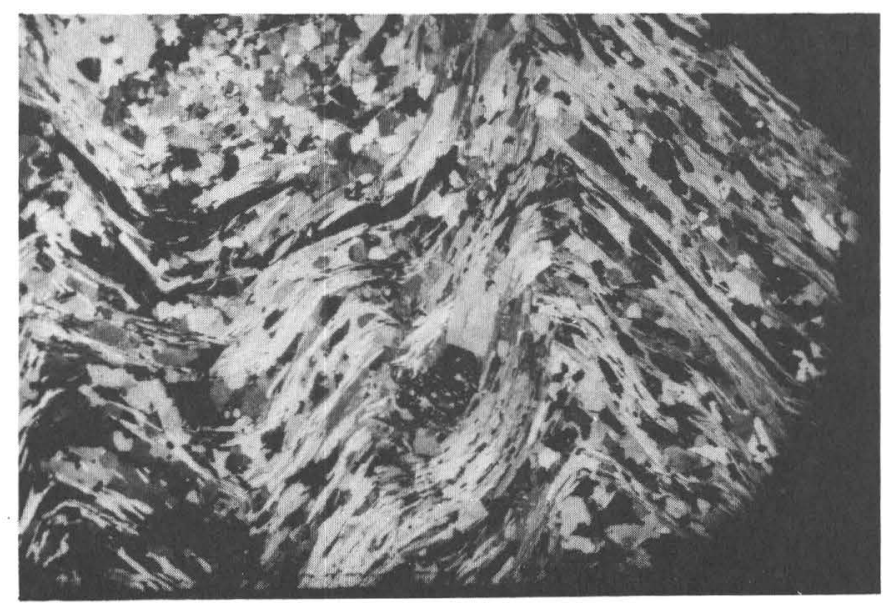

$A$

$$
1.0 \mathrm{~cm}
$$

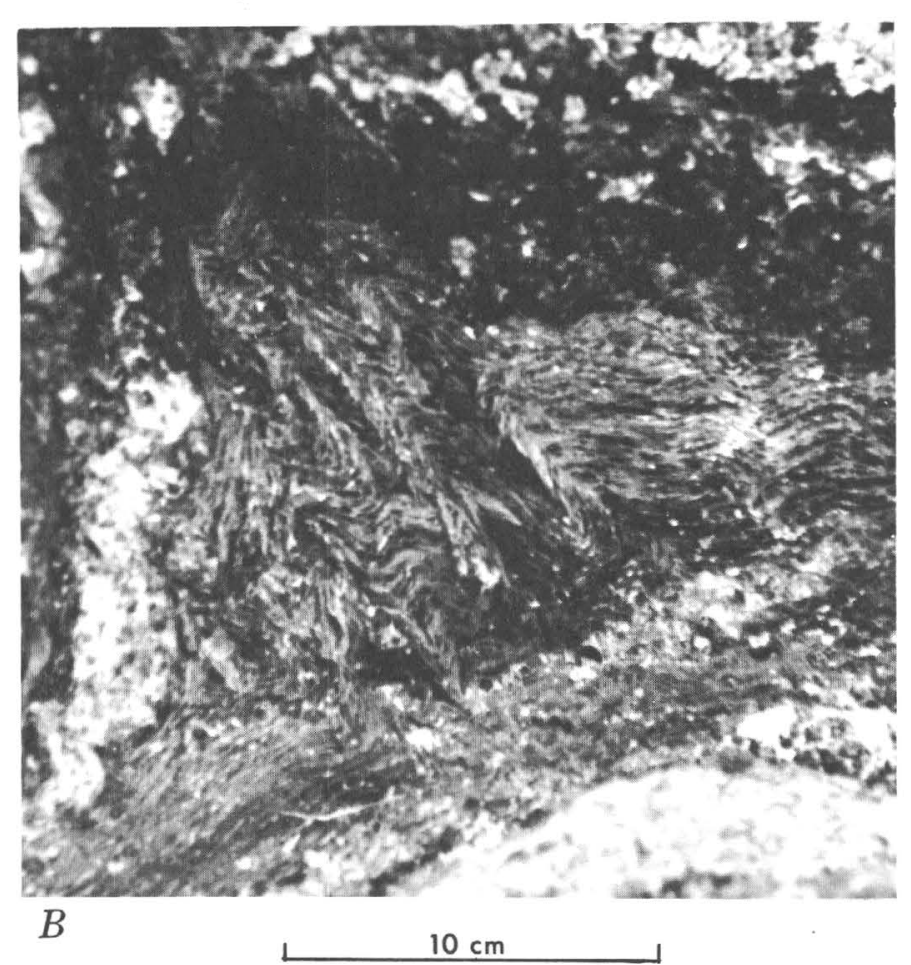

and slip cleavage the micas are oriented at an angle to the cleavage plane. "Spaced schistosity" refers to highly deformed slip cleavage in which the rock is divided into two fabric domains: (1) the actual cleavage planes where the micas are parallel or closely parallel to the cleavage; and (2) the intercleavage domains where the micas are discordant to the cleavage. The latter commonly form the remains of small crenulate folds which were a dominant fabric element in the less deformed stage of

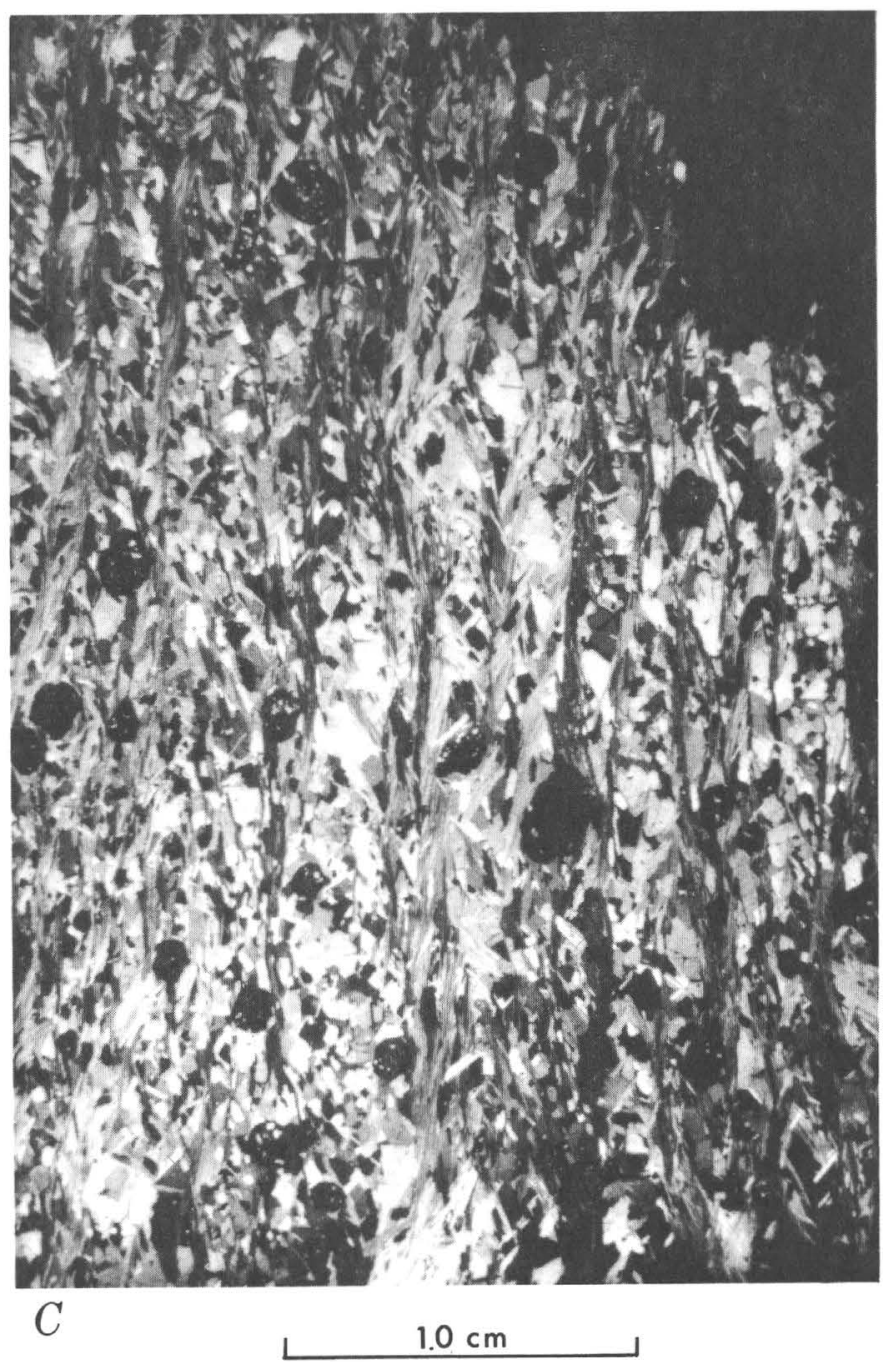

Figure 64.-The development of cleavage in schistose rocks. Thin section $A$ shows penetrative schistosity of $\mathrm{F}_{2}$ deformed by $F_{:}$crenulate folds, with the development of crenulate cleavage along the limbs. Crossed polarizers. $B$ shows slip cleavage in a thin bed of schist at the hinge of an $F_{3}$ fold. Thin section $C$ shows spaced schistority of $F_{::}$folds. Crossed polarizers.

crenulate cleavage (figs. $64 C$ and $65 D$ ). Crenulate cleavage, slip cleavage, and spaced schistosity are part of an overall sequence of cleavage development; each stage represents a higher level of strain. The boundaries between these stages are gradational and quite arbitrary as they have not been quantified. Although this sequence is commonly typical of $\mathrm{F}_{3}$, there is sufficient evidence to indicate that it is the dominant mechanism of cleavage development in all four fold generations. 

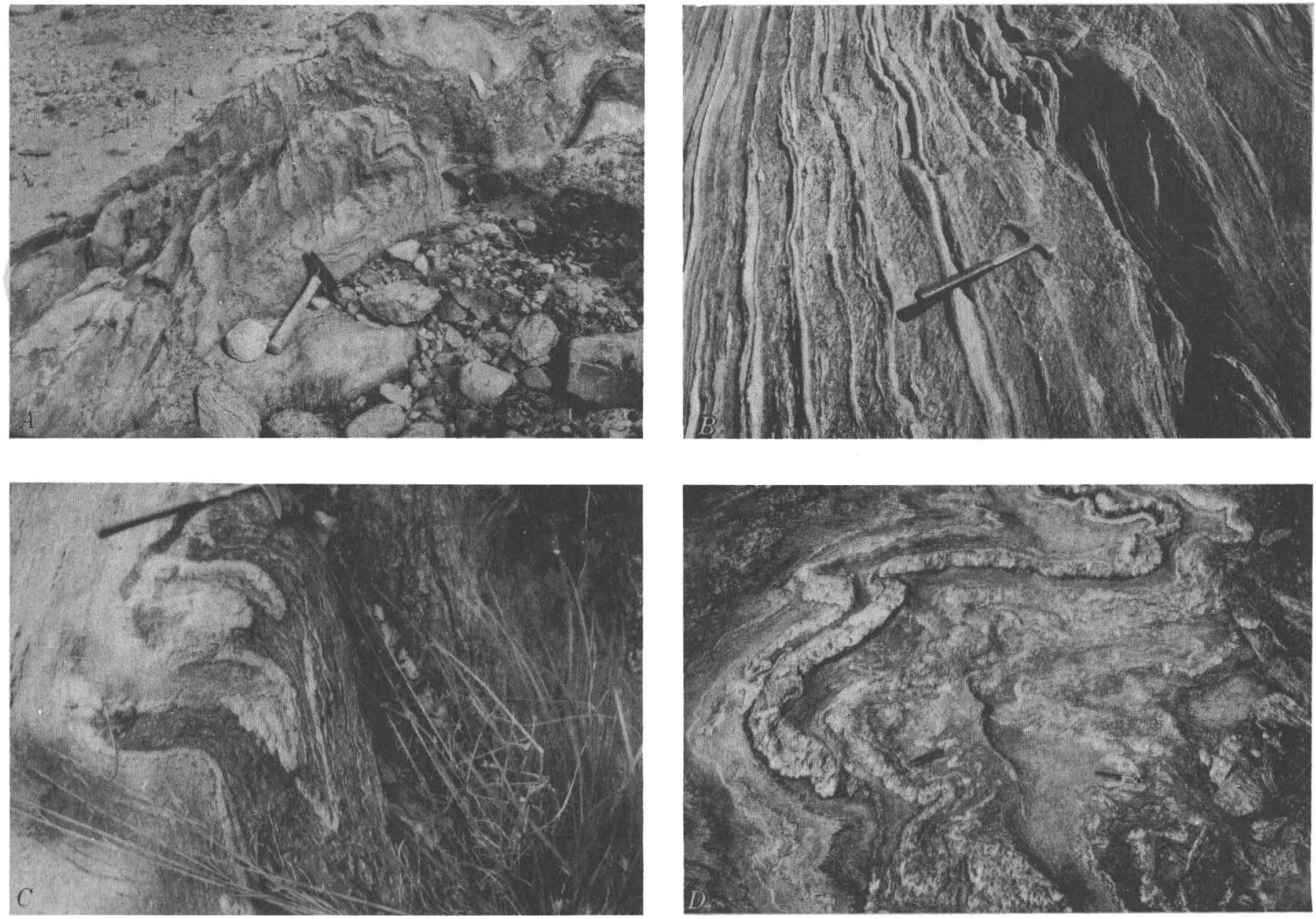

FIGURE 65-Minor folds of generation $\mathrm{F}_{1}$ through $\mathrm{F}_{4}$, Cobble Mountain Reservoir. $A$ shows a sequence of thin beds of schist and granulite. $F_{1}$ folds, directly over hammer head, are outlined by bedding. $F_{2}$ folds are prevalent in the outcrop. Axialsurface schistosity of $\mathrm{F}_{2}$ parallels hammer handle. $B$ shows $\mathrm{F}_{3}$ folds with slip cleavage superposed on bedding and the axialsurface schistosity of $F_{2}$, which is nearly parallel to bedding. $C$ is an $F_{2}$ fold with axial-surface schistosity refolded by an $\mathrm{F}_{3}$ fold. Crenulate cleavage is only apparent in the lower fold of the bed of amphibolite (dark gray unit). $D$ shows a very broad $F_{4}$ fold deforming the spaced schistosity of $F_{3}$ folds. Pencil and knife are parallel to spaced schistosity, which is most obvious in the lower left of the photograph.

\section{BLANDFORD-WORONOCO AREA, SOUTHWESTERN MASSACHUSETTS}

The Blandford-Woronoco area contains the metamorphosed eugeosynclinal rocks that extend southward from the north-south tier of quadrangles discussed by Hatch (1975). Here the pre-Triassic rocks have been metamorphosed to the kyanite and sillimanite grades, and the pre-Silurian unconformity has been severely deformed on all scales by the youngest two of the four minor fold generations recognized by Hatch to the north. Triassic deformation is marked by normal faulting. The general geology of these areas is shown in figures 63,67 , and 69 , and a representative cross section is presented in figure 71, diagram 4 .

\section{FOLD-GENERATION CHARACTERISTICS}

The minor folds in the Blandford-Woronoco area are grouped into four fold generations $\left(\mathrm{F}_{1}-\mathrm{F}_{4}\right)$ according to superposed relationships displayed in well exposed areas of dense outcrop. The important descriptive features of each of these generations are listed in table 2 and illustrated in the photographs of figures 64 and 65 . These same characteristics apply to minor folds in both the Collinsville and Newtown quadrangles.

Of the eight descriptive characteristics listed in table 2, profile form and axial-surface cleavage are by far the most useful and reliable identifying features of each generation. Folds of the two older generations are commonly tight to isoclinal in pro- 
file. An excellent axial-surface schistosity is everywhere present in $F_{2}$ folds. Although $F_{1}$ folds nowhere have a cleavage marking the axial surface, some of the $\mathrm{F}_{2}$ hinges have a few micas discordant to the $\mathrm{F}_{2}$ axial-surface schistosity and the bedding. These micas form limbs of very tight chevron folds whose axial surfaces are parallel to the $F_{2}$ schistosity. The limb micas represent an older schistosity that has been almost totally obliterated by the development of the penetrative schistosity of the $\mathrm{F}_{2}$ folds.

Folds of the two younger generations are generally crenulate in profile in the schists of the area and are commonly more open and quite distinct from the older two generations. Cleavage is commonly not present in the youngest fold generation $\left(\mathrm{F}_{4}\right)$, except for a crenulate cleavage that is poorly developed in some of the tighter, more highly deformed folds of this generation. $\mathrm{F}_{4}$ folds are most easily recognized where the crenulate cleavage, slip cleavage, or spaced schistosity of $\mathrm{F}_{3}$ folds is systematically bent by $\mathrm{F}_{4}$ (fig. 65D).

Folds of $\mathrm{F}_{3}$ display the greatest range in cleavage development (fig. 64). In the south-central part of the Blandford-Woronoco area, very weakly developed crenulate folds without cleavage are progressively deformed to folds first having crenulate cleavage, then having slip cleavage, and finally having a well-developed spaced schistosity (see fig. 64 and $65 B, D$; see also Stanley, 1967, stops 1-8). These three stages represent higher levels of strain within $\mathrm{F}_{3}$ and are also used as an indicator of the intensity of deformation for other fold generations. It must be emphasized, however, that the strain represented by each generation is a summation of strain associated with the development of that generation plus the additional strain imposed on it by younger superimposed folds. No attempt has been made to separate these in this study.

Let us now consider the intensity of strain and the range of intensities associated with each minor fold generation as indicated by cleavage. Little can be said for $F_{1}$ because of few observations. A schistosity presumably existed but it has been largely obliterated by recrystallization and repeated deformation in the three younger fold generations. The $\mathrm{F}_{2}$ folds represent a uniformly high level of strain because the associated cleavage is everywhere a well-developed, penetrative schistosity. The strain level of $\mathrm{F}_{3}$ shows the greatest range of all four generations; the strain level may vary systematically through most of the cleavage stages within an area of less than [a square mile] $2.5 \mathrm{~km}^{2}$. High levels of strain are located along the hinges and east limbs of major folds in the central part of the BlandfordWoronoco area and in the synform in the southeastern part of the area ( $\mathrm{E}$ on fig. 67 ). The strain level appears to drop off both to the north and west. The major antiform in the central part of the Blandford-Woronoco area was in part developed during $\mathrm{F}_{4}$ time (B on fig. 67), so the high level of strain represented by $\mathrm{F}_{3}$ folds on the antiform's eastern limb is thus a product of the strain associated with both $\mathrm{F}_{3}$ and $\mathrm{F}_{4}$.

The $\mathrm{F}_{4}$ folds represent a relatively low-level of strain with a restricted range. Generally, the minor folds are broad undulations that only developed into fairly tight crenulate folds along the antiform outlined by the eastern bend in the base of the Goshen Formation (DSg, fig. 69).

\section{AXIAL-SURFACE MAPS}

Axial-surface maps have been prepared for the youngest three generations of minor folds in the Blandford-Woronoco area; no such map for $F_{1}$ was prepared because of few reliable observations. However, $F_{1}$ folds are numerous in the lower member of the Cobble Mountain Formation, as well-preserved graded beds are either normal or inverted on minor antiformal folds of $\mathrm{F}_{2}$.

As shown on the axial-surface maps, most of the minor-fold data are confined to the Ordovician rocks in the Blandford-Woronoco area, because the outcrop is very abundant in this area and is more limited to the west. The area underlain by Devonian and Silurian rocks has been mapped by Hatch and S. F. Clark, Jr., and is excluded from this study. My work, however, has included a detailed study of the basal $100 \mathrm{~m}$ of the Devonian and Silurian section.

$\mathrm{F}_{2}$ folds.-Figure 63 is based on 270 axial surfaces of $\mathrm{F}_{2}$ minor folds distributed rather evenly in the area of study. The axial surfaces of these minor folds are systematically folded by most of the major folds labelled by letters $\mathrm{A}$ through $\mathrm{F}$ in figure 63 and, hence, are older than folds A-F. Two of these younger folds (A and D) are outlined by the Taconic unconformity. In the pre-Silurian rocks a large refolded antiform outlined by the contact between the lower and upper members of the Cobble Mountain Formation is the largest and most conspicuous major structure of $\mathrm{F}_{2}$ age. The nose of this fold, here called the Woronoco fold, is situated at locality 1 (fig. 63) where the schistosity trends at right angles to the bedding and almost totally obliterates it. A higher order $\mathrm{F}_{2}$ hinge is mapped at locality 2 (fig. 63). Close inspection of the contact between the two members of the Cobble Mountain Formation (Ocl 
and Ocu, fig. 63) shows that south of locality 1 the axial schistosity of $\mathrm{F}_{2}$ folds cuts the map contact (bedding) at an acute angle with a sinistral sense (as indicated by an arrow drawn from the axial surface normal to the bedding normal in spherical projection). North of locality 1 , except just south of locality 2 , the sense has changed to dextral. The generalized trace of the axial surface of this major antiform (heavy line on fig. 63) is located in the lower member of the Cobble Mountain Formation and is systematically folded by the younger antiform $\mathrm{B}$ and synform $\mathrm{C}$ (fig. 63). The nose of this older major fold along the contact at the base of the Devonian and Silurian section appears to be somewhere to the south under the Triassic rocks, because the axial schistosity cuts this contact at an acute angle having a dextral sense.

The axial-surface schistosity of $F_{2}$ folds is identical to the regional schistosity that parallels the axial surfaces of the isoclinal folds in the Goshen Formation described by Hatch $(1968,1975)$. This relationship is best seen along the eastern side of the Blandford-Woronoco area south of the letter $\mathrm{D}$ on figure 63. The minor folds of $\mathrm{F}_{2}$ are, therefore, coeval with the folds of stage II described by Hatch. Although the unconformity at the base of the Goshen Formation in and north of the Blandford-Woronoco area is apparently undeformed by the major isoclinal folds that fold the Goshen, the base of the Devonian and Silurian section to the south in western Connecticut is highly folded around and in between the gneiss domes (figs. 62 and 79). Many of these folds appear to be correlative with $\mathrm{F}_{2}$ in the BlandfordWoronoco area because the regional schistosity is parallel to their axial surfaces and the axial surfaces of isoclinal minor folds delineated by graded beds in the Devonian and Silurian rocks. The axial surface of one of these major folds is shown in the southern part of the Blandford-Woronoco area in figure 63 .

The age of the small folds in the upper member of the Cobble Mountain Formation along the eastern limb of antiform D (fig. 63) is somewhat in doubt. The two southern folds just east of locality 1 appear to be cut by the regional schistosity. Based on sparce data, both of these folds may be of $F_{1}$ age. The northernmost fold in this belt is $F_{2}$ in age as its axial surface is essentially coplanar with the axial surface of $\mathrm{F}_{2}$ minor folds.

Fold axes and poles to axial surfaces of $\mathrm{F}_{2}$ folds are shown for five subareas in figure 66. Orientation data for each subarea are listed in table 3. In diagrams $A, B$, and $C$, thr! $\pi$ pole for each axial-surface girdle is oriented within the cluster of points representing fold axes. This relationship indicates that the axial schistosity of $\mathrm{F}_{2}$ is folded about younger axes that are generally parallel with the fold axes of $F_{2}$. Local departures from parallelism, however, do exist at the outcrop. Because the $\pi$ poles for subareas $A, B$, and $C$ are nearly parallel, the axes of subsequent folding was essentially parallel throughout most of the area in figure 63. Diagrams $D$ and $F$ are small subareas where the $\pi$ pole is either based on insufficient data ( $D$, fig. 66$)$ or appears to be steeply inclined ( $F$, fig. 66). A unique $\pi$ pole is not shown in diagram $F$ since the data are so scattered.

$F_{3}$ folds.-Figure 67 is based on the axial surfaces of $900 \mathrm{~F}_{3}$ folds, of which 650 are plotted as data points for the axial-surface map. Areas of high strain level are located in the major folds at $H$, in the fold at $\mathrm{F}$, on the east limb of antiform $\mathrm{B}$, and in the synform which is continuous from $\mathrm{C}$ to $\mathrm{E}$ (fig. 67). In these areas the slip cleavage is well developed and the folds are tight. A spaced schistosity is developed at $\mathrm{F}$ and some of the other localities. The axial surface cleavages of $F_{2}$ and $F_{3}$ are nearly parallel along the east limb of antiform $B$, but can be separated here by their differences in form. Perhaps the greatest divergence in orientation is in synform $\mathrm{E}$, where the axial surface of $\mathrm{F}_{3}$ trends northwestward across the folded axial surfaces of the older $\mathrm{F}_{2}$ folds (compare figs. 63 and 67).

The axial surfaces of $F_{3}$ folds are systematically deformed into a series of broad cleavage antiforms and synforms. These folds become a single broad antiform or arch to the north near the contact between the Devonian and Silurian rocks and the underlying formations (north of $B$ on fig. 67). The large folds at $B$ and $D$ and the smaller fold just northeast of $\mathrm{C}$ are clearly younger in age than $\mathrm{F}_{3}$ since they fold this cleavage. The unusual map pattern at $G$ is in part a result of deformation of $F_{3}$ folds, as their axial surfaces appear to outline a series of small folds. This map pattern and the one between $F$ and $G$ suggest that the rocks in this area were displaced southwestward during $\mathrm{F}_{4}$ time. The major fold at $A$, the folds to the south and west of $A$, the folds at $H$, part of the fold at $F$, the major synform that is continuous from $\mathrm{C}$ to $\mathrm{E}$, and the small fold at 1 are all coeval with $F_{3}$ minor folds, because the calculated axial surface of these mappable structures is statistically parallel to $F_{3}$ minor folds. The two major folds ( $\mathrm{A}$ and $\mathrm{D}$ ) along the Taconic unconformity are, therefore, of two quite 


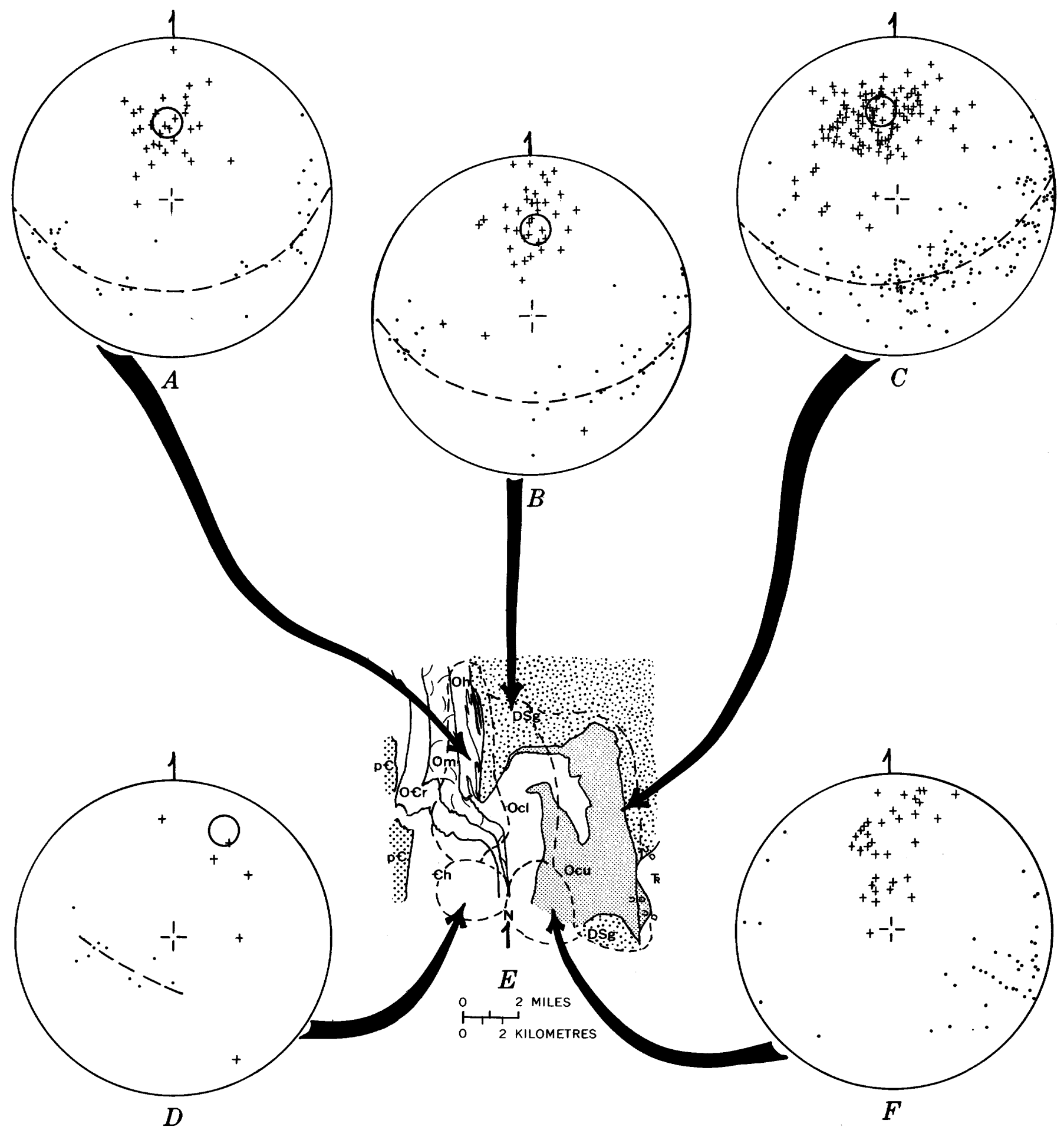

FigURE 66.-Lower hemisphere equal-area projection of poles to $F_{2}$ axial surfaces $(\bullet)$ and $F_{2}$ fold axes $(+)$ for five subareas in the Blandford-Woronoco area. The dashed lines are great circles that approximate the distribution of poles to axial surfaces. The pole to the great circle $(\pi$ pole $)$ is shown by the center of the 1 percent circle. Orientation data are listed in table 3. Subarea $A, 40$ axial surfaces, 26 fold axes; subarea $B, 47$ axial surfaces, 23 fold axes; subarea $C$, 165 axial surfaces, 107 fold axes; subarea $D, 12$ axial surfaces, 6 fold axes; subarea $F, 42$ axial surfaces, 32 fold axes. Plane of projection is horizontal with north indicated by arrow. 
TABLE 3.-Orientation data for equal-area projections in figures 66,68 , and 70

\begin{tabular}{|c|c|c|c|c|}
\hline Subarea & $\begin{array}{l}\text { Pattern of poles to } \\
\text { axial surfaces }\end{array}$ & $\begin{array}{c}\text { Dip and strike of } \\
\text { pole to girdle } \\
\text { (conter of 1-percent circle) }\end{array}$ & $\begin{array}{c}\text { Dip and strike of surface } \\
\text { corresponding to point } \\
\text { maximum }\end{array}$ & $\begin{array}{c}\text { Fold-axis } \\
\text { maximum }\end{array}$ \\
\hline 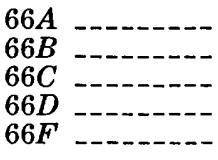 & $\begin{array}{l}\text { Incomplete girdle } \\
\text { Incomplete girdle } \\
\text { Incomplete girdle } \\
\text { Very incomplete girdle } \\
\text { Very diffuse point maximum }\end{array}$ & $\begin{array}{ll}50^{\circ} & \text { N. } 4^{\circ} \text { W } \\
45^{\circ} & \text { N. } 4^{\circ} \text { E } \\
45^{\circ} & \text { N. } 10^{\circ} \text { W }-\cdots \\
25^{\circ} & \text { N. } 28^{\circ} \text { E }\end{array}$ & Steep W. N. $20^{\circ}$ E & 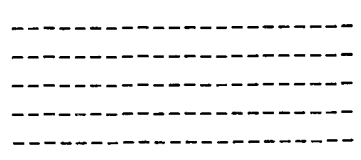 \\
\hline $\begin{array}{l}68 A \\
68 B \\
68 C \\
68 D \\
68 F-\cdots-1-\cdots \\
68 F\end{array}$ & $\begin{array}{l}\text { Incomplete girdle } \\
\text { Complete girdle } \\
\text { Diffuse point maximum } \\
\text { Complete girdle } \\
\text { Point maximum }\end{array}$ & $\begin{array}{l}60^{\circ} \text { N. } 2^{\circ} \mathrm{W} \\
45^{\circ} \text { N. } 5^{\circ} \mathrm{W}- \\
\overline{55} 5^{\circ} \text { N. } 5^{\circ} \mathrm{W}_{-}\end{array}$ & $85^{\circ}$ E. N. $45^{\circ} \mathrm{W}^{\circ}$ E. N. $30^{\circ} \overline{\mathrm{W}}_{-}$ & 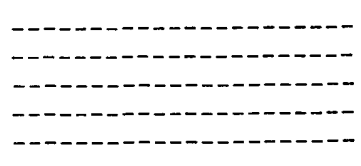 \\
\hline $\begin{array}{l}70 A \\
70 B \\
70 C \\
70-\cdots-\cdots\end{array}$ & $\begin{array}{l}\text { Point maximum } \\
\text { Point maximum } \\
\text { Point maximum }\end{array}$ & 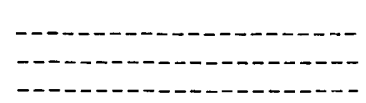 & 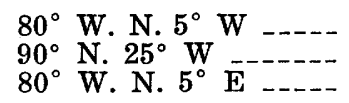 & $\begin{array}{l}45^{\circ} \mathrm{N} \cdot 15^{\circ} \mathrm{W} . \\
50^{\circ} \mathrm{N} .25^{\circ} \mathrm{W} \\
45^{\circ} \text { N. } 7^{\circ} \mathrm{W} .\end{array}$ \\
\hline
\end{tabular}

different ages, although their general orientation seems identical on the map.

The Woronco fold, the smaller folds in the upper part of the Cobble Mountain Formation along the east limb of antiform $\mathrm{D}$, and the isoclinal folds in the Goshen Formation are clearly older than $F_{3}$ since their axial surfaces are deformed by $F_{3}$.

Fold axes and poles to axial surfaces of $F_{3}$ folds are shown for five subareas in figure 68. These subareas do not coincide with those for $F_{2}$ folds, although considerable overlap does exist. Orientation data for the five subareas are listed in table 3. In three of the five subareas the $\pi$ poles to the axialsurface girdles fall within the cluster of fold axes, thus indicating that the axes of $F_{4}$ major folds are generally parallel with the axes of the older $\mathrm{F}_{3}$ folds. It thus appears that on a subarea basis the $\pi$ poles of $\mathrm{F}_{2}$ and $\mathrm{F}_{3}$ axial-surface girdles are generally parallel or nearly so (compare fig. 66 with fig. 68 , and table 3).

The poles to axial surfaces in subareas $C$ and $F$ (fig. 68) form distinct point maxima which correspond to statistical surfaces striking northwesterly and dipping steeply to the northeast (see table 3 and the eastern part of fig. 67). Although a partial great circle girdle is present in $A$ (fig. 68), many of the axial surfaces strike northeast and dip steeply to the northwest.

$F_{4}$ folds.-Figure 69 shows axial surfaces of 106 minor $\mathrm{F}_{4}$ folds, of which 32 deform the slip cleavage of $\mathrm{F}_{3}$ folds (fig. 65D). The remaining 74 crenulate folds are assigned to this generation because their axial surfaces are parallel to the 32 known $F_{4}$ folds and discordant to $\mathrm{F}_{3}$ folds, although the two sets are not directly superimposed.

Those $\mathrm{F}_{4}$ folds that directly fold the older slip cleavage (heavy barbell symbol, fig. 69) are best developed and more numerous along the axial traces of major $\mathrm{F}_{4}$ folds (compare figs. 67 and 69). The strain associated with $\mathrm{F}_{4}$ folds is slightly more in- tense along the easternmost antiform than it is to the west. Theoretically, hinge zones in many types of folds (flexural slip, bend-and-buckle folds) are regions of large strain. In slip or passive folds, however, the strain is more evenly distributed throughout the fold. Figures 67 and 69 indicate that folding during $F_{4}$ was generally accomplished by a flexural-slip mechanism as a result of east-west compression of the older axial surfaces.

The axial surfaces of $F_{4}$ folds directly superimposed on $\mathrm{F}_{3}$ folds trend to the north and dip steeply to the west and are very similar to the crenulate folds in subarea $C$ along the eastern part of the area (fig. 70, table 3). To the west, however, the axial surfaces trend more westerly. The $\mathbf{F}_{4}$ axes plunge at intermediate angles along a trend slightly west of north. The axes are remarkably similar in orientation to those of the older fold generations.

\section{SUMMARY}

The previous discussion of fold generations in the Blanford-Woronoco area has suggested the following important conclusions :

1. Axial surfaces of minor folds provide a means of determining the relative age of major structures which otherwise may be ambiguous or indeterminate. If the axial surfaces of a given fold generation are statistically parallel to the calculated axial surface of the major fold, then the two are coeval. Older and younger ages are based on cross-cutting relations.

2. The angular relationship between formation contacts and the axial surfaces of minor folds of a given age can locate the hinge and limb areas of refolded major folds of the same generation.

3. The character or style of axial-surface cleavage (That is, crenulate cleavage, slip cleavage, spaced schistosity) in a specific rock type is a reliable but qualitative measure of strain for each fold generation.

4. The axes of minor folds and major cleavage folds 


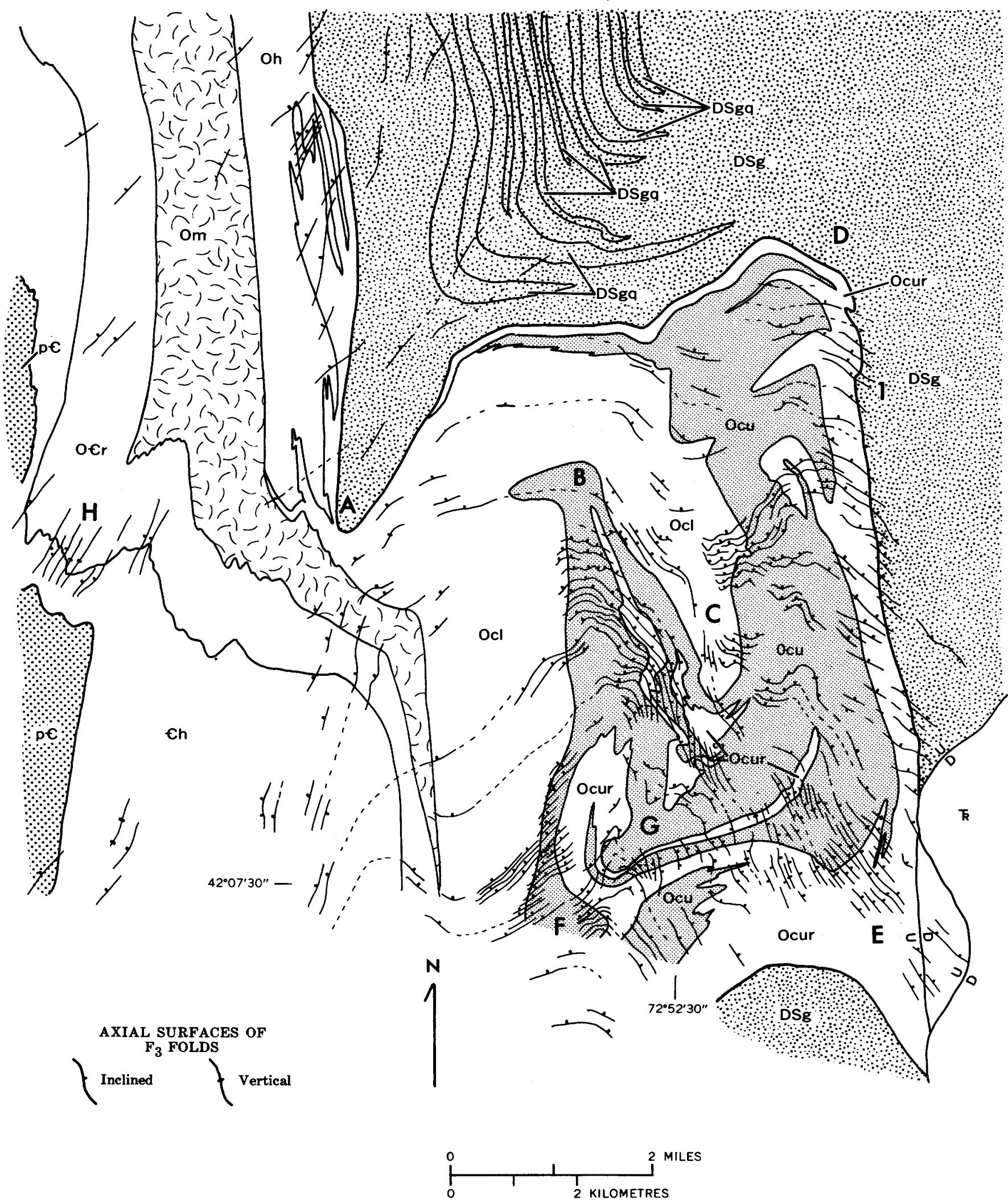

Figure 67.-Geologic map of the Blandford-Woronoco area showing axial surfaces of $F_{3}$ folds. Stratigraphic units and symbols are listed in table 1 and described in figure 63. Letters $A$ through $H$ and number 1 are discussed in text. 


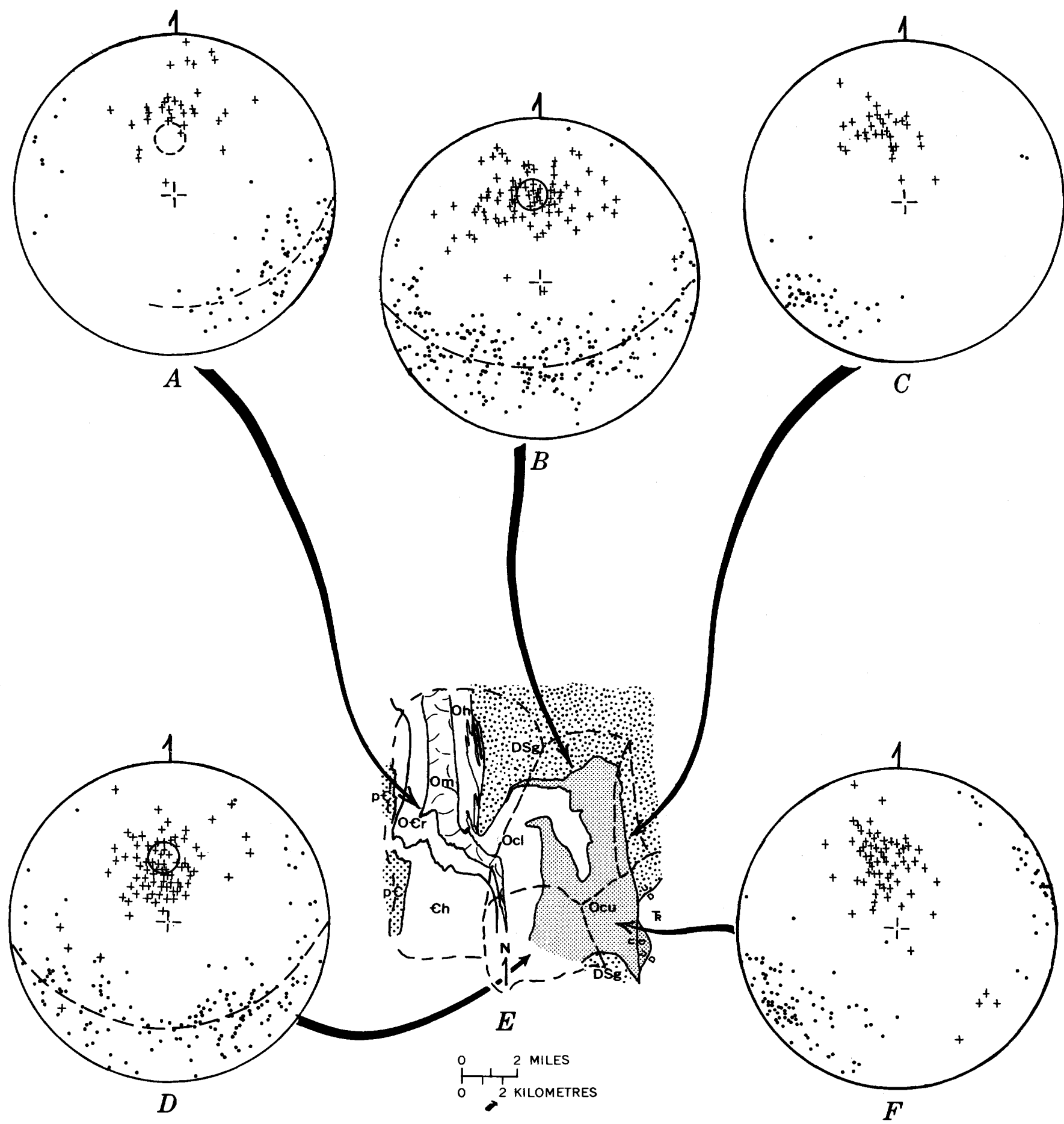

FiguRe 68.-Lower hemisphere equal-area projections of poles to $F_{3}$ axial surfaces $(\bullet)$ and $F_{2}$ fold axes $(+)$ for five subareas in the Blandford-Woronoco area. The dashed lines are great circles that approximate the distribution of axial surface normals. The center of the 1 percent circle $(\pi$ pole $)$ is the pole to the great circle. Orientation data are listed in table 3. Subarea $A, 79$ axial surfaces, 32 fold axes; Subarea $B, 235$ axial surfaces, 85 fold axes; subarea $C$, 46 axial surfaces, 32 fold axes; subarea $D, 158$ axial surfaces, 83 fold axes; subarea $F, 118$ axial surfaces, 68 fold axes. Plane of projecticn is horizontal with north indicated by arrow. 




Figure 69.-Geologic map of the Blandford-Woronoco area showing axial surfaces of $F_{1}$ folds. Heavy barbell symbols represent $F_{1}$ folds that deform slip cleavage of $F_{3}$ folds. Light symbols are $F_{1}$ folds that deform $F_{2}$ schistosity. Stratigraphic units and symbols are listed in table 1 and described in figure 63. 

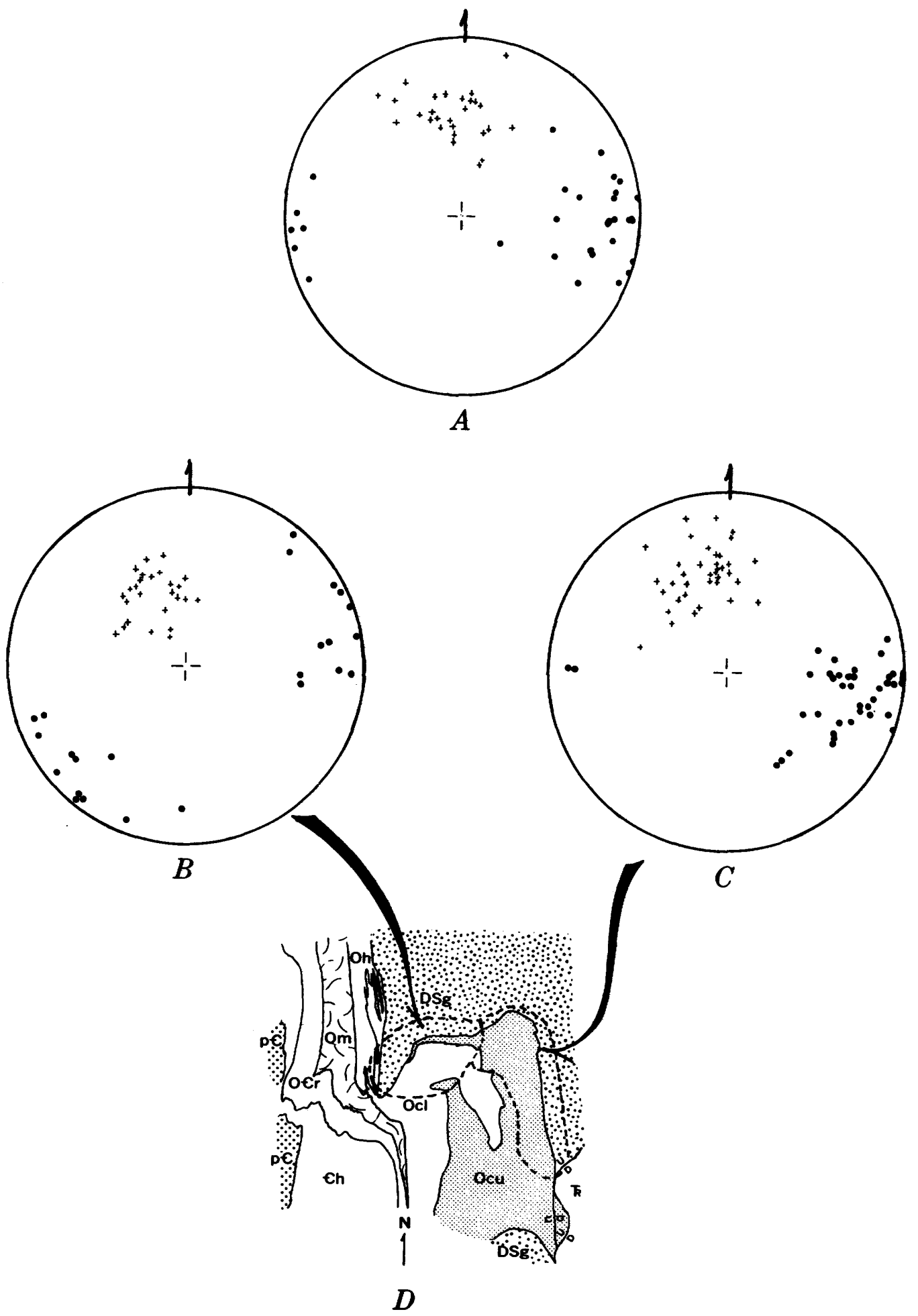

$\overbrace{0}^{0} \underbrace{2}_{2 \text { KILOMETRES }}$

Figure 70.- Lower hemisphere equal-area projections of poles to $F_{4}$ axial surfaces $(\bullet)$ and $F_{4}$ fold axes $(+)$ for 2 subareas in the Blandford-Woronoco area. Diagram $A$ contains folds that deform the slip cleavage of $\mathrm{F}_{3}$ folds in both of the areas shown by $B$ and $C$. Diagrams $B$ and $C$ contain folds that deform only $\mathrm{F}_{2}$ schistosity. Subarea $A, 31$ axial surfaces, 27 fold axes; subarea $B, 27$ axial surfaces, 26 fold axes; subarea $C, 41$ axial surfaces, 37 fold axes. Plane of projection is horizontal with north indicated by arrow. 
for $F_{2}, F_{3}$, and $F_{4}$ are essentially parallel throughout most of the Blandford-Woronoco area. Therefore, deformation has involved repeated folding about parallel axes, developing discordant axial-surface cleavages. This constraint simplifies subsequent kinematic and dynamic analysis.

5. The base of the Devonian and Silurian section marks a surface of structural décollement inasmuch as the ratio of amplitude to wavelength is much higher in the younger rocks than in the pre-Silurian section.

\section{STRUCTURAL EVOLUTION}

Any model of the structural evolution for the Blandford-Woronoco area must be highly qualitative and speculative. Information on the mechanism of deformation is almost totally lacking. The effect of metamorphic processes on the rheological properties of rocks can only be surmised. However, an internally consistent and reasonable sequence can be proposed based on the data presented in the foregoing pages. Part of this sequence is diagrammatically shown in figure 71 in profile sections which are drawn perpendicular to the average position of the $\pi$ poles in figures 66,68 , and 70 . The control for diagram 4 in figure 71 is quite good, although the effects of Triassic faulting have been removed. The remaining diagrams are speculative.

The configuration in diagram 4 represents a profile section of the Blandford-Woronoco area at the close of $\mathrm{F}_{4}$ time. The axial trace of the largest $\mathrm{F}_{4}$ cleavage antiform is offset to the west of the symmetry plane of the Granville dome (located directly over the number in each diagram).

Diagram 3 represents a stage in the progressive unfolding of $F_{3}$ axial surfaces. Here the eastern limb is straightened out, forming one large cleavage anticline. In so doing the easternmost contact between pre-Silurian and younger rocks is folded into a large inverted anticline which is required by the Woronoco fold of $\mathrm{F}_{2}$ age (fig. 63). Objectively, this episode is very much open to question because the formation of the inverted anticline should have required large strains which should be preserved in the fabric of the rocks along this belt. Although intrusive granites and pegmatites are plentiful, the deformation appears to be no more intense here than elsewhere. Although the existence of the inverted antiform is highly speculative, it is required by the Woronoco fold and is a consequence of progressively unfolding the $\mathrm{F}_{3}$ structures.

By unfolding the axial surfaces of $F_{3}$, the cleavage antiform of diagram 3 is reduced to the very broad arch of diagrams 2 and $2^{\prime}$. This arch is essentially parallel to the direction of maximum extension developed in mantling rocks as a result of the emplacement of a mantled gneiss dome, according to the mathematical model of Fletcher (1972, p. 210). During this early phase in $\mathrm{F}_{3}$ time, felsic volcanic rocks of Middle Ordovician age are thought to have moved upward, forming elongate domes and modifying the older isoclinal folds. Evidence supporting this event is found to the south in western Connecticut where these volcanic rocks appear to form the cores of several large east-facing folds that have been redeformed into gneiss domes outlined by the contact between the Ordovician-Cambrian and the DevonianSilurian rocks of figures 62 and 79 (Stanley, 1964, 1967, 1968; Dieterich, 1968a and b). In the Blandford-Woronoco area $F_{3}$ folds are considered to be a product of the emplacement of the Granville dome, because their axial surfaces form a cleavage antiform or arch that partly bridges the dome. Further supporting evidence is the fact that $F_{3}$ folds are particularly well developed in the synform between the Granville dome and the recently mapped Woronoco dome just to the northeast (S. F. Clark, Jr., oral commun., 1971). Synclines with abundant crenulate folds are also well developed between the domes in western Connecticut (Stanley, 1964, p. 68). These synclines probaibly developed when the domal rocks moved upward causing the intervening areas to be squeezed together.

Diagrams 2 and $2^{\prime}$ (fig. 71) are alternative interpretations on the attitude of the older isoclinal folds of early $\mathrm{F}_{3}$ time. In both diagrams the upward movement of the lighter volcanic rocks resulted in a fan-shaped compression field in the overlying rocks. Diagram 2, with moderate west-dipping axial surfaces, is preferred since the axial surfaces of $F_{3}$ intersect rock units at a fairly high angle just north of the Granville dome (figs. 67 and 79). This is well illustrated in the lower parts of diagrams 4 and 3 just above the refolded syncline of Devonian and Silurian rocks. In diagram $2^{\prime}$ the axial surfaces of $F_{2}$ and $F_{3}$ intersect at a very small angle. Furthermore, $F_{3}$ folds and their associated cleavage are far more likely to form if the schistosity of $F_{2}$ is compressed at a low angle to the schistosity rather than at a high angle. In diagram $2^{\prime}$ the older schistosity would be compressed at a high angle and hence the tendency to fold it would not be as great.

Older configurations can be visualized by reducing $F_{3}$ axial surfaces to planes. Although a separate diagram was not prepared for $F_{1}$, the appropriate form can be imagined by unfolding the isoclinal 

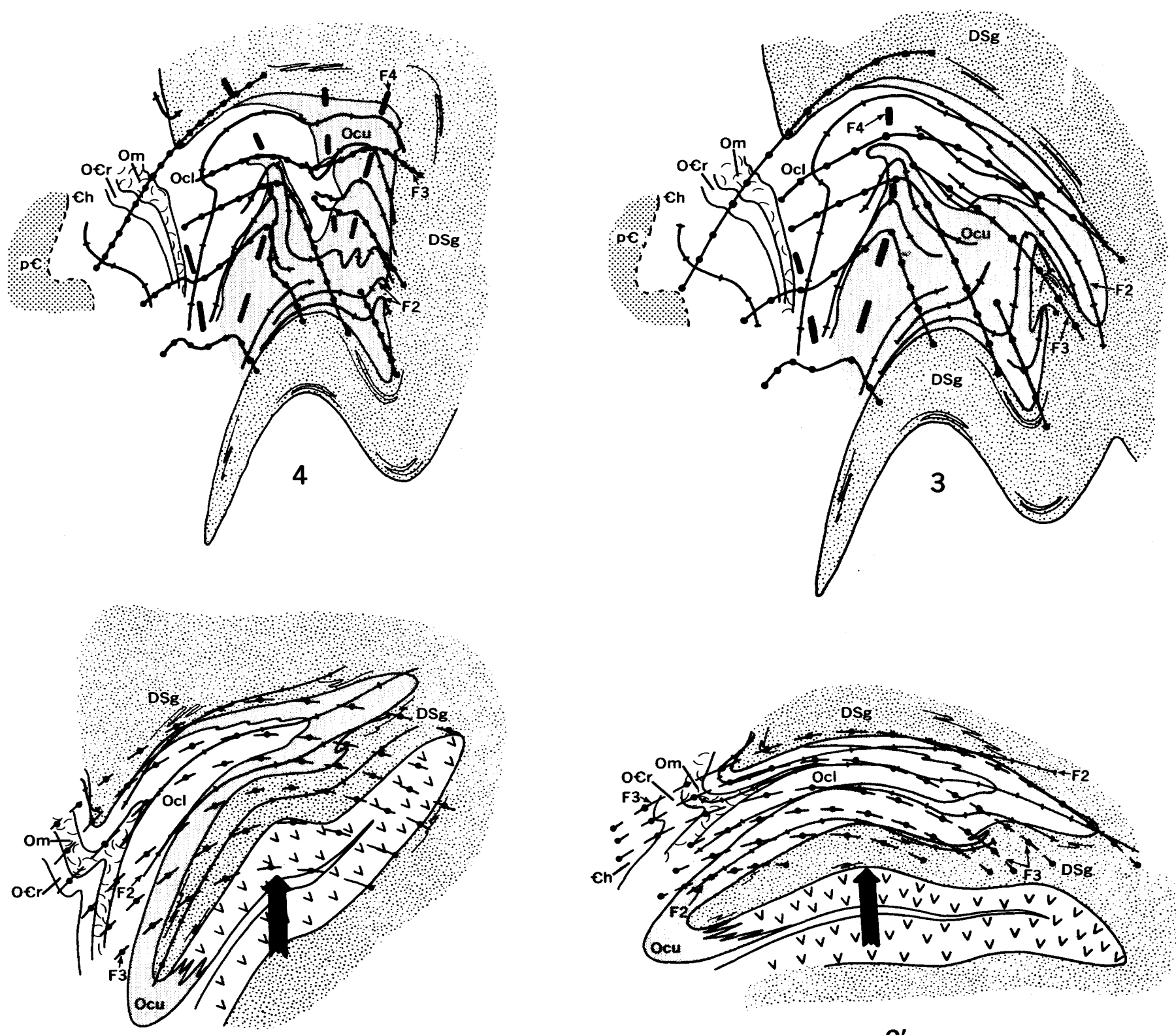

2

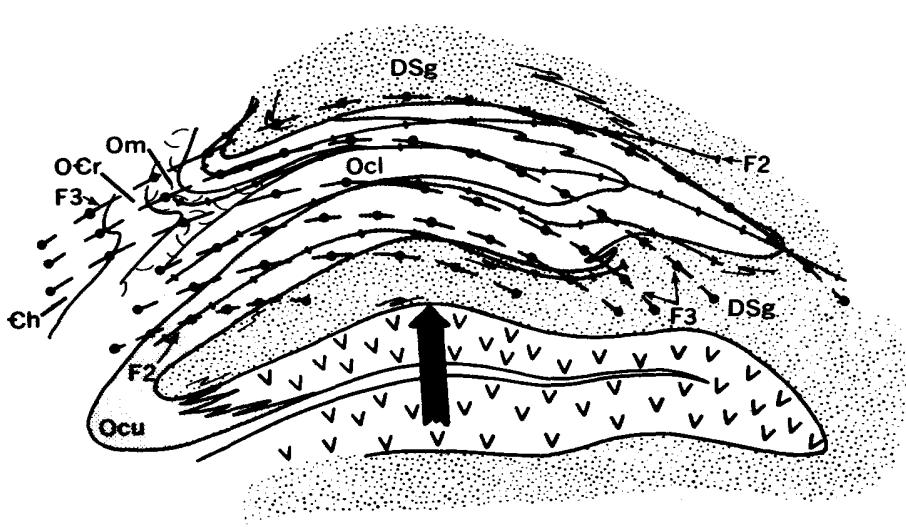

$2^{\prime}$

Figure 71.-Structural evolution of the Blandford-Woronoco area with emphasis on generations 3 and 4 . Diagrams are profile sections drawn perpendicular to an axis oriented approximately $45^{\circ} \mathrm{N}$. $5^{\circ} \mathrm{W}$. Stratigraphic units and symbols are listed in table 1. Axial surfaces of each generation are identified by the symbols $F_{2}, F_{3}$, and $F_{4}$. Diagram 4 shows reconstruction prior to Triassic faulting; diagrams 4,3,2, and (2') show progressively older configurations; diagrams 2 and $2^{\prime}$ are alternative interpretations of early $F_{3}$ time. Granville dome is located approximately in the position of each diagram number.

folds and removing the Devonian and Silurian section. The development of folds in the BlandfordWoronoco area can then be visualized by following the sequence of diagrams from 2 to 4 in figure 10 .

In summary, the structural evolution of the Blandford-Woronoco area in Phanerozoic time began with development of $F_{1}$ folds in rocks of Middle Ordovician and older age. Although structures older than $F_{2}$ and younger than $F_{1}$ have been reported by Os- berg $(1972,1975)$ in the Devonian and Silurian rocks, they do not appear to be the same age as the $F_{1}$ folds. It is tentatively concluded, therefore, that $F_{1}$ folds developed during the Taconic orogeny. Few if any large-scale folds of this generation have been recognized in western Massachusetts, although some small ones have been reported (Hatch, 1975) and several small folds in the upper member of the Cobble Mountain Formation are believed to be of 
this age (fig. 63). The $F_{1}$ folds may well have resulted from intense shearing due to westward thrusting of Ordovician and Cambrian rocks during Taconic time (Norton, 1971, 1975).

The remaining three generations of folds are well developed in the Devonian and Silurian section and are a result of Acadian deformation, since Acadian metamorphism outlasted two if not three of the fold generations (Hatch, 1975). The isoclinal folds of $F_{2}$ are apparently a result of east-west compression in which the axis of maximum compression was inclined at a gentle to moderate eastward angle.

The subsequent rise of the light felsic rocks in the Middle Ordovician section produced the gneiss domes which in turn refolded the older isoclinal folds of $F_{2}$. East-west compression during $F_{4}$ time formed large-scale cleavage folds. In Late Triassic time normal faulting cut the eastern part of the area. Quartz deformation lamellae and microscopic kinking of mica and kyanite may be associated with this final recognizable event.

\section{COLLINSVILLE QUADRANGLE, WESTERN CONNECTICUT}

The metamorphic geology in the Collinsville quadrangle includes rocks of Devonian through Cambrian age that have been folded into northeastwardtrending isoclinal folds and subsequently deformed by the Collinsville and Bristol domes (fig. 79). A detailed discussion of the area was published by me in 1964 and modified in 1968. The revised stratigraphic column is listed in table 1 . The profile section in figure 72 is constructed along line $\mathrm{A}-\mathrm{A}^{\prime}$ of figures 73 and 74 and includes data from the Torrington quadrangle (Martin, 1970) to the west and the New Hartford quadrangle to the north. Triassic faulting has been subtracted. The thrusts shown here in the Torrington quadrangle are my own interpretation based on detailed reconnaissance work with Hatch (Hatch and Stanley, 1974). These thrusts are probably Middle to Late Ordovician in age (Taconic) and may well connect with those described by Norton $(1971,1975)$ along the eastern side of the Berkshire anticlinorium.

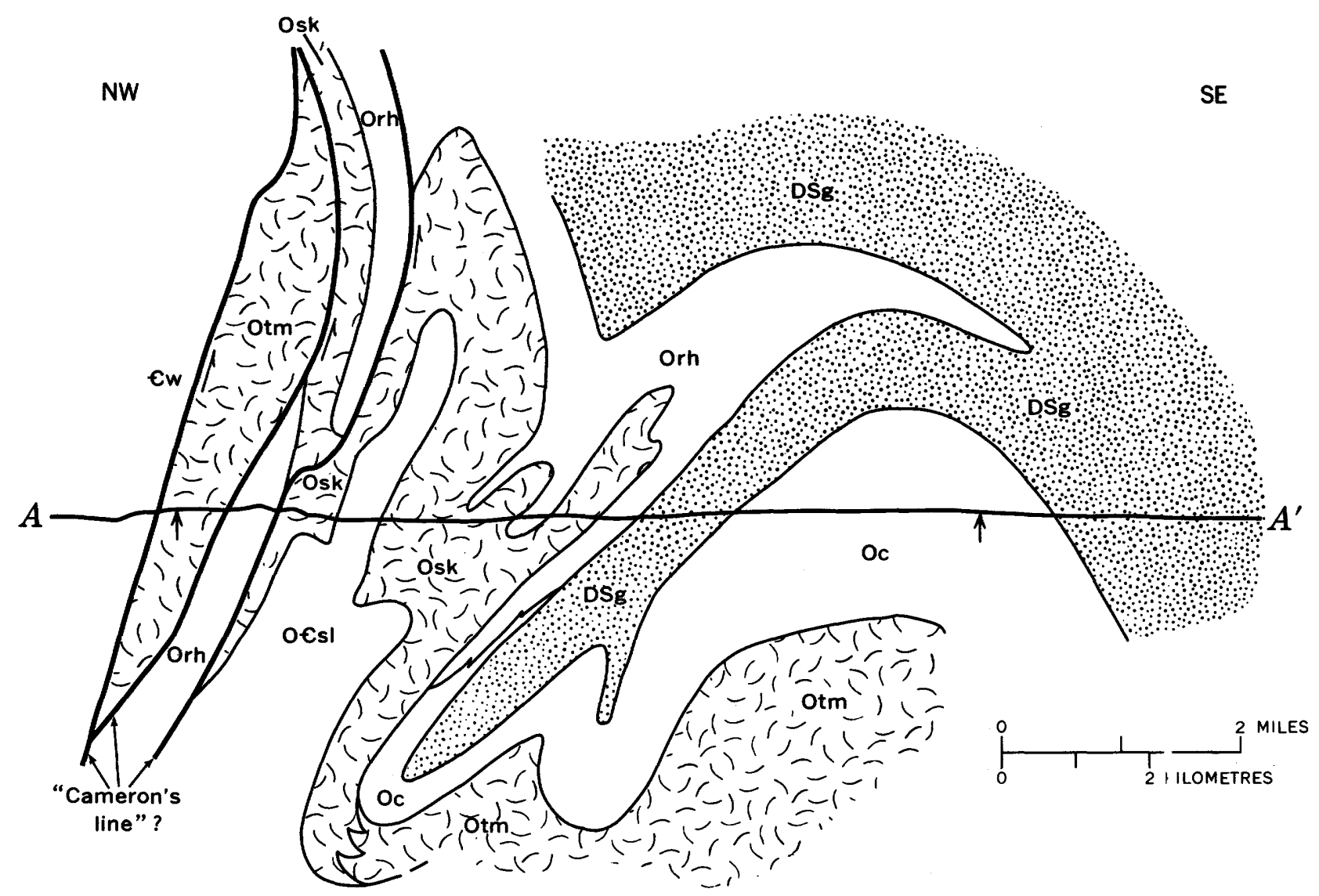

FIGURE 72.-Profile section of the Collinsville area with the effects of Triassic faulting subtracted. Geologic information projected from the New Hartford quadrangle to the north is based on independent mapping and reconnaissance by the author. Line $A-A^{\prime}$ is located on figures 73 and 74 . Vertical arrow near $A$ is located on the Torrington-Collinsville boundary, and the arrow near $A^{\prime}$ is on the Collinsville-Avon boundary. 
Two generations of minor folds were recognized throughout the Collinsville quadrangle. In some places in the isoclinal folds west of the domes the configuration of deformed bedding suggests a third but older set of folds. Because schist forms a major part of the section in much of the quadrangle, evidence for this third generation is very obscure and largely oblierated.

\section{AXIAL-SURFACE MAPS}

$F_{2}$ folds. $-F_{2}$ minor folds have a penetrative axialsurface schistosity and are identical in style to the $F_{2}$ folds in the Blandford-Woronoco area. This schistosity, which is the dominant planar structure in this quadrangle, has been traced northward to the Blandford area where it is the schistosity of $\mathrm{F}_{2}$.

Forty-six axial surfaces of $\mathrm{F}_{2}$ folds are plotted on figure 73. These surfaces are parallel to the calculated axial surfaces of the isoclinal folds between the domes and the belt of Slashers Ledges Formation (O€sl, fig. 73; Stanley, 1964, fig. 79) and also parallel to the isoclinal folds in the syncline of Devonian and Silurian rocks just northwest of the Collinsville and Bristol domes (DSg, fig. 73). These folds are therefore coeval. In the domes the data are less abundant, but the axial surfaces of $F_{2}$ folds generally conform to the shape of the domes (Stanley, 1964, figs. 12 and 13).

The dominant schistosity in Collinsville is folded by the domes, by the synform between the domes, and by the folds northwest of the belt of Slashers Ledges Formation.

$F_{s}$ folds. - Minor folds of this generation are identical in style to the crenulate folds of $F_{3}$ in Massachusetts. In Collinsville they deform the axial schistosity of $F_{2}$ and generally possess a crenulate or slip cleavage. A spaced schistosity is only developed in the synform between the Collinsville and Bristol domes. Here the complete transition from crenulate cleavage to spaced schistosity is well displayed as the synform is traced northwestward from its southeastern end. The axial surfaces of 210 folds from all the schistose rocks of the quadrangle are plotted in figure 74. The orientation of poles to axial surfaces and hinges are shown in Stanley (1964, figs. 15,19 , and 20) and are not repeated here. The axial surfaces generally trend northwest, dip at moderate to steep angles southwest, and do not appear to be systematically deformed as they are to the north in Massachusetts. The small cleavage flexure along the north-central border and the gentle undulation in the western part of the quadrangle (fig. 74) are not considered to be sufficient evidence for a younger generation of folds.
$\mathrm{F}_{3}$ folds are parallel to the calculated axial surface of the synform between the Collinsville and Bristol domes, the antiformal hinge at the north end of the Bristol dome, and the folds in the northwestern part of the quadrangle. They are all considered to be time equivalent in a structural sense. $F_{3}$ folds in Collinsville are correlated to $F_{3}$ folds in the Blandford-Woronoco area because they involve rocks as young as the Goshen Formation, they are stylistically identical in the same rock types, and they are coeval with major synforms either between or adjacent to the domes of both areas.

\section{STRUCTURAL EVOLUTION}

The structural evolution in Collinsville is very similar to the one discussed for the BlandfordWoronoco area. Both generations of folds were developed during Acadian deformation when the Devonian to Cambrian section was deformed into isoclinal folds and then redeformed by the Collinsville and Bristol domes in $\mathrm{F}_{3}$ time.

\section{NEWTOWN QUADRANGLE, WESTERN CONNECTICUT}

The metamorphic geology in the Newtown quadrangle includes rocks of presumed Middle Ordovician through Cambrian age that appear to be a part of a system of east-facing nappes extending southeastward into the belt of Ordovician and Cambrian rocks surrounded by Devonian and Silurian rocks (fig. 62). Intrusive bodies of Newtown Gneiss of Crowley (1968), granite gneiss, and Brookfield Diorite Gneiss as used by Rogers and others (1956) all contain the regional schistosity and hence predate the principal deformational episodes of the area. Triassic rocks underlie the northeastern corner and are bounded by faults of the same age that interrupt the map continuity in the metamorphic rocks (figs. 75 and 76). The eastern part of figures 75 and 76 is in the Southbury quadrangle, recently mapped by Robert Scott (1974).

Two generations of minor folds are recognized throughout the Newtown area. Locally, however, kink folds are well developed and constitute a still younger generation. The dominant minor folds are part of two larger systems that are superimposed on an even older fold, which is outlined by the amphibolite and calc-silicate in figures 75 and 76. Minor folds belonging to these older folds have not been recognized and were probably totally obliterated by the intense deformation of $\mathrm{F}_{2}$ time.

\section{AXIAL-SURFACE MAPS}

$F_{2}$ folds.-Minor folds of the $\mathrm{F}_{2}$ generation are identical in style to the folds of $\mathrm{F}_{2}$ in the Blandford- 


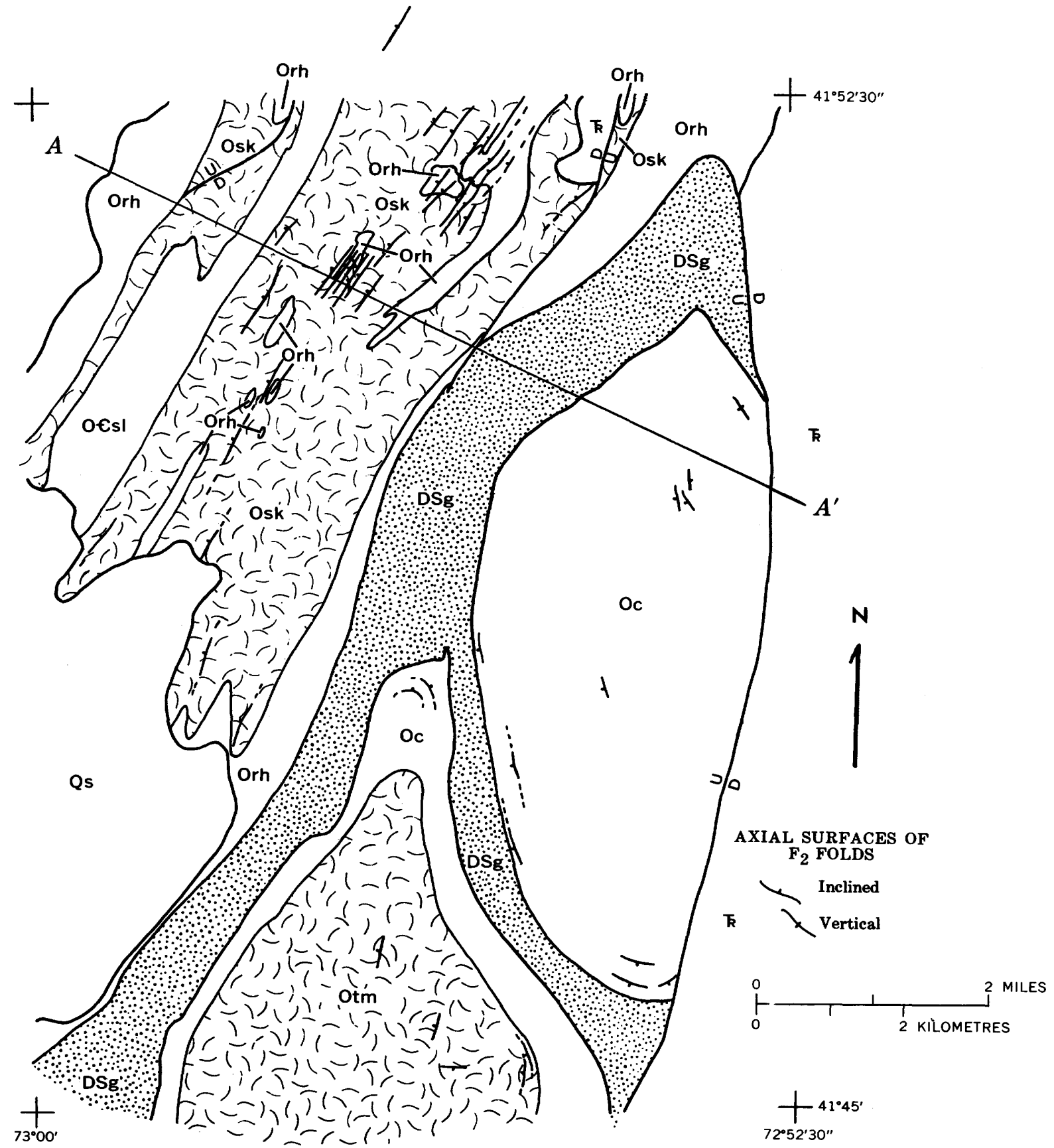

FIgURE 73.-Geologic map of the Collinsville quadrangle showing axial surfaces of $\mathrm{F}_{2}$ folds. Stratigraphic units and symbols are listed in table 1; also, surficial material of Quaternary age (Qs) and undifferentiated Triassic sedimentary rocks ( $\pi$ ). Section $A-A^{\prime}$ is shown in figure 72.

Woronoco area. Their axial surfaces are marked by a penetrative schistosity that can be traced northward to Collinsville. The folds are commonly isoclinal and are reclined, the axis generally paralleling the gentle dip direction of the axial surface (fig. 77, diagrams $A$ and $B$ ).

The axial surfaces of 127 folds, which are most abundant and best preserved in the center of the quadrangle, are plotted in figure 75. Here they clearly cut across the geometric axial surface of a redeformed fold outlined by the amphibolite and calc-silicate. Although this fold is highly contorted, the axial surface trace appears to trend eastward through a series of synforms and antiforms having axial surfaces parallel to those of the $F_{2}$ folds. Clearly, evidence for the two generations can be 


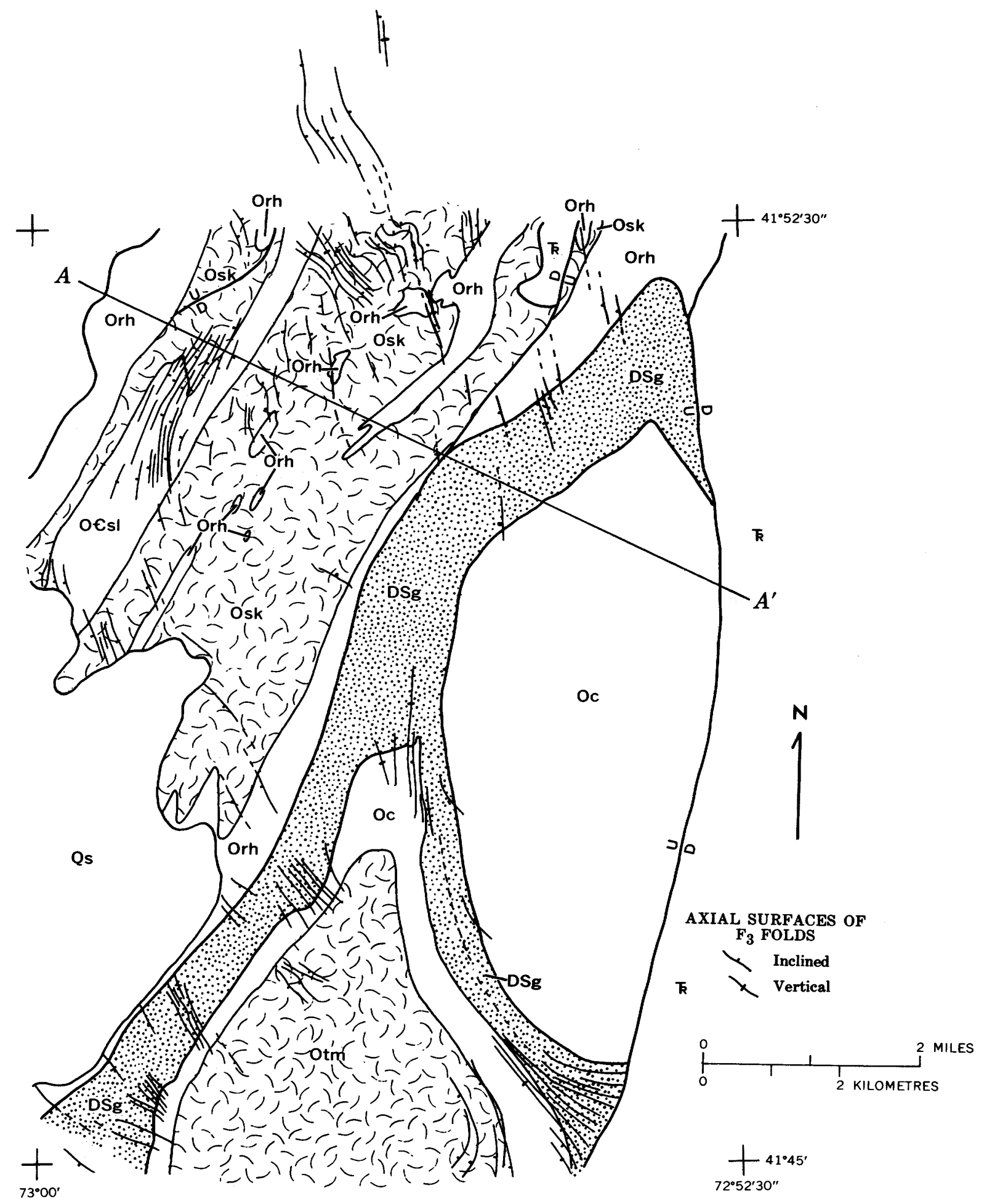

FIGURE 74.-Geologic map of the Collinsville quadrangle showing axial surfaces of $F_{3}$ folds. Stratigraphic units and symbols are listed in table 1; also, surficial material of Quaternary age (Qs) and undifferentiated Triassic sedimentary rocks ( $)$. Section $\mathbf{A}-\mathbf{A}^{\prime}$ is shown in figure 72 . 


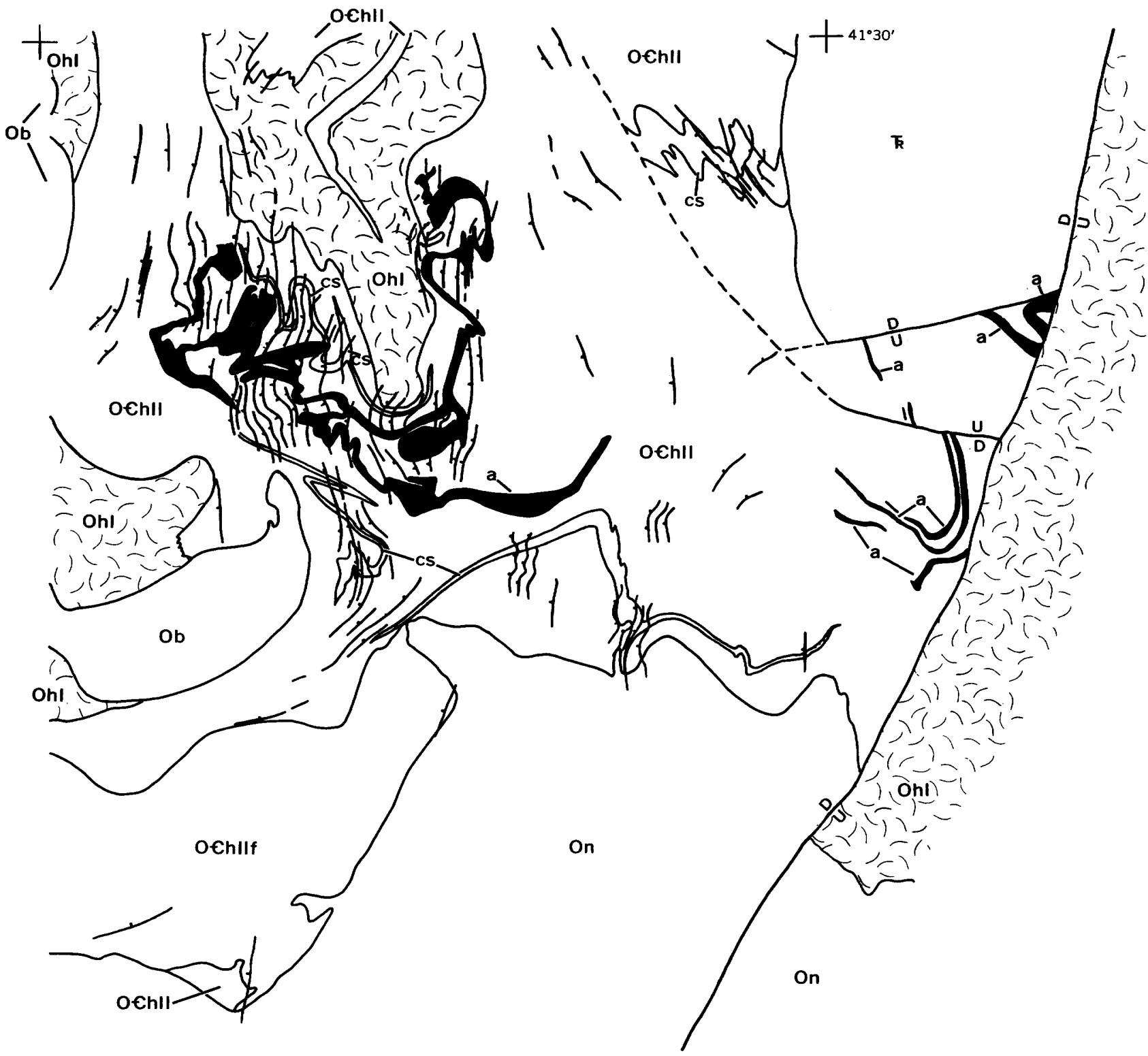

$+$

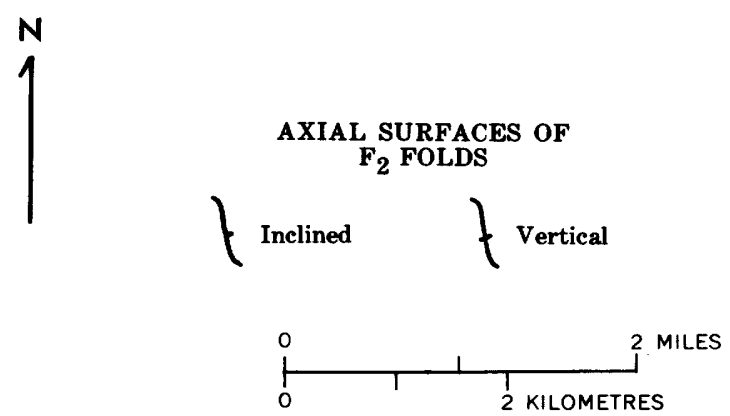

FIGURE 75.-Geologic map of the Newton quadrangle showing axial surfaces of $F_{2}$ folds. Stratigraphic units and symbols are listed in table 1; also, undifferentiated Triassic sedimentary rocks ( $)$, amphibolite (a), and calc-silicate (cs). Area east of long $73^{\circ} 15^{\prime}$ E. mapped by Robert Scott (written commun., 1972). 


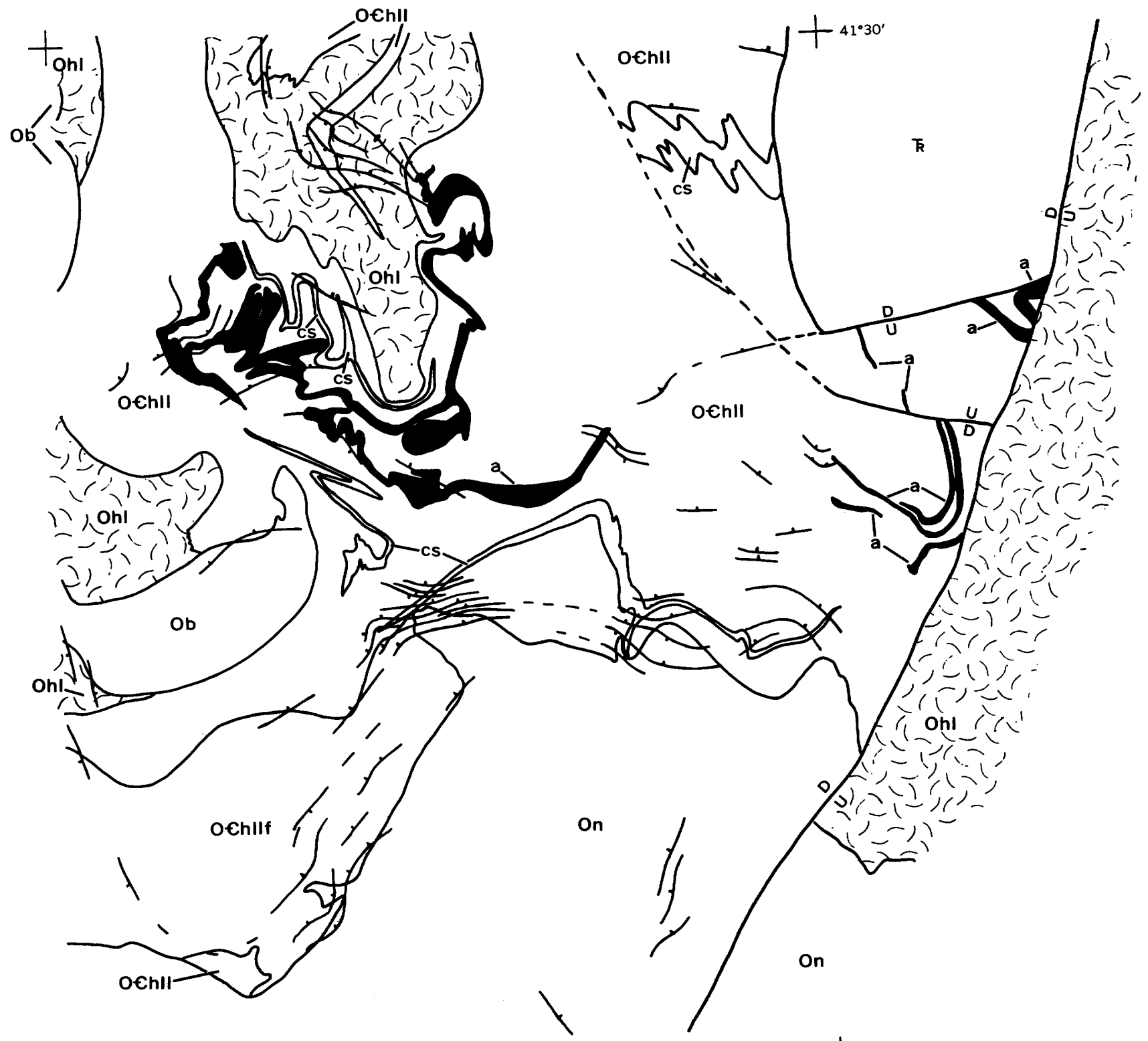

$\mathrm{T}_{73^{\circ} 22^{\prime} 30^{\prime \prime}}$

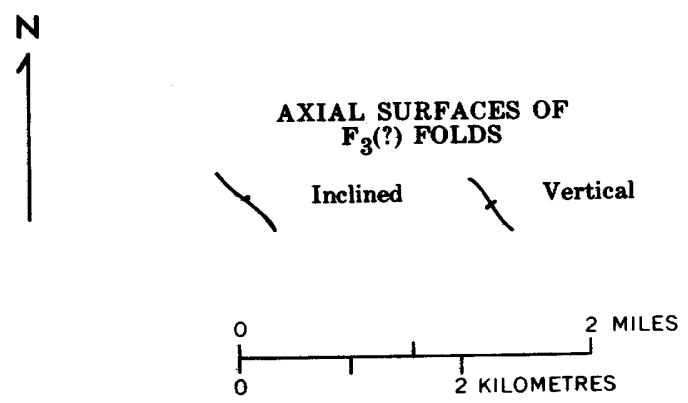

FIGURE 76.-Geologic map of the Newtown quadrangle showing axial surfaces of $F_{3}($ ?) folds. Stratigraphic units and symbols are listed in table 1 ; also, undifferentiated Triassic sedimentary rocks ( $\overline{\text { ) }}$, amphibolite (a), and calc-silicate (CS). Area east of long $73^{\circ} 15^{\prime}$ E. mapped by Robert Scott (written ommun., 1970). 


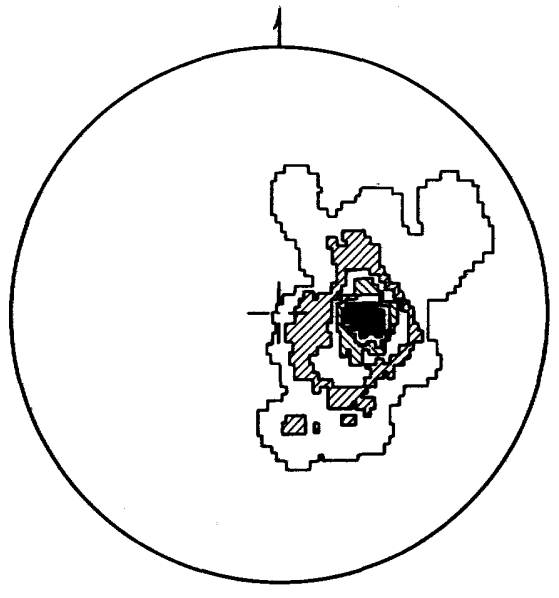

$A$

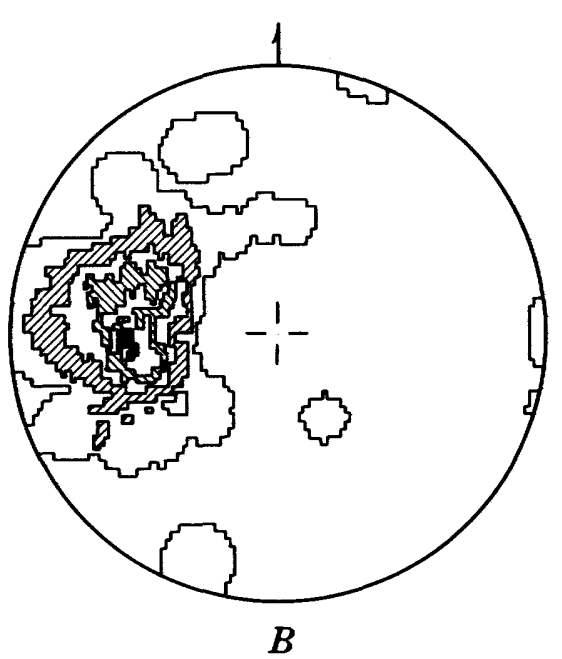

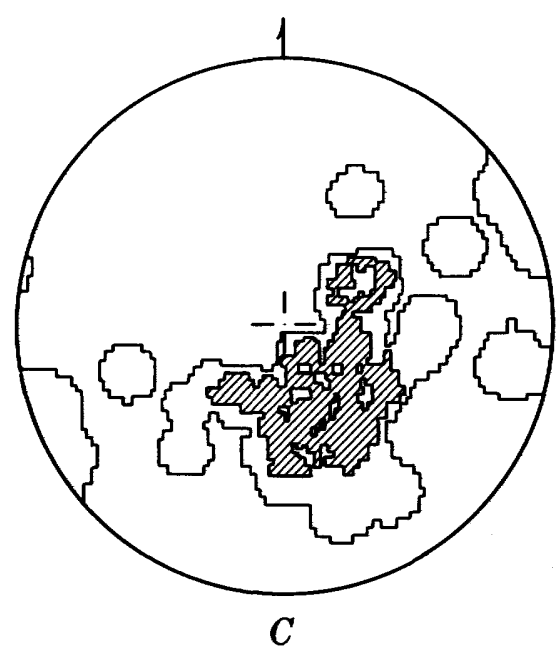

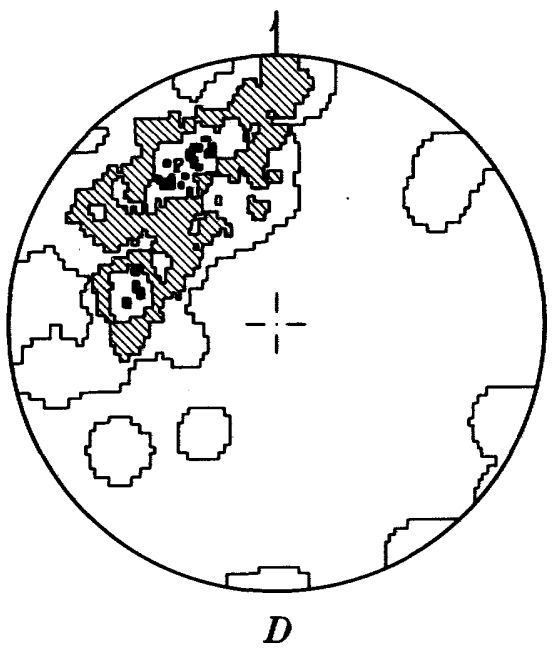

FIGURE 77.-Lower hemisphere equal-area projections of $\mathrm{F}_{2}(A, B)$ and $\mathrm{F}_{3}(?)(C, D)$ folds in the Newton quadrangle. Diagram $A$ contains 107 axial surfaces to $F_{2}$ folds. Diagram $B$ contains $99 \mathrm{~F}_{2}$ fold axes. Contour intervals for $A$ and $B$ are 1.0, 4.0, 8.0, 12.0, 16.0, and 18.0 percent per 1 percent area. Diagram $C$ contains 65 axial surfaces to $F_{3}($ ?) folds. Contour intervals are 1.0, 4.0, and 9.0 percent per 1 percent area. Diagram $D$ contains $64 F_{s}($ ?) fold axes. Contour intervals are 1.0, 4.0, 9.0, and 12.0 percent per 1 percent area. Plane of projections is horizontal with north indicated by arrow.

seen along the limbs of the major fold where the axial surface of $F_{2}$ cut across some of the folds and parallel the calculated axial surfaces of others.

The schistosity of $F_{2}$ in the Newtown area has been traced eastward into the Devonian and Silurian section. The $F_{2}$ folds in Newtown are correlated with those of Collinsville and those of $F_{2}$ in the Blandford-Woronoco area. Consequently, the fold outlined by the ar.phibolite and calc-silicate in the central part of the Newtown quadrangle (fig. 75) may well be conten poraneous with $F_{1}$ in southwestern Massachusetts and hence Taconic in age. If this age assignment is correct, then this is one of the largest Taconic folds recognized in the areas discussed in this chapter. This observation is entirely consistent with regional evidence indicating an increase in Acadian deformation eastward from the classical areas of the Taconic allochthon along the western border of figure 1 (Norton, 1975; Hatch, 1975; Ratcliffe, and Harwood, 1975). Therefore, an older Taconic fabric would be more easily recognized west of the belt of domes where the Newtown area is situated.

$F_{s}$ folds.-Minor folds of the $F_{3}($ ? $)$ generation are scattered but are most abundant in the central part of the Newtown area. All of these folds are somewhat open in profile and deform the regional schis- 
tosity. Axial-surface cleavage was not observed in any of the folds. Furthermore, only a few crenulate folds were developed in the schistose rocks. Therefore these folds are somewhat unlike the $\mathrm{F}_{3}$ folds of Collinsville or Blandford. Although younger than $F_{2}$, their age is still in doubt.

The geometric axial surfaces of $88 \mathrm{~F}_{3}($ ?) folds are plotted in figure 76. The corresponding fold axes and poles to axial surfaces are shown in diagrams $C$ and $D$ of figure 77 . In general the axial surfaces trend westward and are apparently related to the open antiforms and synforms marked by the axial surfaces of $\mathrm{F}_{2}$ folds (compare fig. 75 and fig. 76).

The strongly discordant trends in the southern part of the area may be due either to subsequent deformation or to the simple fact that more than one fold generation has been grouped together. The latter explanation seems more likely, since the formation contacts and the older axial surfaces change trend far less than do the axial surfaces of this generation.

\section{STRUCTURAL EVOLUTION}

The structural history in Newtown involves four generations of folds, two of which are fairly widespread as minor structures. The large superposed fold of amphibolite and calc-silicate apparently was first folded in the Taconic orogeny. During the Acadian orogeny $F_{2}$ folds with a penetrative schistosity formed as part of a larger east-facing system of nappes, involving rocks of Devonian and Silurian age. This schistosity was subsequently deformed by $F_{3}($ ?) folds, possibly during the waning stages of Acadian deformation. Scattered kink folds were then formed and may be associated with Triassic faulting, although a late Paleozoic time is also possible.

\section{REGIONAL CORRELATION}

In the foregoing pages I have described the deformaticnal histories of three study areas in the southweste $n$ part of New England. In Figures 78 and 79 I have attempted to correlate the various events between the areas and also to correlate these events with the sequence of events described by Hatch (1975), the event discussed by Osberg (1975), and the sequence of events discussed by Dieterich $(1968 \mathrm{a}, \mathrm{b})$. The principles of regional correaltion are discussed under Method of Analyses.

Throughout the eastern part of figure 79, an older fabric is recognized in the pre-Silurian rocks. In western Massachusetts this is expressed as a generation of minor folds ( $F_{1}$ and Stage I of fig. 78) cut by penetrative regional schistosity. Recognizable major folds are few in number. To the south along the gneiss domes of western Connecticut, the older fabric is largely obscured by intense Acadian deformation. Remnants of an older schistosity are preserved in porphyroblasts and in the hinge zones of folds in pre-Silurian rocks (Dieterich, 1968a). Complex bedding patterns on the limbs of $F_{2}$ folds in these rocks are also supporting evidence of this Taconic fabric. Farther west in Newtown, away from the domes, the Taconic deformation may be represented by the major east-west fold cut by the regional schistosity. This fold may be part of a still larger system of folds generally unrecognized in the central part of western Connecticut.

The $\mathrm{F}_{2}$ in the Blandford-Woronoco area is part of a regionally persistent system of isoclinal east-facing folds which are vertical to moderately inclined to the west in Massachusetts and which become severely deformed as they are traced southward into Connecticut. Because these folds involve Devonian and Silurian rocks, they are Acadian in age. In all the areas studied, the regional schistosity forms the axial surface of $F_{2}$ minor folds. This schistosity is deformed to varying degrees by younger folds throughout this region, but it is only transposed to a younger schistosity in the tight synclines of $F_{3}$ age between the domes. This younger schistosity can easily be confused with the regional schistosity of $\mathrm{F}_{2}$ unless careful attention is given to the geology. The penetrative schistosity of $F_{2}$ is, therefore, an excellent datum in most areas west of the domes for working out the age relationships of older or younger folds (fig. 79). The $F_{2}$ is by far the most persistent generation of all those in this belt and its axial surfaces provide insight into a heterogeneous strain field of regional magnitude.

Regional correlation of $F_{3}$ folds is more difficult, since it has been shown in the Blandford-Woronoco area that in places they are identical in style to $\mathrm{F}_{4}$ folds. Furthermore, $F_{3}$ folds change orientation and strain level fairly rapidly within a relatively small area. Within the belt of gneiss domes, however, $\mathbf{F}_{3}$ folds are coeval with major synforms of Devonian and Silurian rocks that separate or border the domes. The folds are correlated on this basis in figures 78 and 79 , although they may have originated at slightly different times within this structural event because the domes may not have developed at the same time in a strict sense.

In the Newtown area, $F_{3}($ ?) folds trend westward at a high angle to the $F_{3}$ axial surfaces in the Devonian and Silurian rocks (fig. 79) described by Dieterich (1968a). The age of this eastern set of 


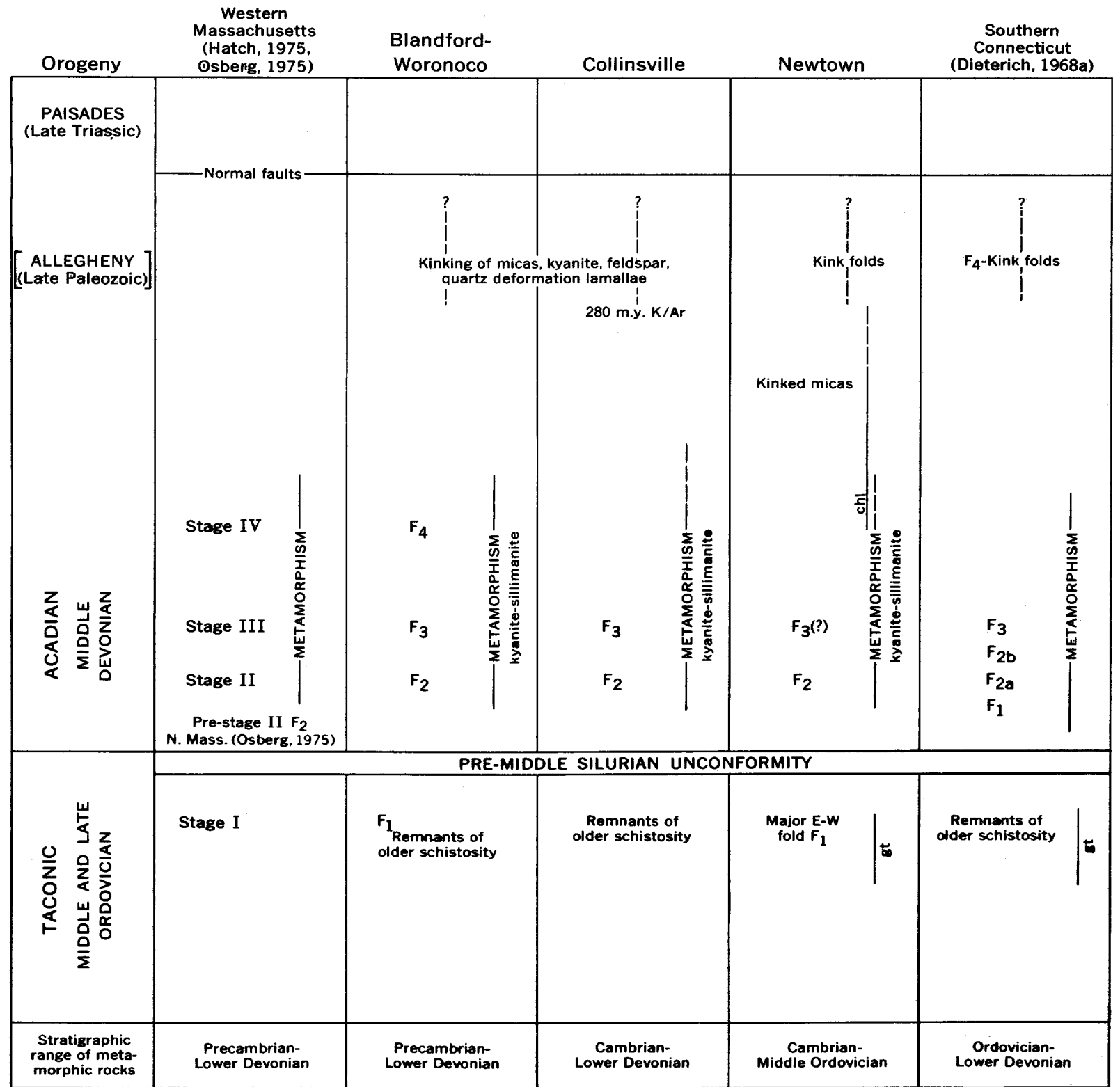

Figure 78.-Correlation chart of fold generations from western Massachusetts and western Connecticut. Abbreviations : ky, kyanite; sill, sillimanite; chl, chlorite; gt, garnet.

folds is known with more confidence, because they are coeval with a major northwest-trending syncline just south of the Waterbury dome. Although the age of $F_{3}$ (?) folds in Newtown is doubtful, they are tentatively considered to be younger than those to the east, since they appear to parallel the westtrending axial surface of a broad, synformal flexure of Devonian and Silurian rocks in a narrow syncline directly east of Newtown (fig. 79). This flexure appears to deform $F_{3}$ to the east.

The $F_{4}$ folds directly superposed on $F_{3}$ have only been recognized in the Blandford-Woronoco area and appear to be absent to the south of that area.
Although the $F_{3}$ (?) folds in Newtown may indeed be younger than $F_{3}$ along the domes, there is no evidence that they are correlative with $F_{4}$ in the Blandford-Woronoco area.

To the north in western Massachusetts the $F_{4}$ folds are stylistically and spatially similar to stage IV folds of Hatch (1975); axial surfaces of which are vertical and trend northward, parallel to those in the Blandford-Woronoco area (fig. 70, diagram $A$ ). The $F_{4}$ folds are prevalent in western Massachusetts, where the gneiss domes are at a deeper structural level and are absent or unrecognized as such throughout the eastern part of western Con- 

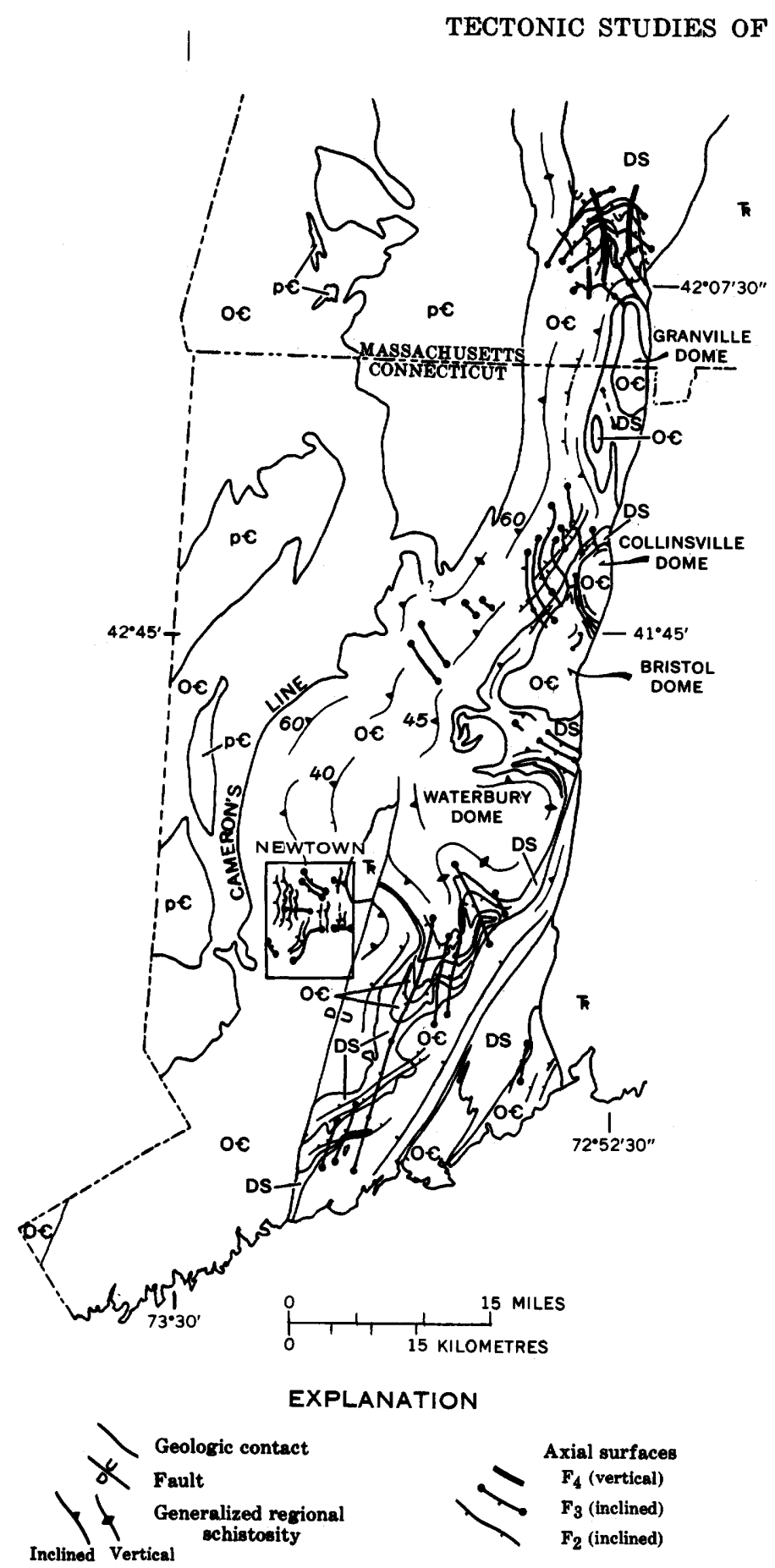

FIGURE 79.-Generalized geologic map of southwestern Massachusetts and western Connecticut showing the orientation of the regional schistosity and the axial surfaces of $F_{2}, F_{3}$, and $F_{4}$. These surfaces are approximations of the strain field of each fold generation. $F_{2}$ is the most extensive geographically and represents a high but uniform level of strain. $F_{3}$ is best developed in structural depressions and synforms between gneiss domes. $F_{4}$ is restricted and far less intense than the older generations. Refer to figure 62 for explanation of letter symbols.

necticut, where the gneiss domes are at a higher structural level and are well expressed.

Scattered in the eugeosyn linal rocks of western New England are late-stage kink folds in rocks and minerals. In most examples, these structures are postmetamorphic and appear more abundant near Triassic faults, which suggests a Triassic age. In the Newtown area, however, chlorite replaces biotite along the deformed limb of kinked biotite. This lowgrade recrystallization postdating the deformation of the mica may represent a late Acadian or even Allegheny event (ICaldwell, 1972).

Osberg (1975) presents evidence for a large-scale nappe in the Devonian rocks in the northern part of Massachusetts. This structure predates the isoclinal folds of $\mathrm{F}_{2}$ and, as yet, has not been recognized to the south in Massachusetts. In the southern part of western Connecticut, Dieterich (1968a) recognized an early generation of folds cut by the regional schistosity of his $F_{2}$ folds (figs. 78 and 79). This early fold system is based on the map pattern of the Taconic unconformity (fig. 79) and involves the pre-Silurian section. Minor folds with axialsurface cleavage and associated lineations were not recognized. It appears, therefore that a regionally significant system of folds developed in Acadian time, prior to the formation of the isoclinal folds and nappes with their regionally persistent schistosity. Evidence for this fold generation is totally absent in the Blandford-Woronoco and Collinsville areas; this may be due to the intensity of subsequent deformation which has largely obliterated graded beds and coeval minor folds.

The chronology between metamorphism and deformation in western Massachusetts is well documented by Hatch (1975) and Norton (1975). Additional information is found in the Newtown area, where clean chlorite porphyroblasts cut the regional schistosity throughout much of this area, and is also found in deformed limbs of kinked biotites (Caldwell, 1972). This type of evidence suggests that a young, low-grade metamorphism was superimposed on a preexisting higher grade terrain. This event may have occurred in late Paleozoic time during the Allegheny orogeny.

\section{ACKNOWLEDGMENTS}

Many of the ideas in this paper have evolved from numerous discussions with colleagues in New England and elsewhere. I would especially like to acknowledge the intellectual stimulation provided through lively discussions $w$ th J. Rodgers, E. Hansen, P. H. Osberg, and L. M Hall. My collaborative 
work with N. L. Hatch, Jr., in recent years has been very fruitful; the geology in the Devonian and Silurian rocks of figures 63,67 , and 69 was largely mapped by Hatch and S. F. Clark, Jr. Discussions with D. S. Harwood, J. C. Hepburn, S. A. Norton, and $\mathrm{N}$. M. Ratcliffe have been very rewarding. $\mathrm{N}$. L. Hatch, Jr., D. S. Harwood, P. H. Osberg, B. L. Doolan, and K. Rouleau have critically reviewed the manuscript.

Financial support for work in Connecticut was provided by the Connecticut Geological and Natural History Survey, Joe Webb Peoples, Director. Work in Massachusetts was supported by a National Science Foundation Postdoctoral Fellowship (19621964), a National Science Foundation Institutional grant funded through the University of Vermont (1964-1966), and the U.S. Geological Survey in cooperation with the Massachusetts Department of Public Works (1968-1974). Funds for photographic reproduction and typing were provided by the Department of Geology, University of Vermont.

\section{REFERENCES CITED}

Caldwell, K. G., 1972, Petrographic and chemical analysis of rocks from the Newton, area, Connecticut: M.S. thesis, Univ. Vermont, Burlington, Vt., 80 p.

Crowley, W. P., 1968, The bedrock geology of the Long Hill and Bridgeport quadrangles, with maps: Connecticut Geol. and Nat. History Survey Quad. Rept. 24, 81 p.

Dieterich, J. H., 1968a, Sequence and mechanies of folding in the area of New Haven, Naugatuck, and Westport, Connecticut: Ph. D. thesis, Yale Univ., New Haven, Conn., $153 \mathrm{p}$.

1968b, Multiple folding in western Connecticut-A reinterpretation of structure in the New Haven-NaugatuckWestport area, New England Intercollegiate Geol. Conf., 60th Ann. Mtg., Oct. 35-27, 1968, Guidebook for field trips in Connecticut: Connecticut Geol. and Nat. History Survey, Guidebook no. 2, p. D2-1-13.

1969, Origin of cleavage in folded rocks: Am. Jour. Sci., v. 267 ,no. 2 , p. $155-165$.

Fletcher, R. C., 1972, Application of a mathematical model to the emplacement of mantled gneiss domes: Am. Jour. Sci., v. 272 , no. 3 , p. 197-216.

Hatch, N L., Jr., 1968, Isoclinal folding indicated by primary sedimentary structures in western Massachusetts, in Geological Survey Research 1968: U.S. Geol. Survey Prof. Paper 600-D, p. D108-D114.

- 1975, Tectonic, metamorphic, and intrusive history of part of the east side of the Berkshire massif, Massachusetts in Tectonic studies of the Berkshire massif, western Massachusetts, Connecticut, and Vermont: U.S. Geol. Survey Prof. Paper 888-D, p. 51-62.

Hatch, N. L., Jr., and Stanley, R. S., 1970, Stratigraphic continuity and facies changes in formations of early paleo- zoic age in western Massachusetts and tentative correlations with Connecticut [abs.]: Geol. Soc. America, Abs. with Programs, v. 2, no. 1, p. 23-24.

1973, Some suggested stratigraphic relations in part of southwestern New England: U.S. Geol. Survey Bull. 1380, 83 p. [1974].

Martin, C. W., 1970, The bedrock geology of the Torrington quadrangle, Connecticut: Connecticut Geol. and Nat. History Survey Quad. Rept. 25, $53 \mathrm{p}$.

Norton, S. A., 1971, Possible thrust faults between Lower Cambrian and Precambrian rocks, east edge of the Berkshire highlands, western Massachusetts [abs.]: Geol. Soc. America, Abs. with Programs, v. 3, no. 1, p. 46.

1975, Chronology of Paleozoic tectonic and thermal metamorphic events in Ordovician, Cambrian, and Precambrian rocks at the north end of the Berkshire massif, Massachusetts, in Tectonic studies of the Berkshire massif, western Massachusetts, Conneticut, and Vermont: U.S. Geol. Survey Prof. Paper 888-B, p. 21-31.

Osberg, P. H., 1971, Bulk strain in rocks determined from fold axes [abs.]: Geol. Soc. America, Abs. with Programs, v. 3, no. 7, p. 665-666.

1972, Recumbent folding of the Goshen and Waits River Formations, western Massachusetts [abs.]: Geol. Soc. America, Abs. with Programs, v. 4, no. 1, p. 37-38. 1975, Recumbent folding of the Goshen and Waits River Formations, western Massachusetts, in Tectonic studies of the Berkshire massif, western Massachusetts, Connecticut, and Vermont: U.S. Geol. Survey Prof. Paper 888-E, p. 63-68.

Rodgers, John, Gates, R. M., and Rosenfeld, J.L., 1956, Preliminary geological map of Connecticut: Connecticut Geol. and Nat. History Survey.

Ratcliffe, N. M., and Harwood, D. S., 1975, Blastomylonites associated with recumbent folds and overthrusts at the western edge of the Berkshire massif, Connecticut and Massachusetts-A preliminary report, in Tectonic studies of the Berkshire massif, western Massachusetts, Connecticut, and Vermont: U.S. Geol. Survey Prof. Paper 888-A, p. 1-19.

Scott, R. B., 1974, The bedrock geology of the Southbury quadrangle: Connecticut Geol. and Nat. History Survey Quad. Rept. 30, 63 p.

Stanley, R. S., 1964, The bedrock of the Collinsville quadrangle: Connecticut Geol. and Nat. History Survey Quad. Rept. 16, 99 p.

__ 1967, Geometry and age relations of some minor folds and their relation to the Woronoco nappe, Blandford and Woronoco quadrangles, Massachusetts, in New England Intercollegiate Geol. Conf., 59th Ann. Mtg. Oct. 13-15, Guidebook for field trips in the Connecticut Valley of Massachusetts : Amherst, Mass., p. 49-60.

1968, Metamorphic geology of the Collinsville area, in New England Intercollegiate Geol. Conf. 60th Ann. Mtg., Oct. 25-27, 1968, Guidebook for field trips in Connecticut: Connecticut Geol. and Nat. History Survey, Guidebook no. 2, p. D4-1-17.

1972, Time and space relationships of structures associated with the domes of southwestern Massachusetts and western Connecticut [abs.]: Geol. Soc. America, Abs. with Programs, v. 4, no. 1, p. 46. 
Minor Folds and Derived Orientations

of Strain in the East Flank of the

Berkshire Massif, Massachusetts

By PHILIP H. OSBERG

TECTONIC STUDIES OF THE BERKSHIRE MASSIF, WESTERN MASSACHUSETTS, CONNECTICUT, AND VERMONT

GEOLOGICAL SURVEY PROFESIONAL PAPER 888-G

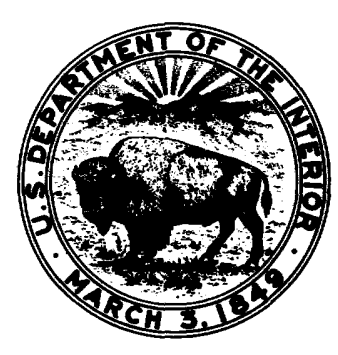





\section{CONTENTS}

Abstract

General statement

Method

Strain associated with $\mathrm{F}_{2}$ and $\mathrm{F}_{3}$

\section{ILLUSTRATIONS}

FIGURE 80. Sketch map showing multiple deformation establishing sequential development of folds

81. Triaxial ellipsoid showing principal sections and circular sections and their perpendiculars -..-

82. Construction to determine greatest and least diameters in any section of a triaxial ellipsoid

83. Paired planes containing normal to folded surface and disposed symmetrically about the fold axis - -

84. Triple intersections of three pairs of symmetrically disposed planes

85. Stereogram showing potential solutions to the positions of normals to the circular sections of the strain ellipsoid from three differently oriented fold axes

86. Regional tectonic map showing orientations of the axial surfaces for $F_{2}$ and $F_{3}$ folds, east flank Berkshire massif

87. Diagram showing orientation of strain for $F_{2}$ at West Cummington, Mass.

88. Diagram showing orientation of strain for $\mathbf{F}_{3}$ at Cummington, Mass.

89. Graph showing relationship between limb ratio and $a$, where $a$ is the angle between $\lambda$ and the folded surface measured in a plane perpendicular to the fold axis 



\title{
MINOR FOLDS AND DERIVED ORIENTATIONS OF STRAIN IN THE EAST FLANK OF THE BERKSHIRE MASSIF, MASSACHUSET'TS
}

\author{
By Philip H. Osberg ${ }^{1}$
}

\begin{abstract}
Minor folds in the Goshen Formation and in pre-Goshen rocks in the east side of the Berkshire massif have been sequenced $\left(F_{1}-F_{4}\right.$, exclusive of those related to doming) using the criteria of superposition. Minor folds belonging to the several deformational events have orientations that vary both locally and regionally.

Using a method analogous to the Biot-Fresnel construction of optical crystallography, the orientations of the strain ellipsoids were derived for $F_{2}$ and $F_{3}$ and were found to be distinctively different for each fold generation, even at a single outcrop. By this method, the orientation of the strain ellipsoid was determined from the attitudes of three differently oriented surfaces and their included fold axes. The normals to the circular sections of the strain ellipsoid were constrained to be in a pair of planes symmetrically arranged with respect to the fold axis and including the normal to the folded surface. The intersection of three sets of such paired planes constructed on three differently oriented surfaces gave a possible solution to the positions of the normals to the circular sections. Several solutions were determined, and these were found to cluster into two concentrations on a stereograph; the centers of gravity of the clustered solutions is a good approximation to the true positions of the normals to the circular sections The $\lambda_{1}$ and $\lambda_{3}$ lie in the plane of the normals to the circular sections and bisect the angles between them. The $\lambda_{2}$ is perpendicular to the $\lambda_{1}-\lambda_{3}$ plane. The axial surfaces of the folds lie approximately in the $\lambda_{1}-\lambda_{2}$ plane and thus serve to differentiate between $\lambda_{1}$ and $\lambda_{3}$.

The orientation of a minor fold depends on the attitude of the folded surface and the orientation of the strain ellipsoid. The asymmetry of a fold depends in large measure on the angle between the perpendicular to the fold axis in the surface being folded and the $\lambda_{3}$ direction.

Because axial surfaces of minor folds belonging to the same deformational event approximately parallel the $\lambda_{1}-\lambda_{2}$ symmetry plane of the strain ellipsoid, regional changes in orientation of the strain ellipsoid can be easily monitored. The distinctive orientations for the strain ellipsoids associated with at least $F_{2}$ and $F_{3}$ are surprisingly uniform over large areas. Successive strain increments each have unique orientations and are episodic.
\end{abstract}

\footnotetext{
${ }^{1}$ University of Maine, Orono, Maine.
}

\section{GENERAL STATEMENT}

A myriad of minor folds in the Goshen Formation and in pre-Goshen rocks of western Massachusetts and contiguous areas have a diversity of styles, sizes, and attitudes. Yet, as described in the preceding chapters (Hepburn, 1975; Hatch, 1975; and Osberg, 1975), these structural features have been sequenced by applying the rule of superpositionyounger structural features deform older ones. At many exposures a minor fold clearly deforms another, indicating the relative age of both. In figure 80 , three minor folds mutually interfere. The oldest is isoclinal and is folded by the fold whose axial trace trends northeast; this fold, in turn, is deformed by the fold whose axial trace trends southeast, thereby establishing the sequential development of the three folds. Observations of this sort compiled over a large area have led to the following sequence (in order of decreasing age) of minor folds (exclusive of those related to local doming in the Goshen and Waits River Formations) :

$F_{1}$, large recumbent folds;

$F_{2}$, smaller but still large upright isoclinal folds;

$\mathrm{F}_{3}$, still smaller asymmetric folds with northeast trends; and

$F_{4}$, still smaller asymmetric folds with north trends.

This chapter presents a geometric method for determining the strain orientation manifested by minor folds of diverse orientations but of a single deformation. Following the description of the method, the strain orientations are derived for $F_{2}$ and $F_{3}$. The strain orientation is then used to show (1) that minor folds with different tectonic styles in the Goshen Formation and in pre-Goshen rocks were formed during the same deformation, (2) that 


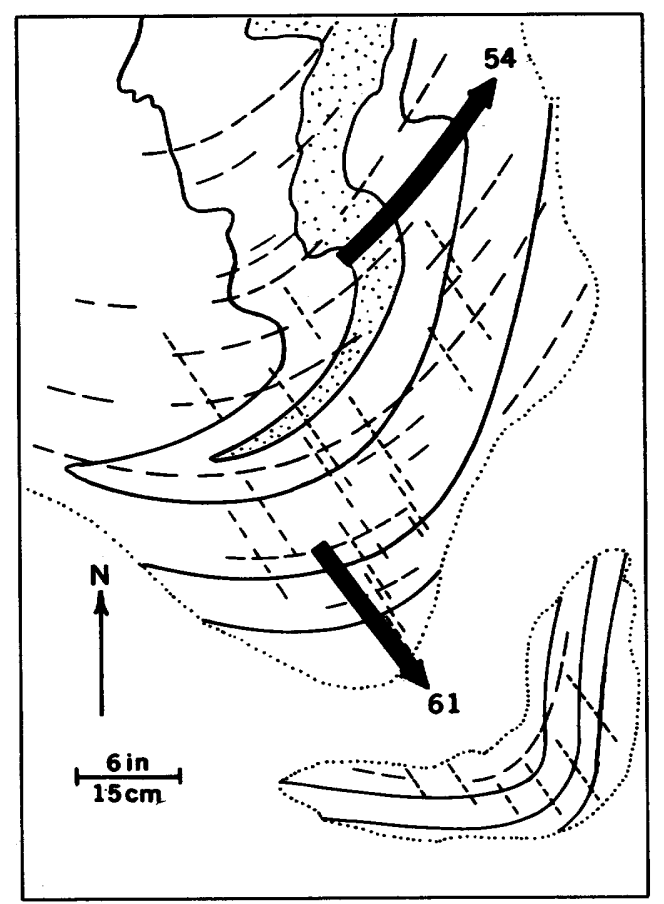

Figure 80.-Sketch map of multiple deformation establishing sequential development of folds. Stippled pattern represents core of earliest fold. Degrees of plunge given for two later folds. Modified from Osberg and others, 1971.

the strain orientation defined by folds formed during a single deformation is uniform over large areas, and (3) that the deformation was episodic. In addition, the asymmetry of a fold is related to the attitudes of the strain ellipsoid and of the surface being folded.

\section{METHOD}

The strain investigated in this chapter is defined as that part of the finite strain realized in a single deformation; it describes the mean strain in a volume of rock of several cubic metres. In the general case the strain can be represented by a triaxial ellipsoid with major axes $2 \sqrt{\lambda_{3}}<2 \sqrt{\lambda_{2}}<\sqrt{\lambda_{1}}$ (fig. 81). Such an ellipsoid has two circular sections intersecting in $\lambda_{2}$.

The orientation of the strain ellipsoid can be derived using a method analogous to the Biot-Fresnel construction of optical mineralogy. The Biot-Fresnel construction is a geometric method for determining the orientations of the greatest and least diameters of an ellipse generated by the intersection of a plane and a triaxial ellipsoid. In this method the orientation of the surface is specified relative to that of the triaxial ellipsoid. Planes constructed so as to contain the normal to the specified surface, $\mathrm{ON}$, and the normals to the circular sections of the triaxial ellipsoid, $O A$ and $O B$, intersect the specified surface along $O C$ and $O D$ (fig. 82). The bisector of angle COD is one direction sought and the perpendicular to it in the specified surface is the other. (See Shubnikov, 1960, p. 86.)

Let us now apply the Biot-Fresnel construction to strain in rocks. The triaxial ellipsoid of optical crystallography is, of course, geometrically analogous to the strain ellipsoid. Assuming that the orientation of the strain ellipsoid is specified, what fold orientation should develop on a surface with a given attitude? The two dimensional strain on the surface is described by an ellipse having axes $\lambda^{\prime}{ }_{1}$ and $\lambda^{\prime}{ }_{3}$ (fig. 82). If $\sqrt{\lambda_{3}^{\prime}}$ is significantly less than $\sqrt{\lambda^{\prime}{ }_{2}}$, a fold axis may be contained in the surface and such a fold axis will be found to parallel $\lambda^{\prime}{ }_{1}$. This relationship has been previously suggested by Ramberg (1959, p. 115).

For geological purposes, the analogy to the BiotFresnel construction must be approached in reverse - start with the fold axes contained in surfaces and work to the positions of the normals to the circular sections of the strain ellipsoid; once their positions are located, the orientation of the strain ellipsoid can be determined.

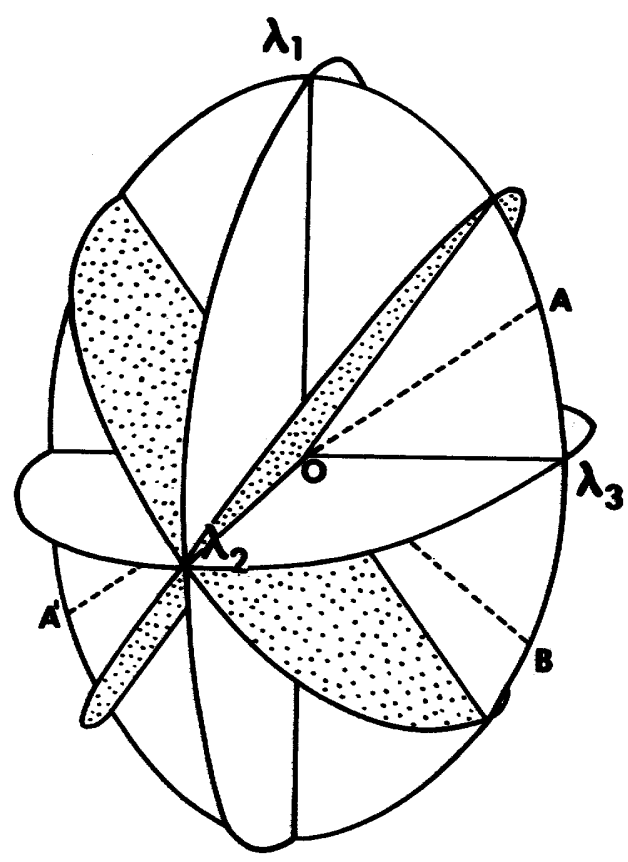

Frgure 81.-Triaxial ellipsoid showing the three principal sections; also, the circular sections (stippled) and their perpendiculars, $\mathrm{OA}$ and $\mathrm{OB}$. 


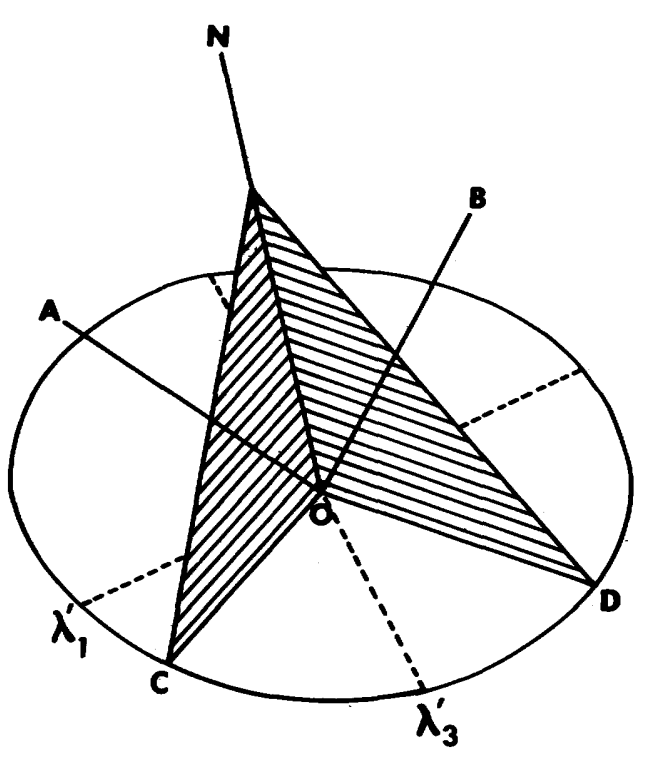

FIGURE 82.-Construction to determine the greatest and least diameters in any section of a triaxial ellipsoid. $O N$ is the normal to the specified surface, and $O A$ and $O B$ are the normals to the circular sections of the triaxial ellipsoid. The planes containing $O N, O A$ and $O N, O B$ intersect the specified surface along $\mathrm{OC}$ and $\mathrm{OD}$, respectively.

Thus, given a fold axis (Of on fig. 83) located in a surface of known orientation (stippled on fig. 83), the normals to the circular sections of the strain ellipsoid can be located in some pair of planes that include the normal to the folded surface $(\mathrm{ON})$ and that are symmetrically disposed relative to the fold axis, such as pairs +1 and $-1,+2$ and -2 , and so forth. Sets of planes can be similarly constructed about fold axes in two additional folded surfaces with differing orientations. In each case the normals to the circular sections of the strain ellipsoid lie in two planes symmetrically disposed about the fold axis and containing the normal to the folded surface.

If the orientations of the three folded surfaces, their contained fold axes, and the three sets of paired, symmetrically disposed planes are superimposed, two triple intersections of the symmetrically disposed planes indicate possible positions of the normals to the circular sections of the strain ellipsoid. In figure 84 all of the constructed planes except those making the triple intersections are omitted for the sake of simplicity. This construction does not give a unique solution, but the geometric constraints are such that all possible solutions lie within $15^{\circ}$ or $20^{\circ}$ of the true positions of the normals to the circular sections of the strain

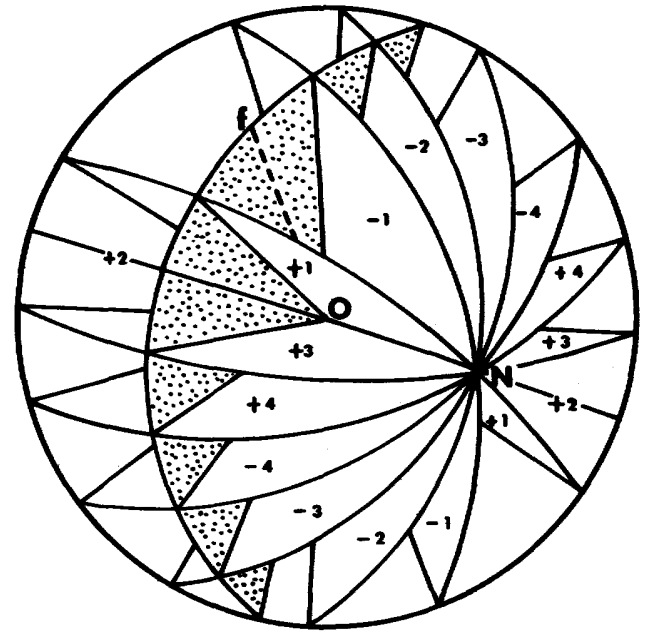

Figure 83.-Paired planes, +1 and -1 , and so forth, contain the normal to the folded surface, $O N$, and are disposed symmetrically about the fold axis, Of, which lies within the folded surface (stippled). Upper hemisphere.

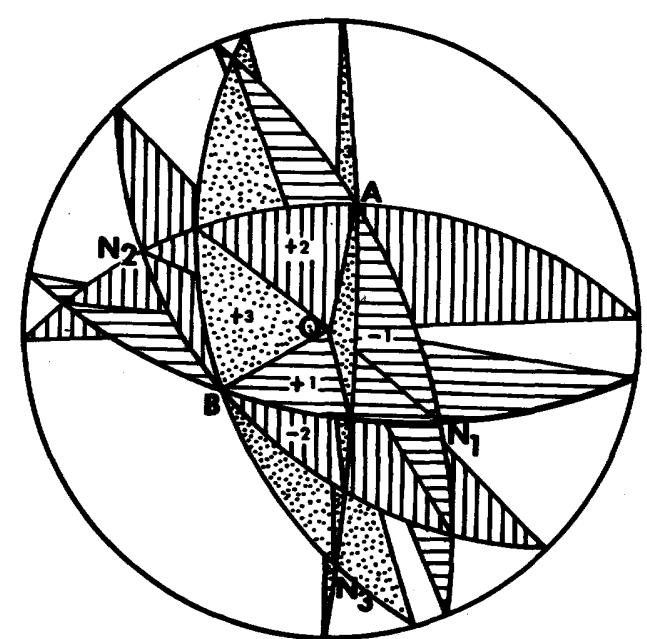

Figure 84.-Triple intersections of three pairs of symmetrically disposed planes. OA and $\mathrm{OB}$ are triple intersections. $\mathrm{ON}_{1}, \mathrm{ON}_{2}$, and $\mathrm{ON}_{3}$ are normals to folded surfaces. $+1,-2,+3$ and $-1,+2,-3$ are labels to planes symmetrically disposed with reference to the fold axes. Upper hemisphere.

ellipsoid. Figure 85 is a stereogram showing the position of the normals to the circular sections that were used to generate fold axes on three differently oriented surfaces. Using the orientation of the fold axes and the method described above, potential solutions to the positions of the normals to the circular sections were tried. The solid circles indicate valid solutions, and the open circles represent invalid solutions. Thus the true positions of the normals to the circular sections (circles with 
crosses on fig. 85) are close to the centers of gravity of the concentrations representing valid solutions. The two normals to the circular sections of the strain ellipsoid (OA and $\mathrm{OB}$, fig. 81) define the $\lambda_{1}-\lambda_{3}$ symmetry plane. The $\lambda_{2}$ is perpendicular to this plane. The $\lambda_{1}$ and $\lambda_{3}$ bisect the angles between the normals to the circular sections, and $\lambda_{1}$ and $\lambda_{3}$ may be distinguished by plotting the axes of the minor folds, for these lie approximately in the $\lambda_{1}-\lambda_{2}$ plane.

In practice the planes containing the normals to the circular sections and the surface in question are drawn at $5^{\circ}$ or $10^{\circ}$ intervals on a 12-inch stereonet. Those drawn on one side of a fold axis are numbered positively and those constructed on the other side are numbered negatively. Each set of planes associated with a fold axis is colored (a different color for each set), and the three sets are superimposed on a light table. An intersection of three planes is sought, for example, planes labeled $+1,-2,+3$. If this represents a possible position of a normal to the circular section, a second triple intersection should occur at a point where planes labeled -1 , $+2,-3$ intersect. If an intersection does not occur, the pair of positions is abandoned, and other pairs are investigated, until two intersections bearing symmetrical labels are found. These two points are possible positions of the normals to the circular

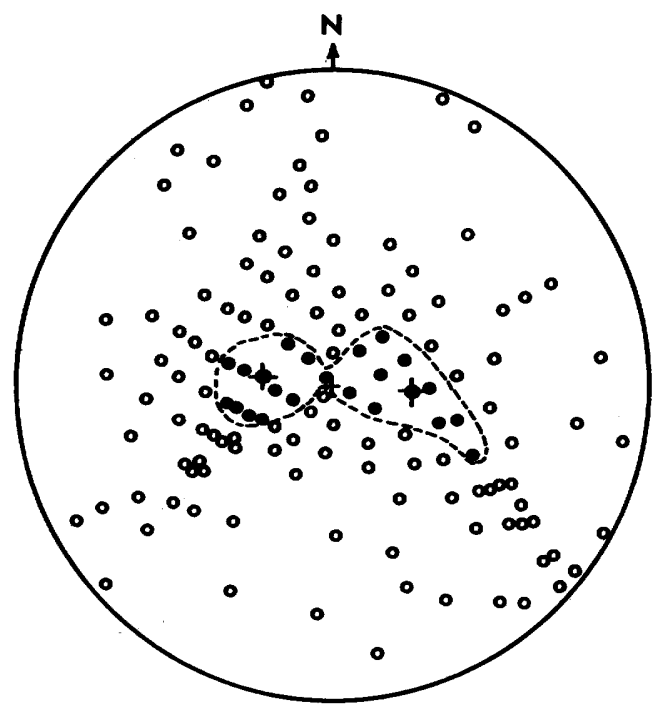

FIGURE 85.--Stereogram showing potential solutions to the positions of the normals to the circular sections of the strain ellipsoid from three differently oriented fold axes. Solid circles with crosses indicate true position of the normals to the circular sections. Solid circles are successful solutions; open circles are unsuccessful solutions. Lower hemisphere. sections. The procedure is repeated until a significant number of valid solutions are found; the centers of gravity of the resulting clusters give a good approximation for the locations of the normals to the circular sections.

Using this method the folded surface is that which is tangential to the hinges of several folds belonging to the generation under study. Ramberg (1959, p. $124,131)$ has shown that if an initially folded layer is rotated during strain, the folds continuously readjust to the new positions of the surface. Consequently, the original orientation of the surface before folding is unimportant, but it is necessary that the folds are a function of the local mean strain and of the orientation of the surface on which they developed. Folds of earlier deformations are preserved because the mean strains of later deformations do not parallel those producing the earlier folds. Surfaces that can be used in the construction include bedding, dikes, veins, and schistosity.

This method is feasible only where cylindrical folds belonging to the same generation are present in at least three folded surfaces having different orientations. The folds in any one folded surface are collinear, but, when compared with those in other folded surfaces of different orientation, they are noncollinear. The case in which folds are collinear from folded surface to folded surface cannot be treated by this method.

\section{STRAIN ASSOCIATED WITH $F_{2}$ AND F $_{3}$}

The $F_{2}$ in the Goshen Formation is recognized as large isoclinal upright folds having nearly horizontal axes. Because the axes are collinear from fold to fold, they cannot be manipulated by the method previously described. On the basis of their sequential development, $F_{2}$ in the Goshen Formation have been equated to folds in pre-Goshen rocks that have quite different styles; the latter folds are isoclinal to open and have a diversity of plunges. The $F_{2}$ in both the Goshen Formation and the pre-Goshen rocks are similar folds.

By the method described above, the orientation of the strain ellipsoid was determined from three differently plunging folds in pre-Goshen rocks at West Cummington, Mass. (fig. 86). The orientation of the strain ellipsoid so derived is shown in figure 87; its orientation is: $\lambda_{1}=79^{\circ}$ N. $6^{\circ}$ E., $\lambda_{2}=22^{\circ} \mathrm{S}$. $7^{\circ}$ W., $\lambda_{3}=1^{\circ}$ S. $83^{\circ} \mathrm{E}$.

In order to determine if the folds at West Cummington were correctly correlated with $F_{2}$ in the Goshen Formation, the orientation of the strain ellipsoid determined at West Cumington was used to 


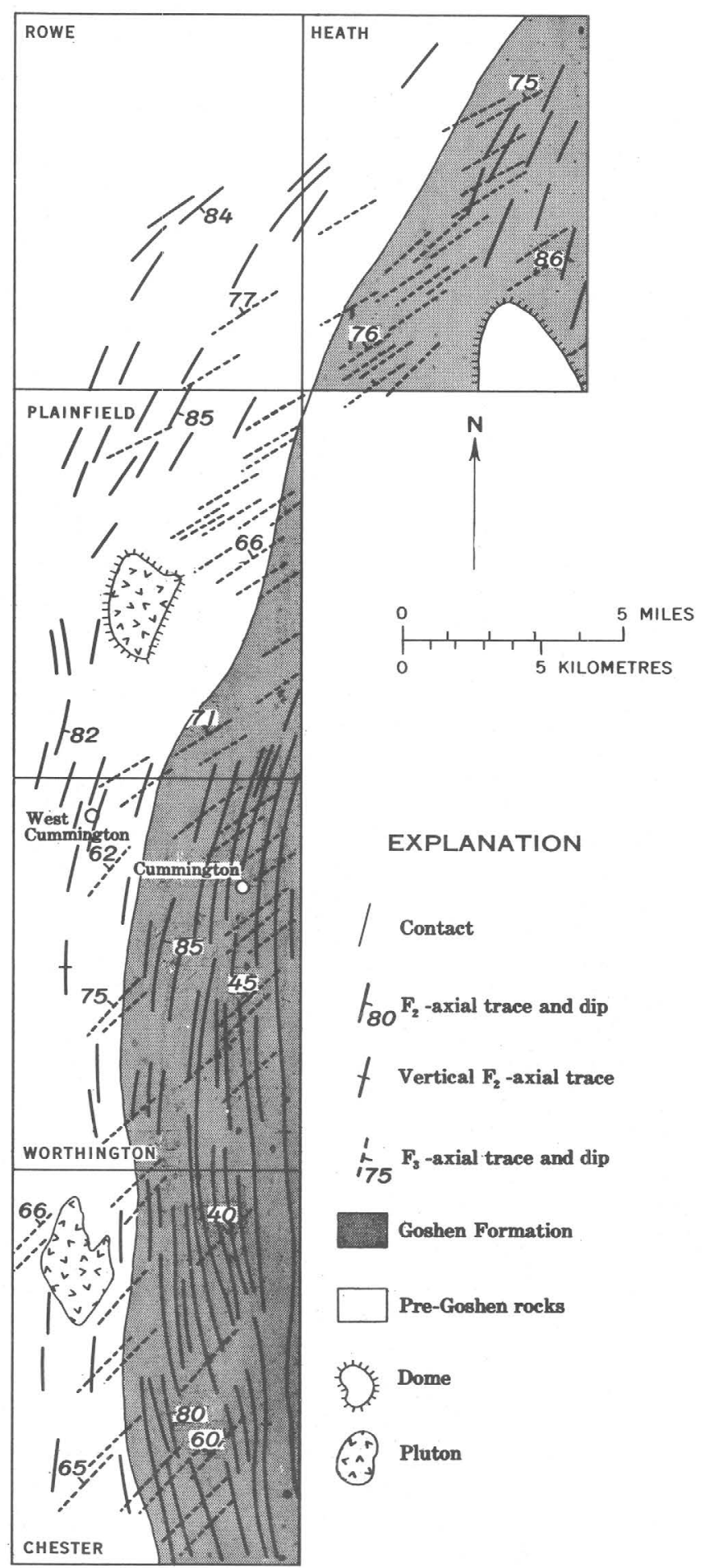

Figure 86.-Regional tectonic map showing orientations of the axial surfaces for $F_{2}$ and $F_{3}$ folds in quadrangles on the east flank of the Berkshire massif. The geographic locations of Cummington and West Cummington, Mass. are indicated. Data from the Heath (Hatch and Hartshorn, 1968), the Rowe (Chidester and others, 1967), the Plainfield (Osberg and others, 1971), the Worthington (Hatch, 1969), and the Chester (Hatch and others, 1970) quadrangle maps.

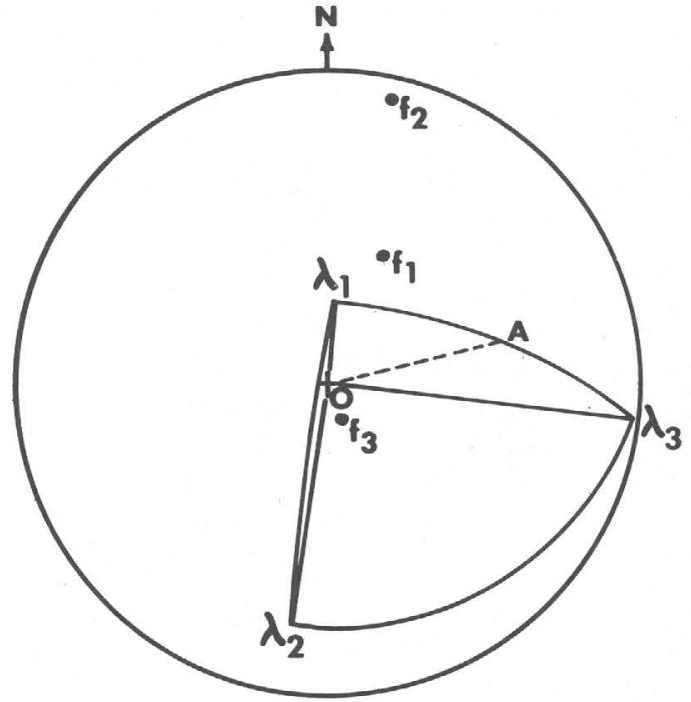

FIGURE 87.-Orientation of strain for $F_{2}$ at West Cummington, Mass. OA is normal to circular section. Symbols $f_{1}, f_{2}$, and $f_{3}$ are axes to folds. Lower hemisphere.

establish a fold axis on the surface folded by what was presumed to be $F_{2}$ at Cummington, Mass. (See figure 86.) If the strain fields of the folds at both localities were the same, the axis so established should parallel the observed $\mathrm{F}_{2}$ axis. The observed plunge of a large $\mathrm{F}_{2}$ is $22^{\circ} \mathrm{N} .3^{\circ} \mathrm{E}$., whereas the plunge predicted by using the strain ellipsoid is $22^{\circ} \mathrm{N} .6^{\circ} \mathrm{E}$. The axes are nearly identical and, considering the distance of correlation, minor inaccuracies of measurement, and the assumptions involved in the method, it can be concluded that the sets of folds at Cummington and West Cummington are correctly correlated.

The strain relationships for $F_{3}$ were also determined at Cummington using small, asymmetrical, approximately similar folds that deform $F_{2}$ at that locality. The resulting orientation of the strain ellipsoid derived using the Biot-Fresnel analogy is shown in figure 88; the orientation is: $\lambda_{1}=37^{\circ} \mathrm{N}$. $21^{\circ}$ E., $\lambda_{2}=38^{\circ} \mathrm{S} .75^{\circ} \mathrm{W}$, and $\lambda_{3}=32^{\circ} \mathrm{S} .40^{\circ} \mathrm{E}$. This strain orientation can generate hypothetical fold axes on the limbs of $\mathrm{F}_{2}$ which are consistent with the local $\mathrm{F}_{3}$.

\section{ASYMMETRY OF MINOR FOLDS}

The asymmetry of minor folds is defined in terms of their limb ratio, which is the ratio of the length of the short limb to the length of the long limb. Observed limb ratios range from $1: 10$ to $1: 1$. At West Cummington the trend and average dip of bedding were measured at four positions around an $\mathrm{F}_{2}$ fold. At each position the limb ratios of smaller 


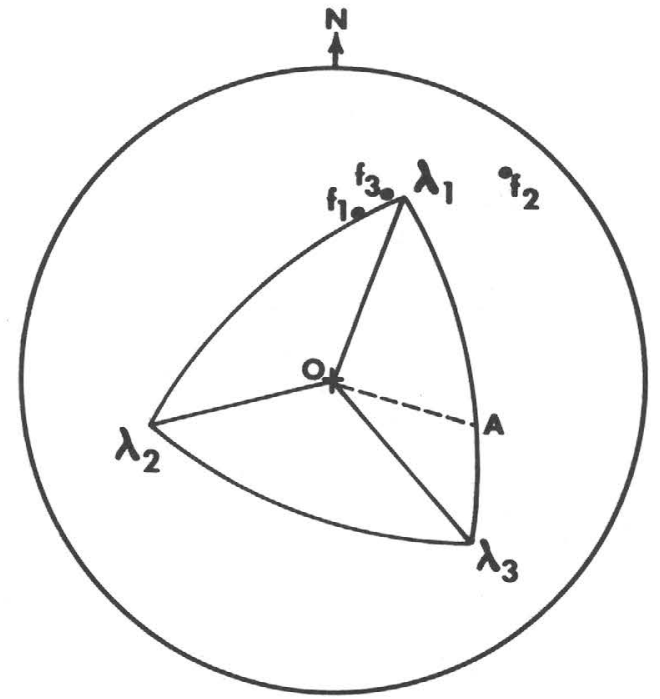

FIGURE 88.-Orientation of strain for $\mathrm{F}_{3}$ at Cummington, Mass. OA is normal to circular section. Symbols $f_{1}, f_{2}$, and $f_{3}$ are fold axes. Lower hemisphere.

folds occurring on the limbs of the larger fold were determined. The angle $a$, the angle between $\lambda_{3}$ of the locally determined strain ellipsoid and the perpendicular to the fold axis in the surface being folded, was calculated. These data are plotted in figure 89 . An inverse relationship apparently exists between the two parameters, angle $a$ and limb ratio; the smaller the angle $a$, the more closely the limb ratio approaches unity. There is, of course, a value of $a$ above which folds do not form. The mechanical properties of the rocks may play an important part in the relationship between the limb ratio and the angle $a$, and the relationship between these parameters will vary accordingly.

\section{REGIONAL CORRELATION OF MINOR FOLDS}

Although it has been possible to determine the orientation of strain attending folding at fortuitous localities, the regional correlation of minor folds presents an additional problem, especially when the strain orientation varies regionally. In determining the orientation of the strain ellipsoid from local sets of folds, it was noted that the diversely oriented axes lie close to the $\lambda_{1}-\lambda_{2}$ plane (figs. 87 and 88). Because the axial surfaces of the folds used in the construction are essentially parallel and the fold axes must lie in the axial surfaces of these folds, the $\lambda_{1}-\lambda_{2}$ plane of the strain ellipsoid is required to parallel approximately the axial surfaces and $\lambda_{3}$ must be approximately perpendicular to the axial surfaces. Thus, a comparison of the orientations of the axial surfaces of the folds is a convenient means

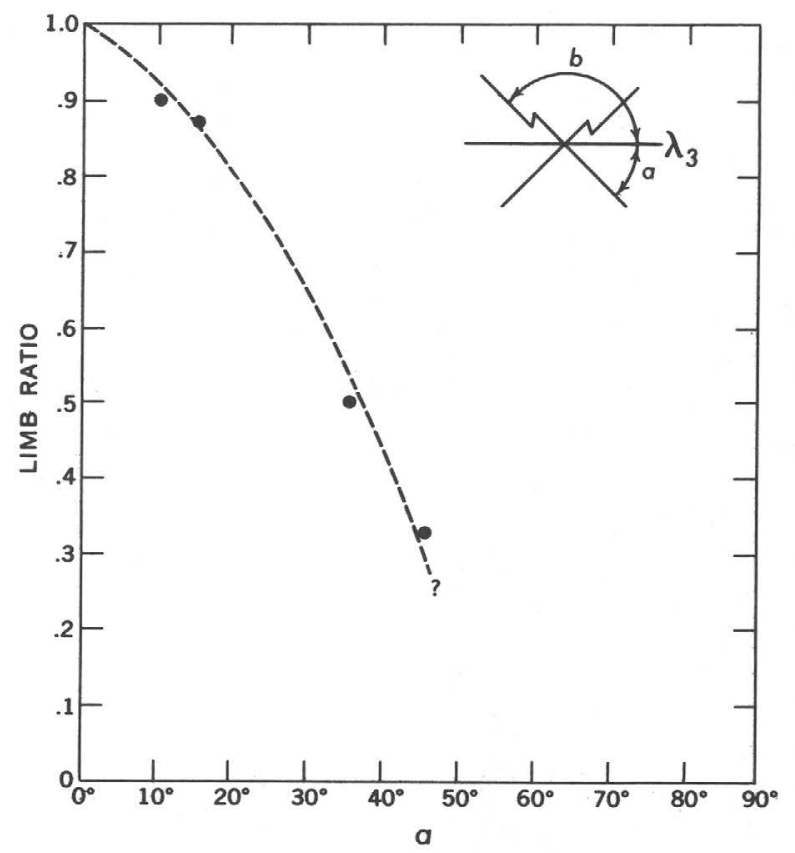

FIGURE 89.-Relationship between limb ratio and $a$, where $a$ is the angle between $\lambda_{3}$ and the folded surface measured in a plane perpendicular to the fold axis. The limb ratios were determined from the smaller folds occurring on the limbs of the $F_{2}$ fold at West Cummington. Inset shows the rotational sense of the fold toward the obtuse angle $b$.

of monitoring the orientation of the strain field regionally.

The traces of axial surfaces of $\mathrm{F}_{2}$ are recorded in figure 86 as discontinuous lines with dips recorded at appropriate places. Folds were assigned to $F_{2}$ by extending orientation data for the axial surfaces outward from the orientations at Cummington. If the orientation of the strain increment varied abruptly with geographic distribution, the orientation could not be extended over a large area. The fact that it can be extended for tens of kilometres indicates that a uniform strain field existed over the region studied.

In like manner the orientation data for $\mathrm{F}_{3}$ axial surfaces were extended outward from Cummington. These axial surfaces are represented by dashed lines along with dips at appropriate places on figure 86 . The data from the quadrangle maps cited in the caption. Although the axial traces have uniform trends, the changes in dip may indicate original differences in strain orientation or may be due to subsequent folding.

It is somewhat surprising that the axial surfaces of $\mathrm{F}_{2}$ are not deformed by $\mathrm{F}_{3}$, and that $\mathrm{F}_{3}$ axial surfaces are not folded by $F_{4}$. The undeformed character, when considered on a regional scale, of the 
axial surfaces results from the relative magnitudes of the strains associated with each deformation, $F_{2}>F_{3}>F_{4}$. If, however, the strain associated with a later fold is greater than that of an earlier fold, the axial surfaces of the earlier folds will be folded, on a regional scale, by the younger folds (See Stanley, 1975). Thus, if mesoscopic folds can be correlated on the basis of stylistic and superposition criteria, and if their axial surfaces do not define a uniform regional orientation, the folds may be assumed to have been deformed by later folds of larger wavelength and amplitude. The axial surfaces of the earlier folds then define the younger fold, but the reference is the attitude of the undeformed axial surfaces, not the horizontal.

\section{EPISODIC CHARACTER OF STRAIN FIELDS}

It is apparent that early strains are not completely obliterated by later strains and that the strain increments inferred from individual sets of folds at any given outcrop are distinctive. Moreover, the orientations of such strain increments vary smoothly within the region, so that distinctive strain increments have significance. Because the strain increments do not represent a continuous or even nearly continuous sequence in the variation of their orientations, they must be regarded as episodic, that is, discrete events in time characterized by boundary conditions on the region, defined by each stress field producing an orientation different from the previous one, that is clearly reorganizable from one event to the next.

\section{CONCLUSIONS}

The following conclusions can be drawn from the above discussion :

1. Minor folds can be sequenced using the law of superposition.

2. Folds belonging to a single deformation are the manifestation of a uniquely oriented strain field.

3. The orientation of a minor fold depends on the attitude of the folded surface and the orientation of the strain field.

4. The asymmetry of a fold depends in large part on the angle between the perpendicular to the fold axis in the surface being folded and the $\lambda_{3}$ direction.

5. The strain increments associated with folds of a given deformation at the time of formation of the folds is uniform over large geographic regions.

6. Successive strain increments each have unique orientations and are episodic.

\section{ACKNOWLEDGMENTS}

The ideas presented in this chapter were developed over twenty years of field study. Most of the primary observations were made while mapping for other purposes, and, therefore, the work was supported indirectly by agencies including: the Office of the State Geologist of Vermont, the Penrose Bequest of the Geological Society of America, the U.S. Geological Survey, the Office of the State Geologist of Maine, and the National Science Foundation. The manuscript was critically reviewed by Raymond Fletcher, D. S. Harwood, N. H. Hatch, Jr., and Robert Simpson; their comments were most helpful and are gratefully acknowledged.

\section{REFERENCES CITED}

Chidester, A. H., Hatch, N. L., Jr., Osberg, P. H., Norton, S. A., and Hartshorn, J. H., 1967, Geologic map of the Rowe quadrangle, Franklin and Berkshire counties, Massachusetts, and Bennington and Windham counties, Vermont: U.S. Geol. Survey Geol. Quad. Map GQ-642.

Hatch, N. L., Jr., 1969, Geologic map of the Worthington quadrangle, Hampshire and Berkshire counties, Massachusetts: U.S. Geol. Survey Geol. Quad. Map GQ-857. 1975, Tectonic, metamorphic, and intrusive history of part of the east side of the Berkshire massif, Massachusetts, in Tectonic studies of the Berkshire massif, western Massachusetts, Connecticut, and Vermont: U.S. Geol. Survey Prof. Paper 888-D, p. 51-62.

Hatch, N. L., Jr., and Hartshorn, J. H., 1968, Geologic map of the Heath quadrangle, Massachusetts-Vermont: U.S. Geol. Survey Geol. Quad. Map GQ-735.

Hatch, N. L., Jr., Norton, S. A., and Clark, R. G., Jr., 1970 , Geologic map of the Chester quadrangle, Hampden and Hampshire counties, Massachusetts: U.S. Geol. Survey Geol. Quad. Map GQ-858.

Hepburn, J. C., 1975, Tectonic and metamorphic chronology of the Devonian and Silurian rocks in the Guilford dome area, southeastern Vermont, in Tectonic studies of the Berkshire massif, western Massachusetts, Connecticut, and Vermont: U.S. Geol. Survey Prof. Paper 888-C, p. 33-49.

Osberg, P. H., Hatch, N. L., Jr., and Norton, S. A., 1971, Geologic map of the Plainfield quadrangle, Franklin, Hampshire, and Berkshire counties, Massachusetts: U.S. Geol. Survey Geol. Quad. Map GQ-877.

Osberg, P. H., 1975, Recumbent folding of the Goshen and Waits River Formations, western Massachusetts, in Tectonic studies of the Berkshire massif, western Massachusetts, Connecticut, and Vermont: U.S. Geol. Survey Prof. Paper 888-E, p. 63-68.

Ramberg, Hans, 1959, Evolution of ptygmatic folding: Norsk Geol. Tidsskr., v. 39, p. 99-152.

Shubnikov, A. V., 1960, Principles of optical crystallography: New York, Consultants Bur., 186 p.

Stanley, R. S., 1975, Time and space relationships of structures associated with the domes of southwestern Massachusetts and western Connecticut, in Tectonic studies of the Berkshire massif, western Massachusetts, Connecticut, and Vermont: U.S. Geol. Survey Prof. Paper 888-F, p. $69-96$. 



\section{INDEX}

Page

Acadian orogeny _..... 27, 30, 46, 52, 61, 86, 93 Adamant pluton -....... 67 Age, deformations _-_.-_... 27

K-Ar, Barre Granite - 67 Middlefield Granite -........ 27, 61

Rb-Sr, Black Mountain Granite --- 43, 46 Middlefield Granite -

Taconic orogeny -.-_- 17, 18

Allegheny orogeny -

Almandine zone, metamorphism -...-- 45

Alum Hill

Ascutney sigmoid - 43

Ashley Falls quadrangle -............ 1,4

Athens dome -... 33

Autochthonous sequence 6

Barnard Volcanic Member _..-_-_...- 35, 44 Barre Granite, K-Ar age -

Barrovian-style metamorphism -- 13, 17, 18, 45 Beartown Mountain Slice (nappe) - 1, 8, 12, 13 Becket quadrangle _................ 23, 24 Benton Fill -...... 4 Biot-Fresnel construction - 98 Biotite .............. 6, 8, 10, 11, 13 lepidoblastic 8 Biotite grade, metamorphism -..-.-.- 57 Biotite zone, metamorphism -...- 45 Black Mountain Granite _......._. 39, 43, 46 Blandford quadrangle -...-.-_-_-- 75 Blastomylonite, defined -......... 4 Brattleboro quadrangle (.......... 38, 44, 64 Brattleboro syncline Bristol dome Bronson Hill anticlinorium - 33 Brookfield Diorite Gneiss _.......... 87

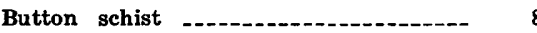

Cameron's line Cambrian - Cambrian rocks _...... 1, 21, 34, 51, 52, 70, 87 Cataclastic rocks - 4, Cataclastic processes, results of -..-- 16 Cheshire quadrangle

Cheshire Quartzite -.......... 1, 6

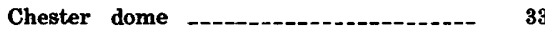

Chester quadrangle .

Chlorite grade, metamorphism -..... 57

Chlorite zone, metamamorphism -...-- 45

Cobble Mountain Formation -- 70, 72, 76, 85

Cobble Mountain Reservoir _..._._...- 75

Collinsville dome 87

Collinsville quadrangle -..._._- 75, 86

Colrain dome

Colrain quadrangle ................. 6

Cram Hill Member - 35

Cummington, Mass. -

Dalton Formation _......... 1, 6, 7, 8, 9, 24 Deerfield River -

Deformation, age --_-_-_- 27 summary -..-- 56

Triassic
Devonian

Page

Devonian rocks _._._._- 33, 34, 46, 51, 52, 61

$67,69,76,84,87$

Dynamothermal metamorphism

-------

East Lee quadrangle _...... 1,8

East Mountain

Egremont quadrangle -

Eugeosynclinal rocks _............ 21, 75, 95

Eugeosynclinal sequence -..-..-..--.-- 51

Fall Brook anticline -_._._._._. 35, 41, 44 Faults, ductile -

Faulting Triassic - -

Feldspar -

Ferrohastingsite -

Garnet -

Garnet, syntectonic -...-.-_. 45

Garnet grade, metamorphism -

Green Mountain anticlinorium _......- 33, 45

Geology, general, summary -...

$21,23,61,69$

Gile Mountain Formation _._. $39,44,67$

Gile Mountain sequence -

Goshen dome -......... 56

Goshen Formation ---- 29, 44, 52, 72, 76, 87, 97

Granville dome -...-........-....... 84

Great Barrington quadrangle

Guilford dome

Guilford dome area, sections -

Heath quadrangle

$54,64,65$

Hoosac Formation

$22,24,26,52$

Hoosac nappe

Hornblende -

Isograds

Kinsman Quartz Monzonite -...-_-_-_ 61 Kyanite grade, metamorphism -.. 51, 57, 75 Kyanite isograd _....................... 23

Lake Buel slice -..-_- 10 Lepidoblastic minerals Littleton Formation

Metamorphism -_._-_ 6, 10,13, 17, 27, 44, 75 almandine zone -................ 45

biotite zone -

chlorite zone ........- 45

dynamothermal

Paleozoic

Microcline -

Microcline perthite

age -

Middlefield thrust zone -

Missisquoi Formation _........... 35, 41, 44

Monterey quadrangle -......- 1

Monument Mountain
Page

Moretr wn Formation

Mount Ida -..-_- 18

Muscovite _..._. 6, 7, 8, 10, 13

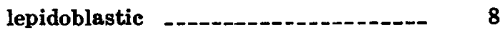

Mylonite, gneiss, defined - 4

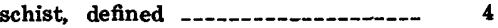

Myogeosynclinal rocks _._. 21

New Hampshire Plutonic Series Neomineralization _................. 6,11 Newtown Gneiss - - 87

Newtown quadrangle ............... 75, 87

North Adams quadrangle -.---_-_------ 23, 26 Northfield Formation

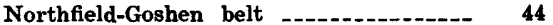

Oligoclase - Ordovician rocks _....... 1, 17, 21, 27, 30, 34 $52,70,76,84,87$

Orthotechonic deformation _....-.-. 18

Otis quadrangle _....... 23

Ottauquechee Formation _........ 52

Paleozoic, metamorphism rocks tectonic events -

Peru quadrangle -...-_..-_..- 23, 24

Pinney Hollow Formation -........ 52

Pittsfield East quadrangle

Plagioclase -

Precambrian gneiss _._._._._._._._. 1, 4, 16 rocks _..._. $1,13,17,21,24,29,33,52,70$

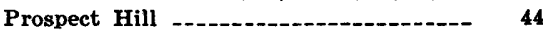

Prospect Hill fold _._._._._._._._._._. 35, 43

Putney Formation _..-_. 39

Putney Volcanics -_- 43

Pyrite

Quartz $6,7,8$

Ray Pond dome -

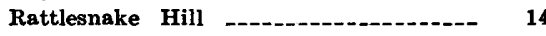

Rattlesnake Mountain _............. 14 Rowe Schist _.

Saxtons River quadrangle -...-...-. 44

Sadawaga dome -...-...........- 33

Sections, Guilford dome area - 38

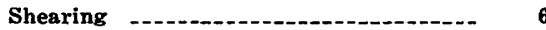

Shelburne Falls dome Sillimanite-grade metamorphism - 13, 18, 51, 75 Sillimanite isograd ................ 23

Silurian, recumbent folding -.......- 67 rocks -...-_ $33,34,46,52,69,76,84,87$ Slashers Ledges Formation -.....-- 87 South Sandisfield quadrangle _...- 1, 15, 17, 18 Standing Pond Volcanics -...-.. 33, 35, 39, 44 State Line quadrangle

Staurolite-grade metamorphism - 13, 51, 57

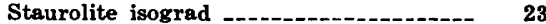

Staurolite-kyanite zone, metamorphism- 45

Stockbridge Formation -.... 4,6 


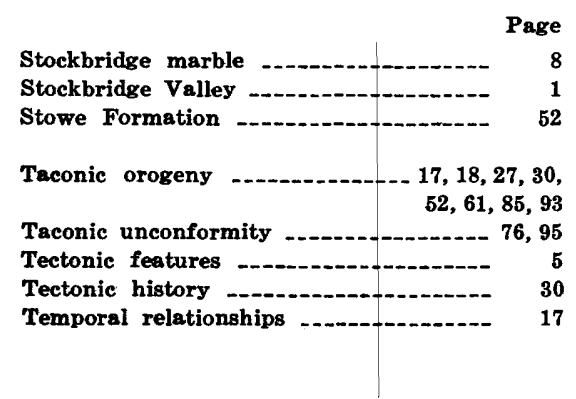

Page

Textures, blastomylonitic

Tourmaline

Triassic deformation -..._-_._.-. 75, 86, 93 faulting -rocks _.

Tyringham Gneiss

Vermont sequence -

Volcanic rocks, Middle Ordovician -.--

84
Page

Waits River Formation -...- 33, 35, 39, 43, 44,

52,97

Walloomsac Formation

Warner Mountain _......-....... 8

Waterbury dome -.... 94

Williamsburg Granodiorite _..._... 61,67

Windsor quadrangle -

Woronoco dome

Woronoco fold -

Woronoco quadrangle

*U.S. GOVERNMENT PRINTING OFFICE: $19750-585-476 / 150-$ 
